Klaus Beuermann ( $\mathrm{Hg}$.

\title{
Grundsätze über die Anlage neuer Sternwarten
} mit Beziehung auf die Sternwarte der Universität Göttingen

von

Georg Heinrich Borheck

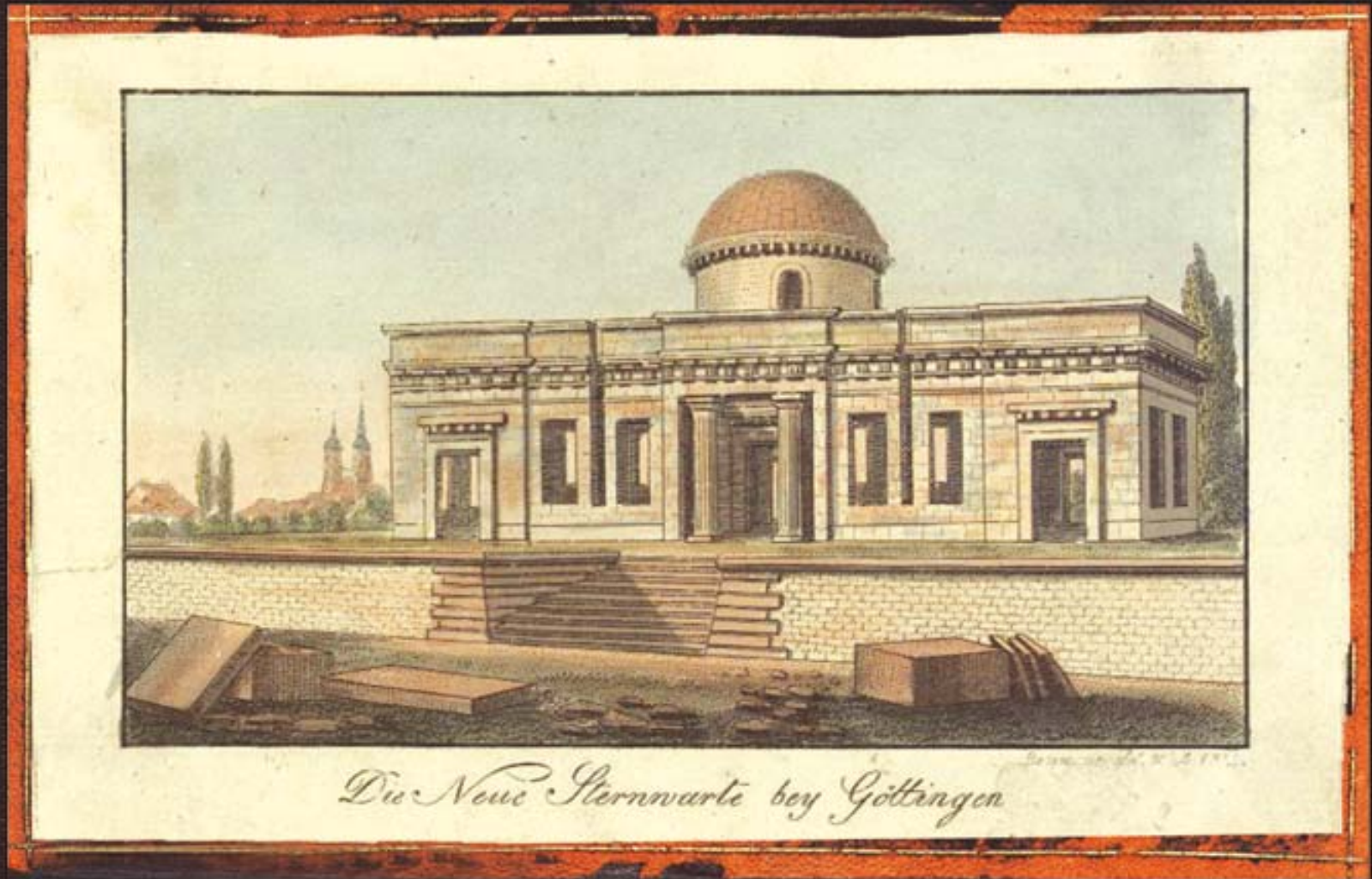

Q⿻弋一 Universitätsverlag Göttingen 

Klaus Beuermann (Hg.)

Grundsätze über die Anlage neuer Sternwarten

Georg Heinrich Borheck

This work is licensed under the

Creative Commons License 2.0 "by-nd", allowing you to download, distribute and print the document in a few copies for private or educational use, given that the document stays unchanged and the creator is mentioned. You are not allowed to sell copies of the free version.

SORMERIGHIS RESERVED 
erschienen im Universitätsverlag Göttingen 2005 
Klaus Beuermann (Hg.)

Grundsätze über die Anlage neuer Sternwarten

unter Beziehung auf die

Sternwarte der Universität

Göttingen

von Georg Heinrich

Borheck

Mit einem Geleitwort des

Präsidenten

der Georg-August-Universität

Göttingen, Kurt von Figura

und Beiträgen von David Aubin, Klaus Beuermann,

Robert Förster, Christian Freigang und Nicolaas Rupke

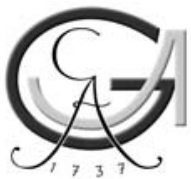

Universitätsverlag Göttingen 2005 
Bibliographische Information der Deutschen Nationalbibliothek

Die Deutsche Nationalbibliothek verzeichnet diese Publikation in der Deutschen Nationalbibliographie; detaillierte bibliographische Daten sind im Internet über $<$ http://dnb.ddb.de> abrufbar.

Dieses Buch ist auch als freie Onlineversion über die Homepage des Verlags sowie über den OPAC der Niedersächsischen Staats- und Universitätsbibliothek (http://www.sub.uni-goettingen.de) erreichbar und darf gelesen, heruntergeladen sowie als Privatkopie ausgedruckt werden. Es gelten die Lizenzbestimmungen der

Onlineversion. Es ist nicht gestattet, Kopien oder gedruckte Fassungen der freien Onlineversion zu veräußern.

(C) Universitätsverlag Göttingen 2005

Bearbeitet von der Niedersächsischen Staats- und Universitätsbibliothek Göttingen Abbildungsnachweis:

Universitäts-Sternwarte Göttingen: 6, 7, 8, 10, 15, 16, 20, 21, 22, 24, 26, 27, 28, 29, 30, 31, 32, 33, 34 .

K. Reinsch, Universitäts-Sternwarte: 1, 9, 11, 12, 13, 25.

R. Förster: 17, 18, 19.

Niedersächsische Staats- und Universitätsbibliothek Göttingen: 4, 5, 23.

Privatbesitz: 2, 3, 14.

Digitalisierungen: Göttinger Digitalisierungszentrum an der

Niedersächsischen Staats- und Universitätsbibliothek Göttingen

Umschlaggestaltung: Margo Bargheer

Satz und Layout: Universitätsverlag Göttingen

ISBN 3-938616-02-4 


\section{Inhaltsverzeichnis}

Kurt von Figura

Geleitwort des Präsidenten

Klaus Beuermann

Vorwort 9

Klaus Beuermann

Vorgeschichte und Odyssee des Borheckschen Manuskripts

Christian Freigang

Architekturhistorische Bemerkungen zur Göttinger Sternwarte

Nicolaas Rupke

Naturwissenschaftsarchitektur in der Historiographie der Naturwissenschaften

David Aubin

Astronomical Precision in the Laboratory:

The Role of Observatory Techniques in the History of the Physical Sciences

Klaus Beuermann

Carl Friedrich Gauß und die Göttinger Sternwarte

Robert Förster

Die Sternwarte zu Göttingen im Wandel der Zeiten

Umbauten und Restaurierungen

Georg Heinrich Borbeck

Grundsätze über die Anlage neuer Sternwarten

mit Beziehung auf die Sternwarte der Universität Göttingen 51

Vorrede 53

Erster Abschnitt 57

Zweiter Abschnitt 61

Dritter Abschnitt 86

Nachschrift 99

Zeittafel zu Georg Heinrich Borheck und zu politischen Ereignissen seiner Zeit 101

Kurzbiografien 


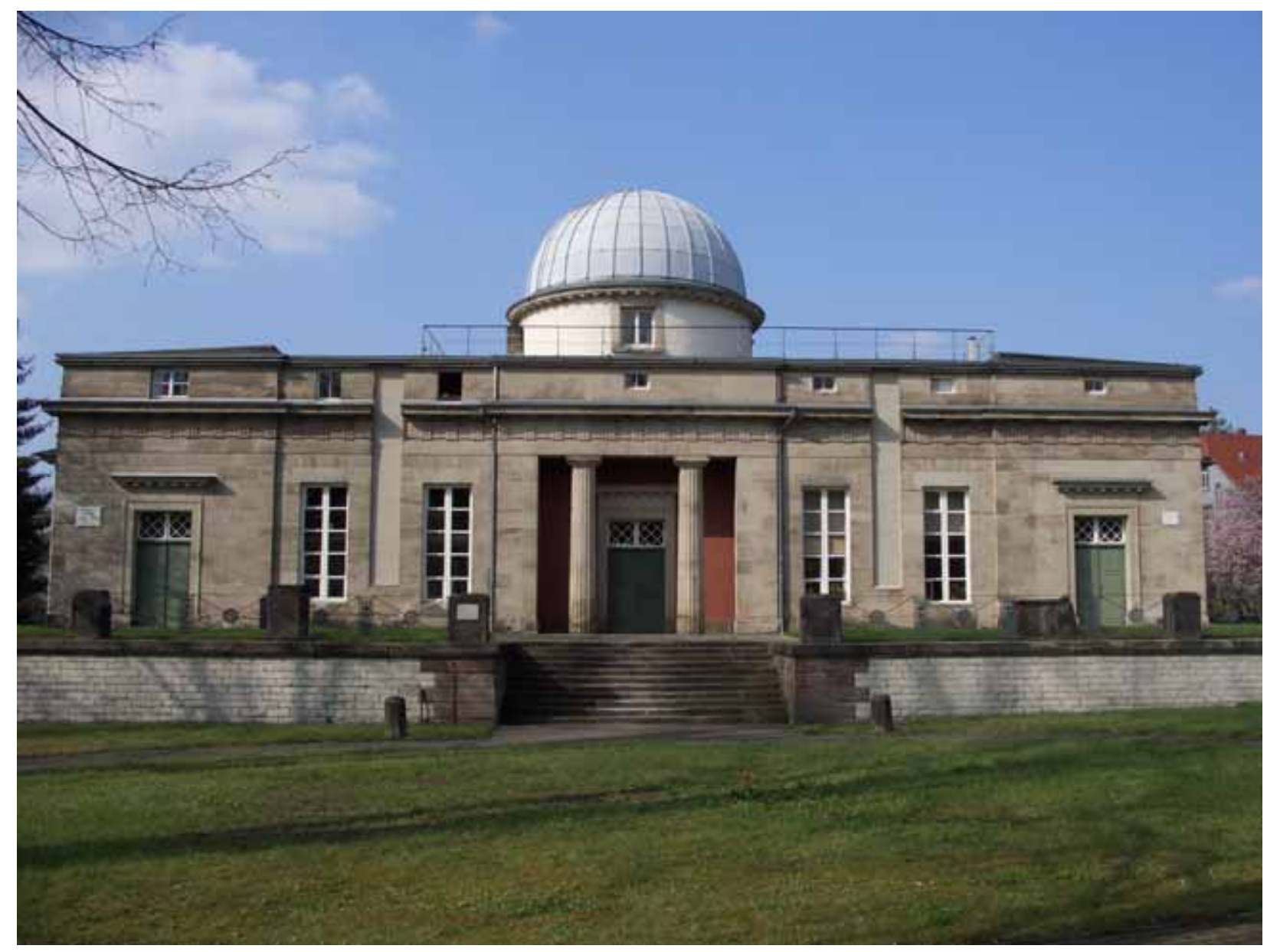

Abb. 1: Universitäts-Sternwarte Göttingen. Blick von Süden (Photo K. Reinsch 2004, Universitäts-Sternwarte) 


\section{Geleitwort des Präsidenten der Georg-August-Universität Göttingen}

Das Jahr 2005 ist für die Universität Göttingen und die Universitäts-Sternwarte in mehrfacher Hinsicht bedeutsam. Zum einen feiert die Universität das Gaußjahr zu Ehren des 150. Todestages dieses Universalgelehrten, der nahezu 50 Jahre lang das Amt des Direktors der Göttinger Sternwarte bekleidete. Zugleich verlässt die Astrophysik diesen traditionsreichen Wirkungsort in der Sternwarte und zieht in ein neues Gebäude in den Nordbereich der Universität um, in dem zum ersten Male alle physikalischen Institute eine gemeinsame Heimstatt erhalten. Schließlich beendete der damalige Universitäts-Baumeister Georg Heinrich Borheck (1751-1834) im Jahre 1805 seine Schrift „Grundsätze über die Anlage neuer Sternwarten mit Beziehung auf die Sternwarte der Universität Göttingen“, in der er die Architektur dieses bedeutenden Baus beschreibt. Die angestrebte Veröffentlichung des bedeutenden Traktats konnte wegen der Kriegswirren und politischen Umwälzungen der Napoleonischen Zeit nicht realisiert werden und wird nach 200 Jahren in diesem Jubiläumsjahr nachgeholt.

Die in den Jahren 1803-1816 vor dem Geismartor errichtete Universitäts-Sternwarte setzt mit ihrer an höchsten wissenschaftlichen Ansprüchen orientierten Architektur einen Maßstab, der sie deutlich von früheren Sternwartenbauten abhebt. Die Konsequenz mit der hier die Bedingungen für die allerbesten Beobachtungsmöglichkeiten geschaffen wurden ist für die damalige
Zeit neu und blieb richtungsweisend für das spätere 19. Jahrhundert. Zum ersten Male wurden beim Entwurf dieser Sternwarte Aspekte wie die erschütterungsfreie Aufstellung von Instrumenten durch vom übrigen Bau getrennte solide Fundamente, Vermeidung von störenden Luftbewegungen, sowie hohe Bequemlichkeit und damit effektive Durchführung der Beobachtungen von vornherein konsequent bedacht und auch gegen einschränkende ökonomische Begrenzungen erfolgreich durchgesetzt. Über lange Strecken liest sich Borhecks Traktat wie ein Plädoyer für ein Abweichen von der sicher auch in damaliger Zeit in gewisser Weise existierenden öffentlichen Bauordnung.

Mit dem Umzug der Astrophysik zu den anderen physikalischen Instituten in den Nordbereich wird die Sternwarte nun einer neuen Bestimmung zugeführt. Die Universität plant umfassende Renovierungsarbeiten, die den Haupttrakt, Seitenflügel und das Nebengebäude der Anlage einschließen. Nach Abschluss der Arbeiten werden die historischen Räume des Sternwartegebäudes für Sonderveranstaltungen und besondere Lehrveranstaltungen zur Verfügung stehen und für eine historische, an Gauß erinnernde Ausstellung genutzt werden. Als Präsident der Universität freue ich mich, dass hierdurch zukünftig die einmalige Chance gegeben ist, Teile des für Göttingen und die Universität so bedeutenden Gebäudes auch für ein breites Publikum zu öffnen.

Göttingen, im Dezember 2004

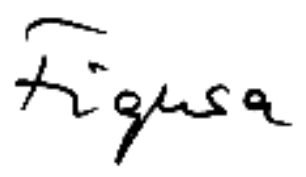

Prof. Dr. Dr. h. c. Kurt von Figura 


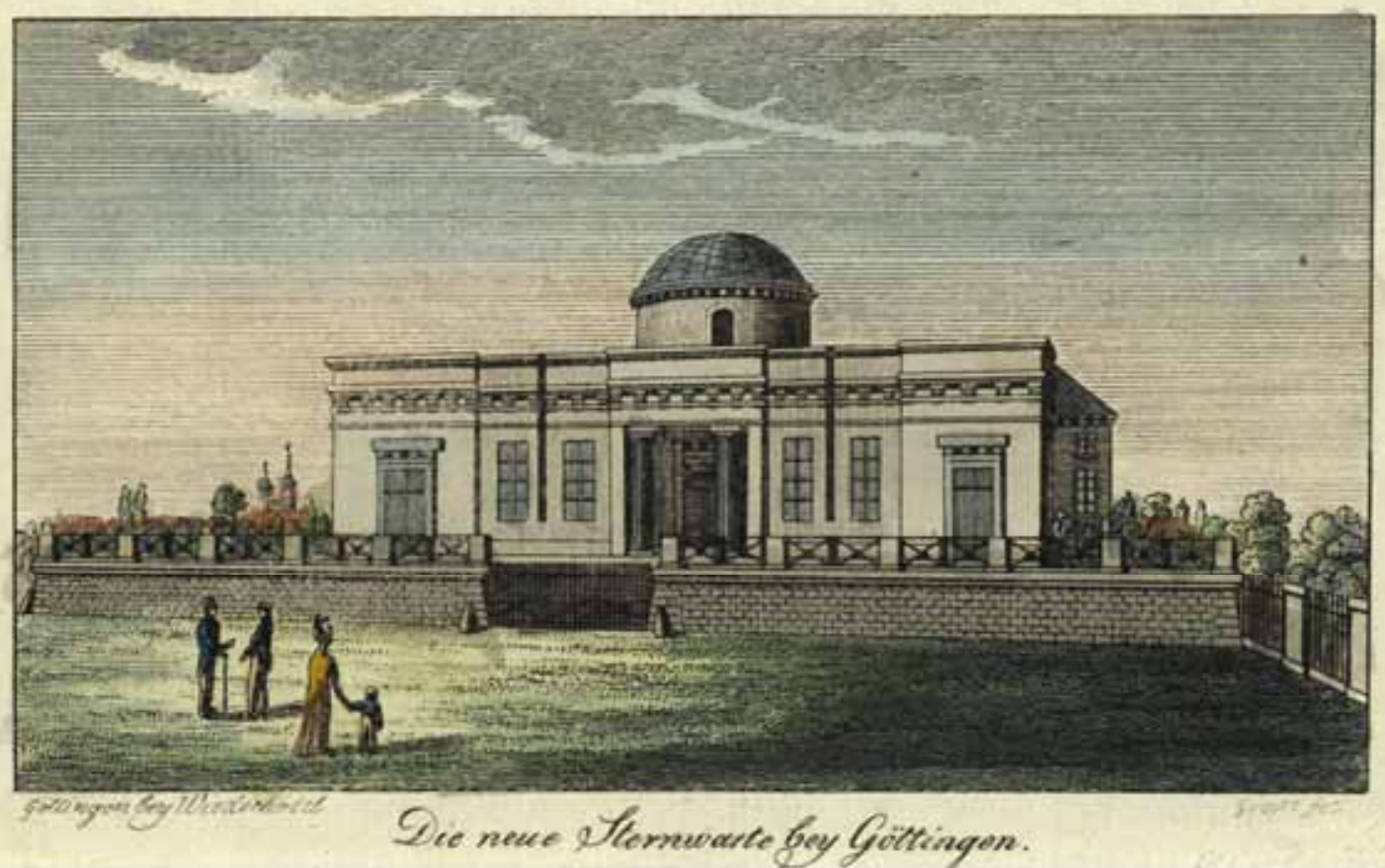

Abb. 2: Die neue Sternwarte bey Göttingen ; Stammbuchblatt verlegt bei Wiederhold, Sign. Grape fec., Besitzer Frederic Hessman.

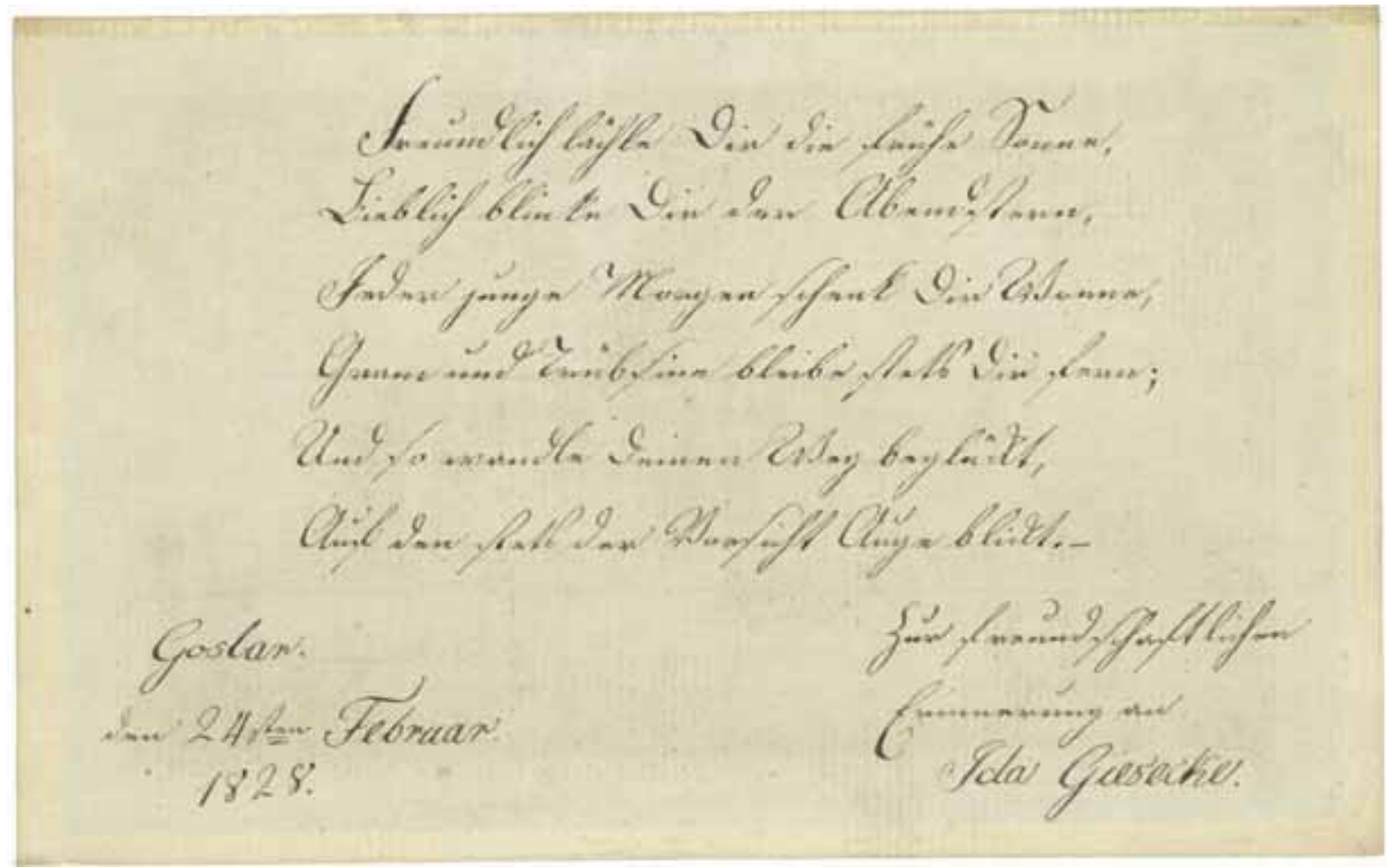

Abb. 3: Private Widmung auf der Rückseite des o.a. Stammbuchblattes vom 24. Februar 1828 : „Freundlich lächle Dir die frühe Sonne, Lieblich blinke Dir der Abendstern, .....“ 


\section{Vorwort}

Die Göttinger Universitäts-Sternwarte hat durch ihre bedeutenden Direktoren, darunter Carl Friedrich Gauß und Karl Schwarzschild, als Institution Weltgeltung gewonnen. Als Bauwerk ist sie ein nationales und europäisches Denkmal ersten Ranges, das zum Zeitpunkt seiner Entstehung vor 200 Jahren bereits aufgrund seiner richtungsweisenden Konstruktion große Bedeutung besaß. Der Bauentwurf wurde von dem Göttinger Universitätsbaumeister Georg Heinrich Borheck in seinem Manuskript „Grundsätze über die Anlage neuer Sternwarten mit Beziehung auf die Sternwarte der Universität Göttingen" beschrieben, das bis heute in der Universitäts-Sternwarte verwahrt wird.

Borhecks Manuskript ist in zweierlei Hinsicht ungewöhnlich. Zum einen ist das in feiner Sütterlin-Schrift verfertigte und 1805 datierte Manuskript ein Unikat. Zum anderen ist eine so detaillierte Beschreibung der architektonischen Konzeption, der technischen Konstruktion sowie der Begründung der Erstausstattung an Teleskopen und sonstigen Messgeräten für ältere Sternwarten selten. Borhecks Text bezieht sich im Titel ausdrücklich auf Göttingen, doch sind die meisten seiner Argumente allgemeiner Natur und können mit Recht auf jeden Sternwartenbau um 1800 bezogen werden. Die von Borheck 1805 angestrebte Publikation war deshalb sinnvoll, scheiterte aber an den kriegerischen Zeiten und an absonderlichen Zufälligkeiten. Die Historie dieses Vorhabens wirkt in manchen Aspekten wie eine Kriminalgeschichte mit diversen Verschleierungen.

Auch nach 200 Jahren bleibt Borhecks Manuskript ein bedeutendes Dokument, das hier zum ersten Male der Öffentlichkeit zugänglich gemacht wird. Zur Seite gestellt werden der Transkription des Originaltextes und dem Ab- druck der prächtigen Farbtafeln eine Einführung in Borhecks Werk und fünf Abhandlungen zur architekturgeschichtlichen Einordnung der Göttinger Sternwarte, $\mathrm{zu}$ wissenschaftshistorischen Aspekten, zur Baugeschichte sowie der geplanten Rekonstruktion ihres Hauptgebäudes und zu Carl Friedrich Gauß’ Wirken in der Sternwarte.

Ausgehend von einer früheren Transkription Horst Michlings wurden Fehler beseitigt und eine völlig neue digitalisierte Textversion erstellt. Dabei wurde die zeitgenössische Orthografie - auch bei unterschiedlicher Schreibweise des gleichen Wortes - sowie die etwas gewöhnungsbedürftige Zeichensetzung beibehalten. Einige von Borheck in lateinischen Buchstaben eingefügte Worte wurden dem Original entsprechend hervorgehoben und Zitate, insbesondere die gutachterlichen Äußerungen des Gothaer Astronomen Freiherr von Zach, kursiv gesetzt.

Mein Dank als Herausgeber gilt in erster Linie den beteiligten Einrichtungen der Universität, die eine Veröffentlichung dieser Schrift zum 200. Jahrestag ihrer Entstehung im Gaußjahr 2005 ermöglicht haben. Sie setzen damit anlässlich des Umzugs der Astrophysik in den Neubau der Physikalischen Institute und anlässlich des bevorstehenden Wechsels in der Nutzung der Sternwarte ein Zeichen, das die besondere Bedeutung dieses Baus hervorhebt. Großen Dank schulde ich auch der Niedersächsischen Staats- und Universitätsbibliothek, die sich mit ihrem Verlag und den an der Herstellung der Abbildungen beteiligten Personen diesem Vorhaben mit großem Engagement gewidmet hat, insbesondere Margo Bargheer und Martin Liebetruth. Schließlich danke ich allen Kollegen, die mir mit Informationen geholfen haben, insbesondere Axel Wittmann und Hartmut Grosser. Patrick Hessman danke ich für die Herstellung der elektronischen Version des Borheckschen Manuskripts und meiner Frau Ingrid für ihr Verständnis angesichts langer mit der Edition verbrachter Abende.

Göttingen, im Januar 2005 Klaus Beuermann 


\section{Vorgeschichte und Odyssee des Borheckschen Manuskripts}

\author{
von Klaus Beuermann, Göttingen
}

Der Bau der Göttinger Sternwarte erfolgte vor dem Hintergrund astronomischer Entdeckungen gegen Ende des 18. Jahrhunderts, die das Weltbild veränderten und die Stellung der Astronomie als Naturwissenschaft stärkten. Zunehmende Bedeutung erlangte die Astronomie im 18. Jahrhundert auch im Vermessungswesen zu Lande und auf See, einem besonderen Anliegen der staatlichen Verwaltungen. In Frankreich und in Großbritannien waren vor diesem Hintergrund bereits ein Jahrhundert früher das Observatoire de Paris (1667) bzw. das Royal Greenwich Observatory (1675) gegründet worden. In Deutschland existierte selbst um 1800 noch keine von einem Landesherrn für öffentliche Aufgaben erstellte und als solche entworfene größere Sternwarte. Der für Göttingen zuständige Landesherr und gleichzeitig der Rector magnificentissimus der Göttinger Universität war seit 1760 König Georg III, in Personalunion Kurfürst von Hannover, Enkel und Nachfolger von Georg II (Georg August), dem Gründer der Göttinger Universität. Er war der Adressat für die Bemühungen der Universität Göttingen, eine den Anforderungen der Zeit entsprechende Sternwarte zu errichten.

Drei im späten 18. Jahrhundert errichtete Sternwarten sind baugeschichtlich bedeutsam, die von Dr. John Radcliffe privat finanzierte Sternwarte in Oxford/England (1772-1778), das Dunsink Observatory des Trinity College in Dublin/Irland (1783-1785) und die private Sternwarte des Herzogs von Sachsen Gotha und Altenburg auf dem Seeberg bei Gotha (17871789). Die Sternwarte in Oxford erhielt als erste zwei ebenerdige Meridiansäle - neben einem noch recht unzweckmäßig konzipierten, an antikem Vorbild orientierten, zentralen Turm.

In Göttingen war 1762 Tobias Mayer gestorben, der Direktor der ersten, noch kleinen Göttinger Sternwarte auf einem Turm der alten Stadtmauer. Diese alte Sternwarte wurde anschlieBend von den Mathematikern Lowitz und Kästner verwaltet, bis 1789 Karl Felix von Seyffer als a.o. Professor für Astronomie berufen wurde ${ }^{1}$. Auch ohne hauptamtlichen Astronomen setzte sich die Universität, wohl auch unter dem Einfluss von Lichtenberg, für die Astronomie ein und erweiterte das Inventar um bedeutende Instrumente, wie damals üblich, meist in Form königlicher Geschenke. So ist das große Spiegelteleskop von Herschel an die alte Sternwarte gekommen, das dieser im Juli 1786 selbst aufbaute $^{2}$. Zu Seyffers Zeit wurde 1791 erstmals der Antrag auf den dringend erforderlichen Ersatz der unzulänglichen Sternwarte auf der Stadtmauer durch einen adäquaten, dem wissenschaftlichen und technischen Stand entsprechenden Neubau gestellt und in den Folgejahren wiederholt, bis schließlich 1802 König Georg III die Summe von 22680 Talern für den Neubau bewilligte ${ }^{1}$.

Mit dem Entwurf und Bau der neuen königlichen Sternwarte in Göttingen wurde der Universitäts-Baumeister Georg Heinrich Borheck (1751-1834) betraut. Borheck nahm die neue Aufgabe zum Anlass, sich intensiv mit dem Sternwartenbau zu beschäftigen und insbesondere zu klären, worin die Mängel bisheriger Bauwerke bestünden und welche Anforderungen von fachastronomischer Seite an ein ideales, auf dem neuesten Stand der Architektur und Technik stehendes Gebäude zu stellen seien. Er konnte sich dabei auf ausführliche Gutachten von zwei namhaften Experten stützen, Justizrat Hieronymus Schröter (1745-1816), der die private Sternwarte in Lilienthal bei Bremen betrieb, und Franz Xaver von Zach (1754-1832), dem Direktor der Seeberger Sternwarte.

\footnotetext{
1 H.-H. Vogt, Geschichte der Göttinger Sternwarte, GEORGIA AUGUSTA, Mai 1992

${ }^{2}$ H. Grosser, Historische Gegenstände an der UniversitätsSternwarte Göttingen, Ein Katalog zum 250-jährigen Bestehen der Sternwarte, herausgegeben von der Akademie der Wissenschaften zu Göttingen, Kommission für historische Apparate.
} 


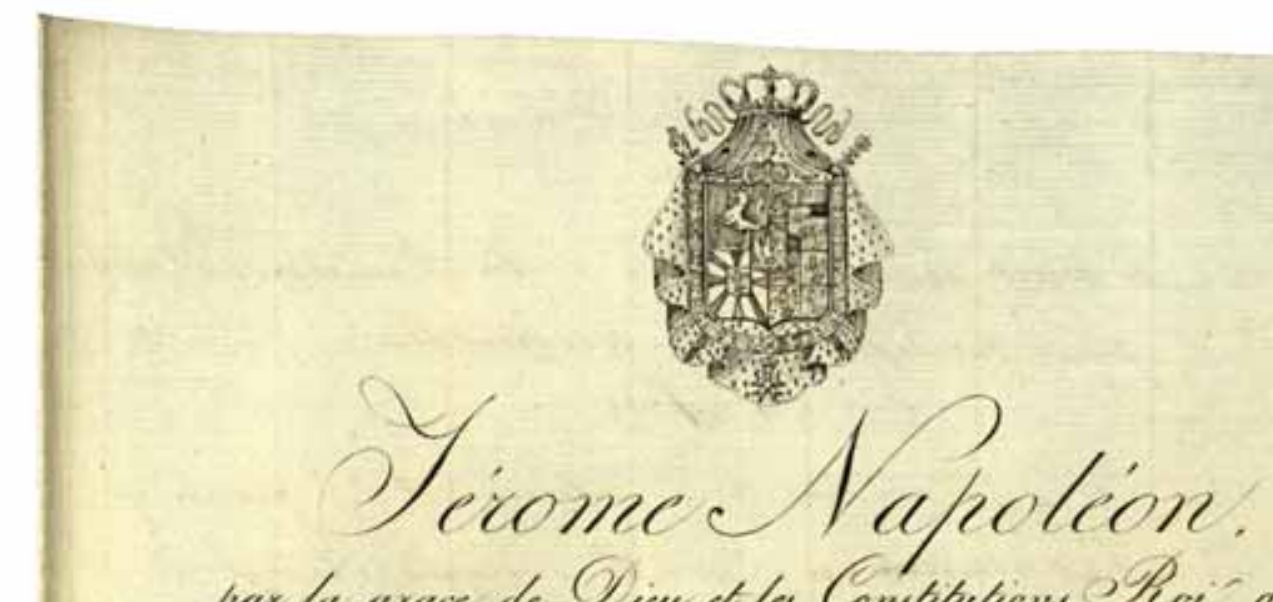

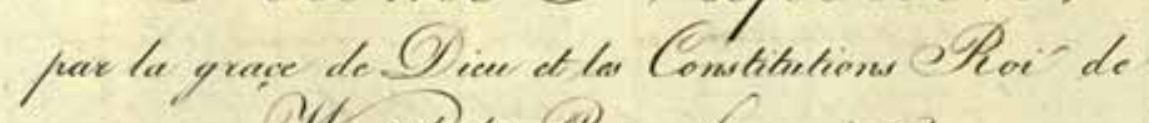

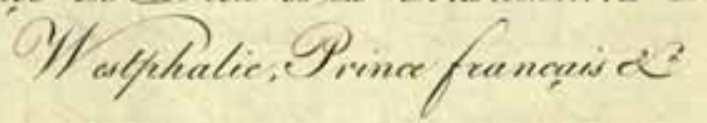

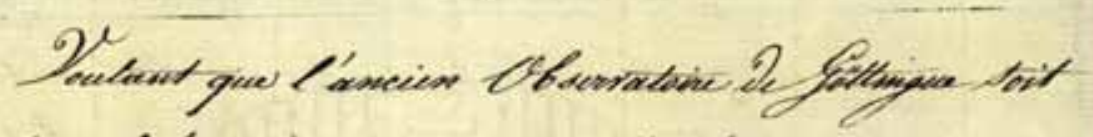

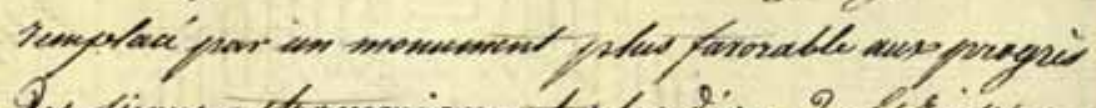

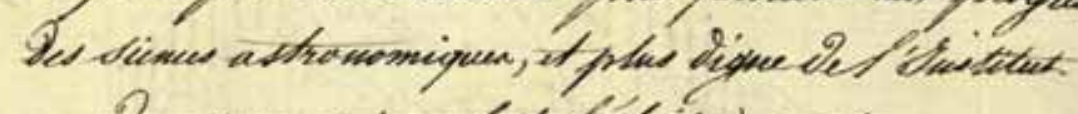

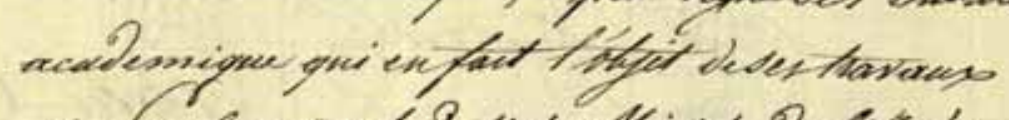

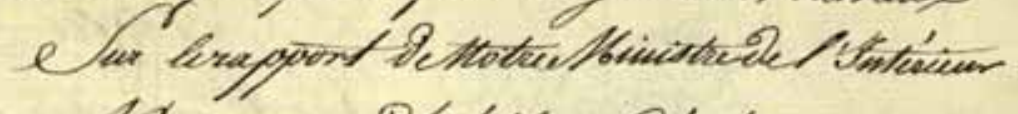

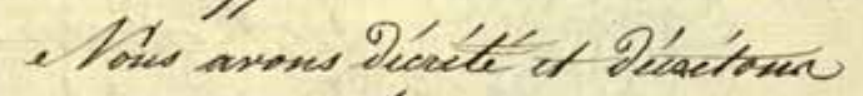

Io elyt

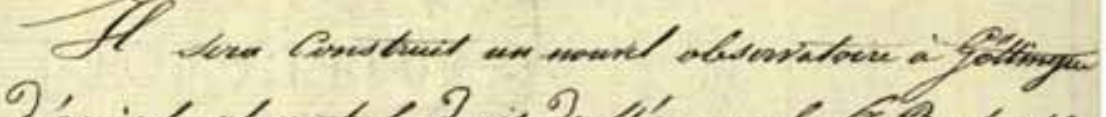

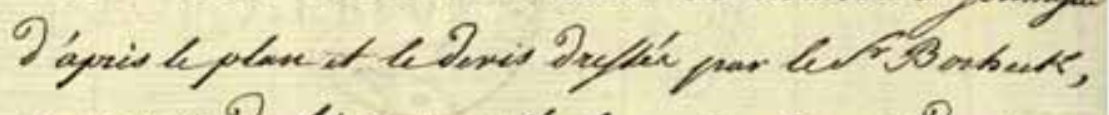

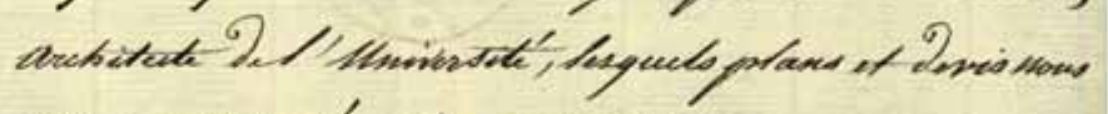

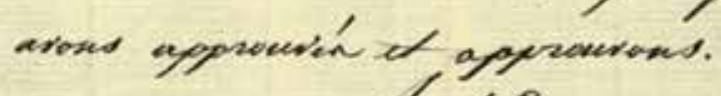

c 6ot:o

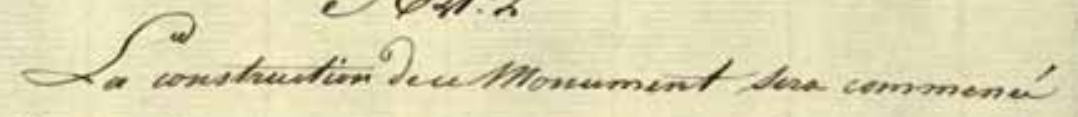

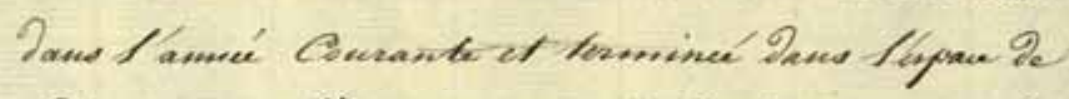

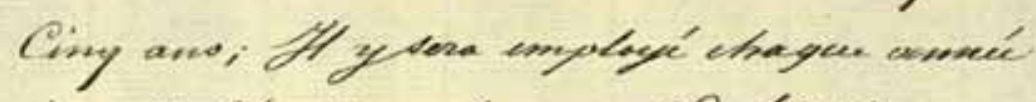

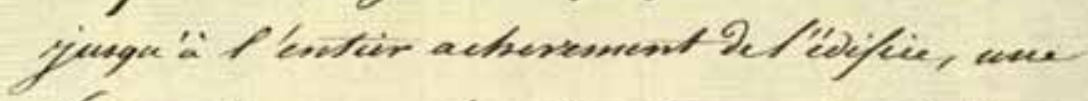

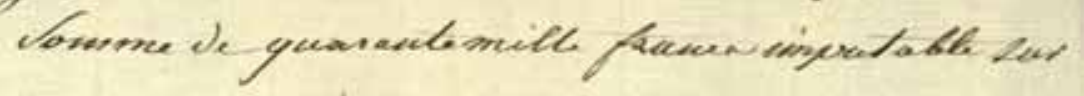

600.26 


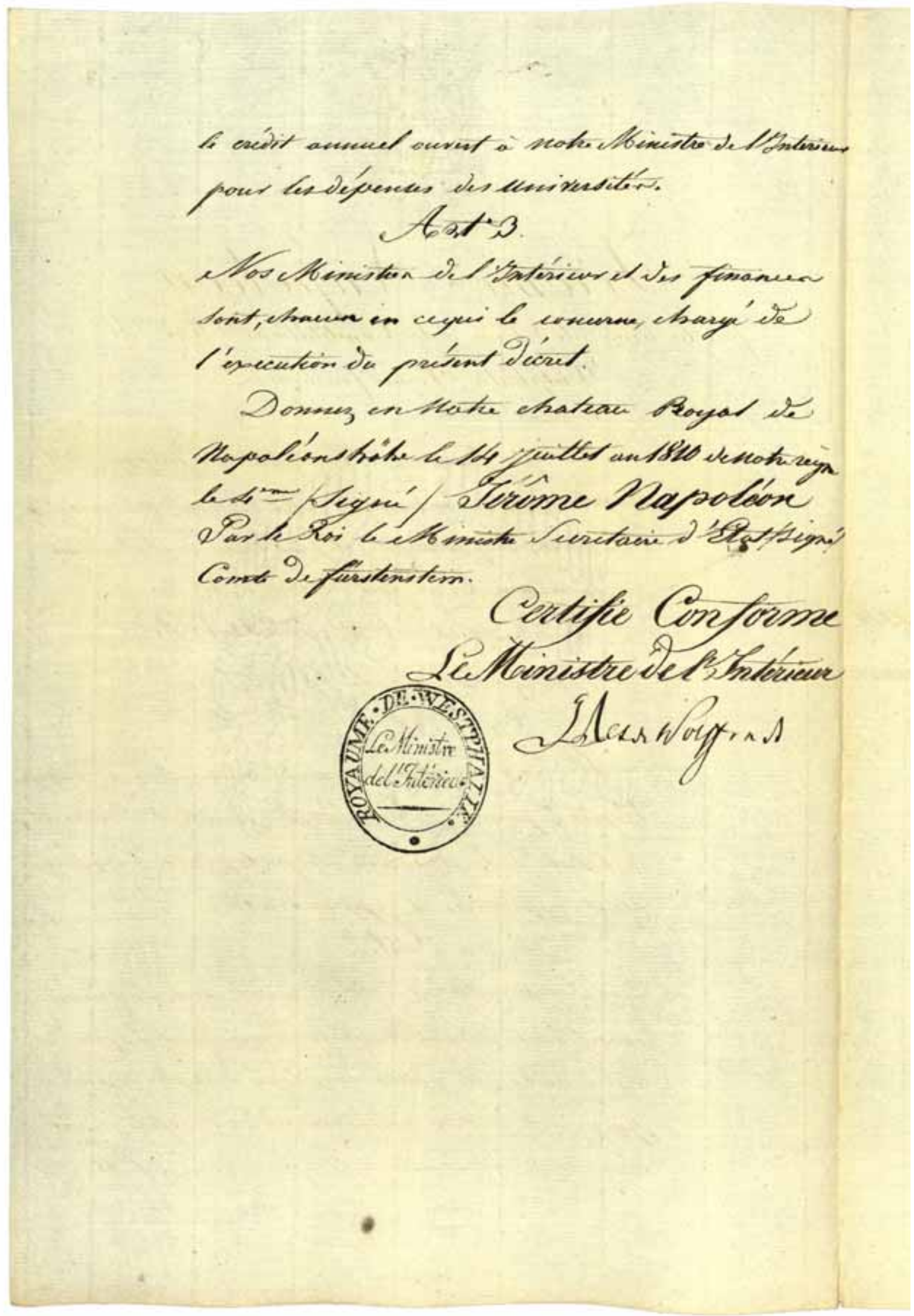

Abb. 4: Vorherige und diese Seite: Faksimile des Edikts von König Jérôme Bonaparte vom 14. Juli 1810, in dem dieser den Weiterbau der Sternwarte nach dem Plan und Anschlag Borhecks befiehlt und 200.000 Francs als Bausumme verteilt über fünf Jahre bereitstellt. 
Franz Xaver von Zach kannte die Radcliffesche Sternwarte in Oxford aus eigener Anschauung und hatte im Auftrage des Gothaer Herzogs die erste nach rein wissenschaftlichen Gesichtspunkten konzipierte Sternwarte auf dem Kontinent errichtet. Dazu gehörten die ebenerdige Anlage und eine sorgfältige Fundamentierung der Instrumentenpfeiler unabhängig vom Gebäude, so dass schwere Instrumente installiert werden konnten und sich ihre Genauigkeit voll ausschöpfen ließ. Von der gesamten Investition von 56000 Talern wurden allein 20000 Taler für die instrumentelle Erstausstattung ausgegeben ${ }^{3}$. Aufbauend auf den Erfahrungen Schröters und Zachs gelang Borheck die Konzeption eines sehr fortschrittlichen Gebäudes, das die Fehler früherer Bauten weitgehend vermied. Durch den kriegsbedingten Baustopp war es Borheck nicht vergönnt, den Bau der Göttinger Sternwarte zu vollenden, und ein Jahrzehnt später, als der Bau wieder aufgenommen wurde, entsprach das äußere Erscheinungsbild seiner Konzeption nicht mehr dem Zeitgeschmack. Seine technische Konstruktion wurde jedoch beibehalten und so ein dauerhaftes und für lange Zeit vorbildliches Sternwartengebäude geschaffen. Auch bei der Umgestaltung 1887/88 wurde die grundlegende Konstruktion nicht verändert und erst Anfang des 20. Jahrhunderts, als sich unter dem Direktor Karl Schwarzschild der Übergang zur modernen Astrophysik anbahnte, war die auf die Positionsastronomie ausgerichtete technische Konzeption des Gebäudes nicht mehr zeitgemäß $3^{4}$. Trotzdem hat sich dieser Bau aufgrund des beträchtlichen Platzangebots bis heute bewährt. Die Göttinger Sternwarte ist die einzige verbleibende deutsche Sternwarte aus der Zeit vor 1870 und, nach Paris und Dublin, die drittälteste Sternwarte der Welt in originaler Nutzung ${ }^{5}$. In den folgenden Jahrzehnten des frühen 19. Jahrhunderts entstanden ähnliche Gebäude u.a. in Neapel (1820), Hamburg (1825, abgebrochen 1912), Kapstadt (1828), Helsinki (1834), Berlin (1835, abgebrochen 1915)

\footnotetext{
${ }^{3}$ M. Strumpf, Gothas astronomische Epoche, Geiger Verlag, 1998. - Nach Tod des Herzogs 1804 musste Franz Xaver von Zach andere Aufgaben am Hof übernehmen und unter dem neuen Herzog ließ die Unterstützung für die Seeberger Sternwarte nach, 1840 wurde sie aufgegeben und 1858 abgebrochen.

${ }^{4}$ Es wurden jedoch noch bis in das Jahr 1923 hinein Investitionen am Reichenbergschen Meridiankreis getätigt.

5 Dies gilt bis zum Umzug der Göttinger Astrophysik in den Physik-Neubau im Jahre 2005.
}

und Pulkowo/St. Petersburg (1839, im zweiten Weltkrieg zerstört und modernisiert wieder aufgebaut).

Borheck hat die sehr umfangreichen und detaillierten Überlegungen der Grundsätze, die bei der Anlage neuer Sternwarten zu bedenken sind, in seinem zweibändigen Werk niedergelegt, das 1805 veröffentlichungsreif war. Es besteht aus dem 135-seitigen Sütterlin-Manuskript und einem Band mit den sechs den Text ergänzenden Farbtafeln sowie sechs weiteren z.T. farbigen technischen Zeichnungen. Die Abbildungen geben sowohl einen ersten Entwurf von 1802 ohne Seitenflügel wieder, wie er wohl für einen zunächst ins Auge gefassten Standort auf dem Wall in Verlängerung der Nicolaistraße geplant war, als auch den zweiten stärker klassizistischen Entwurf von 1803, der zusätzlich die Wohntrakte enthält. Die Ähnlichkeit des zweiten Entwurfs mit der Gothaer Sternwarte ist unverkennbar. Die symmetrische Anlage des Baus mit zwei architektonisch gleich gestalteten Flügeln, jeweils bestehend aus Meridiansaal, Vorbereitungssaal und Wohntrakt, wurde mit den Ansprüchen sowohl von Seiten der Wissenschaft als auch der Lehre begründet. So sollten im Westflügel die qualitativ besten Instrumente für die fortgeschrittene Forschung stehen, während der Ostflügel der Lehre gewidmet und z.T. mit den noch sehr guten Instrumenten aus der alten Sternwarte eingerichtet werden sollte. Für die Ausbildung spielte die Astronomie nicht nur als reine, sondern auch als angewandte Wissenschaft eine Rolle, mit Bedeutung für die Geodäsie, die Kartographie und die Seefahrt. Diese Konzeption wird in Borhecks Schrift als einmalig in Deutschland - vielleicht in ganz Europa - bezeichnet ${ }^{6}$. Dabei wurde als Grundsatz akzeptiert, dass die vorgesehene Vereinigung von Lehr- und Forschungsaufgaben „nur sebr unvollkommen erreicht würde, wenn die Sternwarte von den übrigen akademischen Lebranstalten beträchtlich entfernt wäre ${ }^{67}$, was z.B. gegen den ebenfalls diskutierten Standort auf dem Hainberg sprach. Der Bau der beiden Wohntrakte, einer für den Direktor und der an-

\footnotetext{
6 Die zwei Meridianinstrumente der Seeberger Sternwarte dienten nur der Forschung und die Adaption dieser Konstruktion wurde in Göttingen anders begründet. Georg III und später Jérôme Bonaparte unterstützten die vorgeschlagene aufwändige Konzeption jedoch offenbar ohne Vorbehalte.

7 Dieses und das folgende Zitat entstammen dem in diesem Band abgedruckten Text Borhecks.
} 
dere für einen zweiten einzustellenden Beobachter, wurde mit der enorm erhöhten Funktionalität begründet, denn „wenn eine Sternwarte ganz ibren Zweck erfüllen und nicht blos des Nabmens oder der Zierde wegen dastehen soll, so muß mit derselben die Wohnung des Observators ..... in unmittelbare Verbindung gesetzt ..... seyn ..... denn es treten bei Tage und des Nachts unzäblbare Fälle ein, da der Beobachter angenblicklich seine übrigen Geschäfte unterbrechen und zu den Instrumenten eilen muß.“

Die von Borheck übernommenen Empfehlungen Zachs enthalten eine lange Liste der erforderlichen Instrumente bester Provenienz und deren Kosten. Addiert man die Einzelpositionen auf, so kommt man für die instrumentelle Erstausstattung auf die erstaunliche Summe von mehr als 2000 Guineas $^{8}$, was einem Äquivalent von 15000 Talern oder 2/3 der ursprünglich bewilligten Bausumme entspricht. Die Gesamtsumme der später wirklich durchgeführten Beschaffungen, die Bedeutung dieser Instrumente im realen Beobachtungsbetrieb und die Finanzierungsmodi ${ }^{9}$ bei ihrer Beschaffung wären einer besonderen Untersuchung wert. Der Gesamtaufwand dürfte beträchtlich gewesen sein ${ }^{10}$. Tatsächlich beließ es Gauß nicht bei der Anschaffung eines Meridiankreises („ganzen Kreises"), wie von Zach und Borheck vorgeschlagen sondern beschaffte sinnvollerweise deren zwei, 1818 den Repsoldschen Kreis aus Hamburg für den Ostflügel (Abb. 24) und 1819 den sehr genauen Reichenbachschen Kreis für den Westflügel. Mit dem Repsoldschen Kreis hat Harding seine Beobachtungen für den Atlas novus coelestis von 1822 gemacht. Der Reichenbachsche Kreis wurde von Gauß u.a. für die Landesvermessung eingesetzt und war für ein Jahrhundert das Hauptinstrument der Sternwarte ${ }^{11}$. Borheck war sich bei der Abfassung seiner Schrift der Bedeutung der instrumentellen Ausstattung und der

81 Guinea $=21 / 20$ Pfund Sterling entsprach etwa 7 Talern, 1 Pistole (spanische Goldmünze) entsprach etwa 5 Talern und 1 Taler $=3$ Mark der deutschen Goldwährung.

9 Viele der kostspieligen Instrumente waren Geschenke des Königs oder von Mitgliedern der königlichen Familie.

10 Siehe hierzu auch die Ausführungen von David Aubin in diesem Band.

$11 \mathrm{Zu}$ seiner exakten Ausrichtung wurden $12 \mathrm{~km}$ südlich der Sternwarte auf dem Steinkopf bei Friedland das noch existierende Meridianzeichen und ein entsprechendes abgeganges im Norden errichtet. In der Entfernung des Friedländer Zeichens entspricht die Genauigkeit des Reichenbergschen Kreises von besser als 1 Bogensekunde einer seitlichen Verschiebung von wenigen Zentimetern. Durch Mittelung vieler Messungen ist damit die Lage des Nullpunkts der hannoverschen Landesvermessung sehr genau bestimmt.
Tatsache, dass diese einen wesentlichen Prozentsatz der Bausumme ausmachen würde, zweifellos bewusst und hat diese Kostenaufstellung überzeugend in seine „Grundsätze“ eingeschlossen. Zum Vergleich seien die Erstausstattungsmittel für den Neubau der physikalischen Institute der Universität Göttingen (2002 - 2005) genannt. Sie liegen bei 30\% der Baukosten. Sowohl die Göttinger als auch vorher die Gothaer Sternwarte wurden also vergleichsweise sehr gut mit Instrumenten ausgestattet.

Auf der Grundlage des Befehls Georgs III wurde der Bau der Sternwarte, wie Borheck in seiner Vorrede berichtet, im Frühjahr 1803 begonnen. Wegen der erneuten kriegerischen Auseinandersetzungen wurden jedoch 1804 alle königlichen Bauten eingestellt. $\mathrm{Zu}$ diesem Zeitpunkt war der Bau bis zu einer Höhe der Grundmauern von 6 Fuß über dem gewachsenen Grund und damit bis zur Terrassenhöhe gediehen. Borheck zog sich zurück und konzentrierte sich auf die Vorbereitung seines Manuskripts zur Veröffentlichung.

An der Göttinger Universität gingen die geplanten Berufungen weiter voran. Im Vorgriff auf die neuen Arbeitsmöglichkeiten wurde 1805 Ludwig Harding, der 1804 in Lilienthal den dritten Planetoiden Juno ${ }^{12}$ entdeckt hatte, als a.o. Professor und Inspektor an die Sternwarte berufen. Carl Friedrich Gauß, der durch seine Bahnberechung des 1801 von Giuseppe Piazzi entdeckten ersten Planetoiden Ceres Weltruhm erlangt hatte ${ }^{13}$, folgte 1807 als o. Professor und Direktor der Sternwarte. Diese Berufungen erfolgten vor dem Hintergrund der neuen Entwicklungen auf dem Gebiet der Kosmogonie. Seit babylonischen Zeiten kannte man sieben sich bewegende Himmelskörper in einem anscheinend keinen Änderungen unterworfenen $\mathrm{Kosmos}^{14}$.

12 Der zweite Planetoid Pallas wurde 1802 von Olbers (1758-1840) in Bremen entdeckt.

13 Piazzis Beobachtungen vom 1.1.-11.2.1801 wurden im Septemberheft der von Zach im Jahre 1800 gegründeten Fachzeitschrift Monatliche Correspondenz veröffentlicht und bereits im Dezemberheft wurde die Berechnung der Bahn durch Gauß mitgeteilt, die ihm mit seiner Methode der kleinsten Quadrate gelang. Vergleichbar schnell publizierte später Karl Schwarzschild, ein anderer Direktor der Göttinger Sternwarte, die allgemeine Lösung der Bewegung eines Körpers in der Umgebung eines nichtrotierenden schwarzen Lochs nur wenige Monate nach Bekanntwerden der Einsteinschen allgemeinen Relativitätstheorie im Jahre 1915. 14 Sonne, Mond, Merkur, Venus, Mars, Jupiter und Saturn, die Namenspaten der sieben Wochentage. 


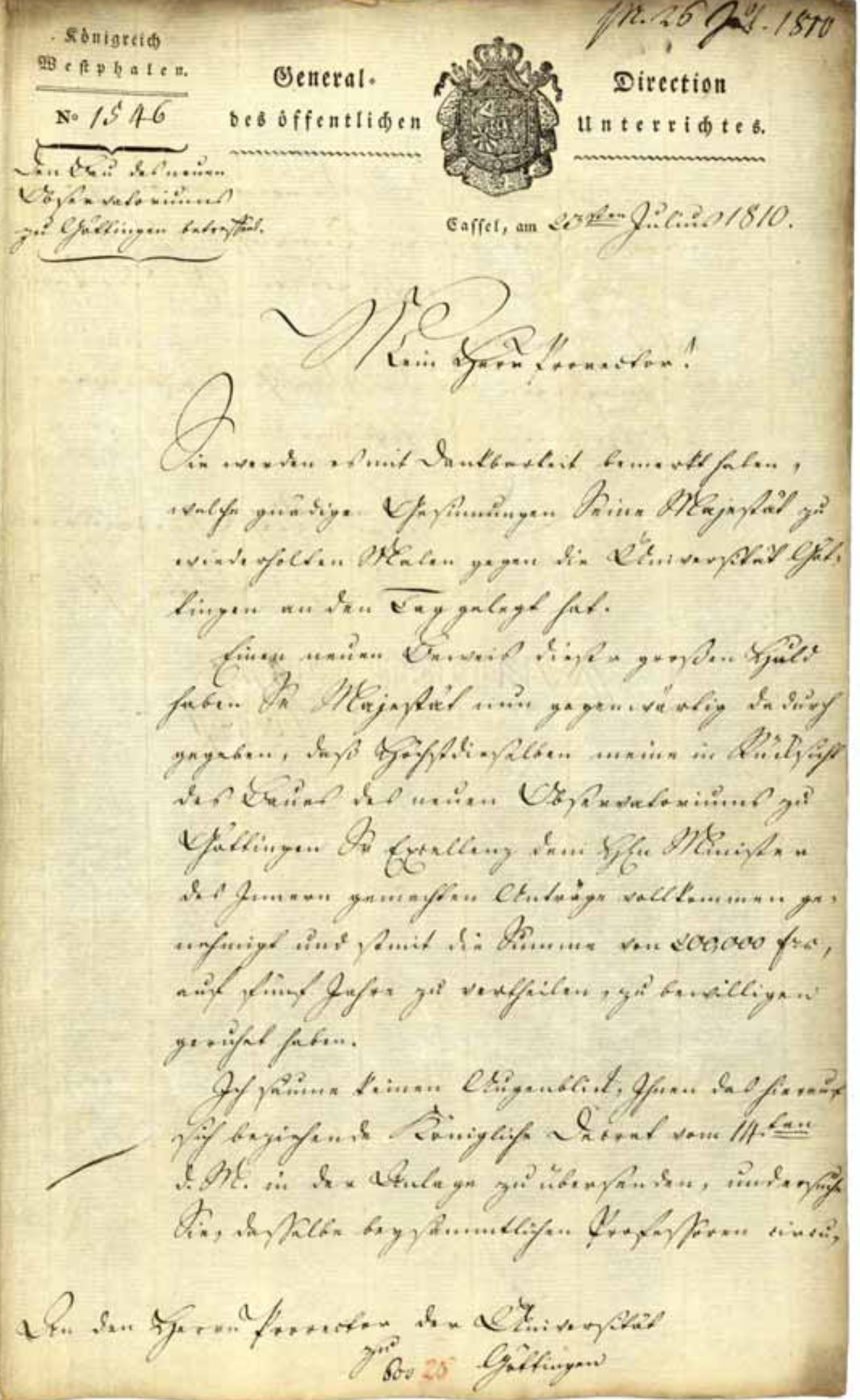




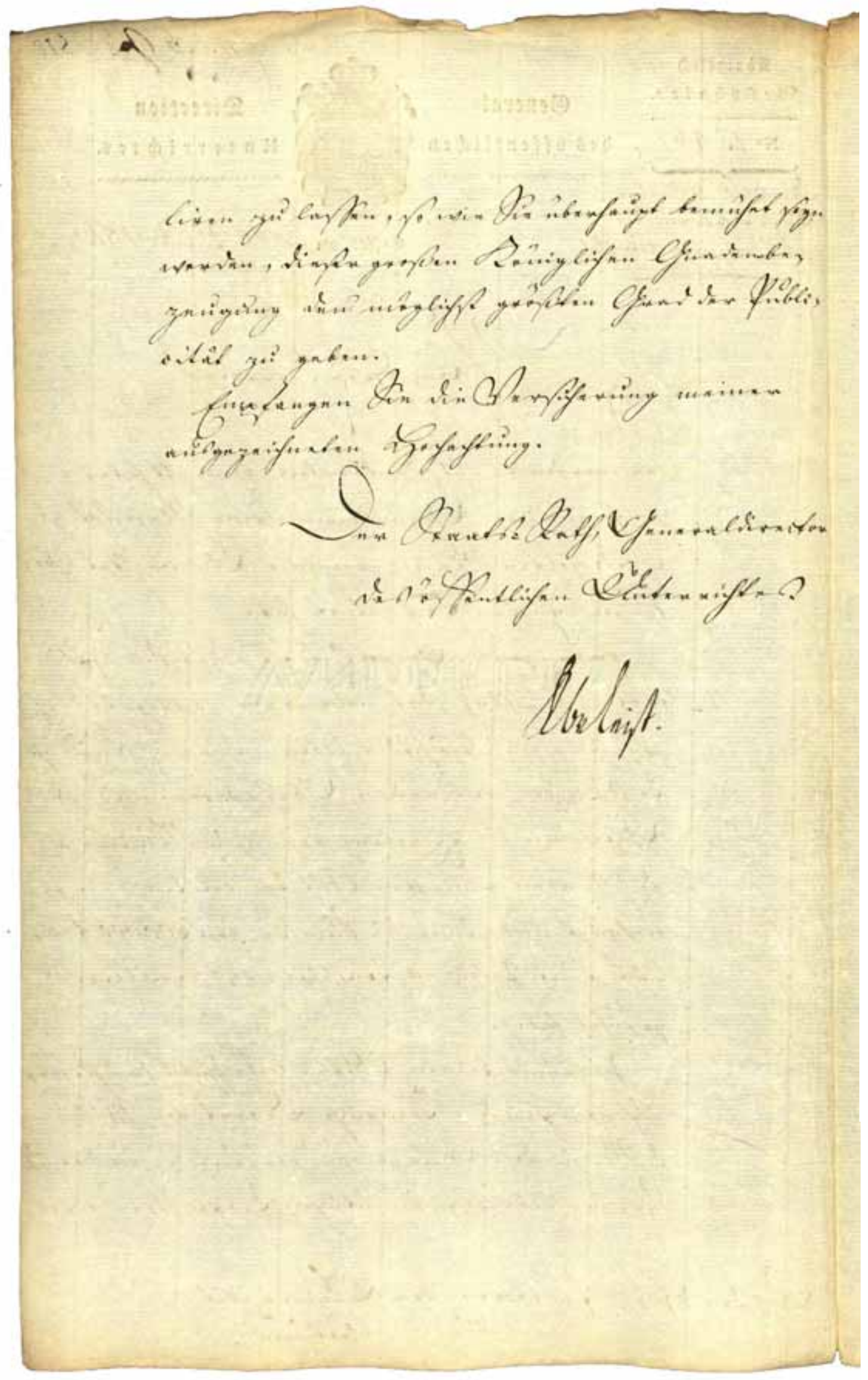

Abb. 5: Vorherige und diese Seite: Faksimile des Briefs des Generaldirektors des öffentlichen Unterrichts bei der Regierung des Königreichs Westfalen in Kassel, Staatsrat von Leist, vom 23. Juli 1810 an den Prorektor der Universität Göttingen, mit dem er der Universität das Edikt König Jérômes mit der Aufforderung zustellt, den Bau der Sternwarte fortzusetzen und dieser Bewilligung den größtmöglichen Grad der Publizität zu geben. 
Ende des 18. Jahrhunderts jedoch führten bahnbrechende Entdeckungen und Theorien innerhalb weniger Jahrzehnte zu einem Paradigmenwechsel. Eckpunkte dieser Entwicklung waren Herschels Uranus-Entdeckung 1781, die Entdeckung der ersten Planetoiden zwischen Mars und Jupiter ab 1801, die Kant-Laplacesche Theorie der Entstehung des Planetensystems (1755, 1796), die Gaußsche Bahnberechnung der Ceres 1801 und die nachfolgende Entwicklung der Störungstheorie, die schließlich zur Voraussage der Position des noch unbekannten Neptun durch Le Verrier und seine Entdeckung 1846 durch Johann Gottfried Galle (1812 - 1910) führte ${ }^{15}$.

Dies mag einen Eindruck von der Euphorie geben, mit der man um 1803 den kommenden Entwicklungen in der Astronomie entgegensah. Ergänzt werden muss dieses Bild durch die wichtigen Anwendungsgebiete der Astronomie im Vermessungswesen. Vor diesem Hintergrund ist die Schrift Borhecks zu bewerten, mit der er Maßstäbe für den Bau neuer Sternwarten setzte. Borhecks Untersuchungen gehen über seine Aufgaben als Baumeister der Sternwarte sicherlich weit hinaus.

Bei der Herstellung der feinen Risse hatte Borheck seine ohnehin schwachen Augen offenbar überanstrengt. Nach Erliegen der Bautätigkeit nahm er deshalb seinen Abschied und suchte ab Juni 1805 Erholung auf dem gepachteten Landgut im Hessischen (s. seine Nachschrift). Borheck sah sein Manuskript und die Pläne als sein persönliches Eigentum an und versuchte diese zu veröffentlichen. Göttinger Verleger wollten sich jedoch auf seine anspruchsvollen Forderungen hinsichtlich des Drucks nicht einlassen. Deshalb übergab er beide Bände dem einflussreichen Direktor der Göttinger Bibliothek, Justizrat Christian Gottlob Heyne

\footnotetext{
15 Vergleichbar mit diesem Aufbruch zu Beginn des 19. Jahrhunderts ist die intensive neuerliche Beschäftigung mit Planetensystemen seit etwa 1995 aufgrund der Entdeckung vieler größerer Körper im Edgeworth-Kuiper-Gürtel, dem äußersten Teil unseres Sonnensystems, und die Entdeckung von mehr als 100 Planeten um andere Sterne. Zu unserem Sonnensystem gehören der von Claude Tombaugh entdeckte „Planet" Pluto (1930) und die nur wenig kleineren Planetoiden Quaoar (2002) und Sedna (2004). Bei der Benennung der letzteren wurde mit der Tradition der Namensgebung auf Basis der griechischen Mythologie gebrochen und $\mathrm{Na}-$ men aus der Mythologie der amerikanischen Ureinwohner verwendet.
}

(1729-1812) $)^{16}$, der sich erboten hatte, über Christian Ludwig Stieglitz ${ }^{17}$ in Leipzig einen Verleger zu finden. Dies misslang jedoch und Heyne schrieb Borheck mit Datum vom 19. Juli 180518:

Unser Projekt, in Leipzig einen Verleger für Ibre Geschichte der Sternwarte zu finden, ist nicht gelungen: sehen Sie, hochgeschätzter Herr Oberbaucommissär, beygelegtes Schreiben des Herrn Dr. Stieglitz an, so werden Sie nicht weniger unzufrieden seyn als ich es bin. Ich muß also herumdenken u. abwarten wo sich einmal eine Gelegenheit zeiget zum Zwecke zu kommen. Was sagen Sie zu dem Vorschlag von Einrücken in das Berlinsche Journal an honorarium wird da aber nicht zu denken seyn. Nun müssen Sie ja wobl ein wenig eingerichtet seyn in Ihrem neuen Haußhalt. Die ietzigen warmen Tage geben bessere Hoffnung als die vorigen. Mit den besten Wünschen beharre ich ergebenst Heyne

Hierauf beließ Borheck seine Unterlagen weiter in Heynes Obhut, der sie wiederum an Stieglitz in Leipzig übergeben hatte.

Die Universität Göttingen betrieb währenddessen den Weiterbau der Sternwarte auch unter dem seit 1807 auf "chateau Royal de Napoléonshöhe" in Kassel residierenden König Jérôme Bonaparte und erreichte schließlich im Frühjahr 1810 die Bereitstellung von 200000 Francs verteilt auf fünf Jahre. Das vom 14. Juli 1810 datierte Edikt Jérômes ${ }^{19}$ sagt in Artikel 1: „Il sera construit un nouvel observatoire a Göttingen d'après le plan et le devis dressé par le Sr. Borbeck, architecte de l'Université, les quel plans et devis nous avons approwvé et approwvons." Zu diesem Zeitpunkt lagen Borhecks Manuskript und seine Pläne in Kassel vor und dienten der Regierung dazu, Entwurf und Kosten zu prüfen. Das Edikt, in dem ausdrücklich auf den von Borheck erstellten Plan und Bauanschlag verwiesen wird, stellte der Generaldirektors des öffentlichen Unterrichts, Staatsrat von Leist, mit Schreiben vom 23. Juli 1810 dem Prorektor der Universität Göttingen $\mathrm{zu}^{20}$ und fügte hinzu: „....und ersuche Sie dasselbe bey sämtlichen Professoren

\footnotetext{
16 Heyne war als Professor für klassische Philologie Mitglied der Philosophischen Fakultät und war als solcher auch mit der Sternwarte befasst, z.B. wirkte er als Prüfer für deren Inventarlisten und zeichnete diese gegen.

${ }_{17}$ Verfasser einer Enzyklopädie der Bürgerlichen Baukunst, s. auch Fußnote 1 im Beitrag von Christian Freigang.

${ }^{18}$ Borhecks Manuskript sind neben der Nachschrift die drei Briefe Heynes beigeheftet, die hier vollständig wiedergegeben sind.

${ }^{19}$ Universitätsarchiv Göttingen, Kuratoriumsakten.

20 Universitätsarchiv Göttingen, Kuratoriumsakten.
} 
circuliren zu lassen, so wie Sie überhaupt bemüht seyn werden, dieser großen Königlichen Gnadenbezengung den möglichst größten Grad der Publiæität zu geben. "Der Weiterbau der Sternwarte ging nun planmäßig voran und wurde auch durch den nochmaligen Regierungswechsel 1813 nur kurz unterbrochen. Im Herbst 1816 war die Sternwarte bezugsfertig. Obgleich Borheck anscheinend 1809 versuchte, wieder Einfluss auf das Baugeschehen zu erlangen $^{21}$, wurde die Leitung nun dem viel jüngeren Justus Heinrich Müller (1783-1825) übertragen, der 1810 zum Distrikts-Ingenieur für öffentliche Gebäude und 1814 zum Kloster- und Universitätsbaumeister ${ }^{22}$ ernannt wurde.

Die zu erwartende Entscheidung der Regierung in Kassel zum Weiterbau der Sternwarte muss schon länger im Raume gestanden haben, denn Borheck schrieb bereits am 30. November 1809 an Heyne, anscheinend mit der Bitte um Rückgabe seines Manuskripts. Heyne antwortete ihm mit Brief vom 8. Dezember 1809, dass er alle Bauakten (bereits 1807) an die Präfektur in Kassel habe abgeben müssen, darunter vermutlich auch Borhecks Manuskript und Pläne:

Woblgebohrener, Hochzuehrender Herr und Freund

Oft habe ich an Ihre Lage bey unsern traurigen Zeitumständen gedacht, und Sorge getragen - aber Ihr Brief vom 30. Nov. hat mich innig bekümmert und traurig gemacht; denn alles ist noch schlimmer als ich befürchtet hatte. Viele Hoffnung habe ich von dem erwünschten Erfolg Ihrer neuen Rückkehr zu den Bangeschäften nicht, da ich die überbäufte Concurrenz und den Vorzug der Ausländer mehr als zu gut weiß aus den hiesigen Ereignissen. Fraglich ist, ein Versuch zu machen. Leider habe ich von allen Ibren Rissen nichts in Händen, ich habe alles an den Präfect abgeben müssen um es nach Cassel einzusenden, bereits im Anfang der neuen Ordnung der Dinge. Papiere von Ihnen werden noch bey dem Observatorium seyn, aber die sind auch nicht in meiner Gewalt; ich kann sie auch nicht zurückerbalten noch Ihnen etwas senden, wenn ich nicht den Schein von Ibnen erhalte, daß Sie das Empfangene in der bestimmten Zeit wieder zurücksenden wollen. Melden Sie mir nur den Riß, welchen Sie verlangen, beschreiben Sie mir ihn, so will ich sehen, ob er vielleicht bey dem Observatorium ist, will Hrn. Oppermann ${ }^{23}$ zu Hülfe nehmen, und bemühet seyn zur Sendung Rath zu treffen. Ich bin ganz. aus den vorigen Verbältnissen

\footnotetext{
${ }^{21}$ Erwähnt im Brief Heynes an Borheck vom 8. 12.1809. ${ }^{22}$ Friedrich Saalfeld, Gelehrtengeschichte der Universität Göttingen von 1788 bis 1820, Hannover 1820, S. 382

${ }^{23}$ Baukommissar Heinrich Julius Oppermann (1752-1811), Nachfolger von Borheck und Vorgänger von Müller.
}

heraus; die Bausachen zumabl gehen ganz durch den Präfect; der arme Oppermann hat eine klägliche Rolle. Wo aber ist eine Lage, die nicht kummervoll wäre! Könnten Sie nur einigermaaßen Brod durch die Landwirthschaft erwarten: so wären Sie glücklicher. Danken Sie dem Himmel daß Sie nicht hier geblieben sind: Ibre Lage wäre noch schlimmer geworden. Hier ist der gemeine Trost: es könnte alles noch schlimmer seyn. Uberlegen Sie alles, und geben Sie mir gewünschten Nachrichten.

\section{Aufrichtig beharre ich \\ Euer Woblgebohren Ergebenster Freund u. Diener Heyne}

Am 29. Januar 1810 schrieb der 80-jährige Heyne schließlich noch einmal an Borheck:

Ich bedaure es herzlich, daß ich nach allem Herumsuchen u. Herumdenken u. Herumfragen von den von Ew. Woblgbn. bemerkten 2 Heften doch auch nicht die geringste Spur entdecken kann. Auf der Bibliothek haben sie nicht gebört; ich für mich wüßte nichts anzufangen (anzufragen?) gewußt haben; Wahrscheinlich müssen Sie aus Leipzig vom Hrn. Dr. Stieglitz, der das Werk unterbringen sollte, nicht wieder zurück gekommen seyn: wo von ich wie Sie keine Erinnerung habe, ob, wie u. an wen die Zurückschickung geschehen seyn mag. Ich habe seinen Brief aufgesucht, kan aber nichts daraus nehmen; will ibn indessen doch zur Einsicht bey legen. Vielleicht haben Sie ein besser Gedächtniß.

Wind von neuem Bauen ist hier genug gemacht; zuverlässig ist noch nichts, am wenigsten der Fonds woher. Ich wünsche Ihnen Muth und Fassung Ihr Schicksal zu ertragen und voraus Gesundheit, für welche alles doppelt dünkt. Dies empfinde ich bey dem veränderlichen Witterung.

\section{Leben Sie wobl. Ergebenst $H$.}

Borheck machte sich nun selbst auf die Suche nach seinen Unterlagen und erfuhr im Frühjahr 1812, dass seine Schrift zwei Jahre früher in Kassel vorgelegen hatte. Wie in seiner Nachschrift dargelegt, schrieb er nach Kassel, erhielt keine Antwort und wurde dort schließlich im Juni 1812 persönlich vorstellig. Auf seine Vorhaltungen erhielt er die Antwort, man habe sein Manuskript, das auch von Prof. Gauß befürwortet worden sei, für eine offizielle Bauakte gehalten, wolle aber nunmehr Herrn Müller beauftragen, ihm die Akten auszuhändigen. Wiederum wartete Borheck vergebens. Als er jedoch am 8. Oktober 1812 Müller persönlich in dessen Büro in Göttingen aufsuchte, konnte er sein Manuskript dort widerstandslos entgegennehmen. Müller hatte 

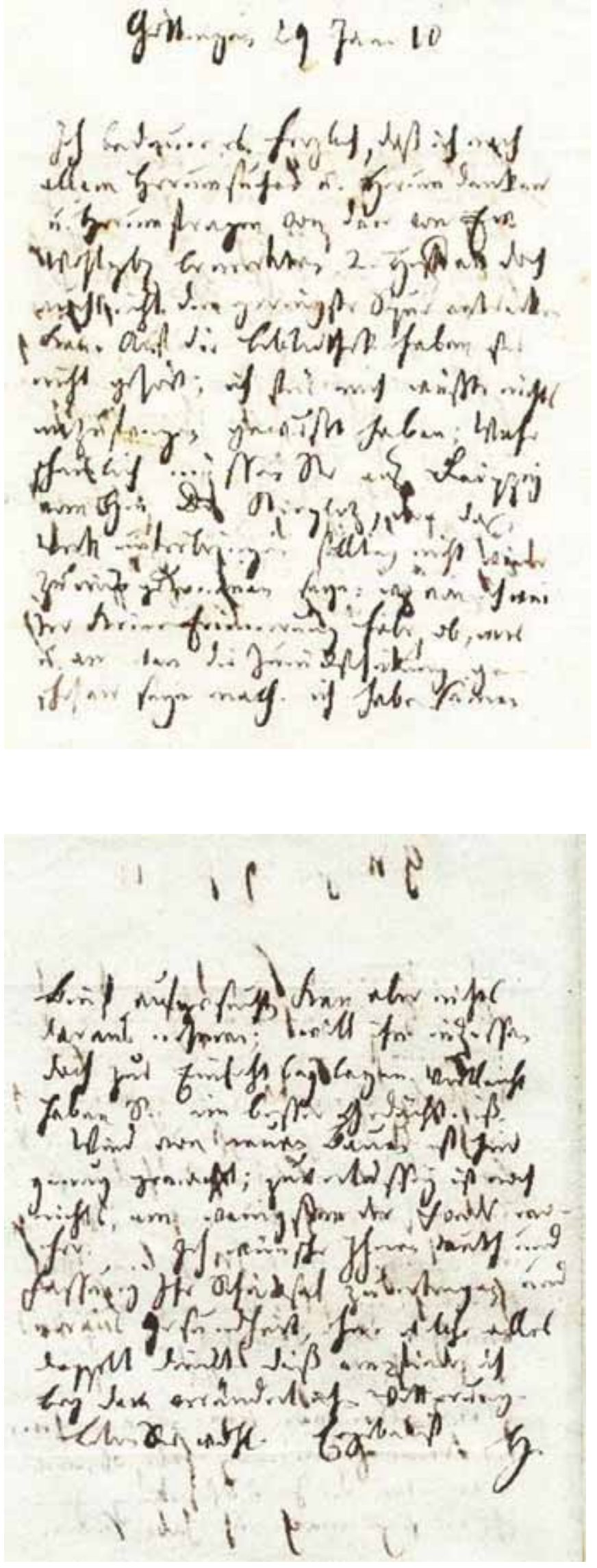

Abb. 6: Vorder- und Rückseite des letzten von drei dem Manuskript nachträglich beigehefteten Briefen Christian Gottlob Heynes, datiert vom 29. Januar 1810, in dem er Borheck mitteilt, dass dessen Manuskript unauffindbar sei. 
sich die notwendigen Details kopiert und das Manuskript war für den Bau nicht mehr erforderlich. Die Odyssee hatte ein Ende.

An eine Publikation des Manuskripts war 1812 wegen des direkten Bezugs auf Göttingen ohne grundlegende Umarbeitung nicht mehr zu denken. Da Gauß den so höchst kompetent entworfenen Bau trotz gewisser Mängel sehr schätzte, kann man vermuten, dass Borheck ihm das Manuskript persönlich übereignet hat. Borheck nahm seine Dozententätigkeit über verschiedene Zweige der Baukunst 1820 wieder auf ${ }^{24}$ und starb erst 1834.

Wenn man Borhecks Unterlagen mit modernen Plänen für Universitätsbauten vergleicht, fällt auf, wie viele Details seinerzeit ungeplant bleiben durften und der Entscheidung des Baumeisters vor Ort unterlagen. Nicht hinreichend ausgearbeitet wurde von Borheck z.B. die Konstruktion des Deckengewölbes, das die Kuppel und das dort unterzubringende Teleskop trägt, sowie der Mechanismus der geplanten Drehkuppel, während andere Details, wie der aufwändige Mechanismus zum Öffnen und Schließen der Meridianspalte, akribisch beschrieben werden. Die Drehkuppel findet im Text nur an einer Stelle Erwähnung und die technischen Zeichnungen zu diesem Thema (Abb. 26 und 27) ebenso wie eine Zeichnung zur Gewölbekonstruktion sind nicht unter die sechs nummerierten Tafeln eingereiht, die zur Veröffentlichung bestimmt waren. $\mathrm{Zu}$ dieser Zeit waren Drehkuppeln noch nicht üblich und die älteste funktionierende solche Kuppel scheint die auf dem (verhältnismäßig kleinen) Dunsink Observatory in Dublin gewesen zu sein (1785). In wieweit Müller beim Weiterbau der Göttinger Sternwarte versucht hat, den von Borheck vorgeschlagenen Mechanismus eines Holzräderwerks zu realisieren, muss noch geklärt werden. Faktisch jedoch hat die Sternwarte bis 1888 keine - oder zumindest keine funktionierende - Drehkuppel gehabt. Borhecks Planung muss aus der Zeit heraus beurteilt werden und kann heutigen Maßstäben für eine Bauauftragserteilung nicht gerecht werden. In jener Zeit spielten Improvisation und das Vertrauen in die Fähigkeit des Baumeisters, für aufkommende Probleme eine adäquate Lösung zu finden, eine wichtigere Rolle als heute. Anderseits waren Änderungen am geplanten Bau vermutlich einfacher zu erreichen als es heute möglich ist. Auch im Abstand von 200 Jahren bleiben Borhecks Pläne für die Göttinger Sternwarte ein großer Wurf und sein Schmerz darüber, dass zunächst kriegerische Ereignisse zum Baustopp führten und dann die neue Westfälische Regierung in Kassel ihm die Bauleitung nicht wieder übertrug, bleibt verständlich. ${ }^{24}$ Friedrich Saalfeld, Gelehrtengeschichte der Universität
Göttingen von 1788 bis 1820, Hannover 1820, S. 382 . 


\section{Architekturhistorische Bemerkungen zur Göttinger Sternwarte}

\author{
von Christian Freigang, Frankfurt a.M.
}

Architekturgeschichtlich betrachtet stellt die Göttinger Sternwarte in mehrfacher Hinsicht ein höchst bemerkenswertes Gebäude dar. Zum einen handelt es sich um eine geradezu idealtypische - und hervorragend erhaltene - Verwirklichung der neuen Baugattung „Sternwarte“ in der Zeit um 1800. Zum anderen manifestiert sich mit der Errichtung des Baues ein grundsätzlicher gestalterischer Umschwung in der Göttinger Baugeschichte. Die repräsentative Architektur der Stadt war am Ende des 18. und noch zu Anfang des 19. Jahrhunderts vor allem von einem französisch-klassizistisch geprägten Spätbarock gekennzeichnet. Mit dem Bau der Sternwarte vollzieht sich indessen der Umschwung zu einem „internationalen“ klassizistischen Idiom, welches unübersehbar griechisch-antike Formen aufnimmt. Verantwortlich hierfür war eindeutig der Einfluss der französischen Verwaltung des Königreichs Westfalen unter König Jérôme, dem Göttingen in der Zeit um 1810 unterstand.

Schon kurz nach Gründung der Universität in den Jahren 1834/37 setzte der Sternwartenbau gewisse Akzente im Baugeschehen der Stadt. Obwohl die Astronomie in Göttingen im 18. Jahrhundert bis auf Tobias Mayer (1751 bis 1762) keine bedeutenden Vertreter aufzuweisen hatte, galt sie als Fach von großem Prestige und wurde reichlich mit guten Instrumenten ausgestattet. Im Sinne dieser Förderung war schon 1748 durch König Georg August der Bau einer Universitätssternwarte genehmigt worden. Den Auftrag hierzu erhielt der Naturwissenschaftler Johann Andreas von Segner. Nachdem sich mehrere Standorte vor allem auf Kirchtürmen als zu wenig erschütterungsfrei erwiesen hatten, wurde schlieBlich das erste Observatorium auf einem der Mauertürme auf der Südseite der Stadt untergebracht. Es handelte sich um einen zweizonigen, von einem Kegeldach bekrönten Aufsatz auf rundem Grundriss. In der unteren Zone lief ein Rundgang um, im ausladenden Geschoß darüber befand sich das Observatorium. Trotz mehrerer Erweiterungsbauten in Form von Erkern erwies sich dieses erste Göttinger Observatorium jedoch schnell als zu klein sowie als technisch ungenügend und wurde schließlich 1821/22 vollständig abgetragen. Schon seit Ende des 18. Jahrhunderts sann man hierfür in Hannover auf Abhilfe. Mit der Ausführung wurde der Universitätsbaumeister Georg Heinrich Borheck (1751-1834) beauftragt. Der Architekt hatte sich vor allem durch Umbaupläne der Universität und die Errichtung des Accouchierhauses, der ersten eigenständigen Frauenklinik in Deutschland, einen lokalen Ruhm erworben. Die technisch und baukünstlerisch nicht einfache Aufgabe des Sternwartenbaus löste er mit Hilfe vor allem des Gothaer Hofastronomen Franz Xaver von Zach und des Justizrates Johann Hieronymus Schröter sowie der Angaben des Architekturtraktates von Christian Ludwig Stieglitz ${ }^{1}$. Zach hatte die herzogliche Sternwarte auf dem Seeberg bei Gotha, Schröter das Observatorium von Lilienthal erbaut. 1801 hatte Borheck zunächst eine Baustelle unmittelbar außerhalb des Südostabschnitts des Walles vorgeschlagen ${ }^{2}$. Auf Anraten des 1802 in Hannover weilenden Architekten Friedrich Weinbrenner war indessen der heutige Standort vor dem Wall bestimmt worden. Hierfür sah Borheck zunächst einen Einflügelbau vor, der eine zentrale Tambourkuppel, ein flaches Walmdach und einen monumentalen Giebelportikus auf der Südseite erhalten sollte. Damit hätte der Bau einem kleinen Landschlösschen geähnelt. Doch im Juli 1802 kam offenbar der Kontakt zu den vorgenannten Astronomen zustande. Schroeter riet, sich ganz an die vorbildliche, dreiflügelige Anlage auf dem Seeberg bei Gotha zu halten. Auf der Grundlage dieser Konsultationen erstellte Borheck nun ein umfangreiches Konzept zum Bau der Göttinger Sternwarte, welches sich sogar in einem handschriftlichen Traktat niederschlug,

\footnotetext{
${ }^{1}$ Stieglitz, Christian Ludwig: Encyklopädie der bürgerlichen Baukunst, Bd. III. Leipzig 1797, Art. „Observatorium“, v. a. 23-26 u. Tafelbd, 4. Tl., Taf. I, Fig. 1-2.

2 UAG, Kur. 13 a/8, vol. III
} 
das sich noch heute im Besitz der Sternwarte befindet. Dieses Traktat verdient in architekturgeschichtlicher Hinsicht besondere Beachtung. Denn wie Borheck in seinem Text zu Recht hervorhebt, handelte es sich um die erste umfassende Erläuterung zu dieser technisch anspruchsvollen Bauaufgabe, bei der die Besonderheiten der Lage und der besonderen statischen Stabilität eine gewichtige Rolle spielen. Doch ist die Schrift mehr als ein Ingenieurstraktat, äußert sich Borheck doch in bester architekturtheoretischer Tradition zum Zusammenhang zwischen der konstruktiven „Festigkeit“ eines solchen Gebäudes, seiner Funktion (,Bequemlichkeit“) und der „Schönheit" seines Äußeren. In puncto Bequemlichkeit fordert er etwa eine Differenzierung verschiedener Gebäudetrakte, von denen das Hauptgebäude mit einer großzügigen Inneneinteilung und guter Beleuchtung sowie den notwendigen Öffnungen für die Instrumente zu versehen sei. An diesen Hauptflügel sollen unmittelbar die beiden Wohntrakte des Sternwartenleiters und seines Gehilfen anschließen, damit diese jederzeit ihre Beobachtungen auch unvorherzusehender Ereignisse am Sternenhimmel durchführen könnten. Eine Reihe von Maßnahmen zur Isolierung gegen Erschütterung und Temperaturschwankungen ergänzt die Vorschläge. Die technische Stabilität werde insbesondere durch eine sorgfältig nivellierte Terrassierung von knapp zwei Metern Höhe erreicht. Die solchermaßen erhöhte Lage gibt Borheck denn auch Anlass zu Äußerungen bezüglich der Schönheit des Gebäudes. Da es sich um ein in besonderem Maße exponiertes öffentliches Gebäude handele, müsse es in seinem Äußeren so sorgfältig gestaltet sein, dass es einen „Charakter“ ausdrücke. Im Fall der neuen Baugattung „Sternwarte“ sei dieser am ehesten „ein edler fester [...], der auf die Einbildungskraft wirkt, und Stoff zum Nachdenken gibt“. Eine wohlgefällige Proportionierung aller Teile („Symmetrie und Eurythmie“) mache „immer einen edlen Eindruck; und dieser kann durch zweckmäßige Anwendung einer Säulenordnung, noch erhöhet werden". Wenn auch die Ausführungen Borhecks nicht als besonders originell gelten können, so zeigen sie doch, wie er das Bauwerk auf der Grundlage klassischer architekturtheoretischer Erörterungen - die sich insbesondere auf die französische Architekturdebatte der Mitte des 18. Jahrhunderts zurückführen lassen - plant.
Das umfangreiche Traktat war bis 1805 druckreif, doch scheiterten Borhecks Bemühungen um eine Veröffentlichung als eine allgemeine und aufwendig präsentierte Anleitung zum Sternwartenbau. Mit der Errichtung des Königreichs Westfalen kamen das Manuskript und die begleitenden Aquarelle zur Bauverwaltung der Départementshauptstadt Kassel. Dort wurden sie offenbar als amtliche Pläne, nicht als Erfindung Borhecks erachtet, und dienten als Grundlage bezeichnender Veränderungen.

Ganz entsprechend den theoretischen Ausführungen Borhecks besteht sein architektonischer Entwurf aus einer Dreiflügelanlage. Im Hauptflügel ist das eingeschossige, mit einem Terrassendach gedeckte und von einer zentralen Tambourkuppel mit dem Fernrohr gekrönte Observatorium untergebracht. Die zweigeschossigen, mit flachen Walmdächern gedeckten Seitenflügel enthalten die Wohnungen der Astronomen. Um eine perfekte Stabilität zu gewährleisten, liegt der Bau erhöht auf einer Terrassenplattform, von der aus auch Observationen durchgeführt werden sollen. All diese Dispositionen entsprechen der Gothaer Sternwarte; für Borheck handelte es sich aber ganz und gar nicht um eine sterile Kopie eines Vorbildbaus, sondern um ein in allen funktionalen und ästhetischen Aspekten umsichtig konzipiertes Projekt - eine Art idealer Sternwarte der Zeit um 1800. Und nach diesem Plan wurde der Bau der heute noch stehenden Göttinger Sternwarte im April 1803 auch begonnen.

Im Vergleich zu dem Erstentwurf von 1802 (Abb. 22) enthielt das nunmehr begonnene Hauptgebäude einige Veränderungen. An die Stelle des übergiebelten Säulenportikus ist eine pilastergerahmte Eingangsloggia getreten, in die zwei dorische Säulen eingestellt sind; der Dreiecksgiebel ist entfallen. Die Eckrisalite des Hauptbaus sind durch Doppelpilaster auffällig markiert. Kein anderes unter den damaligen Göttinger Gebäuden war architektonisch aufwendiger instrumentiert. 1804, als die Terrassierung und die Fundamentierung gerade vollendet waren, stockten die Bauarbeiten und mussten infolge der französischen Invasion im Folgejahr ganz eingestellt werden. Borheck zog sich auf ein hessisches Landgut zurück; seine Pläne gelangten an die dortige Bauverwaltung. 1810 schließlich wurde der Bau auf Anweisung König Jérômes wieder 

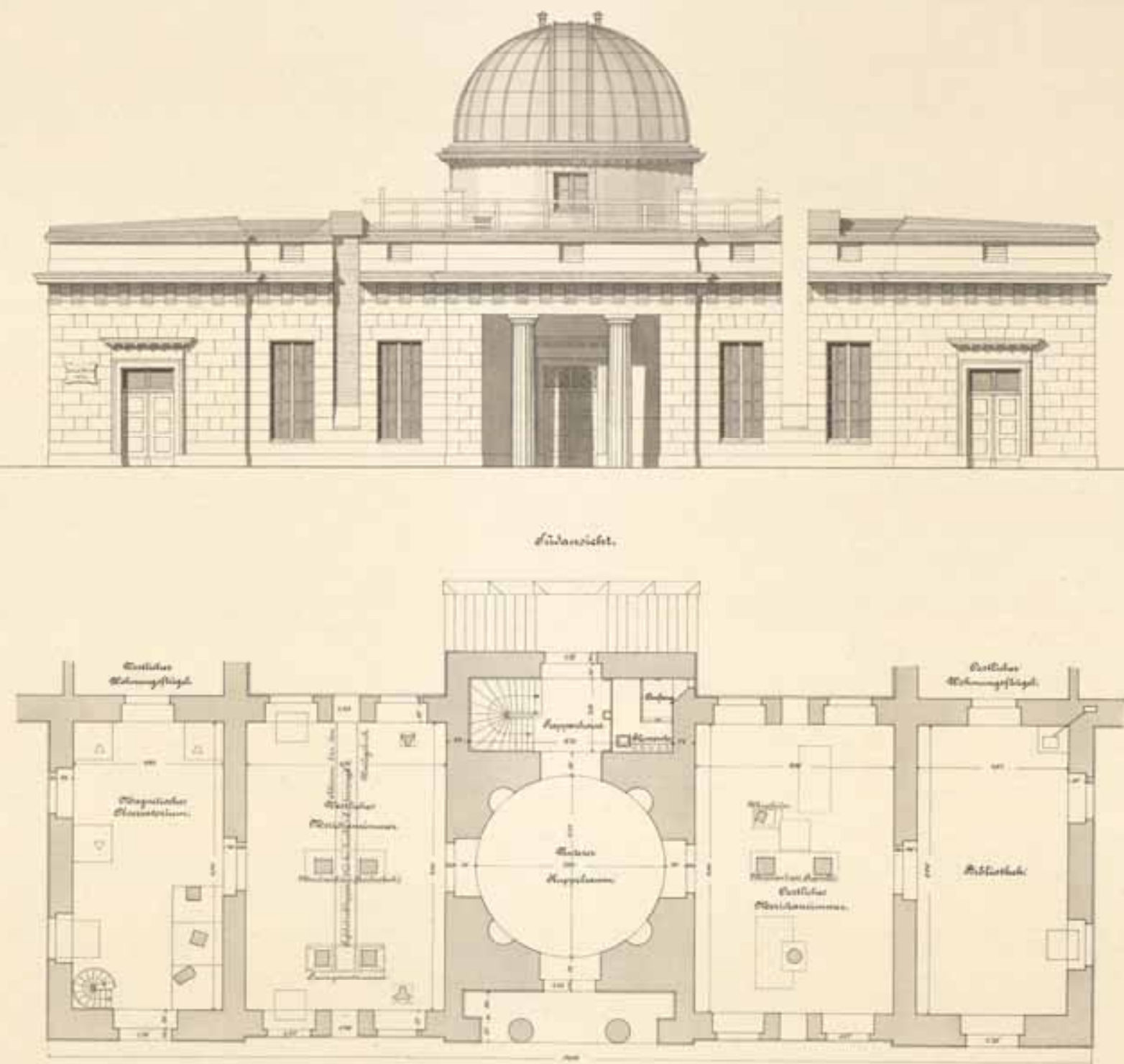

Abb. 7: Ansicht von Süden und Grundriss der Sternwarte für den Umbau 1887/88. Bis auf die Form der Kuppel, die breiteren Meridianspalte und die kleinen Fenster im Gesims gibt dies die Ansicht des Müllerschen Baus wieder. Die Fundamente in den Meridianzimmern sind auf die zu dieser Zeit noch genutzten Meridiankreise von Reichenbach und Repsold sowie ein Passageinstrument zugeschnitten. An der Stelle des Reichenbachschen Meridiankreises im westlichen Meridianzimmer ist heute noch der Nullpunkt der Gaußschen Landesvermessung zu besichtigen. Im westlichen Vorbereitungsraum, dem damaligen magnetischen Observatorium und der heutigen Bibliothek, ist die noch vorhandene Wendeltreppe eingezeichnet (s. Abb. 13). Im östlichen Vorbereitungsraum war um 1888 die Bibliothek untergebracht. Er wurde 1926 zum Hörsaal umgebaut. 
aufgenommen, die Baupläne indessen nach einer Begutachtung des Generalbauinspektors Jussow ${ }^{3}$ vom Departementsoberbaurat August Leopold Crelle in der äußeren Erscheinung und in der Konstruktion durchgreifend überarbeitet ${ }^{4}$. Durch Justus Heinrich Müller, seit 1814 neuer Universitätsbaumeister, wurde der Bau ausgeführt und bis 1816 vollendet. Crelle bzw. Müller behielten die Disposition Borhecks bei, weil die Fundamente bis auf ihre Oberkante bereits errichtet waren, und änderten nichts an der vorgesehenen Raumeinteilung, um so mehr aber am äußeren Erscheinungsbild der Sternwarte. Schon Borheck hatte das Vestibül kreisrund geplant, weil dadurch ein fester Unterbau für die Beobachtungskuppel zu gewährleisten war. Nunmehr erhielt das weiterhin kreisrunde Vestibül vier, in den Diagonalachsen eingelassene Wandnischen, die wohl zur Aufnahme von Standbildern vorgesehen waren. Wie schon im Projekt Borhecks vorgesehen, erreichte man über große Flügeltüren seitlich die beiden Meridiansäle, von denen jeweils eine weitere große Flügeltür Zugang zu den Räumen in den Eckrisaliten gibt. Im Westen befand sich hier das Labor von Gauss, im Osten vermutlich die Bibliothek. Vestibül, Meridiansäle und Eckräume durchmaßen somit in voller Höhe den $\mathrm{Bau}$; es bestand also - wie dieser an seinem Äußeren auch anzeigt - keine weitere Geschoßeinteilung. In seinem Äußeren wurde der Hauptbau in präzise gearbeitetem Sichtquaderwerk ausgeführt; die Pilaster fielen fort. Die Säulen der Eingangsloggia wurden nunmehr durch griechische dorische Säulen ohne Basis ersetzt, und auch das Gebälk mit seiner Abfolge von Metopen und Triglyphen archäologisch genau dieser Ordnung angepasst. Die Mauerteile (wohl an den Seitenflügeln), die Borheck gemäß seinem Traktat unverputzt lassen wollte, waren nunmehr mit einem Putz mit Fugenmalerei versehen worden. Somit stellt die Sternwarte den ersten Göttinger Bau dar, für den die griechisch-antiken Formen eines archäologisch getreu recherchierenden Klassizismus verbindlich wurden. Für den alternden Borheck, der den Bau 1812 besuchte, war diese Wiederaufnahme griechisch-antiker Formen ein Regelverstoß gegen die ihm vertrautere römische dorische Ordnung, welcher ,aus bloßem Kunstneid“" vorgenommen worden sei.

${ }^{3}$ Thiersch, Hermann: Göttingen und die Antike, Göttingen 1926, 57, Anm. 115.

${ }^{4} \mathrm{UAG}$, Kur. 13 a 8.
Der hohe gestalterische Anspruch der Sternwarte blieb auch in ihrer ausgeführten Version erhalten, wurde aber mit neuen Akzenten bereichert: Die Portalloggia mit eingestellten Säulen und das nachfolgende kreisrunde Vestibül gehören zu Standardmotiven des gehobenen Wohnbaues um 1800. Auch die jüngst in mehreren Schichten freigelegte Innenbemalung des Vestibüls zeigt, dass durch einen repräsentativen Charakter die Würde und Bedeutung der Göttinger Astronomie anschaulich zum Ausdruck gebracht werden sollte. An Kuppelfuß und -scheitel lief in der ersten Ausmalung eine antikisierende LotusPalmetten-Ranke um; die Wände des Vestibüls waren in gemalte Felder eingeteilt. Hinzu kommt die gärtnerische Gestaltung des unmittelbaren Umfeldes der Sternwarte: nach Süden erstreckt sich die Terrainaufschüttung als breite Terrasse, von der eine Treppe in den im Sinne eines Landschaftsparks gestalteten Garten hinaufführt. Auf der Nord- und Südseite durfte jedoch der Blick aus den Meridianspalten nicht behindert werden.

Die architektonischen Ambitionen der Sternwarte führten somit insgesamt dazu, die Göttinger Architektur auf einen zeitgenössischen aktuellen Stand zu bringen, dem das spätbarockklassizistische Idiom Borhecks offenbar nicht mehr gerecht wurde ${ }^{5}$. Auch die Ausbildungswege der beteiligten Architekten machen diesen Umschwung überdeutlich. Borheck hatte in Göttingen Mathematik studiert und sich offenbar weitgehend autodidaktisch sein architektonisches Wissen angeeignet. Crelle hingegen hatte 1802 in Berlin das Große Architekturexamen abgelegt und war anschließend Oberbaurat in Westfalen geworden ${ }^{6}$. Justus Heinrich Müller hatte in Kassel unter Jussow studiert und gearbeitet ${ }^{7}$. Beide schlossen mit ihrem an griechische Formen angelehnten Vokabular an aktuelle Strömungen in Kassel, Braunschweig und Berlin an. Müller sollte die neue Formensprache noch für weitere wichtige Bauten in der Universitätsstadt anwenden, etwa für die - im II. Weltkrieg zerstörte - Neue Anatomie in der Nähe des Bahnhofs sowie für einen ephemeren Triumphbogen am westlichen Ende des Universitätsreitgeländes. Auslöser dieser Neuorientierung in der Göttinger Architektur war die Tatsache, dass im Königreich Jérômes

\footnotetext{
${ }^{5}$ Vgl. hierzu auch Johann Dominikus Fiorillos kritische Rezension von Borhecks Traktat zum Bau von Landkirchen, in: GGA 1808, II, 1329-1332.

6 Zu Crelle: Allgemeines Künstler Lexikon, Bd. 22, 222

7 Zu Müller: UAG, Kur. 13 d 5, Nr. 2-3, 8-9, 11-15.
} 
Kassel die Residenzstadt war und entsprechend Jussow als Generalbauinspektor zuständig für die Göttinger Bauaktivitäten war. Crelle überging Borhecks Plan ebenfalls in seiner offiziellen Funktion im Reich von Napoleons Bruder. Jussow oder Krahe waren in ähnlicher Funktion schon 1808 für die Errichtung eines ephemeren Triumphtors für den Einzug König Jérômes in Göttingen tätig gewesen ${ }^{8}$. Die neue zentrale Verwaltung wirkte sich also auch auf das architektonische Gepräge Göttingens aus, das nunmehr sich von der regionalen spätbarocken Tradition abwandte.

Um die Bedeutung der Sternwarte in ihrem vollen Ausmaß zu verstehen, sind indessen noch einige zusätzliche Aspekte anzusprechen: Zur selben Zeit, in der der Göttinger Bau in Planung war, bemühte sich der Braunschweigische Herzog Carl Wilhelm Ferdinand um eine eigene Universität. Er versuchte dazu, den zu dieser Zeit in Braunschweig und Helmstedt lebenden, bereits berühmten Mathematiker Carl Friedrich Gauß zu berufen sowie eine große Sternwarte zu erbauen. Als technischer Berater wirkte eben derselbe
Franz Xaver von Zach, der auch Borheck zur Seite stand. Als Architekt arbeitete kein geringerer als Peter Joseph Krahe, der 1803 herzoglicher Baudepartementsleiter geworden war, das Projekt einer großen zweigeschossige Rotunde aus ${ }^{9}$. Das Tauziehen um Gauß gewann schließlich Göttingen, selbst wenn die technische Qualität der Sternwarte dem Mathematiker später ungenügend erschien. Der aufwendige Entwurf Borhecks erklärt sich wohl jedenfalls auch aus dieser Konkurrenzsituation, in die er überdies direkt involviert war. Borheck hatte sich nämlich 1803 eben mit seinen Sternwartenplänen auf die Braunschweiger Stelle beworben, welche schlieBlich Krahe erhalten sollte. Auch das ausführliche Traktat Borhecks wollte sich ja als allgemein gültiger Beitrag für die Konstruktion von Sternwarten verstehen und den Verfasser als Spezialisten gerade in dieser Bauaufgabe ausweisen. Um so bitterer mag es für ihn gewesen sein, dass er weder die Stelle in Braunschweig erhielt noch die Fertigstellung der Göttinger Sternwarte nach seinen eigenen Plänen erleben konnte ${ }^{10}$.
8 Dorn, Reinhard: Peter Joseph Krahe. Leben und Werk, Bd. III, Braunschweig 1997, 19-20, Kat. 538.

\footnotetext{
${ }^{9}$ Ibid., Bd. II, Braunschweig 1971, 93-95.

10 zusätzliche Literatur:

Imhof, Andres: Georg Heinrich Borheck (1751-1834), Leben, Arbeiten und Wirken eines Göttinger Oberbaucommissarius; Magisterarbeit Universität Göttingen, 1997. Oszmer, Sabine: Die Göttinger Universitätssternwarte. Magisterarbeit Universität Göttingen, 1991.

„Architektur und Städtebau von der Mitte des 17. Jahrhunderts bis 1866“, in: Ernst Böhme/Rudolf Vierhaus (Hrsg.): Göttingen, Geschichte einer Universitätsstadt, Bd. 2. Vom Dreißigjährigen Krieg bis zum Anschluss an Preußen - Der Wiederaufstieg als Universitätsstadt (1648-1866), Göttingen 2002, S. 765-812.
} 


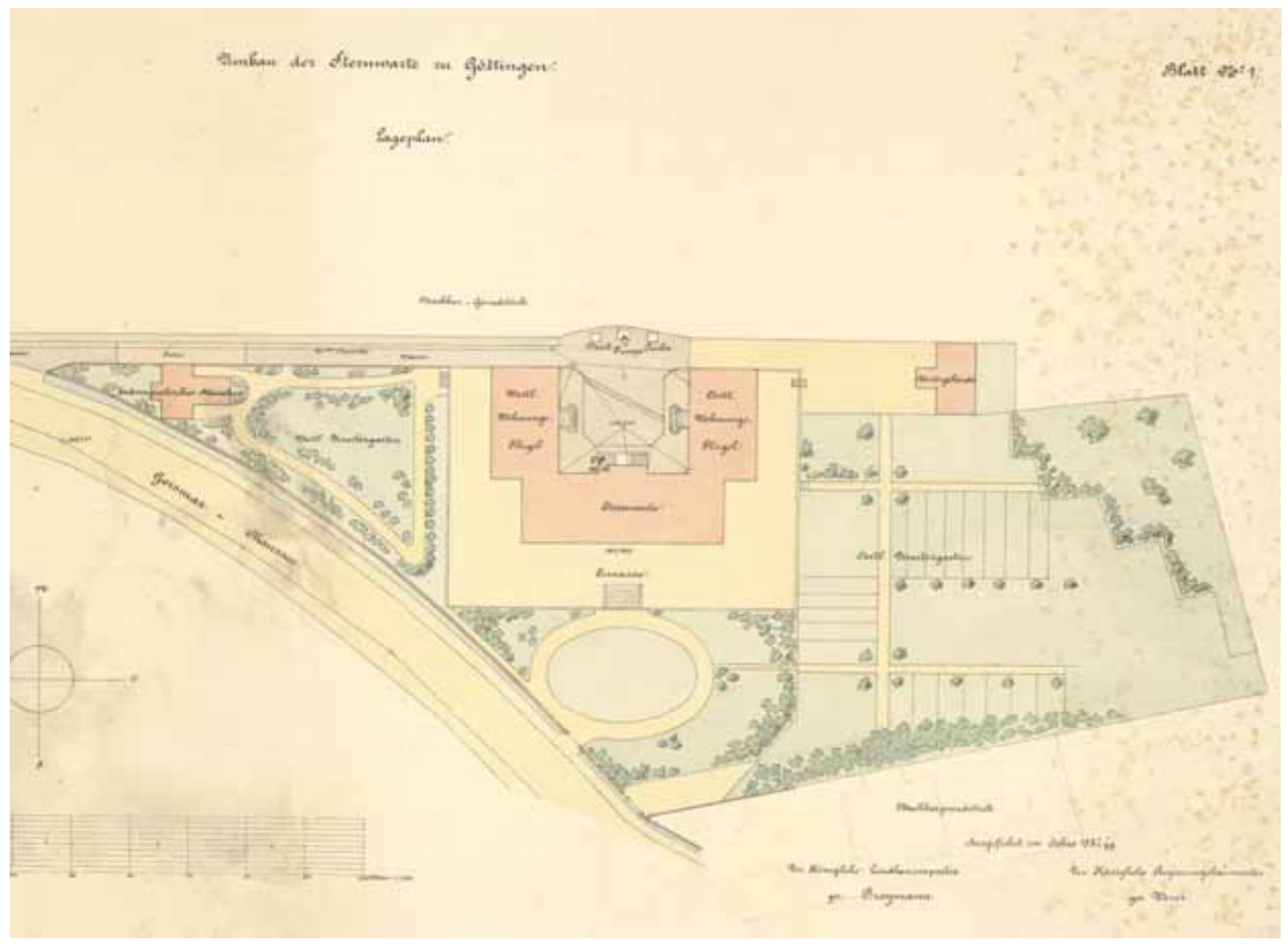

Abb. 8: Lageplan der Sternwarte aus der Zeit des Umbaus 1887/88. Links das magnetische Häuschen. 


\section{Naturwissenschaftsarchitektur in der Historiographie der Naturwissenschaften}

\author{
Nicolaas Rupke, Göttingen
}

Die Veröffentlichung von Georg-Heinrich Borhecks (1751-1834) Manuskript über seine Pläne für den Bau der Göttinger Sternwarte kommt zu einem günstigen Zeitpunkt - günstig nicht nur, weil die Universität Göttingen im Jahr 2005 des 150. Todestages des ersten Direktors der Sternwarte, Carl Friedrich Gauß (1777-1855), gedenkt, sondern günstig ganz allgemein in Hinblick auf aktuelle Strömungen in der Historiographie der Naturwissenschaften: Zunehmend wird die wichtige Rolle der architektonischen Stätten und generell der ,situatedness“ in der Entwicklung der Naturwissenschaften erkannt. Naturwissenschaftliche Rationalität - so wird erklärt - sei ausnahmslos „positioned rationality“, sie sei „situated“. Die traditionelle abstrahierende Perspektive eines neutralen und universalen „view from nowhere" sei in Wahrheit selbst eine privilegierte, parteiische Sichtweise, ein „God trick“" Dieser Ansatz in der Historiographie der Naturwissenschaften, bekannt als ,geography of scientific knowledge“, bezieht eine Vielzahl unterschiedlicher „Räume des Wissens“ ein, von den einzelnen konkreten Orten naturwissenschaftlichen Forschens bis zur räumlichen Mobilität von naturwissenschaftlichen Erkenntnissen, besonders die Prozesse des Wissenstransfers. Die konkreten Orte reichen dabei von ganzen Kontinente über Länder, Regionen und Städte bis zu einzelnen Universitäten und ihren Gebäuden Sternwarten, Museen, Laboratorien usw..

1 Vgl. Haraway, Donna: „Situated Knowledges: The Science Question in Feminism and the Privilege of Partial Perspective", in: Feminist Studies 14(3) (1988), 575-599.
Gegenwärtig gilt das Interesse besonders so nicht-elitären Stätten wie Kaffeehäusern und Gaststätten, aber auch Abendgesellschaften der sozialen Oberschicht. Einen Überblick über die reiche Ernte von Studien zur, geography of scientific knowledge“ aus den letzten beiden Jahrzehnten hat vor kurzem David Livingstone in einem sehr lesenswerten Buch gegeben. ${ }^{2}$ Der vorliegende Essay soll auf diese historiographischen Trends aufmerksam machen und dabei eine besondere Kategorie naturwissenschaftlicher Stätten in den Mittelpunkt stellen, nämlich die Gebäude.

Gewöhnlich haben Wissenschaftshistoriker die Gebäude naturwissenschaftlichen Forschens, seine „Behausung“, unbeachtet gelassen; das Interesse galt statt dessen kognitiv-theoretischen Aspekten und, in geringerem Maße, auch der instrumentellen Grundlage wissenschaftlicher Bestrebungen. Schon seit langem ist beispielsweise die große Bedeutung des Fernrohrs und der Luftpumpe bekannt. ${ }^{3}$ Die Architektur der Bauwerke, in denen Naturwissenschaft tatsächlich betrieben wurde und wird, fand jedoch im groBen und ganzen wenig Interesse und wurde an die Lokalgeschichtsschreibung verwiesen ${ }^{4}$. Erst seit kurzem werden Gebäude zunehmend als wichtige Faktoren für unsere Bemühungen erkannt, die Entwicklung der modernen Naturwissenschaften zu verstehen. In einem neueren Aufsatzband zur Wissenschaftsarchitektur heißt es, dass ,,buildings of science literally and figuratively configure the identity of the scientist and the scientific field“ und dass ,architecture and science define one another through their encounter" $"$.

Schließlich genügen Bauwerke nicht lediglich den praktischen Erfordernissen ihrer Bewohner,

\footnotetext{
2 Livingstone, David N.: Putting Science in its Place. Geographies of Scientific Knowledge, Chicago and London, 2003. See also Withers, Charles W.J.: „The geography of scientific knowledge“, in: Göttingen and the Development of the Natural Sciences, hrsg. von Nicolaas A. Rupke, Göttingen 2002, S. 9-18.

3 Oft zitiert wird Shapin, Steven/ Schaffer, Simon: Leviathan and the Air-Pump: Hobbes, Boyle, and the Experimental Life, Princeton 1985.

${ }^{4}$ Ein gutes Beispiel für derartige Lokalgeschichten ist Riecke, Eduard et al.: Die physikalischen Institute der Universität Göttingen, Leipzig und Berlin 1906. Für eine lokalgeschichtliche Darstellung der ersten Göttinger Sternwarte auf einem der Türme der alten Stadtmauer vgl. Aufgebauer, Peter: „Die Anfänge der Sternkunde in Göttingen“, in: Göttinger Jahrbuch 2002, S. 75-92.

5 Galison, Peter: „Buildings and the subject of science“, in: The Architecture of Science, hrsg. von Peter Galison und Emily Thompson, Cambridge, MA, 1999, S. 1, 3.
} 
sondern können zu eindrucksvollen Symbolen von Macht werden und denen, die in ihnen leben und arbeiten, eine besondere Autorität verleihen. Offensichtliche Beispiele dafür sind Tempel, Kathedralen und Paläste. Die Lage derartiger Gebäude - auf einem Berggipfel, im Herzen einer Stadt usw. - , ihre Dimensionen und ihre architektonischen Merkmale - etwa Kuppeln, Türme und dergleichen - sind in vielen Fällen Ausdruck der gesellschaftlichen Stellung, die ihre Bewohner einnehmen. Und obwohl sie nicht in erster Linie für die Pflege der Naturwissenschaften errichtet wurden, sind sie vielen verschiedenen Geistesaktivitäten förderlich, darunter auch naturwissenschaftlichen. Tatsächlich gehören im christlichen Abendland Kathedralen $\mathrm{zu}$ den ersten Stätten, an denen astronomische Beobachtungen gemacht wurden, und wie John Heilbron in einer höchst originellen Studie beschreibt, dienten Gotteshäuser auch als Sonnenobservatorien. ${ }^{6}$ Ebenso ist die Rolle des Herrscherhofes als Schauplatz naturwissenschaftlicher Debatten und der Rezeption naturkundlicher Kenntnisse untersucht worden. ${ }^{7}$ Universitätsgebäude machen keine Ausnahme von der Regel, dass architektonische Strukturen ihren Bewohnern besonderes Ansehen verleihen können, und manches alte akademische Traditionsgebäude gibt Zeugnis vom Überlegenheitsanspruch der Professorenschaft und vielleicht auch von der Form und vom Inhalt der Vorlesungen.

Ebenso wenig machen Gebäude eine Ausnahme, die für die Naturwissenschaften errichtet wurden, so dass sich auch in ihrer Errichtung und ihren architektonischen Merkmalen grundsätzliche Ansichten über die Stellung der Naturwissenschaftler in der Gesellschaft ausdrücken. Außerdem können ihre äußere Gestalt und ihre innere Raumaufteilung das, was in ihnen abläuft, strukturieren und definieren und uns Auskunft darüber geben, wie naturwissenschaftliche Forschung sich abgespielt hat. Die ältesten naturwissenschaftlichen Architekturdenkmale haben meist eine Verbindung zur Medizin; zu ihnen gehören Krankenhäuser, Irrenanstalten, botanische Gärten, Gewächshäuser und, in Göttingen, die Entbindungsklinik, das 1785-1790 errichtete

\footnotetext{
${ }^{6}$ Heilbron, John: The Sun in the Church, Cathedrals as Solar Observatories, Cambridge, MA, 1999.

${ }^{7}$ Biagioli, Mario: Galileo Courtier, The Practice of Science in the Culture of Absolutism, Chicago 1993.
}

Accouchierhaus. ${ }^{8}$ Auch die anatomischen Theater haben in der aktuellen Literatur Beachtung gefunden, darunter so herausragende Beispiele wie diejenigen in Bologna, ${ }^{9}$ Leiden und Uppsala. Weiterhin hat die Beschäftigung mit der ,Alltagsgeschichte“ naturwissenschaftlichen Arbeitens, besonders in den Laboratorien des 19. und 20. Jahrhunderts, dazu beigetragen, das Interesse an der Architektur naturwissenschaftlicher Stätten zu erhöhen. ${ }^{10}$

Das neunzehnte Jahrhundert war die Epoche, in der die Errichtung von Gebäuden für die $\mathrm{Na}$ turwissenschaften in großem Stil begann, und die palastähnlichsten von ihnen waren die Naturkundemuseen. Obwohl es Museen dieser Art in Form von „Naturalienkabinetten“ schon seit der frühen Neuzeit und sogar davor gegeben hat, entstanden größere Gebäude zu dem Zweck, derartige Sammlungen zu beherbergen und ihre Vergrößerung anzuregen, in den meisten Fällen erst im neunzehnten Jahrhundert. ${ }^{11}$ Damals bekamen in den Hauptstädten der westlichen Welt und auf dem Gelände vieler führender Universitäten „Tempel der Natur“ und „Kathedralen der Naturwissenschaften“ ihren Platz neben den älteren architektonischen Komplexen. Diese Bauwerke, ihre genaue Lage, ihre Größe, ihr Stil und ihre bekanntesten Exponate erlangten eine hohe öffentliche Bedeutsamkeit und wurden Objekte von Bürger- und Nationalstolz. ${ }^{12}$ Die wichtigsten nationalen Naturkundemuseen, etwa

\footnotetext{
${ }^{8}$ Trotz neuerer Forschungen zu diesem Thema ist das Standardwerk zur Krankenhausarchitektur noch immer Thompson, John D./ Goldin, Grace: The Hospital, A Social and Architectural History, New Haven 1975.

${ }_{9}^{9}$ Die bedeutende Rolle der italienischen anatomischen Theater zeigt Biagioli, Mario: „Scientific revolution, social bricolage, and etiquette", in: The Scientific Revolution in National Context, hrsg. von Roy Porter und Mikulás Teich, Cambridge 1992, 11-54.

${ }^{10}$ Vgl. z.B.: Laboratory Life. The Construction of Scientific Facts, hrsg. von Bruno Latour und Steve Woolgar, Princeton 1986

${ }^{11}$ Ein früheres Beispiel ist das 1769 eröffnete Museum Fridericianum in der $50 \mathrm{~km}$ südwestlich von Göttingen gelegenen hessischen Residenzstadt Kassel. Es ist eines der ersten Gebäude der Architekturgeschichte mit der Funktion eines Museums mit Publikumsverkehr und war bestimmt ,zur Aufnahme der Kabinette für Naturgeschichte, Mathematik, Physik, Altertümer, Mechanik und Medaillen sowie der öffentlichen Bibliothek", vgl. Schneider, Helmuth: ,'Wahrhaft glückliche Tage'. Kassel und die Antike im 18. Jahrhundert", in: Kassel im 18.Jahrhundert. Residenz und Stadt, hrsg. von Heike Wunder u.a., Kassel 2000, S. 88-102, hier S. 89.

12 Rupke, Nicolaas A.: Richard Owen, New Haven and London 1994, S. 12-105. Forgan, Sophie: „Bricks and bones: architecture and science in Victorian Britain“, in: The Architecture of Science, hrsg. von Peter Gallison und Emily Thompson, Cambridge, MA, 1999, S. 181-208.
} 
in Berlin, London, Paris und Wien, standen im Wettbewerb miteinander. Das Pariser Muséum d'Histoire Naturelle, das aus dem Jardin du Roi entstand, war das erste große Zentrum der naturwissenschaftlichen und insbesondere der biologischen Forschung im Europa des neunzehnten Jahrhunderts. ${ }^{13}$ Das Museum für Naturkunde in Berlin wurde erst viel später errichtet, als in der Folge der Reichsgründung von 1871 die neue Reichshauptstadt Berlin einen enormen Bauboom erlebte. ${ }^{14}$ Innerhalb des britischen Weltreiches entwickelte sich eine zusätzliche Rivalität zwischen den Museen des Mutterlandes und denen in den Kolonien. Von Melbourne bis Montreal wurden diese Institutionen zu Zentren intellektueller Aktivität und förderten das Entstehen eines kulturellen Selbstvertrauens in den weit von England entfernten britischen Besitzungen. ${ }^{15}$

In Großbritannien sah man drei Institutionen als die Naturkundemuseen schlechthin an: das hauptstädtische British Museum (Natural History) in South Kensington, gegründet von Richard Owen (1804-1892); das University Museum in Oxford, entstanden aus den geologischen Sammlungen William Bucklands (1784-1856); und das Museum of Science and Art in Edinburgh. Ihrer Baugeschichte hat Carla Yanni eine ausgezeichnete Studie gewidmet. ${ }^{16}$ Am besten untersucht ist die Baugeschichte des Museum of Natural History in London. ${ }^{17}$ Es verfügte über besonders reiche Sammlungen an Exponaten aus den überseeischen Kolonien, beispielsweise Australien und Neuseeland. Aber nicht nur seine naturhistorischen Bestände sind eine bedeutende Informationsquelle über die Kultur der Naturwissenschaften seiner Epoche, sondern auch die Gestaltung dieses Museums. Seine Lage nicht in

${ }^{13}$ Laissus, Yves : Le Muséum national d'histoire naturelle, Paris 1995. Vgl. auch Limoges, Camille: „The development of the Muséum d'Histoire Naturelle of Paris, c. 1800-1914“", in: The Organization of Science and Technology in France 1808-1914, hrsg. von Robert Fox und George Weisz, Cambridge 1980, 211-240.

${ }^{14}$ Graefrath, Robert: „Zur Entwurfs- und Baugeschichte des Museums für Naturkunde der Universität Berlin“, in:

Wissenschaftliche Zeitschrift der Humboldt-Universität zu Berlin, R. Math./Nat.wiss. 38 (1989), S. 279-286.

15 Sheets-Pyenson, Susan: Cathedrals of Science, The Development of Colonial Natural History Museums during the Late Nineteenth Century, Kingston and Montreal 1988.

16 Yanni, Carla: Nature's Museums: Victorian Science and the Architecture of Display. Baltimore 1999.

${ }^{17}$ Speziell zur Architektur vgl. Girouard, Mark: Alfred Waterhouse and the Natural History Museum, London 1981.
Bloomsbury im Zentrum Londons, sondern in South Kensington auf dem Gelände der Weltausstellung von 1862, war ein Hinweis auf die enge Verbindung der Sache der Naturwissenschaften mit den liberalen, am Unternehmertum orientierten Reformen William Gladstones (1809-1898). Die gewaltigen Ausmaße des Gebäudes, die von dem Konservativen Benjamin Disraeli (1804-81) und seinen Torys heftig kritisiert wurden, spiegelten das Streben Owens und vieler seiner Wissenschaftlerkollegen nach einem sozialen Status wie dem der traditionellen kulturellen Führungsgruppen - des Adels, der Geistlichkeit und der Judikative. Außerdem verwies der gotische Stil der Architektur auf die traditionelle Verbundenheit der anglikanischen Naturwissenschaft mit der britischen „natural theology", während die zentrale Halle des Museums, besonders ihre kathedralenartigen Gewölbe, auf die sozio-religiösen Ansprüche Owens hindeuteten, der davon überzeugt war, dass Naturwissenschaftler im Auftrage der göttlichen Wahrheit handeln. Die innere Raumaufteilung in Ausstellungsbereiche, Laboratorien, Büros usw. war Teil einer Debatte darüber, wie Forschung abläuft, und über den Stellenwert des funktionalistischen im Vergleich mit dem morphologischen Ansatz bei der Erforschung der Vielfalt des Organischen. ${ }^{18}$

Auch in Göttingen war das neunzehnte Jahrhundert die Epoche, in der man begann, für die Naturwissenschaften Gebäude von einer gewissen architektonischen Pracht zu errichten. Schon in der zweiten Hälfte des vorangehenden Jahrhunderts hatte es Einrichtungen für naturwissenschaftliche Forschungen gegeben, aber in den Privathäusern von Professoren. Ein Beispiel dafür ist das Chemische Laboratorium, entstanden 1783, das ein Bestandteil des Hauses war, in dem von 1784 bis 1804 Johann Friedrich Gmelin (1748-1804) wohnte. Für Friedrich Wöhler (1800-1882), der 1836 nach Göttingen gekommen war, wurde 1842 ein neues reines Laborgebäude errichtet und 1858-1860 erweitert. In einem Gebäudeflügel des alten Universitätskomplexes im Paulinerkloster entlang des Papendieks, ursprünglich für Professorenwohnungen genutzt,

\footnotetext{
18 Rupke (Anm 12). Vgl. auch Rupke, Nicolaas A.: „The road to Albertopolis: Richard Owen (1804-92) and the founding of the British Museum of Natural History", in: Science, Politics and the Public Good: Essays in Honour of Margaret Gowing, hrsg. von Nicolaas A. Rupke, London, 1988, S. 63-89.
} 
waren 1793 das Physikalische Kabinett und das Physiologische Institut und wenig später auch das Akademische Museum (1796) eingerichtet worden. Ein vollwertiges Naturhistorisches $\mathrm{Mu}-$ seum entstand zwischen 1873 und 1877, d.h. wie das Berliner Museum für Naturkunde während der frühen Jahre des bismarckschen Kaiserreichs. Die ersten architektonisch anspruchsvollen, eigens für naturwissenschaftliche Zwecke errichteten Gebäude in Göttingen waren die Sternwarte (1802-1816) und das Theatrum Anatomicum (1827-1829; erweitert 1885-1900; zerstört bei einem Bombenangriff 1945).

Obwohl die Pariser Sternwarte, erbaut zwischen 1667 und 1672, und das Royal Observa-tory in
Greenwich von $1675 \mathrm{zu}$ den frühen architektonischen Stätten der Naturwissenschaften gehören, haben sie bisher weit weniger historiographische Aufmerksamkeit erfahren als beispielsweise die nationalen Naturkundemuseen. ${ }^{19}$ In Deutschland ist die Göttinger Sternwarte ein Meilenstein bei der Institutionalisierung naturwissenschaftlicher Forschung und bei der Entwicklung des akademischen Forschungsimperativs. Das Borhecksche Manuskript ist eine bedeutende Quelle für das Verständnis der Göttinger Sternwarte als einem der „Räume des Wissens“" und liefert Material für die Beantwortung der allgemeineren Frage nach der „Behausung“ astronomischer Forschung und deren Bedeutung.

${ }^{19}$ Vgl. aber auch Morton-Gledhill, Rowan I.: ,The Architecture of Astronomy in the British Isles: A General Study“, in: Vistas in Astronomy 32 (1989), S. 253-83. 


\section{Astronomical Precision in the Laboratory: The Role of Observatory Techniques in the History of the Physical Sciences}

\section{by David Aubin, Paris}

In the summer of 1829, Adolphe Quetelet who was planning to set up an observatory of his own in Brussels toured Germany to gather information from its main astronomers. Influenced by his mentors Alexander von Humboldt and François Arago, Quetelet had set out to measure the magnetic field of the earth in the several locations he visited. One day, he called on Carl Friedrich Gauss in his Göttingen observatory. The next day, they installed instruments in the garden of the observatory, far from any piece of iron to avoid perturbation on the delicate setup. The Göttingen astronomer was then sceptical of Humboldt's grand ambition of turning the study of geomagnetism into a global precision science. One year earlier he had had the opportunity to perform some experiments with Humboldt in Berlin and he had not been impressed by the quality of these measurements.

That summer day of 1829, both Gauss and Quetelet held a chronometer in their hand and timed the oscillations of a magnetic needle placed between them. At their utmost surprise, their respective measurements for the duration of a hundred oscillations differed by less than a tenth of a second. "But these observations," Gauss apparently exclaimed, "have the precision of astronomical observations."1

\footnotetext{
${ }^{1}$ Adolphe Quetelet, Sciences mathématiques et physiques an commencement du XIX' siècle (Brussels: Mucquart, 1867), 646. See Gauss to Olbers, 12 October 1829, in C. F. Gauss and H. W. M. Olbers, Briefwechsel, 3 vols. (Hildesheim/New York: Georg Olms, 1976), 2:525. "Bei Beobachtung der Schwingungsdauer einer Nadel lässt sich eine Schärfe errei-
}

Astronomers have early on insisted on the precision of their measurements and computations. The transformation of industrial and scientific cultures in the nineteenth century has been traced in part to the rise of "the values of precision" and laboratories in universities and industries have traditionally been seen as central locations in this process. The observatory is arguably equally important, if only because a number of these values already pervaded observatory culture by the end of the eighteenth century. ${ }^{2}$

Viewed from today, the eclecticism of observatory scientists in the first part of the nineteenth century may seem puzzling. Famous for his social theory of the average man, Quetelet studied with just as much devotion and enthusiasm shooting stars, the influence of the moon on climate, probability theory, demography, or criminality. Similarly, one is often surprised to learn that Gauss, who was one of the greatest mathematicians of his time, spent several years to observe stars and comets, to triangulate the state of Hannover, or to perform delicate measurements of the earth magnetic field. ${ }^{3}$

At the heart of the observatory's material culture lay a family of scientific instruments, most of them, though by no means all, optical. The telescopes, polariscopes, spectroscopes, magnetometers, clocks, thermometers, hydrometers populating the observatory expressed the central concern of their users: to achieve the highest possible level of precision in the (mostly quantitative) measurement of celestial phenomena. Astronomy was the first precision science. ${ }^{4}$

chen, die ich selbst früher für unglaublich gehalten haben würde" (ibid., 2:588).

2 M. Norton Wise, ed., The V alues of Precision (Princeton, NJ: Princeton Univ. Press, 1995). About observatory sciences, see David Aubin, "The Fading Star of the Paris Observatory in the Nineteenth Century: Astronomer's Urban Culture of Circulation and Observation," Osiris 18 (2003), 79-100; and David Aubin, Charlotte Bigg, and H. Otto Sibum, eds., The Heavens on Earth: Observatory Techniques in the Nineteenth Century (forthcoming).

${ }^{3}$ G. Waldo Dunnington, Carl Friedrich Gauss: Titan of Science (New York, Hofner, 1955); Tord Hall, Carl Friedrich Gauss: A Biography, trans. Albert Froderberg (Cambridge, Mass.: MIT Press, 1970).

${ }^{4}$ Historians of astronomy can be counted among those who have pioneered the exploration of nontheoretical issues in the history of science, in particular paying considerable attention to instruments of high precision and their makers. See for example Henry C. King, The History of the Telescope (Mineola, NY: Dover 2003 [1955]); Allan Chapman, Dividing the Circle: The Development of Critical Angular Measurement in Astronomy, 1500-1850, 2nd ed. (Chichester: John Wiley \& Sons, 1995). 


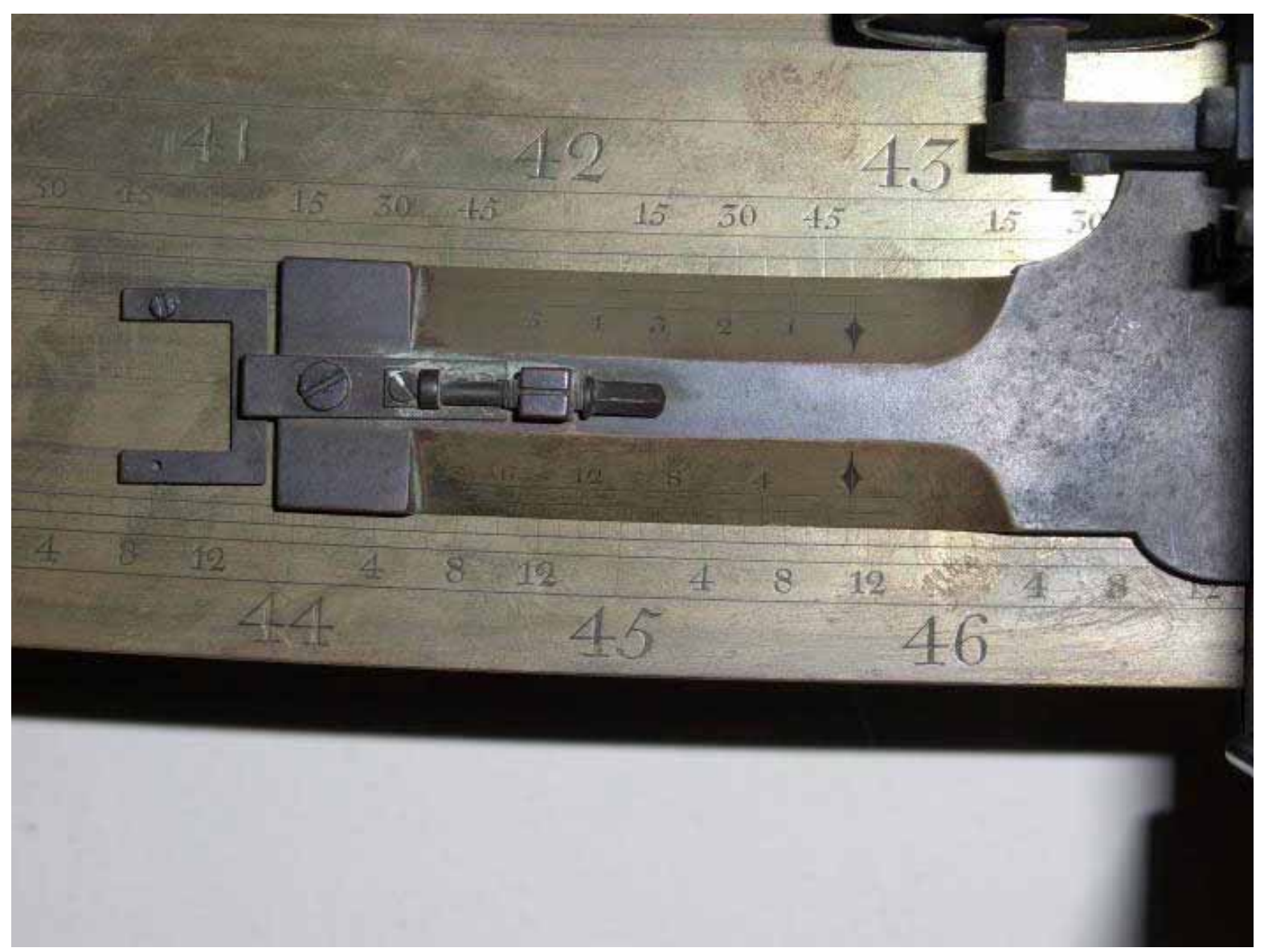

Abb. 9: Detail des Teilkreises mit Nonius auf dem Birdschen Mauerquadranten von 1756, der bis 1816 in der alten und danach in der neuen Sternwarte benutzt wurde (s. Abb. 25). Oben sind die Winkelgrade in Bogenminuten, unten in 16-tel Grad unterteilt. Der Nonius gestattete Messungen mit einer Genauigkeit von einigen Bogensekunden. Das Instrument ist heute nicht mehr voll funktionsfähig (Photo K. Reinsch, Universitäts-Sternwarte).

Precision relied on an array of techniques that were rooted in the culture of the observatory. Around 1800, there were few places as entirely devoted to the pursuit of research in the physical sciences as the observatory. In Paris, Greenwich, and elsewhere, maritime nations maintained large buildings, expensive instruments, and qualified staff for the advancement of knowledge, the improvement of maps, the computation and publication of tables and almanacs, and the development of navigational methods. ${ }^{5}$ During the French revolution, observatory scientists were entrusted with the determination of the new

5 The search for a reliable method for longitude determination at sea looms large in the early history of observatories. Cf., in particular, Derek Howse, Greenwich Time and the Discovery of the Longitude (Oxford: Oxford Univ. Press, 1980); William J. H. Andrewes, ed., The Quest for Longitude (Cambridge, Mass.: Harvard Univ. Press, 1996); Guy Boistel,

L'Astronomie nautique an XVIIIe siecle en France: tables de la Lune et longitudes en mer, Ph.D. thesis (Université de Nantes, 2001); and Vincent Jullien, ed., Le Calcul des longitudes. Un enjeu pour les mathématiques, l'astronomie, la mesure du temps et la navigation (Rennes: Presses univ. de Rennes, 2002). metric units. ${ }^{6}$ Nineteenth-century observatory scientists were at the forefront of scientific networking. In 1800, an international group of astronomers led by Franz Xaver von Zach had set up the Vereinigte Astronomische Gesellschaft to look for what they thought was a missing planet between Mars and Jupiter. They established an early international vehicle for communication by publishing regular observations in Zach's Monatliche Correspondenz (1800-1814), and later in Schumacher's Astronomische Nachrichten (from 1821). ${ }^{7}$

${ }^{6}$ Ken Alder, The Measure of All Things: The Seven-Year Odyssey that Transformed the World (London: Little, Brown, 2002).

7 The history of astronomy's early professionalization is well documented. For Germany, see Jürgen Hamel, "H. C. Schumacher: Zentrum der internationalen Kommunikation in der Astronomie und Mittler zwischen Dänemark und Deutschland" and Gudrun Wolfschmidt, "Internationalität von der VAG (1800) bis zur Astronomischen Gesellschaft," W. D. Dick and J. Hamel, eds., Astronomie von Olbers bis Schwaryschild, Nationale Entwicklungen und internationale Beziebungen im 19. Jabrbundert/ Acta Historia Astronomiae, 14, 89120 and 182-203; Dieter B. Herrmann, "Das Astronomentreffen im Jahre 1798 auf dem Seeberg bei Gotha," Archive for the History of Exact Sciences 6 (1969/1970), 326-44. About 
By 1800 , the observatory, therefore, had given rise to an epistemological space defined by a coherent set of techniques in precision, standardization and networking: the design and manipulation of delicate instruments, the material and mathematical treatment of numbers extracted from observation, and the social management of qualified personnel working together towards common aims, either inside one particular observatory or in collaboration across national boundaries. Borheck's manuscript is a striking testimony to the fact that little was left to improvisation when it came to ensure that an observatory yielded only the most precise data. Borheck divided his memoir into three parts concerned with, respectively, the location of the observatory, its instruments, and its building. In all cases, his utmost concern to which all others were subservient was that the best possible, most precise observational data could be produced in the observatory. Equally important was the willingness of European states, and especially German ones, to allocate the required funds to this enterprise. As Friedrich Bessel wrote Gauss when the Prussian government agreed to set up an observatory in Königsberg:

Dennoch kostet das Gebäude nahe an 20000 Thaler; der Grund 6000 Thaler; die Instrumente etwa 4000 Thaler. Es kann sonderbar scheinen, das in den jetzigen Zeiten so viel an eine Sternwarte verwandt wird; allein die Zeiten, wo das Militair alles wegnahm, sind vorbei, und so wird denn das lebhaftere Interesse an wissenschaftlichen Sachen erklärlicher. ${ }^{8}$

Precision attracted Gauss's attention to astronomy. ${ }^{9}$ Few of his contemporaries excelled as he did in the several sides of astronomical work, from the most theoretical studies to routine observation. Having studied astronomy in Göttingen in 1795-98, assisted Lieutenant K. L. E. von Lecoq in his geodetic survey of Westphalia, and

the solidarity of German astronomers, see Gauss to Bessel, 5 March 1820, in Carl Friedrich Gauss and Friedrich Wilhelm Bessel, Briefwechsel, 2 vols. (Hildesheim/New York: Georg Olms, 1976), 1:324.

${ }^{8}$ Bessel to Gauss, 10 März 1811, in Briefwechsel, 1:144

${ }^{9} \mathrm{M}$. Brendel, "Über die astronomischen Arbeiten von Gauss," Carl Friedrich Gauss Werke, 11, 2, Abh. 3 (1929), 1 258. Otto Volk, "Astronomie und Geodäsie bei C. F. Gauss," C. F. Gauss: Leben und Werke, ed. Hans Reichardt (Berlin: Haude \& Spenersche, 1960), 207-16; Eric G. Forbes, "The Astronomical Work of Carl Friedrich Gauss (1777-1855)," Historia Mathematica 5 (1978), 167-81; also in Sterne und Weltraum 16 (1977), 158-66. visited Zach at the Seeberg Observatory (Gotha), Gauss was struck by the announcement in Zach's journal for September 1801 of the discovery of a new planet (Ceres) by Giuseppe Piazzi. Before disappearing behind the Sun, the planetoid had been observed for 41 days only. This short duration made it difficult to compute the size and shape of its orbit and thus to predict where and when the faint light deflected by Ceres would be visible again. Gauss saw a golden opportunity to demonstrate his mathematical skills to the astronomical community when he calculated the orbit of Ceres on the basis of three observations only. On 1 January 1802, Gauss's approach was vindicated when, relying on his computations, Zach sighted the planet again.

Early 19th-century German astronomers, von Zach, Olbers and Gauss, among others, were drawn to emphasize the need of furthering the precision of astronomical observation. Variations in brightness, misrecordings and misprints, and errors in the reduction of data marred extent star catalogues and made them acutely aware of the need to rework older catalogues introducing more precise corrections for astronomical refraction, stellar aberration, and the precession of equinoxes. Olbers made a chance discovery of a second minor planet (Pallas), and in September 1804, Göttingen astronomer Karl Ludwig Harding spotted a third one (Juno). As new data on minor planets gathered, Gauss set out to compute the perturbations due to the gravitational attraction exerted by Jupiter on them. From this work, he developed the least-square method which enabled him to make use of all-not merely three-observed positions of a planet. ${ }^{10}$

From early on, Gauss felt that observations were as useful to his theoretical undertaking as his theory in assisting observation. ${ }^{11}$ After having been unsuccessful in his bid for an observatory in Brunswick, Gauss was attracted to Göttingen by the promise of directing a state-of-the-art observatory: "Sie wissen, dass in Göttingen ein Observatorium erbaut wird, wenigstens der Absicht nach so gut, wie irgend eines in der Welt ist." "When he moved to Göttingen Gauss began to observe minor planets regularly in the old observatory of Tobias Mayer.

\footnotetext{
${ }^{10}$ See Oscar B. Sheyhin, "C. F. Gauss and the Theory of Errors," Isis 20 (1979), 21-72.

11 About theoretical vs. practical astronomy, see Bessel to Gauss, 10 July 1820, in Briefwechsel, 1:358; and Gauss's reply, 362. 12 Olbers to Gauss, 12 November 1802, in Briefwechsel 1:107.
} 
He used Mayer's 6-foot mural quadrant, a pendulum clock made by John Stelton and an achromatic refracting telescope from the John \& Peter Dollond firm equipped with micrometers to measure small angular distances from neighboring stars with great precision. Although he made good use of them, Gauss knew that these instruments were no substitute to a meridian transit circle which he ordered from Johann Georg Repsold in Hamburg. Custom-made for Gauss and delivered in 1818, this instrument yielded absolute measurement with respect to celestial coordinates whereas the Dollond telescope could only give relative positions with respect to neighboring stars. From his arrival at Göttingen, Gauss constantly endeavored to equip his observatory with the latest instrumental technology. He obtained from the Munich workshop of Reichenbach a new meridian circle to replace Repsold's, a Liebherr clock to replace Stelton's, a repeating circle and a theodolite.

The observatory's culture of precision had a wide-ranging influence on scientific practice. The crusade undertaken by Humboldt to survey the magnetic field of the Earth provides an example of how observatory techniques were adopted for electromagnetic research. In 1828, Humboldt built a small magnetic observatory in Berlin and initiated a program of coordinated observation at various locations at prearranged times. This required a precise knowledge of time and of the geographical location determined by astronomical means. Gauss took a major part in Humboldt's survey. Mathematical equations had previously been used to account for electromagnetic phenomena, but Gauss was arguably the first to quantify them. ${ }^{13}$

By the late $18^{\text {th }}$ century, it had been recognized that the period of oscillation of a suspended needle was inversely proportional to the square root of the magnetic field. ${ }^{14}$ But such measurements were relative since the intensity of the field could not be separated from the magnetic moment. In his great contribution, "Intensitas vis

\footnotetext{
13 Olivier Darrigol, Electrodynamics from Ampère to Einstein (Oxford: Oxford Univ. Press, 2000) and Christa Jungnickel and Russel McCormmach, Intellectual Mastery of Nature: Theoretical Physics from $\mathrm{Obm}$ to Einstein, 2 vols. (Chicago: Chicago Univ. Press, 1986).

${ }^{14}$ Hans Falkenstein, "Die wesentlichsten Beiträge von C. F. Gauss aus der Physik," C. F. Gauss: Leben und Werke, ed. Hans Reichardt (Berlin: Haude \& Spener, 1960), 232-51; G. D. Garland, "The Contributions of Carl Friedrich Gauss to Geomagnetism," Historia Mathematica 6 (1979), 5-29.
}

magneticae terrestris ad mensuram absolutam revocata," read at the Royal Society of Göttingen on 15 December 1832, Gauss explained that a second experiment could be performed that gave out an absolute measurement of the field. ${ }^{15}$ This was the first non-mechanical quantity to be expressed in terms of mass, length and time. Gauss explained to Olbers:

\section{Ich beschäftige mich jetzt mit dem Erdmagnetismus, namentlich mit einer absoluten Bestimmung von dessen Intensität. (...) So wie man ₹. B. von Geschwindigkeit nur durch Ansetzung einer Zeit und eines Raums einen klaren Begriff geben kann, so, finde ich, muss zur voll- ständigen Bestimmung der Intensität des Erdmagnetismus angegeben werden 1) ein Gewicht $=p$, 2) eine Linie $=r$, und dann man kann den Erdmagnetismus durch $\sqrt{p} / r$ ausdrücken. ${ }^{16}$}

But more than the pleasure of finding out new facts about the earth magnetic field, what truly attracted Gauss's interest to geomagnetism was the prospect of modelling this area of science more thoroughly on astronomy. After the mechanics of moving bodies and optics, electrodynamics would be the next area of physics to be expressed in the form of analytical laws submitted to the test of high-precision measurement:

Fast noch wichtiger aber, als der glänzende Zuwachs unerwarteter Thatsachen, die in diesen Gebieten entdeckt sind [the work of Oersted, Ampère, Arago and Faraday], ist der Umstand, dass auch hier die Versuche einer frühere weit überflügelnden Schärfe, und ihre einfachen Grundgesetze einer wahrhaft mathematischen Präcision fähig werden, so dass die Scheidewand zwischen eigentlich sogenannter Physik und angewandter Mathematik auch hier (wie längst in der Bewegungslehre und Optik) zu sinken, und die tiefer eingreifende Bearbeitung dem $M a$ thematiker anheim zu fallen anfängt. ${ }^{17}$

Characteristically for an astronomer, Gauss gave thorough descriptions of the instruments he had taken from the observatory panoply and adapted to geomagnetic surveys. His addition of a telescope to Gambey's dip magnetometer allowed the scientist to observe the needle at a distance and avoid its disturbance though air currents and

15 Werke V, 79ff., Annalen der Physik (1833). Ostwalds Klassiker der exakten Wissenschaften 53 (Leipzig: Akademische Verlagsgesellschaft, 1894).

16 Gauss to Olbers, 18 Februar 1832, 2:584-585.

17 Gauss, [Magnetismus und Galvanismus : Amtlicher Bericht], (Gauss an Königliches Universitäts-Curatorium, 29. Januar 1833), Werke 11:55-8. 
bodily heat. With his bifilar magnetometer, Gauss claimed that "the horizontal part of the earth's magnetic field can now be observed as precisely as the stars in the sky."18 In 1838, Gauss published the "Allgemeine Theorie des Erdmagnetismus," in which he expressed the potential of the field in terms of a sum of spherical harmonic functions. ${ }^{19} \mathrm{He}$ then went on to compare the results of his theoretical investigations with observations taken all over the earth.

As soon as he became interested in magnetism and after Wilhelm Weber was hired as physics professor by the University in Göttingen, Gauss geared his effort at setting up a new laboratory, a "magnetic observatory," where such studies could be performed. "Vielleicht wird unser Gouvernement, wenn die Geldklemme nicht zu gross ist, demnächst nicht abgeneigt sein, ein eigenes magnetisches Häuschen, worin gar kein Eisen ist, zu errichten." ${ }^{20}$ In his petition to the Curatorium, Gauss insisted that astronomical precision required thorough mathematical studies, expensive instruments, skilled experimenters, and a specific space devoted to their manipulations:

$V$ on jeher schien mir, dass die Apparate, deren man sich für die magnetischen Bestimmungen bedient, sehr unvollkommen, und in einem schreienden Missverbältnisse gegen die Schärfe unserer astronomischen und geodätischen Messungen sind. Ich habe seit etwa 5 Monaten angelegen sein lassen, diesem Uebelstande abzuhelfen, wobei ich gleich Anfangs von einigen schon seit vielen Jahren gehabten Ideen ausging, aber freilich fast jede Woche noch etwas Neues gekommen bin. Gegenwärtig habe ich rwei Apparate fertig (...), womit absolute Dekl. und ibre Aenderungen, Schwingungsdauer etc. mit einer Schärfe gemessen werden können, die gar nichts zu wünschen übrig lässt. Ausgenommen für mich ein angemesseneres Lokal, wo kein Eisen in der Nähe ist und jeder Luftrug abgehalten ist. ${ }^{21}$

Recognizing the need for a specially-designed environment for his experiments, Gauss had an iron-free building set up on the grounds of the astronomical observatory. This was one of the first modern physics laboratories. In Germany, his collaborator Wilhelm Weber wrote to Edward Sabine, "until now there existed only collections of physical instruments without permanent facilities for their use; there were no physical laboratories or observatories."22 The physical laboratory borrowed heavily from the observatory. Before large physical laboratories were established in the 1860s and 1870s, it was common to speak of "physical observatories" and the laboratory building of the Physikalisch-Technische Reichsanstalt was named the Observatorium. ${ }^{23}$

Two years before Quetelet, Jean-Jacques Ampère had also visited Göttingen and its observatory. On April 22, 1827, he wrote to his father Adrien-Marie Ampère that his work on the theory of electromagnetism was greatly appreciated in Germany and that he should send copies of his latest work to the Göttingen library. "I think it is as important for the Germans to learn what concerns the sciences from us as it is useful to us to study there literary criticism and history." 24 A mere decade later, German observatory scientists had much to teach French physicists, not only about the theoretical development of electromagnetism, but also and more importantly about the way in which observatory techniques could be successfully transferred into the physical laboratory.

\footnotetext{
18 Gauss to Olbers, 2 September 1837, in Briefwechsel, 2:649.

${ }^{19}$ Werke V.

${ }^{20}$ Gauss to Olbers, in Briefwechsel, 2:590.
}

\footnotetext{
${ }^{21}$ Gauss to Olbers, 2 August 1832, in Briefwechsel, 2:587.

22 Weber to Sabine, 20 Feb. 1845; quoted in Jungnickel and McCormmach, Intellectual Mastery, 1:77. My emphasis.

23 David Aubin, "Orchestrating Observatory, Laboratory, and Field: Jules Janssen, the Spectroscope, and Travel," Nuncius 17 (2003), 143-62.

24 “'Tu devrais réserver une certaine quantité d'exemplaires de ton oeuvre dernière pour Bonn, Goettingue, Weimar et l'Allemagne en général. Je crois aussi important pour les Allemands d'apprendre de nous ce qui concerne les sciences, qu'il nous est utile d'étudier chez eux la critique et l'histoire des différentes littératures." Jean-Jacques Ampère, Correspondance (Paris: Hetzel, 1875), 441-2.
} 


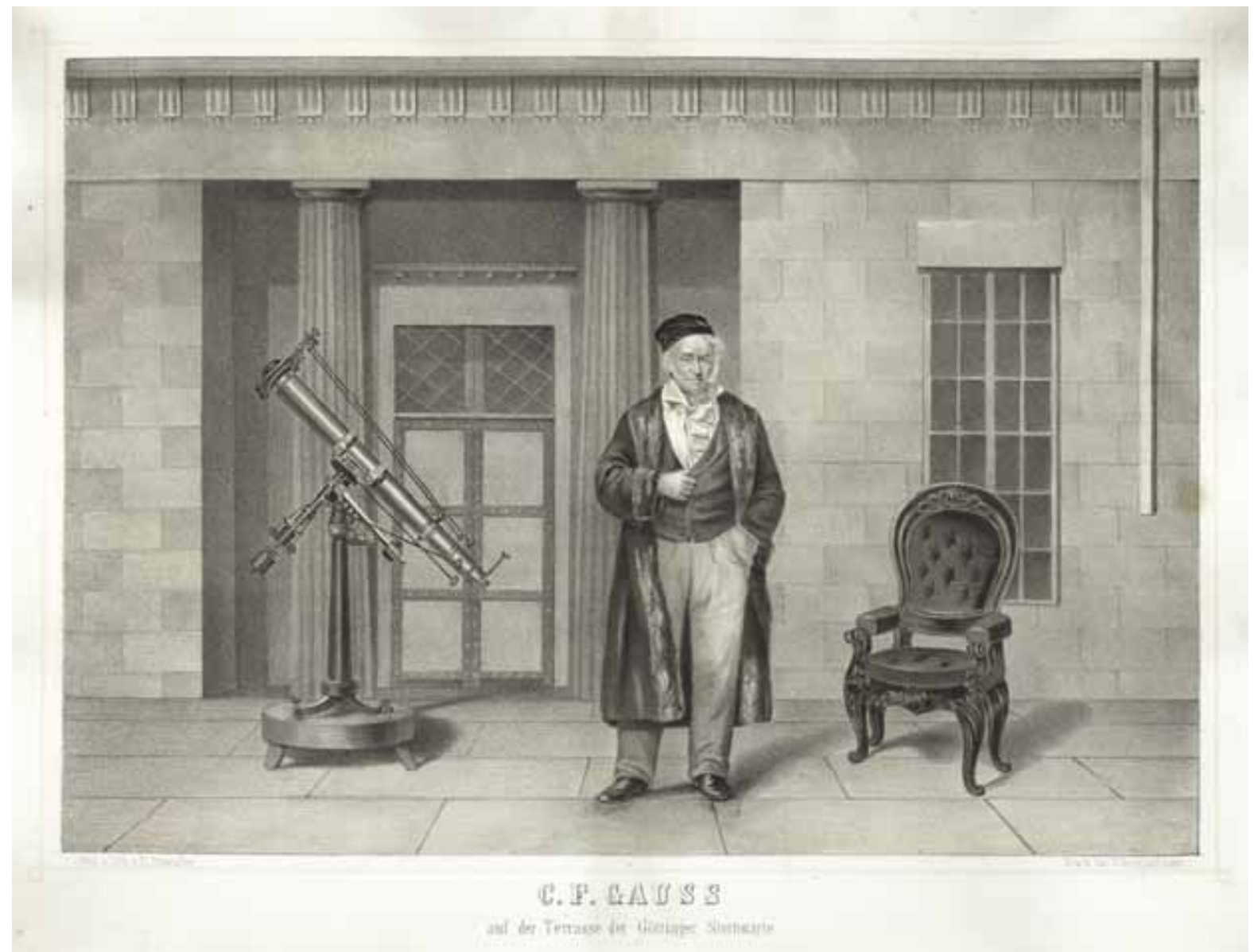

Abb. 10: C. F. Gauß auf der Terrasse der Sternwarte, Lithografie von E. Ritmüller, verlegt bei Vandenhoeck \& Ruprecht in Göttingen, Druck bei H. Honig in Göttingen. Entstanden ist dieser Stich ca. 1850. Auf dem Bild sind Person, Teleskop und Lehnsessel im Verhältnis zum Säuleneingang zu groß dargestellt. Das Teleskop ist ein von Fraunhofer gebautes Heliometer, das Gauß 1814 beschafft hat. Es erhielt 1872 ein neues Stativ und befindet sich in dieser erneuerten Form noch im Besitz der Sternwarte. Es wurde bis 1924 benutzt.

Abb. 11: Fraunhofers Heliometer im Jahre 2005 (Photo K. Reinsch, Universitäts-Sternwarte

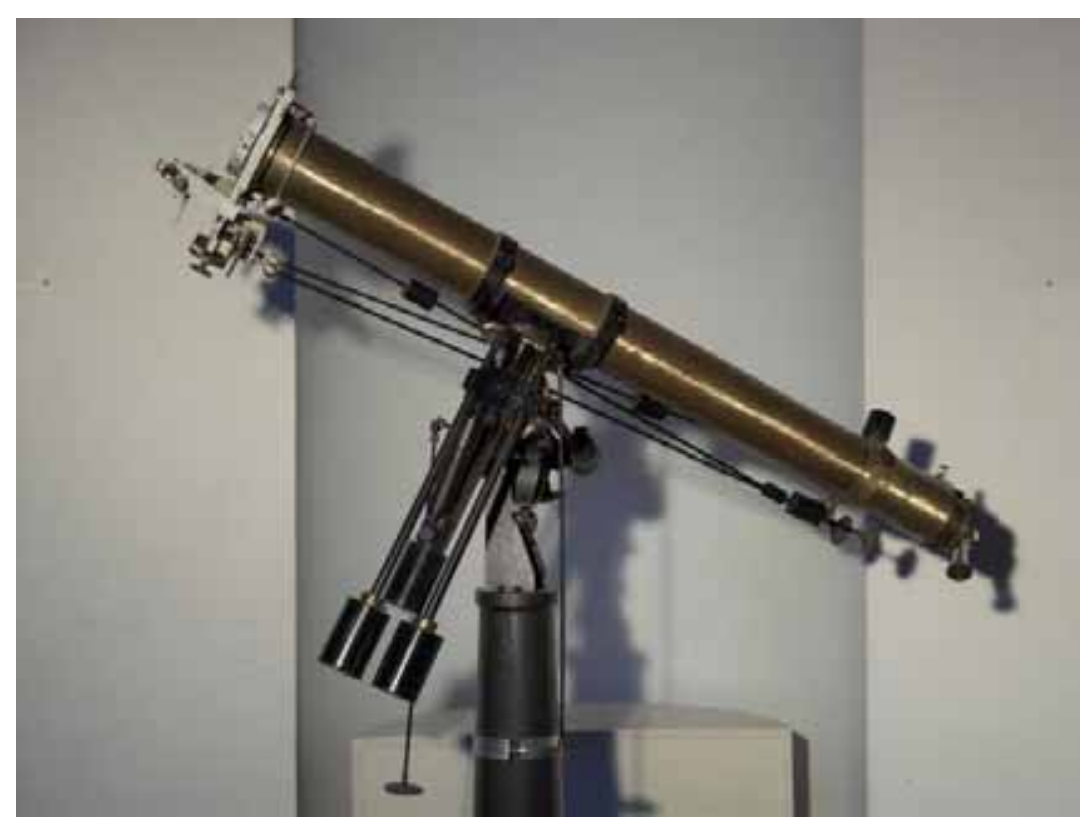




\section{Carl Friedrich Gauß und die Göttinger Sternwarte}

\author{
von Klaus Beuermann, Göttingen
}

Carl Friedrich Gauß wurde 1807 zum ersten Direktor der neuen Göttinger Sternwarte berufen und blieb dies nahezu 48 Jahre lang bis zu seinem Tode am 23. Februar 1855. Der Bau der „Neuen Sternwarte“" vor dem Geismartor und die Berufung von Gauß sind eng verknüpft - allerdings nicht in der Weise, dass der Bau eine Berufungszusage an Gauß wäre. Universität und Regierung verfolgten vielmehr den Bau bereits ab 1791 (Gauß war damals 14 Jahre alt) mit dem Ziel, auch im Fach Astronomie eine wissenschaftlich hervorragende Institution zu schaffen und eine erstrangige Berufung durchzuführen. Im Jahre 1802 schließlich stellte König Georg III. die erforderlichen Mittel zur Verfügung und 1803 wurde der Bau begonnen, aber bald durch die französischen Besetzungen unterbrochen und verzögert.

\section{Die Berufung von Gauß nach Göttingen}

Mit der Bewilligung der Mittel für den Bau konnte die Fakultät auch ernsthaft die Suche nach einem Kandidaten für die Stelle eines ordentlichen Professors und Direktors der Sternwarte aufnehmen. Den Vorschlag Gauß zu berufen unterbreitete der als Astronom bereits berühmte und in wissenschaftlichen Kreisen sehr einflussreiche Bremer Arzt Dr. Wilhelm Olbers ${ }^{1}$ dem Göttinger Historiker Heeren und wohl auch dem

1 Olbers hat u.a. auch Bessel (1784-1846) zur Astronomie gebracht und seine Berufung nach Königsberg bewirkt.
Altphilologen und ständigen Sekretär der Societät (Akademie) der Wissenschaften Christian Gottlob Heyne ${ }^{2}$. In Göttingen wurde dieser Vorschlag sehr freundlich aufgenommen ${ }^{3}$ aber eine Ruferteilung zögerte sich hinaus. Gauß hatte 1802 Rufe nach Landshut und St. Petersburg erhalten, aber die Bedingungen sagten ihm nicht zu und er fühlte sich auch seinem Mäzen, dem Braunschweiger Herzog, verpflichtet. Er lehnte die ergangenen Rufe ab und es entstand die Idee, eine herzogliche Sternwarte in Braunschweig zu errichten. Die französische Invasion von 1803 unterbrach alle diese Aktivitäten und der Krieg von 1806, in dem der Braunschweiger Herzog zu Tode kam, entzog Gauß seine wissenschaftliche Unabhängigkeit und finanzielle Basis. Anfang 1807 erhielt Gauß das bereits mehrfach erneuerte und verbesserte Angebot aus St. Petersburg und im April 1807 fragte Heyne bei Gauß an4, ob er „Göttingen als einen Zufluchtsort betrachten wolle, so lange bis die schrecklichen und noch mehr Schrecklicheres drohenden Zeiten, die eine reguläre Berufung unmöglich machten, vorüber sind". Noch während er sich brieflich mit Olbers beriet, erhielt Gauß im August 1807 den endgültigen Ruf nach Göttingen, den er annahm. Im November 1807 zog Gauß mit seiner ersten Frau Johanna und Sohn Joseph (benannt nach Giuseppe Piazzi, dem Entdecker des Planetoiden Ceres) von Braunschweig nach Göttingen um.

Als Gauß nach Göttingen kam, war dort als hauptamtlicher Astronom bereits Karl Ludwig Harding, der Entdecker des dritten Planetoiden Juno, tätig, der 1805 als a.o. Professor und Inspektor der Sternwarte berufen wurde. Obgleich die Anstellungsurkunde für Gauß vom 25. Juli $1807 \mathrm{ihm}$ die Direktion der Sternwarte gemeinsam mit Harding übertrug und Harding 1812 auch zum ordentlichen Professor ernannt wurde, betrachtete Gauß ihn doch eher als einen Gehilfen ${ }^{5}$. Das Verhältnis war anfangs freundlich, später aber - besonders zu Zeiten der Gradvermessung - gespannt. Die Schwierigkeiten aufgrund der politischen Verhältnisse und die Enge in der alten Göttinger Sternwarte wurden nur durch die Hoffnung auf bessere Zeiten gemildert.

\footnotetext{
2 Brief von Olbers an Gauß vom 25. Dezember 1802.

${ }^{3} \mathrm{M}$. Brendel in „Über die astronomischen Arbeiten von Gauss“, Gauß Werke, Bd. 11,2, S. 21.

${ }^{4}$ Brief von Heyne an Gauß vom 12. April 1807.

5 Wilhelm Olbers, sein Leben und seine Werke, Band 2, Briefwechsel zwischen Gauß und Olbers, Nr. 114.
} 


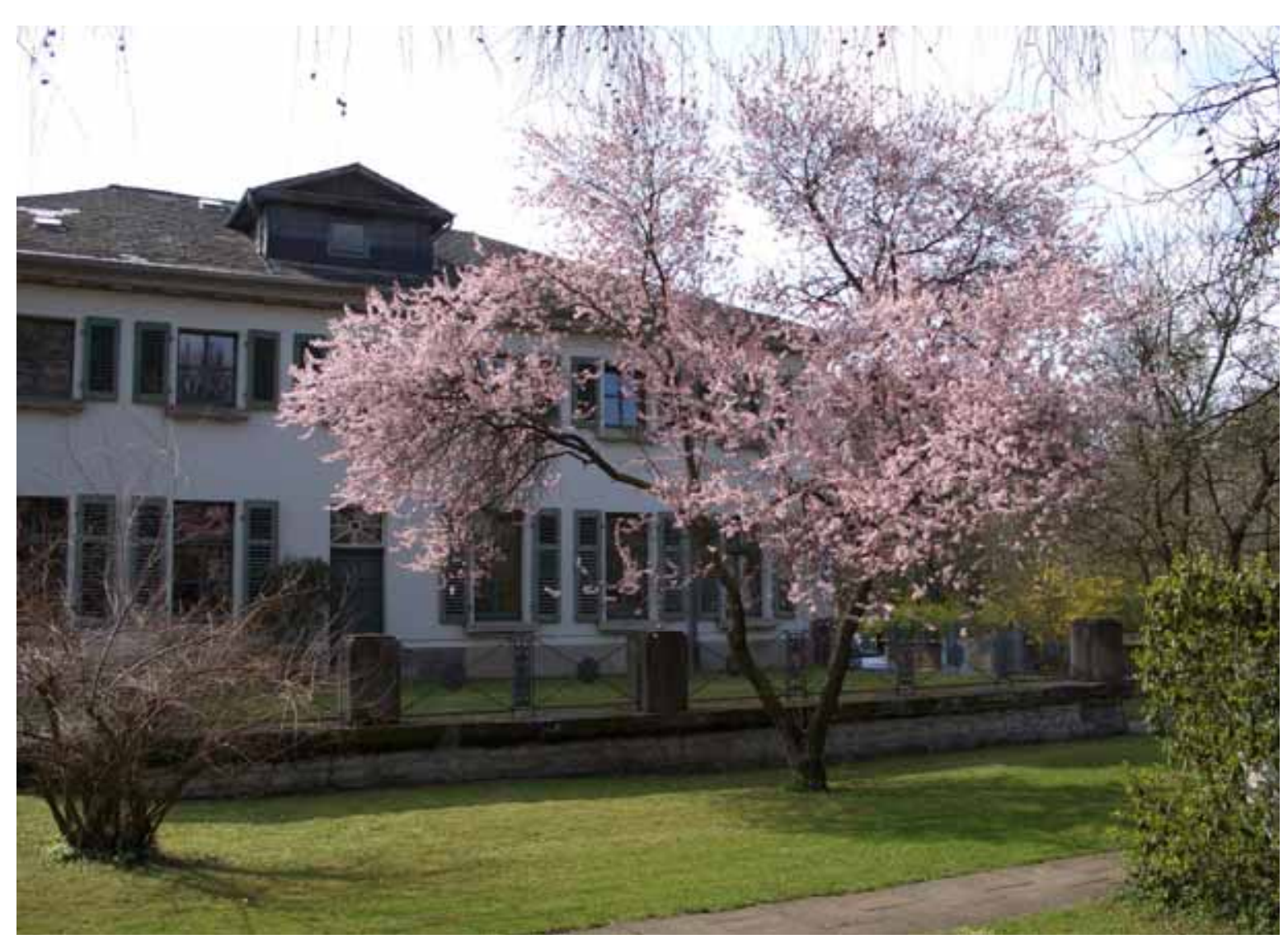

Abb. 12 Der östliche Wohnflügel der Sternwarte, in dem von 1816 an Ludwig Harding wohnte, während Carl Friedrich Gauß mit seiner Familie den Westflügel bezog (Photo K. Reinsch, Universitäts-Sternwarte).

\section{Gauß’ persönliche Lebensverhältnisse in Göttingen}

Nach einer anfänglichen behelfsmäßigen Unterkunft wohnte Gauß mit seiner Familie von 1808 bis 1816 im Eckhaus Kurze Straße/Turmstraße nur wenige Schritte von der alten Sternwarte in der Turmstraße entfernt. In Göttingen wurde 1808 seine Tochter Wilhelmine („Minna“) geboren, benannt nach ihrem Paten Wilhelm Olbers. Ein Jahr später starb seine geliebte Frau Johanna („Hannchen“) nach der Geburt des Sohnes Louis, der nach Ludwig Harding benannt wurde. Louis starb nur wenige Monate später und im Vorjahr war bereits Gauß' Vater in Braunschweig gestorben. Freude und qualvolles Leid liegen hier dicht beieinander. Im folgenden Jahr 1810 heiratete Gauß Friederika Wilhelmina („Minna“) Waldeck, Tochter des Professors Johann Peter Waldeck. Aus dieser Ehe stammen die später in die USA ausgewanderten Söhne Eugen (geb. 1811) und Wilhelm (geb. 1813) sowie die Tochter Therese (geb. 1816), die ihm nach dem Tod seiner zweiten Frau 1831 über 25 Jahre hinweg den
Haushalt führte und bis 1839 Gauß' Mutter pflegte, die aus Braunschweig zur Familie umzog und im hohen Alter von 95 Jahren starb.

Am 17. September 1816 zog die Familie in den Westflügel der gerade fertiggestellten Sternwarte um. Dieser Bau bot ihm immens verbesserte Arbeitsbedingungen, verbunden auch mit der Verantwortung für die instrumentelle Erstausstattung - und einen wunderschönen Spielgrund für die fünf Kinder. Nur wenige Jahre später, 1823, erkrankte seine zweite Frau, war ab 1826 schwer leidend und starb 1831. Er schrieb an den Studienfreund Bolyai: „Wie schwer ein solches Leiden drückt, ... brauche ich Dir nicht zu sagen. Wenn ich ibr nun Glück wünschen darf, von den Leiden endlich befreit zu sein: so füble ich mich selbst dagegen nun so alleinstehend! ${ }^{\circ}$. In dieser Situation suchte er in der Beschäftigung mit der Kristallographie

${ }^{6}$ Nach Horst Michling, Carl Friedrich Gauß, Verlag Göttinger Tageblatt, 3. Aufl. S. 116. 
Ablenkung7 7 bis im Herbst 1831 Wilhelm Weber, 27-jährig, seinen Dienst als Professor für Physik in Göttingen antrat und ihn auf andere Gedanken brachte. Gauß hatte Weber drei Jahre zuvor in Berlin kennen gelernt und dessen Berufung nach Göttingen im Frühjahr 1831 bewirkt. Die Geistesverwandtschaft zwischen den altersmäßig im Vater-Sohn Verhältnis stehenden Persönlichkeiten bestimmte Gauß' Arbeitsleben bis zu Webers Amtsenthebung und Weggang aus Göttingen und leitete Gauß' magnetische Schaffensperiode ein. Die Aktion König Ernst Augusts gegen die Göttinger Sieben im Jahre 1837 traf neben Weber auch Gauß' Schwiegersohn Georg Heinrich Ewald, der 1830 Gauß' Lieblingstochter Wilhelmine (,Minna“) geheiratet hatte. Ewald wurde umgehend nach Tübingen, Weber später nach Leipzig berufen. Überraschend starb Wilhelmine in Tübingen bereits 1840 und im gleichen Jahr verschied mit Wilhelm Olbers sein väterlicher Freund und spiritus rector der frühen Jahre, zwei Ereignisse, die im 63-jährigen Gauß ein Gefühl der Einsamkeit erzeugt haben. 1850 starb auch sein Freund und Kollege Schumacher in Hamburg. An Bolyai schrieb er bereits einige Jahre vorher: „Es ist der Fluch des Altwerdens, dass man diejenigen die uns von Jugend her teuer waren, Einen nach dem Anderen abtreten sieht, und selbst fast einsam zurückbleibt" ${ }^{\text {"68 }}$. Gauß starb friedlich am 23. Februar $1855^{9}$.

\section{Vorlesungstätigkeit}

Gauß hat zeitlebens ungern Vorlesungen gehalten, da sie seine Gedanken von den wissenschaftlichen Problemen ablenkten, in die er sich gerade tief versenkte. Er ist seiner Lehrpflicht aber stets nachgekommen und die guten Studenten waren von ihm fasziniert. Seine von einer kleinen Anzahl von Studenten besuchten Veranstaltungen fanden vermutlich in dem als „Studierstube“ mit a bezeichneten Raum in Abb. 28 und 29 statt $^{10}$.

\footnotetext{
7 Nach A. Galle, Über die geodätischen Arbeiten von Gauß, Gauß Werke, Bd. 11.2, S. 135.

${ }^{8}$ Horst Michling, a.a.O., S. 129.

${ }^{9}$ Sein Sterbezimmer ist der als „Besuchszimmer“

gekennzeichnete Raum c in Abb. 29.

${ }^{10}$ Die tatsächliche und heute noch gültige Raumaufteilung weicht hier von Borhecks Plan in Abb. 29 ab, indem Raum a durch die Verlegung des Treppenhauses auf Kosten der Gesindestube h vergrößert und wie die in der Abbildung darüber angeordneten Räume b und c geteilt und mit einem Vorzimmer versehen wurde. Nach Dr. A. Wittmann (Universitäts-Sternwarte und Gaußgesellschaft) war Gauß' Studierzimmer, in dem sein Stehpult stand, der als Kammer bezeichnete Raum b in Abb. 29.
}

Richard Dedekind, der als 20-jähriger Student eine Vorlesung bei Gauß hörte, beschrieb die Faszination, die der damals schon 73-jährige Gauß auf ihn ausübte ${ }^{11}:$,... Er sprach ganz frei, sebr deutlich, einfach und schlicht; wenn er aber einen neuen Gesichtspunkt hervorbeben wollte, wobei er ein besonders charakteristisches Wort gebrauchte, so erbob er plötzlich den Kopf, wandte sich qu seinem Nacbbarn'2 und blickte ibn während der nacbdrücklichen Rede ernst mit seinen schönen, durchdringenden blauen Augen an. Das war unvergesslich."

\section{Wissenschaftliche Arbeiten mit Bezug zur Sternwarte}

Gauß' überragende Bedeutung als Mathematiker ist unumstritten. Seine mathematischen Arbeiten entstammen sowohl der Braunschweiger als auch der Göttinger Zeit. Einige Arbeiten zur nichteuklidischen Geometrie und zu elliptischen Funktionen entstanden in Göttingen und wurden erst mit dem Nachlass der Öffentlichkeit zugänglich. Die rein mathematischen Arbeiten sollen hier nicht betrachtet werden.

Gauß' Arbeiten auf anderen Gebieten sind nicht weniger bedeutend. Obgleich sein Interesse zunächst der Mathematik galt, bereitete sich Gauß ab 1802 durch messtechnische Übungen systematisch auf die Übernahme einer Sternwarte vor. Diese Entscheidung fiel einerseits aus der Befürchtung, als reiner Mathematiker in Deutschland (im Gegensatz etwa zu Frankreich) keine Anstellung zu finden ${ }^{13}$. Andererseits entsprach seine Hinwendung zur Astronomie und Physik auch seinen Neigungen, wie viele seiner brieflichen Dispute mit Kollegen über die Relevanz und Genauigkeit einzelner Messergebnisse zeigen. Gauß' Wirken lässt sich am besten als das eines umfassend tätigen mathematisch motivierten Wissenschaftlers beschreiben.

\section{Astronomie}

In Göttingen waren die Beobachtungsmöglichkeiten vor Fertigstellung der neuen Sternwarte an

\footnotetext{
11 Zitiert nach Horst Michling, a.a.O., S. 124.

12 D.h. dem ihm zunächst in dem sehr kleinen Vortragsraum sitzenden Studenten.

${ }^{13}$ Lagrange und Laplace erhielten die sehr hohen Gehälter von fast 8000 Rtlr. pro Jahr, während Gauß in Braunschweig nur 600 Rtlr. plus Logis erhielt. In Göttingen wurden ihm zunächst 1000 Rtlr. geboten, Ende 1824 wurde sein Gehalt auf 2500 Rtlr. erhöht. Auch der 1795 als Student erwogene Gedanke, Philologie zu studieren, war vermutlich in Hinblick auf eine spätere Versorgung gefasst (nach M. Brendel, a.a.O.).
} 
der Geismarlandstraße recht beschränkt. Die erste Periode in Göttingen war daher von Arbeiten in Anschluss an seine Bahnberechnung des Planetoiden Ceres (1801) bestimmt. Die exakte Beschreibung der Bewegung kleinerer Massen im Sonnensystem ist ein hochgradig komplexes Problem. Gauß bestimmte eine Näherungslösung für die Bahn der Ceres unter Anwendung der von ihm schon 1794 entwickelten Methode der kleinsten Quadrate, bei der die Bahnparameter optimal an Beobachtungsdaten angepasst werden konnten. Mit dieser Publikation wurde Gauß schlagartig berühmt. Es folgte bis 1805 die Untersuchung der Bahnstörungen der Ceres und der Pallas durch die großen Planeten, die in seine umfassende, zunächst auf Deutsch verfasste „Theorie der Bewegung der Himmelskörper“ mündete, die 1809 in lateinischer Sprache als „Theoria motus corporum coelestium etc.“" publiziert wurde. In Göttingen widmete sich Gauß Rechnungen zur Störungstheorie vor allem am Beispiel der Pallas, die einen immensen Umfang annahmen ${ }^{14}$. Mit mehreren veröffentlichten Arbeiten legte er die Grundlagen für die in späteren Jahren sehr erfolgreiche Störungstheorie der Planetenbahnen. Mit einer allgemeinen Störungstheorie wollte sich Gauß um den prestigeträchtigen, 1804 von der Pariser Académie des Sciences für eine solche Theorie ausgesetzten Preis bewerben und Olbers, der Urheber dieses Preisausschreibens, erreichte auf Gauß' Bitte hin sogar eine mehrjährige Verschiebung des Abgabetermins, aber das Vorhaben erwies sich als zu umfangreich und einen Abschluss hatte Gauß beim Bezug der neuen Sternwarte nicht erreicht. Die nun anstehenden Reisen und Beratungen für umfangreiche instrumentelle Beschaffungen bei Reichenbach, Fraunhofer, Utzschneider u.a. lieBen ihm für derart aufwendige numerische Rechnungen nicht mehr die erforderliche Muße und Konzentration. Viele Jahre später sah er sich nicht mehr in der Lage, den Zahlenwust zu ordnen: Am 21. März 1843 schreibt er an Bessel in Königsberg „...(dies) bat in mir eine Erinnerung geweckt, die mir immer schmerz̧baft ist, nämlich an meine alte Arbeit über die Pallasstörungen. Sie ist seit fast einem Vierteljabrbundert mir so fremd geworden, dass es mir schwer wird, mich selbst in den vorbandenen Papieren zu orientieren ...". Moderne numerische Rechnungen erfolgen nach dem gleichen Schema, das

${ }^{14}$ Diese Rechnungen umfassen etwa 800000 Ziffern, wobei Gauß täglich etwa 3500 Ziffern berechnen konnte.
Gauß anwandte, aber die vielen hundert höheren Terme in den Störungen berücksichtigt der Computer in Sekundenschnelle.

Die erste im Beobachtungsbuch der neuen Sternwarte eingetragene Notiz von Gauß' Hand datiert vom 13. Oktober 1816. Diese Bücher belegen, dass Gauß anstrebte, grundsätzliche Beobachtungen vollständig und mit großer Sorgfalt zu erledigen. Die ersten Messprogramme betrafen z.B. die Schiefe der Ekliptik und die Polhöhe des Standorts der Sternwarte, letztere auf den Bruchteil einer Bogensekunde genau. Messungen dieser Genauigkeit sind erforderlich, um z.B. Eigenbewegungen und Entfernungen (Parallaxen) von Fixsternen zu messen ${ }^{15}$. Diese hohe Genauigkeit wurde vor allem mit dem exzellenten im Oktober 1819 aufgestellten Reichenbachschen Meridiankreis erzielt. Nach Beginn der Hannoverschen Landesvermessung 1820 traten rein astronomische Beobachtungen stark zurück. Die Freude am Beobachten richtete sich zunächst auf die Landesvermessung, später auf den Magnetismus und erst im Alter wieder auf die Astronomie. 1846 kehrte Gauß noch einmal zu systematischen Untersuchungen früher beobachteter Fundamentalsterne zurück und beobachtete Planeten, darunter Neptun. Eine Untersuchung der Sonnenfinsternis vom 28. August 1851 ist wohl seine letzte systematische Beobachtung gewesen.

\section{Geodäsie}

Die Landesvermessung gehörte um 1800 zu den allgemeinen Aufgaben der Sternwarten. Gauß befasste sich bereits 1796 und 1798 mit mathematischen Problemen der Vermessung und gewann ab 1802 durch Vermittlung von Zach auf der Seeberger Sternwarte bei Gotha praktische Erfahrung. In Göttingen machte er als erstes eine Azimutbestimmung, seiner Neigung folgend, grundlegende Messverfahren systematisch auszuprobieren ${ }^{16}$. Im Winter 1808/9 studierte Heinrich Christian Schumacher bei ihm, der später die dänische Landesvermessung durchführte. Als Professor in Kopenhagen lud Schumacher Gauß in einem Brief vom 8. Juni 1816 ein, diese Vermessung vom dänischen Altona (heute Teil von

\footnotetext{
15 Die Messung der ersten Fixsternparallaxe gelang Bessel im Jahre 1838.

16 “... Vom Mittelpunkt der Sternwarte gesehen ist das Azimuth von Clausberg 220 $24^{\prime} 50^{\prime \prime}$. Die direkte Auflösung des Problems beruht auf 3 sphärischen Dreiecken ...”. Brief von Gauß an Olbers, a.a.O., Nr. 207, Nov. 1807. Gemeint ist hier eine Marke auf dem Klausberg im NO des heutigen Göttinger Stadtgebiets, $3 \mathrm{~km}$ von der Sternwarte entfernt.
} 
Hamburg) aus nach Süden fortzusetzen - ein Unterfangen, dessen Finanzierung 1820 von König Georg IV. bewilligt wurde. Die mit Hilfe von Militärpersonal durchgeführte Hannoversche Landesvermessung hat $\mathrm{Gau}$ mit aller verfügbaren Zeit bis 1825 beschäftigt. Hierzu gehörten neben der umfangreichen Logistik und vielen beschwerlichen Reisen zur Erkundung geeigneter Messpunkte und zur späteren Durchführung der Messungen auch der Kauf und die Entwicklung des dafür erforderlichen Instrumentariums. Eines der wesentlichen Hilfsmittel für die eigentliche Vermessung war der von Gauß erfundene Heliotrop ${ }^{17}$, der es gestattete einen von der Sonne beschienenen entfernten Messpunkt anzupeilen.
Gauß hatte die Anregung dazu erhalten, als er den Turm von St. Michaelis in Hamburg von Lüneburg aus anpeilte und ihn ein die Sonne spiegelndes Fenster des Turms störte. Nullpunkt dieser Landesvermessung war die Position des Reichenbachschen Meridiankreises in der Göttinger Sternwarte ${ }^{18}$. Zur genauen Nord-SüdAusrichtung des Meridiankreises ließ Gauß nach längeren Verhandlungen zwei von der Sternwarte aus anpeilbare Meridianzeichen im Norden und Süden in 5 bzw. $12 \mathrm{~km}$ Entfernung errichten. Im Osten konnte Gauß einen Anschluss an die preußische, im Süden an die hessische und nach Westen an die niederländische Vermessung sicherstellen. Ein Problem stellte der Mangel an weithin sichtba-

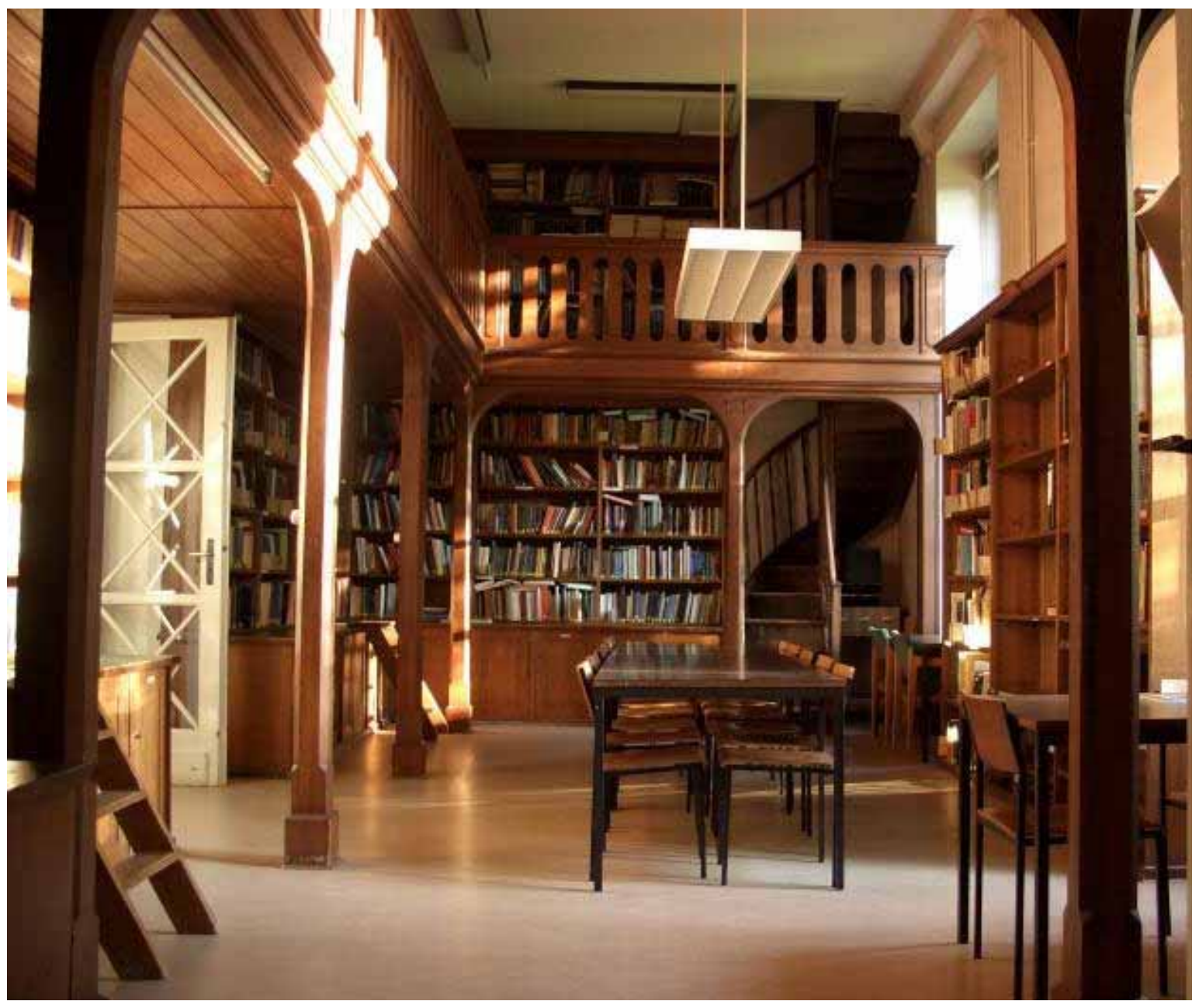

Abb. 13 Der westliche Vorbereitungsraum L in Abb. 26. Dieser Raum war ursprünglich Vorbereitungsraum für astronomische Beobachtungen und wurde ab 1831 von Gauß für Messungen zum Magnetismus benutzt. Die Galerie mit Zugang über die Wendeltreppe stammen aus dem Umbau 1887/88 (s. auch den Beitrag von R. Förster). Seit ca.1930 ist hier die Bibliothek der Sternwarte untergebracht (Foto K. Reinsch, Universitäts-Sternwarte).

17 Ein überkommenes Exemplar war auf der 10 DM Banknote abgebildet und ist in der historischen Sammlung des I. Physikalischen Instituts der Fakultät für Physik der Universität Göttingen erhalten.

18 Die Markierung dieses Nullpunktes ist heute noch in der Sternwarte zu besichtigen. 


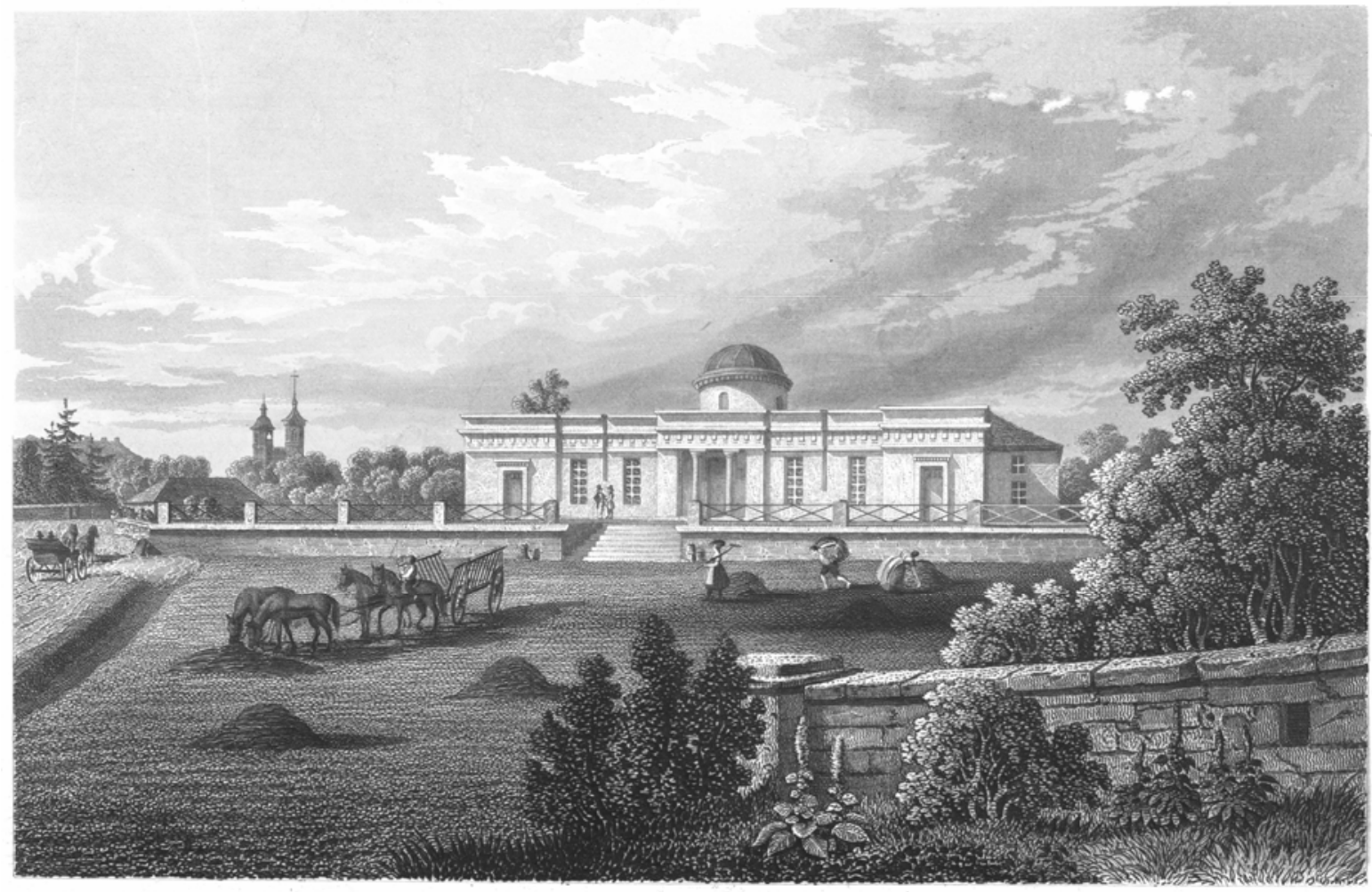

Abb. 14 Die Sternwarte in Göttingen, gezeichnet von Friedrich Adolf Hornemann, in Stahl gestochen von E. Wagner, gedruckt bei G. Lange in Darmstadt. Links sieht man die Türme der Johanniskirche und das Dach des magnetischen Observatoriums. Das Bild ist der Schrift über die 31. Versammlung Deutscher Naturforscher und Ärzte 1854 beigefügt und dürfte mit Gauß’ Billigung aufgenommen worden sein (Besitzer K. Beuermann).

ren Erhebungen in der Lüneburger Heide dar, der z.T. nur durch das Hauen von Schneisen durch den Wald behoben werden konnte. Die Strapazen dieser mehrjährigen Unternehmung werden in Gauß' Briefen anschaulich geschildert. Nach Abschluss der Arbeiten nahm Gauß Urlaub, um seine damals schon kranke Frau Minna zu einem Kuraufenthalt zu begleiten.

Eine Fortsetzung der Vermessung auf das gesamte Königreich Hannover fand ab 1828 unter Gauß' Leitung aber jetzt durch Mitarbeiter und durch Gauß' Sohn Joseph statt. Teile der Daten hat Gauß jedoch bis 1838 selbst analysiert. Wissenschaftliche Früchte der Vermessungsarbeit waren - zumindest im Grundsatz - eine Gradmessung, d.h. eine Messung des Erdradius und grundlegende Informationen zur Gestalt der von einer Kugel abweichenden Form der Erde. Theoretische Arbeiten von Gauß zu diesen Themen haben die Geodäsie und die Mathematik nachhaltig befruchtet. Hierzu gehören die Theorie der konformen Abbildungen und die Flächentheorie.

\section{Magnetismus und Elektrodynamik}

Gauß hat sich früh mit Fragen des Magnetismus befasst ${ }^{19}$, ist allerdings erst 1831 durch Weber zu nachhaltigen und grundlegenden Versuchen angeregt worden. Auch Begegnungen und die Korrespondenz mit Alexander von Humboldt ${ }^{20}$ haben dazu beigetragen, dass sich Gauß physikalischen Fragestellungen zuwandte. Aus Gauß' Briefen geht jedoch hervor, dass er sich bereits 1806 mit Fragen des Erdmagnetismus befasste und die Idee einer Entwicklung nach Kugelfunktionen schon im Anfang seiner Göttinger Zeit formuliert hatte ${ }^{21}$. Für diese Arbeiten wurde in der Sternwarte der neben dem westlichen Meridianraum liegende Raum $\mathrm{L}$ (Abb. 28, heute Bibliothek) für magnetische Experimente eingerichtet. Um dem störenden Einfluss von Eisenteilen im Baukörper zu entgehen, ließ er im Jahre 1833 im Garten der Sternwarte ein eisenfreies, als magnetisches Observatorium bezeichnetes Holzhaus

\footnotetext{
19 Briefe an Olbers aus den Jahren 1803, 1812, 1820, 1829.

${ }^{20}$ Gauß stand spätestens ab 1807 mit Alexander von Humboldt in Kontakt. Wilhelm von Humboldt versuchte 1810 ihn nach Berlin zu berufen. Dieser Versuch wurde 1821-25 noch einmal wiederholt.

${ }^{21}$ Briefe an Harding (1806), Encke (1839) und Schumacher (1842); nach Cl. Schaefer, Gauß Werke, Bd. 11.2, S. 93.
} 
errichten $^{22}$. Auf dem Lageplan der Sternwarte (Abb. 8 und 19) ist es ganz links im spitzen Winkel des Sternwartengrundstücks dargestellt und ist auch auf dem Hornemannschen Stich zu erkennen (Abb. 14). Die Beobachtungen in diesem Gebäude dienten vor allem Untersuchungen des Erdmagnetfeldes und seiner zeitlichen Veränderungen $^{23}$. Der Erfolg dieser Messungen führte zur Gründung des Magnetischen Vereins und zu erdumspannenden terminlich festgelegten Messungen des Erdfeldes. Bei der Gründung dieses Vereins spielte Alexander von Humboldt eine maßgebliche Rolle. Besonders wichtig war auch die Einbeziehung der Royal Society, die 1839 zustimmte in zahlreichen britischen Kolonien Messstationen zu errichten. Der Schwerpunkt der weltweiten magnetischen Forschung lag nun in Göttingen. Wesentliche Beiträge von Gauß zu diesem Wissensfeld sind die Absolutmessung der magnetischen Feldintensität (Flussdichte oder Induktion), deren Einheit heute den Namen Gauß trägt, seine „Allgemeinen Lehrsätze“, die allgemeine Theorie des Erdmagnetismus und die Untersuchungen zur Potentialtheorie. Auch Gauß' Untersuchungen zum Elektromagnetismus und das heute allen Studierenden geläufige Gaußsche Maßsystem gehen auf Arbeiten in der Sternwarte zurück. Schließlich wurde 1833 von Gauß und Weber der Telegraph entwickelt, wie die Tafel an der linken Seite der Fassade der Sternwarte verkündet. Diese Erfindung wurde später von Siemens und Halske genutzt und verbreitet.

\section{Optik}

Als Astronom kam Gauß zwangsläufig durch die Unvollkommenheit der damaligen Fernrohre zu optischen Arbeiten ${ }^{24}$. Schon um kompetent in Verhandlungen mit den Herstellern optischer In strumente wie Repsold, Reichenbach, Fraunhofer, Utzschneider treten zu können, war ein detailliertes Verständnis der Entstehung optischer Abbildungen erforderlich. Repsold in Hamburg z.B. erbat mehrfach genaue Angaben über die Eigenschaften der zu schleifenden achromatischen Linsen, die Gauß ihm auch lieferte. Nach der Methode von Gauß berechnete Objektive und Okulare wurden später mit großem Erfolg hergestellt ${ }^{25}$. Auch auf Mikroskope wurde seine Methode mit Erfolg angewandt. Unter den verschiedenen Publikationen auf dem Gebiet der Optik sind besonders seine „Dioptrischen Untersuchungen“ über die Bildentstehung in zentrierten Systemen brechender Kugelflächen hervorzuheben, die 1840 erschienen. Vorarbeiten dazu entstanden aber nachweislich schon in den Anfängen seine Göttinger Zeit oder sogar davor.

Gauß' gesammelte Werke auf den Gebieten der Mathematik, Astronomie und Physik wurden von der ehem. Königlichen Gesellschaft für Wissenschaften zu Göttingen in 12 Bänden in den Jahren 1863-1929 herausgegeben. Sie sind die Hinterlassenschaft eines genialen Wissenschaftlers aus 48 Jahren fruchtbarer Arbeit an der Sternwarte der Universität Göttingen.
22 Dieses wurde später auf das Gelände des Instituts für Geophysik auf dem Hainberg umgesetzt und soll im Rahmen der Restaurierung der Sternwarte an seinen ursprünglichen Standort zurückgeführt werden.

23 An den Messungen in Göttingen nahmen außer Gauß und Weber noch 7 Hilfskräfte und Gauß' Sohn Wilhelm teil.
${ }^{24}$ Die Inventarverzeichnisse der Sternwarte aus dem 18. und 19. Jahrhundert verzeichnen mehrere Teleskope und Spektrografen, auch namhafter Hersteller, die in den Kommentaren schlichtweg als unbrauchbar eingestuft werden.

${ }^{25}$ Steinheil berichtet 1860 über ein nach Gauß berechnetes Fernrohrobjektiv u.a.: „Der erste Blick durch das Fernrohr wird jedem Kenner sagen, dass es von ungewöhnlicher Schärfe und Farblosigkeit ist." 


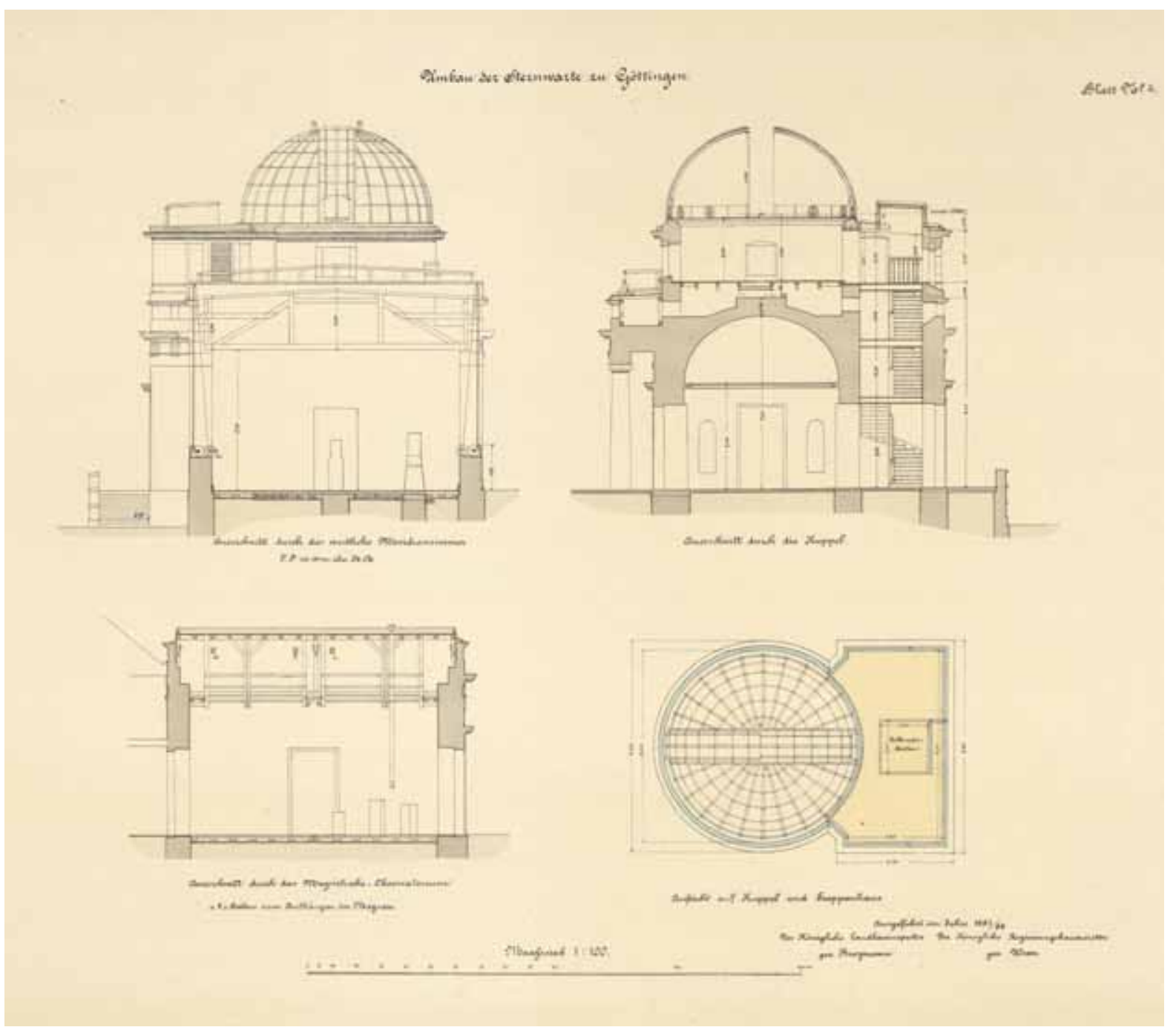

Abb. 11: Querschnitt durch das Hauptgebäude der Sternwarte für den Umbau 1887/88 


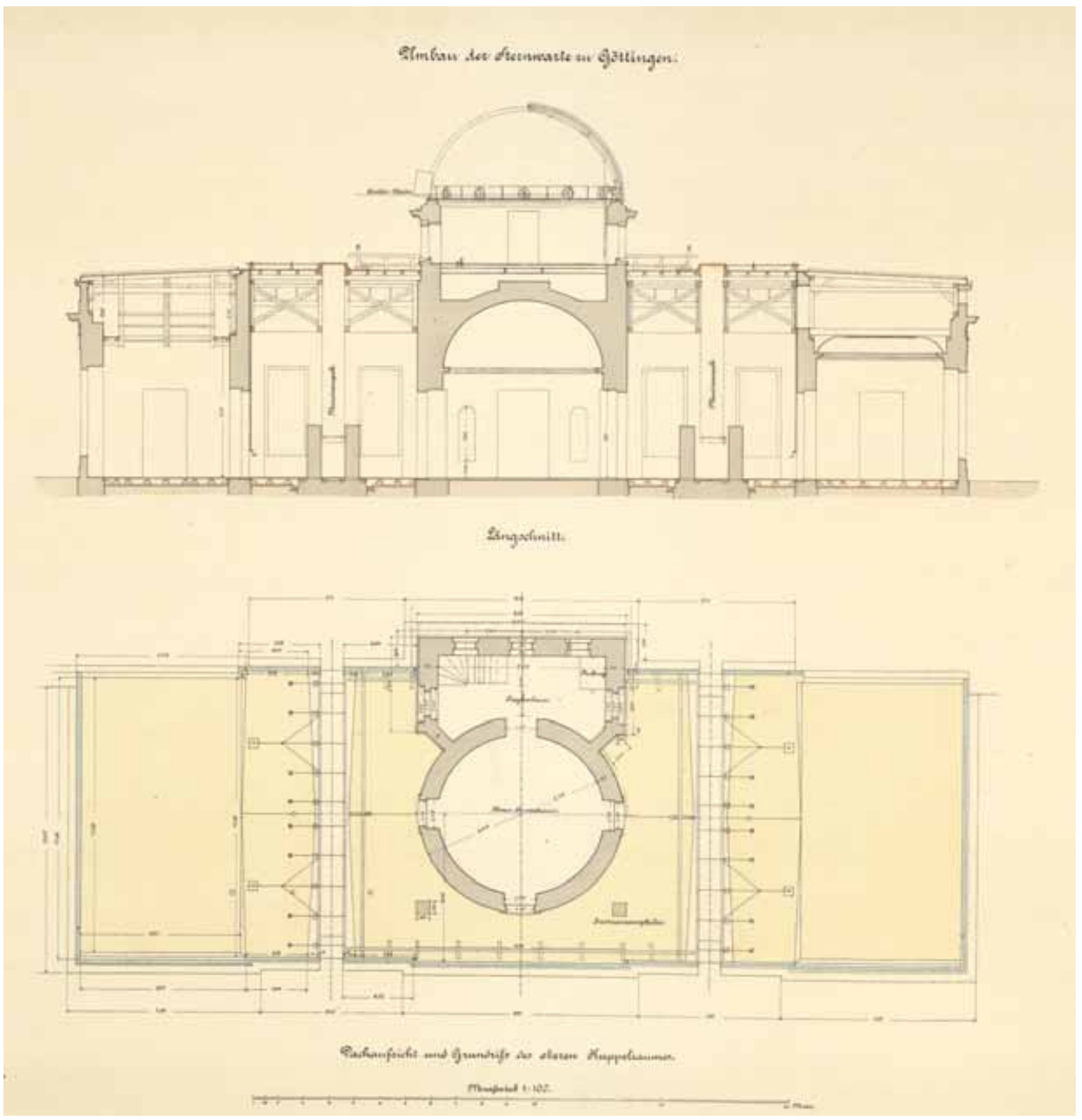

Abb. 12:Längsschnitt und Dachaufsicht des Hauptgebäudes der Sternwarte für den Umbau 1887/88. Hier sind vor allem die breiteren Meridianspalte und die Fundamente der Meridiankreise zu sehen. Weitere Details sind im Beitrag von Robert Förster beschrieben. 


\section{Die Sternwarte zu Göttingen im Wandel der Zeiten - Umbauten und Restaurierungen}

\author{
von Robert Förster, Göttingen
}

Die vor den Toren der Stadt Göttingen zwischen 1803 und 1816 erbaute Sternwarte in Form einer Dreiflügel-Anlage setzte sich aus dem Institutsgebäude und zwei Wohntrakten zusammen. Der Direktor der Sternwarte Carl Friedrich Gauß bezog den westlichen Flügel, sein Kollege KarlLudwig Harding den östlichen Flügel. Die Freiflächen um das Gebäude wurden im Westen als Wandelgarten mit entsprechendem Wegenetz und im Osten als Nutzgarten angelegt. Das Gebäude wurde von Süden erschlossen durch eine Zufahrt, die im Oval vor der Haupttreppe angelegt war. Der Zugang für Gesinde und Anlieferungen erfolgte über einen mit Muschelkalk gepflasterten Weg auf der Nordseite, der zum Innenhof führte. Dieser wurde als Wirtschaftshof mit Brunnen und Abfalldeponie genutzt. Da die Sicht aus den Meridianspalten nicht verstellt werden durfte, bestand ein Bebauungsverbot für die Flächen rund um das Gelände der Sternwarte.

Schon Gauß war mit den Nutzungsmöglichkeiten der Sternwarte alles andere als zufrieden. ${ }^{1}$ Die obere Kuppel ließ sich kaum öffnen und wies nur kleine Klappen auf, die einzeln geöffnet werden mussten und nur eine kurze Beobachtungszeit der einzelnen Sterne erlaubte. Zudem bot sie keine Möglichkeit für die Aufstellung größerer Instrumente. Auch die Meridianzimmer wiesen Mängel auf, da die Spalte zu eng angelegt waren. Der westliche Vorbereitungsraum wurde

\footnotetext{
1 Hierzu und zum folgenden: Wever, Umbau der Sternwarte zu Göttingen. In: Zeitschrift des Architektur- und Ingenieurvereins zu Hannover 2, 1893, Sp. 157-164, Zeichnungen Blatt 6-8. Schriftverkehr zu den Baumaßnahmen an der Sternwarte im Bestand SUB Göttingen, Ms. Cod. Sternwar-
} te, hier bes. Nr. 5-10. von Gauß zum magnetischen Observatorium bestimmt, das aber durch die zahlreichen Eisenteile im Institutsgebäude viele Störfaktoren aufwies. Daher ließ Gauß im Sommer 1833 nach einem Entwurf des Universitätsbaumeisters Prael in der äußersten westlichen Ecke des Grundstücks ein kleines Gebäude - das so genannte ,Gauß-Haus` - als magnetisches Observatorium errichten. ${ }^{2}$ Es hatte zunächst die Form eines einfachen Rechteckbaus mit schlichtem Risalit, in dem der Nachtwächter der Sternwarte untergebracht wurde. In der Zeit bis 1888 wurde das ,Gauß-Haus' zur heutigen T-Form umgebaut und vergrößert. Dieses Gebäude, das 1902 auf das Gelände der Geophysik auf den Hainberg umgesetzt wurde, ${ }^{3}$ besteht aus einer Holz-FachwerkKonstruktion, in der auch die Verbindungsteile wie Nägel und Schrauben aus Messing oder Kupfer gefertigt und damit nicht magnetisch sind.

Die oben erwähnten Mängel der Sternwarte führten zu einem ersten großen Umbau in den Jahren 1887/88, der von dem Professor Ernst Schering seit 1884 zusammen mit dem Landesbauinspektor Kortüm in die Wege geleitet und unter Professor Wilhelm Schur nach dessen Wünschen ausgeführt wurde. Die Oberbauleitung hatte der Bauinspektor Breymann. Begonnen wurde mit dem Abbruch der Dächer über den Beobachtungsräumen. Durch den Umbau wurden die Meridianspalte und die Deckenöffnungen auf $88 \mathrm{~cm}$ Breite erweitert. Die Seitenlinien der Meridianspalte wurden mit senkrechten Rollläden versehen, die sich nach unten aufrollten, um nicht für jede Beobachtung den ganzen Spalt öffnen zu müssen. Im übrigen war es der Wunsch von Professor Schur, möglichst „zugfrei“ arbeiten zu können. ${ }^{4}$ Die Rollläden wurden aus Holz hergestellt, um bei magnetischen Beobachtungen „Einflüsse der senkrechten Eisenmassen“5 auszuschließen. Die Öffnungen im Dach wurden nicht wie bisher mit Klappen geschlossen, die mit entsprechenden Gegengewichten nach oben aufschlugen, sondern mit einfachen waagerechten Schiebeplatten. Es bestand so die Möglichkeit, nur die eine Hälfte des Dachs zu

\footnotetext{
2 Universitätsarchiv Göttingen, Kur 4Vf 48.

3 Vgl. den Brief des Baurats Breymann an den Direktor der Sternwarte Schur vom 27. Februar 1902 (SUB Göttingen, Ms. Cod. Sternwarte Nr. 9), in dem die Umsetzung des ,Gauß-Hauses’ im März 1902 angekündigt wird.

4 Wever (wie Anm. 1), S. 157.

5 Vgl. SUB Göttingen, Ms. Cod. Sternwarte Nr. 9 (Schreiben vom 12. 9. 1887).
} 
öffnen. Die hölzernen Schiebeplatten konnten mit Hilfe von Zahnstangen, Zahnrädern, Wellen und Kurbeln vom Meridiansaal aus bedient werden und wurden quer zu den Meridianspalten verschoben.

Der Raum über dem unteren Gewölbe musste aus statischen Gründen von dem bei der Erbauung eingebrachten Bauschutt befreit werden, da dieser in den tragenden Säulen des Gewölbes Risse verursacht hatte. Ursprünglich sollte dieser Einschub von Masse dazu dienen, die Instrumente möglichst erschütterungsfrei benutzen zu können. Anstelle der alten, kaum drehbaren Kuppel wurde eine neue installiert, die leicht von einer Person gedreht werden konnte. Offensichtlich hatte man bei der Ausschreibung der neuen Kuppel die Bedachung vergessen, so dass die damalige Bauverwaltung nachbessern musste. Es wurde eine Zinkblecheindeckung gewählt, die als Leistendach ausgeführt wurde (Vorläuferkonstruktion zur heutigen Stehfalzdeckung). Die Dichtigkeit dieser Eindeckung wurde besonders lobend erwähnt.

Das magnetische Observatorium wurde zunächst wieder in den westlichen Vorbereitungsraum verlegt, der mit der noch heute vorhandenen Galerie und der ebenfalls noch vorhandenen Wendeltreppe ausgerüstet wurde, um Drähte für kleine herabhängende Magnete durch den Raum spannen zu können - allerdings mit dem Vermerk ,,vorläufig", da man bereits einen Neubau des Observatoriums plante. ${ }^{6}$ In diesem Raum wurde ebenso wie im ,Gauß-Haus' der Einbau von Eisen vermieden, stattdessen verwendete man auch hier Verbindungsteile aus Kupfer oder Messing. Der westliche Vorbereitungsraum wurde später zur Bibliothek umgestaltet.

In den Meridiansälen standen die Pfeiler, die als Fundamente der Instrumente dienten, frei von anderen Bauteilen einen Meter tief im Erdreich, so dass Erschütterungen nicht übertragen werden konnten. Im westlichen Meridiansaal wurden herausnehmbare Fußbodendielen (Fußbodenklappen) eingebaut, unter denen Sandsteinschwellen zur zeitweisen Aufnahme von Quecksilberspiegeln (Messung von reflektierten Sternbildern) lagen. Um einen möglichst schnellen Ausgleich der Temperaturen zwischen der Innentemperatur der Meridiansäle und der Außentemperatur zu erzielen, wurden über den Fenstern dicht unter dem Dach kleine Jalousiefenster angelegt.

Im Wirtschaftshof wurde zum Hauptgebäude eine neue von zwei Seiten begehbare Freitreppe

${ }^{6}$ Wever (wie Anm. 1), S. 160. hergestellt. Die beiden Treppenläufe führen zu einem Podest vor der Eingangstür, das auch als Stellfläche für optische Geräte diente. Diverse heute noch im Sandstein befindliche Markierungen dienten früher zur richtigen Positionierung der Geräte.

Die astronomischen Beobachtungen fanden seit 1933 nicht mehr in der Sternwarte statt. Hierzu diente nun ein Gebäude auf dem Hainberg, das bessere Arbeitsbedingungen bot. Auch ein Sonnenlabor wurde 1944 auf dem Hainberg erstellt. Das Innere der Sternwarte wurde in der Folgezeit für die Bedürfnisse neuer Nutzungen umgebaut. Im Jahr 1926 wurde der östliche Meridiansaal aufgelassen und man baute eine Zwischendecke sowie Trennwände ein, um im Obergeschoss die benötigten Büroräume zu schaffen und im Erdgeschoss den heute noch vorhandenen Hörsaal einzurichten. ${ }^{7}$ Im gleichen Jahr wurden die bis heute erhaltenen Türen mit den groBen Glaseinsätzen an den vier Ausgängen des unteren Kuppelraums eingesetzt. Die Bibliothek wurde vom östlichen Vorbereitungssaal in den westlichen Vorbereitungssaal verlegt und die hölzerne Galerie zu diesem Zweck mit Regalen ausgestattet. Erst im Jahr 1932 ist der westliche Meridiansaal umgebaut worden, zunächst aber nur unter Schaffung von vier Arbeitsräumen im Erdgeschoss mit einer Zwischendecke. Der Einbau einer zweiten Zwischendecke zur Einrichtung von Arbeitsräumen im ersten und zweiten Obergeschoss fand erst 1937 statt. Im Zuge dieser Baumaßnahmen wurden die Meridianspalte geschlossen. Die äußere Gestalt des Gebäudes blieb bis auf die Eingriffe von 1887/88 weiterhin unverändert. Ende des 20. Jahrhunderts wiesen Putz und Sandsteinoberflächen jedoch so große Schäden auf, dass im Jahr 1993 eine Maßnahme zur Fassadensanierung angemeldet werden musste. Die Putzflächen waren hohl und fielen an etlichen Stellen ab, auch der Sandstein zeigte deutliche Auflösungserscheinungen, die schon einige Zentimeter tief in die Oberfläche hineinreichten. Besonders marode waren der Sockel, die Eckquader und die Guttae der Fassade.

Die Fassadensanierung erfolgte nach vorliegenden Befunduntersuchungen und wurde fachgerecht mit Vierungen und Antragungen ausgeführt. Etliche Muster-Sandsteine wurden zur farblichen Klassifizierung und zur Festigkeitsbestimmung vorgelegt.

\footnotetext{
7 Hierzu und zum folgenden SUB Göttingen, Cod. Ms.
} Sternwarte, Nr. 7. 


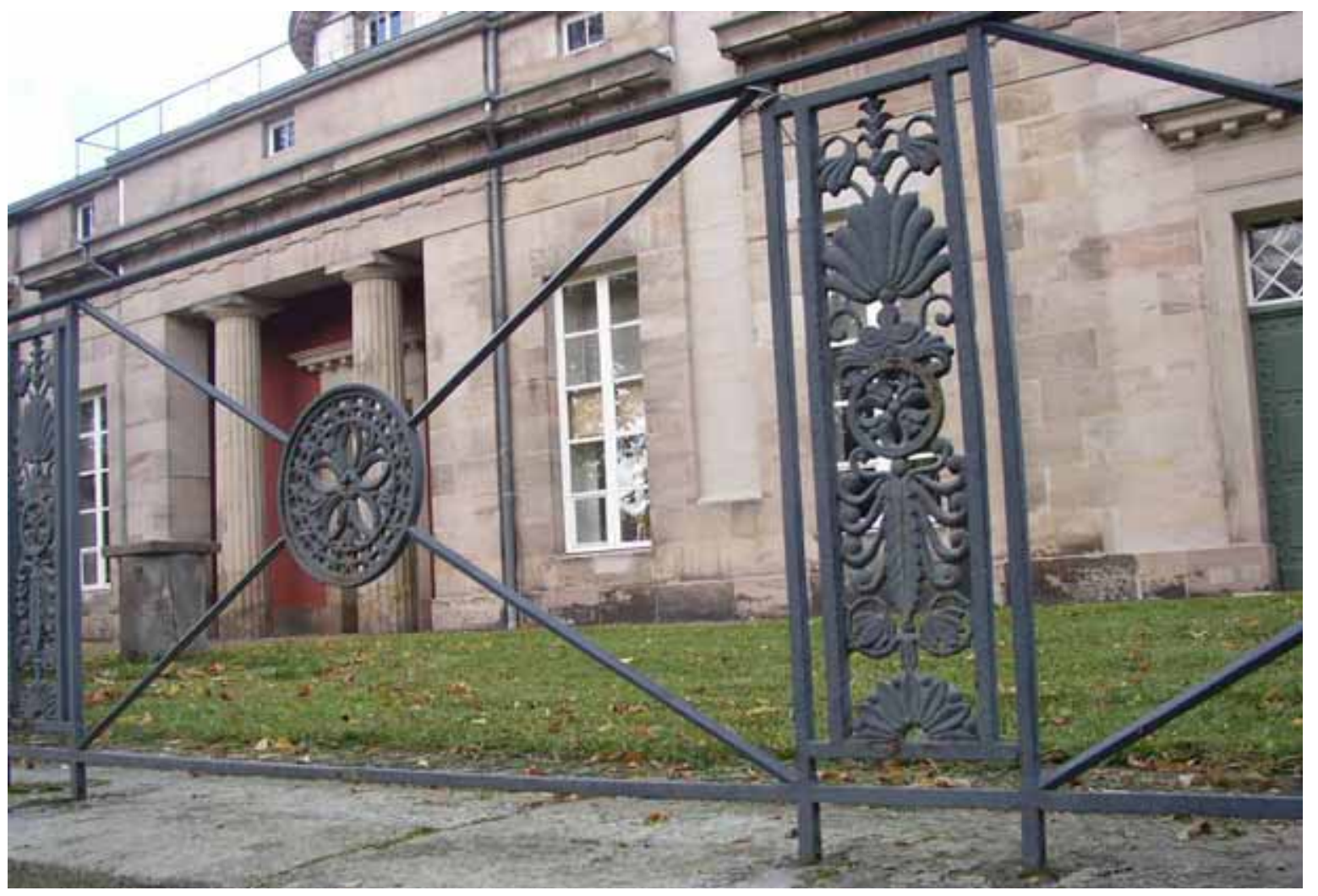

Abb. 17: Das gusseiserne Gitter der Terrassenumzäunung aus dem Jahre 1816 (Photo R. Förster)

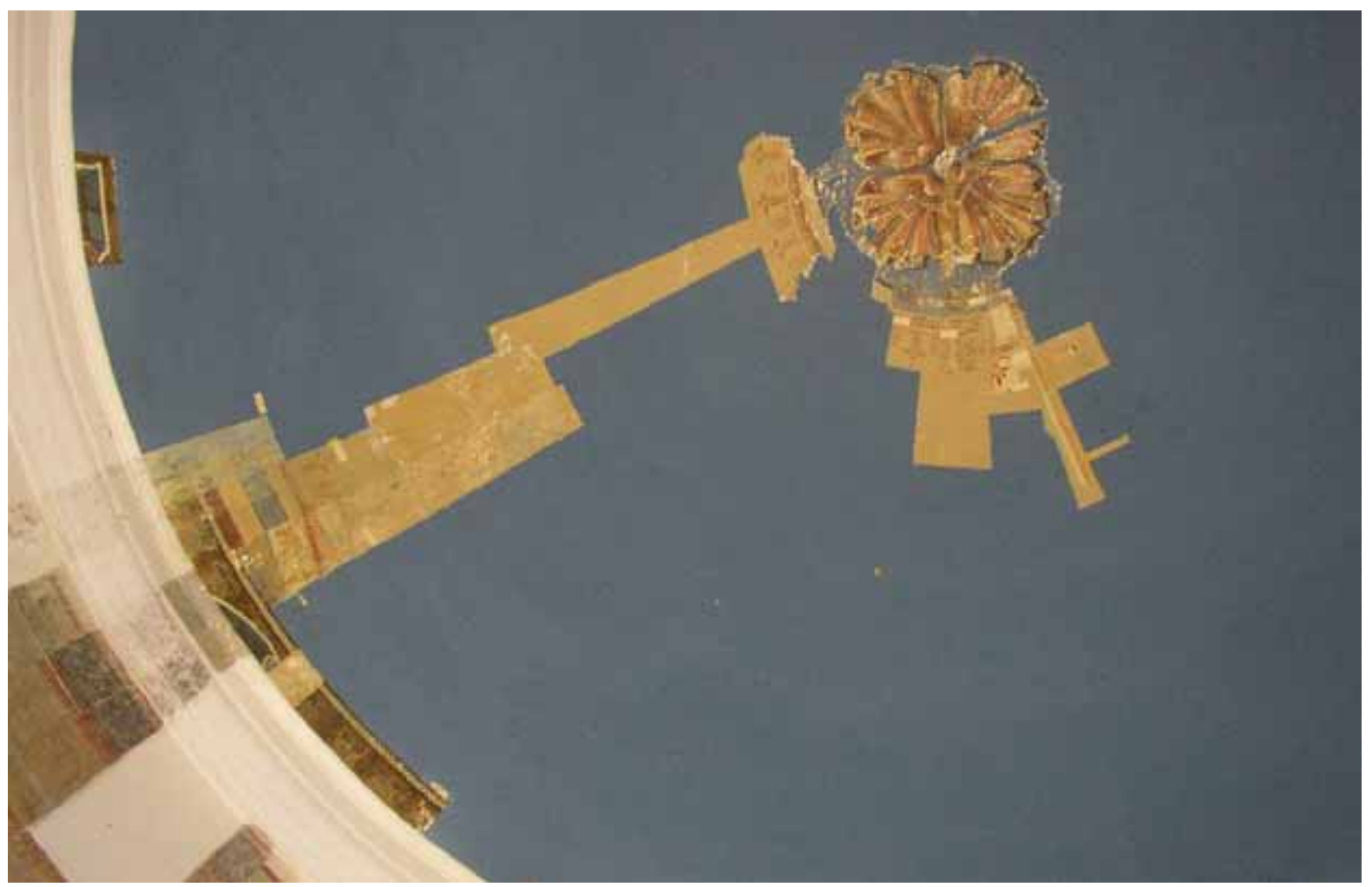

Abb. 18: Freilegung früherer Ausmalungen des Kuppelraumes im Erdgeschoss des Hauptgebäudes (Photo R. Förster). 
Die Guttae oberhalb und unterhalb der Triglyphen mussten zum Teil komplett erneuert werden. Die Befunduntersuchungen sorgten an manchen Bauteilen für Überraschungen, so wurde festgestellt, dass die weißen Fenster in der Erstfassung grün gestrichen waren und dass die großen Institutsfenster wie auch einige Eingangstüren noch aus der Bauzeit stammen und damit zum Originalbestand aus der Zeit von Gauß gehören. Auch das Geländer der Terrasseneinfriedung ist noch ein Originalbauteil aus der Bauzeit von 1803 bis 1816. Bei Freilegungsarbeiten an den Sockelquadern der Südseite des Gebäudes wurde unter der rechten Säule, der den Haupteingang rahmenden Säulen, eine profilierte Sockelplatte in etwa einem Meter Tiefe gefunden. Da die fertig gestellten Kanneluren der Säule bis auf die Sockelplatte herunter führen, könnte dieses auf eine Planungsänderung während der Bauzeit schließen lassen. Dabei hätte man von den ursprünglich vorgesehenen Säulenfüßen und Stufen Abstand genommen, um auch am Haupteingang einen stufenloser Übergang $\mathrm{zu}$ schaffen, der die Möglichkeit bot, schwere Instrumente ins Freie zu schieben. Zum Originalbestand gehört auch ein noch völlig intaktes Entwässerungssystem des Regenwassers als Sandsteingerinne mit Abdeckplatten, das während der Sanierungsarbeiten entdeckt wurde. Es verläuft nur im Bereich der Terrasse bis zur Terrassenmauer, danach floss das Regenwasser über den Muschelkalkweg der Nebeneinfahrt.

Im Anschluss an die Fassadensanierung sollte eine Innensanierung der Sternwarte erfolgen, die aber bis heute aus Kostengründen immer wieder verschoben wurde. Die Vorbereitungen dazu, Farbfindung im unteren Kuppelsaal und Farbfindung im Observatorium wurden aber noch durchgeführt und erbrachten erstaunliche Ergebnisse. Im unteren Kuppelsaal sind noch alle früheren Farbfassungen erhalten. Der Untergrund aus der Bauzeit von 1816 zeigt im Kuppelbereich einen ocker getönten Kalksandputz, auf dem eine Schablonenmalerei mit floraler Ornamentik in Kalk-Kasein-Farben erkennbar ist. An den Wänden unterhalb der Profilstuckleiste beginnt die

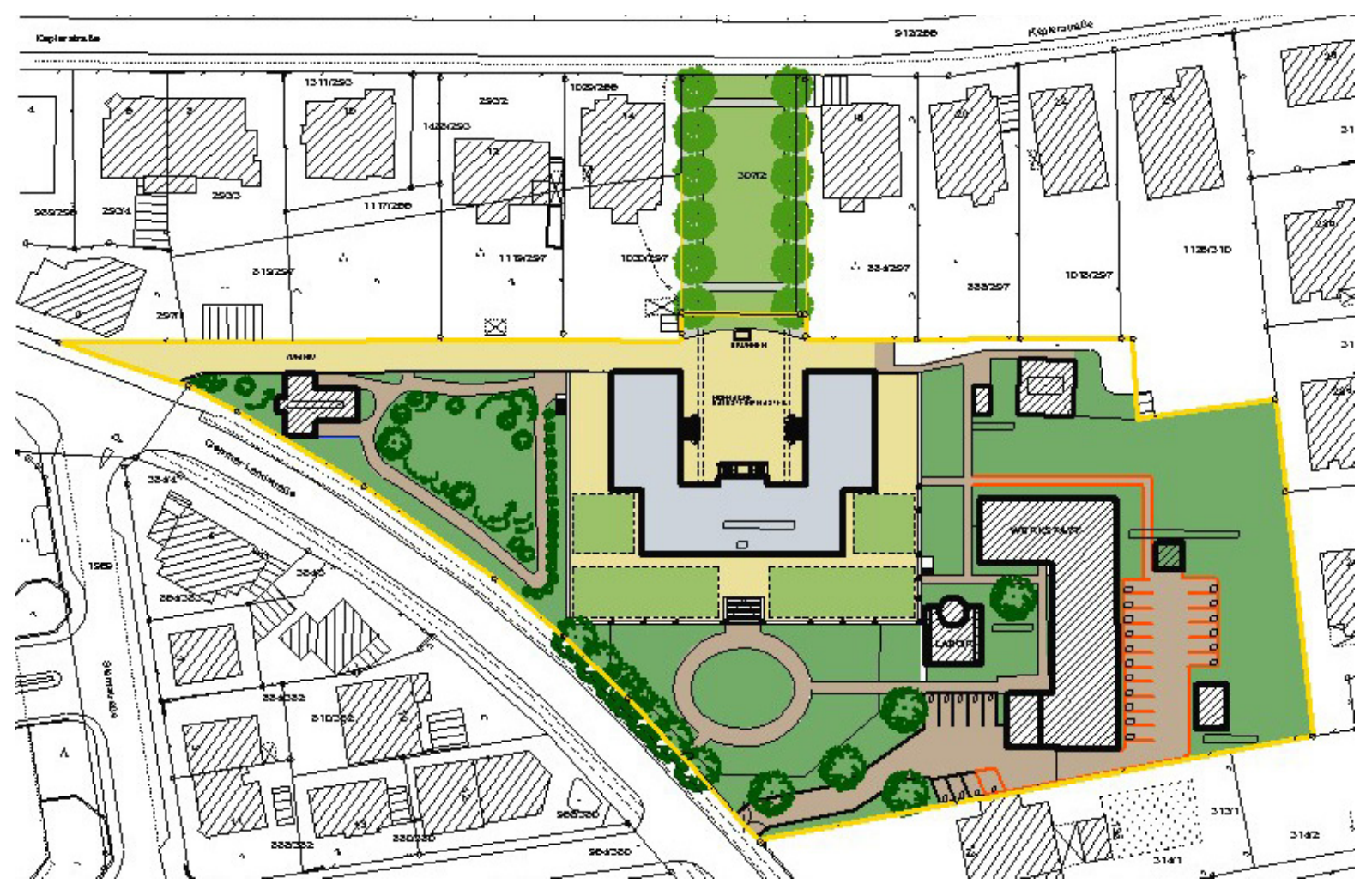

Abb. 19: Lageplan der Universitäts-Sternwarte Göttingen. Schraffiert gezeichnet sind auf dem Sternwartengelände das 1963 errichtete Büro- und Werkstattgebäude, das Gartenlabor, das Hausmeisterhaus mit Garage sowie das hölzerne und eisenfreie magnetische Observatorium, das Gauß 1833 errichten ließ. Dieses „Gaußhaus“ wird im Beitrag von Robert Förster beschrieben und befindet sich heute auf dem Grundstück des Geophysikalischen Instituts auf dem Hainberg. Das unbebaute städtische Grundstück, das nördlich der Sternwarte die Verbindung zur Keplerstraße herstellt, soll parkmäßig gestaltet werden und den Blick auf die Sternwarte freigeben. Im 19. Jahrhundert war eine Bepflanzung und Bebauung nicht zugelassen, um eine Behinderung der Beobachtungen zu vermeiden. 
Erstfassung mit einem mehrfarbigen Fries, darunter in direktem Anschluss zwei rote Bänder. Es schließt sich eine für den Klassizismus typische Kassettenaufteilung an. Die Kassetten sind in zwei Rotstufen angelegt und an den Außenrändern mit schwarzen Linien als Rahmenillusion versehen. Der Schlusssockel ist als Marmorillusion in warmen Brauntönen (Terra di Siena natur) gefasst. Erstaunlich gut ist die dritte Fassung im Kuppelbereich erhalten. Sie zeigt zwischen floralen Elementen zwölf Wappenschilde mit den Symbolen der Sternzeichen in warmen BraunUmbratönen vor rauchig-blauem Hintergrund.

Im Observatorium findet sich in der Kuppel noch ein musterbeschichteter Linoleumbehang aus dem Jahr 1888, der zum einen zur Lichtabsorption diente und zum anderen das Abtropfen des Schwitzwassers von den Eisenteilen verhindern sollte. Der Befund der ehemaligen Meridiansäle zeigt auf rötlichem Kalksandsteinputz eine monochrome umbra-graue Kalk-Kasein-Schicht als erste Fassung. Unter dem Kalksandsteinputz befindet sich ein Natursteinmauerwerk, auf dem Reste eines weißen Kalkputzes zu erkennen sind. Für das Gauß-Jahr 2005 ist die lange erwartete Innensanierung vorgesehen, und dies in einem deutlich größeren Umfang als bisher geplant. Das Institutsgebäude soll in den historischen Zustand zurückversetzt werden. Das bedeutet, dass die völlig verbauten Meridiansäle komplett entkernt und die eingebauten Decken und Trennwände wieder ausgebaut werden. Wandbeschichtung und Fußboden sollen nach Befund wiederhergestellt und der geodätische Nullpunkt - abgedeckt durch eine Glasplatte - für den Betrachter zugänglich gemacht werden. Ebenso soll mit dem ehemaligen östlichen Vorbereitungsraum, der früher teilweise auch als Bibliothek genutzt wurde, verfahren werden. Der westliche Vorbereitungsraum, heute noch als Bibliothek genutzt, verbleibt allerdings in seiner derzeitigen Gestalt. Die eingebauten Bücherregale nebst Umgang und Wendeltreppe stammen noch aus dem 19. Jahrhundert und sollen erhalten werden. Der untere
Kuppelraum erhält gemäß der Farbfindung den Anstrich der Erstfassung. Im Kuppelbereich ist geplant, die Schablonenmalerei mit floraler Ornamentik in Kalk-Kasein-Farben wieder anzubringen, die Wände erhalten unterhalb der Profilstuckleiste den ursprünglichen mehrfarbigen Fries und darunter eine gemalte Kassettenaufteilung im Stil des Klassizismus, die ebenfalls zum Originalbefund gehört. Die darunter liegenden Altfassungen werden fixiert und bleiben somit späteren Generationen erhalten. Das eigentliche Observatorium wird ebenfalls nach Befund restauriert. Hier sind besonders die Linoleumplatten zu restaurieren und zu ergänzen. Die ehemaligen Wohngebäude von Gauß und Harding werden nach Auszug der Astrophysiker einem neuen Nutzer übergeben und erhalten lediglich eine Renovierung.

Die Freiflächen werden, soweit möglich, in die Sanierung bzw. den Rückbau einbezogen. So ist geplant, im westlichen Garten das so genannte ,Gauß-Haus' (Magnetisches Observatorium) vom Hainberg wieder an seinen ursprünglichen Platz zurück zu versetzen und das alte Wegenetz des Gartens wieder anzulegen. Der Weg und der Wirtschaftshof auf der Nordseite sollen vom Asphalt befreit und das Muschelkalkpflaster falls nötig ergänzt werden. Die hier vorhandenen Parkplätze sollen auf die Ostseite hinter das Werkstattgebäude umgesetzt werden. In die historische Gestaltung des Wirtschaftshofes soll das im Besitz der Stadt Göttingen befindliche, immer noch unbebaute Grundstück nördlich vom Wirtschaftshof einbezogen werden. Es soll hier eine visuelle Öffnung der Sternwarte nach Norden mit Bezug auf die Meridianschlitze erfolgen. Die ehemalige Hauptzufahrt im Süden der Anlage, in der durch ein gepflastertes Rondell die alte Umfahrt nachgebildet ist, soll nur überarbeitet werden. Die Wiederherstellung des östlichen Gartens (Obst- und Gemüsegarten) kann heute nicht mehr in die Planung eingebunden werden, da sich hier einige neuere Nebengebäude (Werkstatt, Labor usw.) befinden, die erhalten bleiben und einer Nachnutzung zugeführt werden sollen.

Abb. 20: Faksimile des Titelblatts des Borheckschen Manuskripts von 1805. An den für eine Vignette reservierten Platz hat Borheck nachträglich das kolorierte Stammbuchblatt von Besemann aus dem Jahre 1814 eingeklebt, das den Rohbau der Sternwarte zeigt. 


\section{Sirundrigr}

ilber die

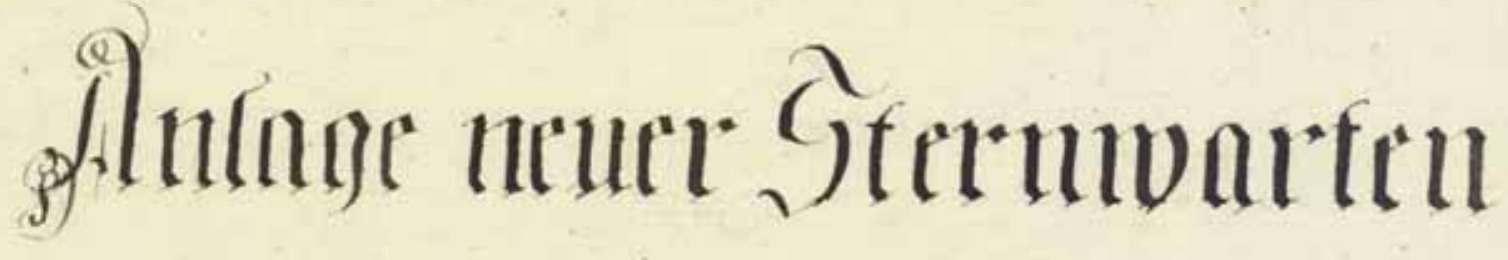

mif ख̉sziebung auf dis

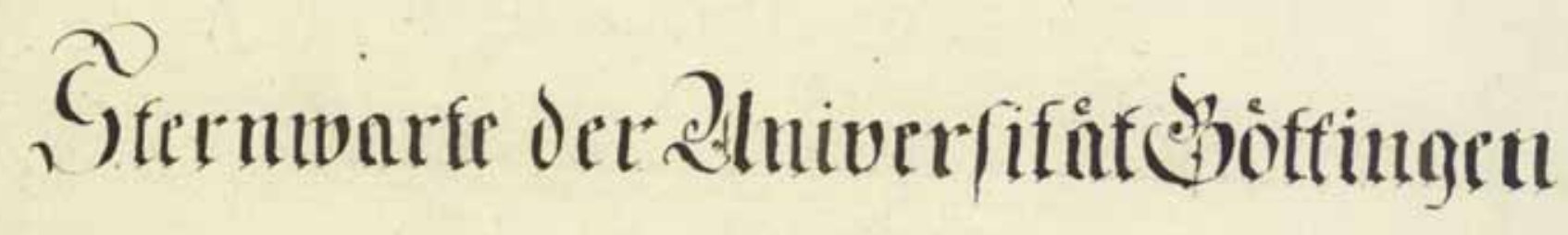
pon

Storg Sucinrith DGorbed

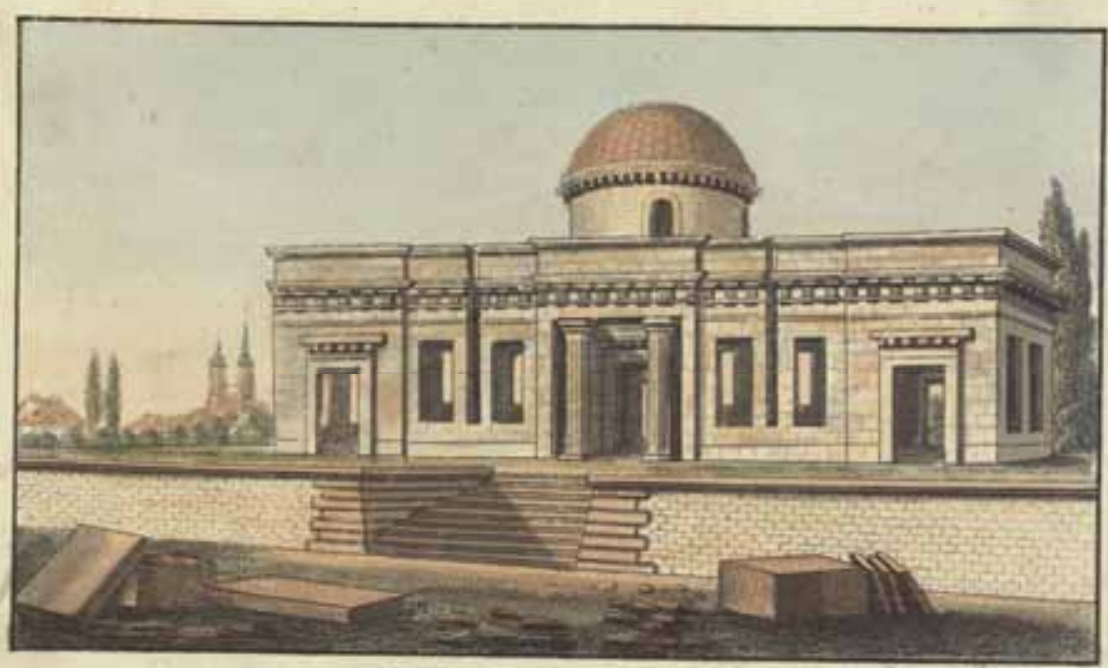

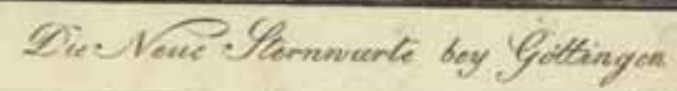

mit vi duprertafeln. is 1805 . 


\section{$\therefore$ orvide}

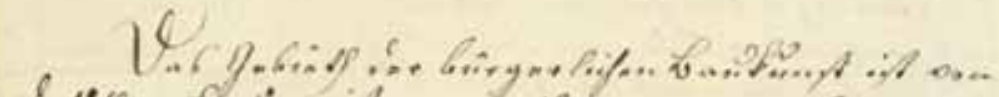

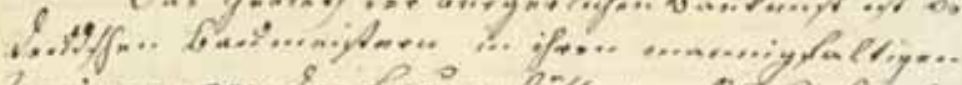

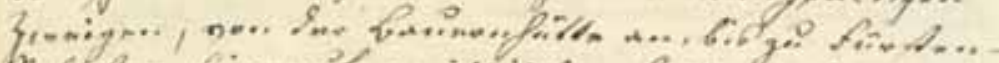
7..

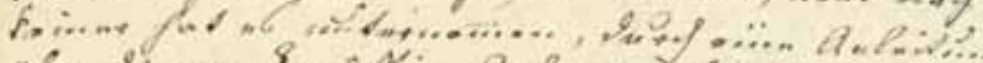

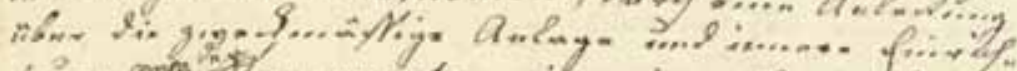

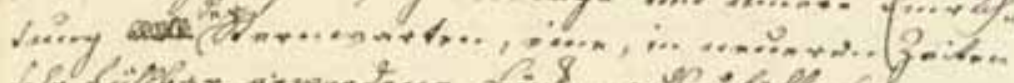

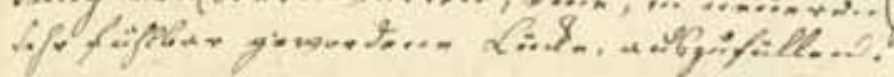

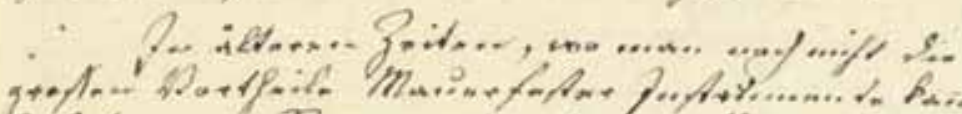

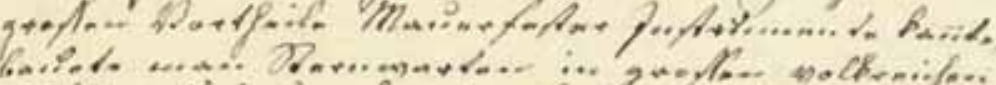
D2.\%. s.

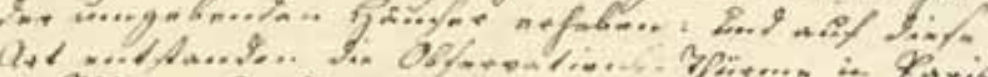
in BDi..., bove..., Ma.... fag.. $z$, 3 .

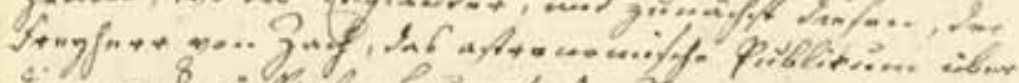
Sin grond ....

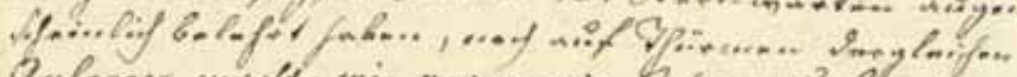

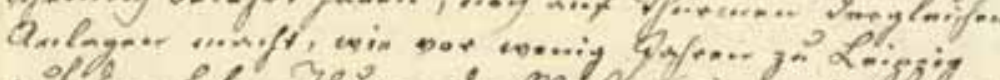

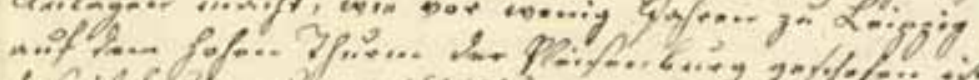

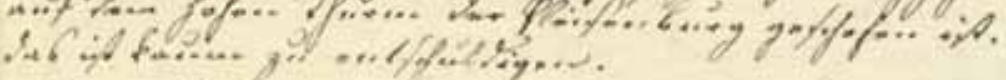

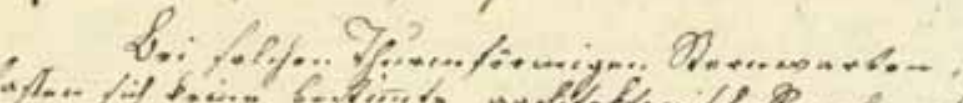

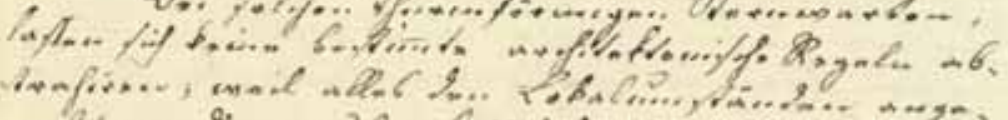

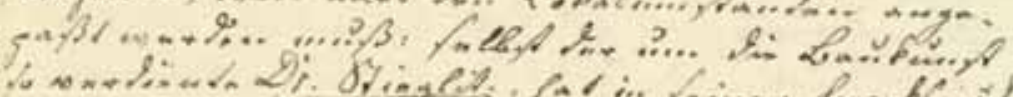

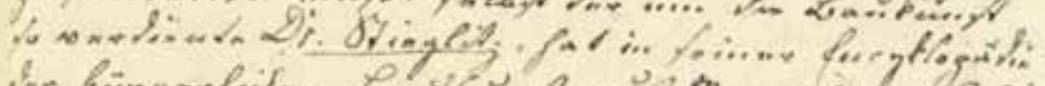

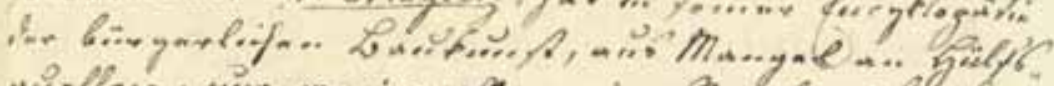

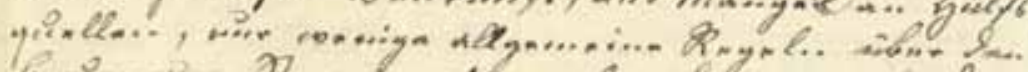

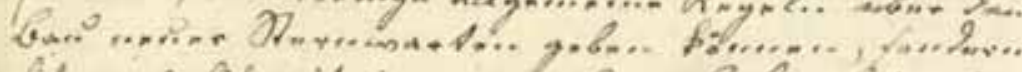

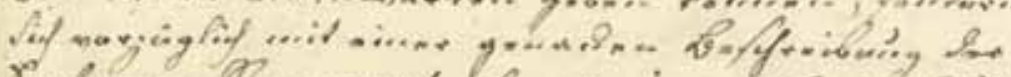

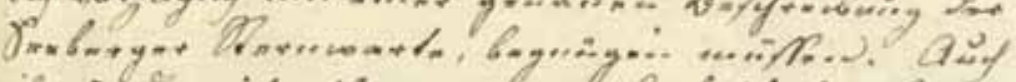

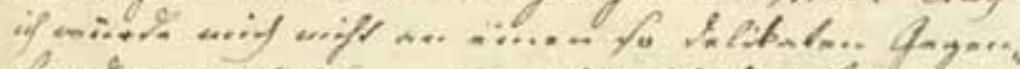

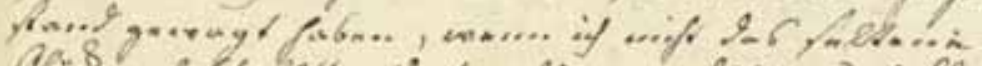

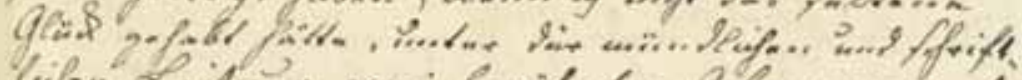

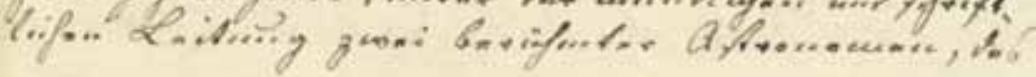

Abb. 21: Faksimile der ersten drei Absätze des 135 Seiten langen Manuskripts von Georg Heinrich Borheck. 


\section{Vorrede}

Das Gebieth der bürgerlichen Baukunst ist von deutschen Baumeistern in ihren mannigfaltigen Zweigen, von der Bauernhütte an, bis zu Fürsten-Palästen hinauf, reichlich bearbeitet, aber noch keiner hat es unternommen, durch eine Anleitung über die zweckmäßige Anlage und innere Einrichtung der Sternwarten, eine, in neueren Zeiten sehr fühlbar gewordene Lücke, auszufüllen.

In älteren Zeiten, wo man noch nicht die großen Vortheile Mauerfester Instrumente kannte, bauete man Sternwarten in großen volkreichen Städten; und, um da eine freie Aussicht zu gewinnen, mußte man sich nothwendig über die Dächer der umgebenden Häuser erheben: und auf diese Art entstanden die ObservationsThürme in Paris, in Wien, Berlin, Mannheim, Petersburg, Copenhagen u.s.w. Daß man aber in den neuesten Zeiten, wo die Engländer, und zunächst diesen, der Freyherr von Zach, das astronomische Publikum über die zweckmäßigste Bauart der Sternwarten augenscheinlich belehrt haben, noch auf Thürmen dergleichen Anlagen macht, wie vor wenig Jahren zu Leipzig auf dem hohen Thurm der Pleisenburg geschehen ist: das ist kaum zu entschuldigen.

Bei solchen Thurmförmigen Sternwarten, laßen sich keine bestimmte architektonische Regeln abstrahieren; weil alles den Lokalumständen angepaßt werden muß: selbst der um die Baukunst so verdiente Dr. Stieglitz, hat in seiner Encyclopädie der bürgerlichen Baukunst, aus Mangel an Hülfsquellen, nur wenige allgemeine Regeln über den Bau neuer Sternwarten geben können, sondern sich vorzüglich mit einer genauen Beschreibung der Seeberger Sternwarte, begnügen müssen. Auch ich würde mich nicht an einen so delikaten Gegenstand gewagt haben, wenn ich nicht das seltene Glück gehabt hätte, unter der mündlichen und schriftlichen Leitung zwei berühmter Astronomen, des Freyherrn von Zach und des Hr. Justizraths Schröter die Plane zu der hiesigen neuen Sternwarte zu entwerfen, welche ich Kennern um so unbesorgter als Muster empfehlen darf, da dieselben vor der Ausführung des Baues, der sorgfältigste Prüfung der beiden großen Astronomen, vorgelegt sind.

Nach dieser, von Sr. Königlich Großbritannischen Majestät allergnädigst genehmigten Planen, wurde im Frühjahr 1803 der Anfang mit diesem wichtigen $\mathrm{Bau}$ gemacht. Leider traf aber in diesem Jahr die Hannöverischen Lande das harte Schicksahl, von einem französischen Kriegesheer in Besitz genommen zu werden, welches die Folge hatte, daß alle Königliche Bauten eingestellt wurden; unter welchen eigentlich auch dieser, vor wenig Monaten angefangene Sternwartenbau, begriffen war. Da indessen die Fürstenthümer Grubenhagen und Göttingen anfänglich unbesetzt blieben, und man als wahrscheinlich annahm, daß dieser Zustand nicht von langer Dauer seyn würde: so erhielt ich durch privat Briefe die Anweisung, die angefangenen Arbeiten des Sternwartenbaues, vorerst nicht zu unterbrechen. Demnach wurde nicht nur im Nachsommer 1803, sondern auch im folgenden Jahr der Bau fortgesetzt, und bis zu Terrassenhöhe, oder $6 \mathrm{Fuß}$ hoch über der Erde, aufgeführt.

Während dieser Bauzeit, und besonders in den Wintermonaten, bearbeitete ich diese Abhandlung, und habe dabei, um im Vortrage eine gewisse Ordnung zu beobachten, das Ganze in drei Abschnitte getheilt, und

im ersten gezeigt, worauf bei der Wahl eines Bauplatzes zu einer neuen Sternwarte vorzüglich Bedacht genommen werden müsse, wenn sie den Zwecken der neueren Astronomie entsprechen soll,

der zweite Abschnitt ist der Anlage und inneren Einrichtung, und

der dritte der Ausführung des Baues, gewidmet.

Die lehrreichen Bemerkungen des Freyherrn von Zach über die Nachtheile der ObservationsThürme, und über die astronomischen Bestimmungen in wie fern bei der Wahl eines Bauplatzes, auf einen freien Horizont gesehen werden müsse, können für alle Anlagen dieser Art, als allgemeine Regeln angenommen, und nach der größeren und kleineren Polhöhe eines Orts, modificirt werden.

Nicht weniger wichtig sind die Betrachtungen im zweiten Abschnitt über die verschiedenen Instrumente, welche eine voll- 
[Bild nur Stand. Original einziehen und auf DINA3 Faltseite quer einziehen]

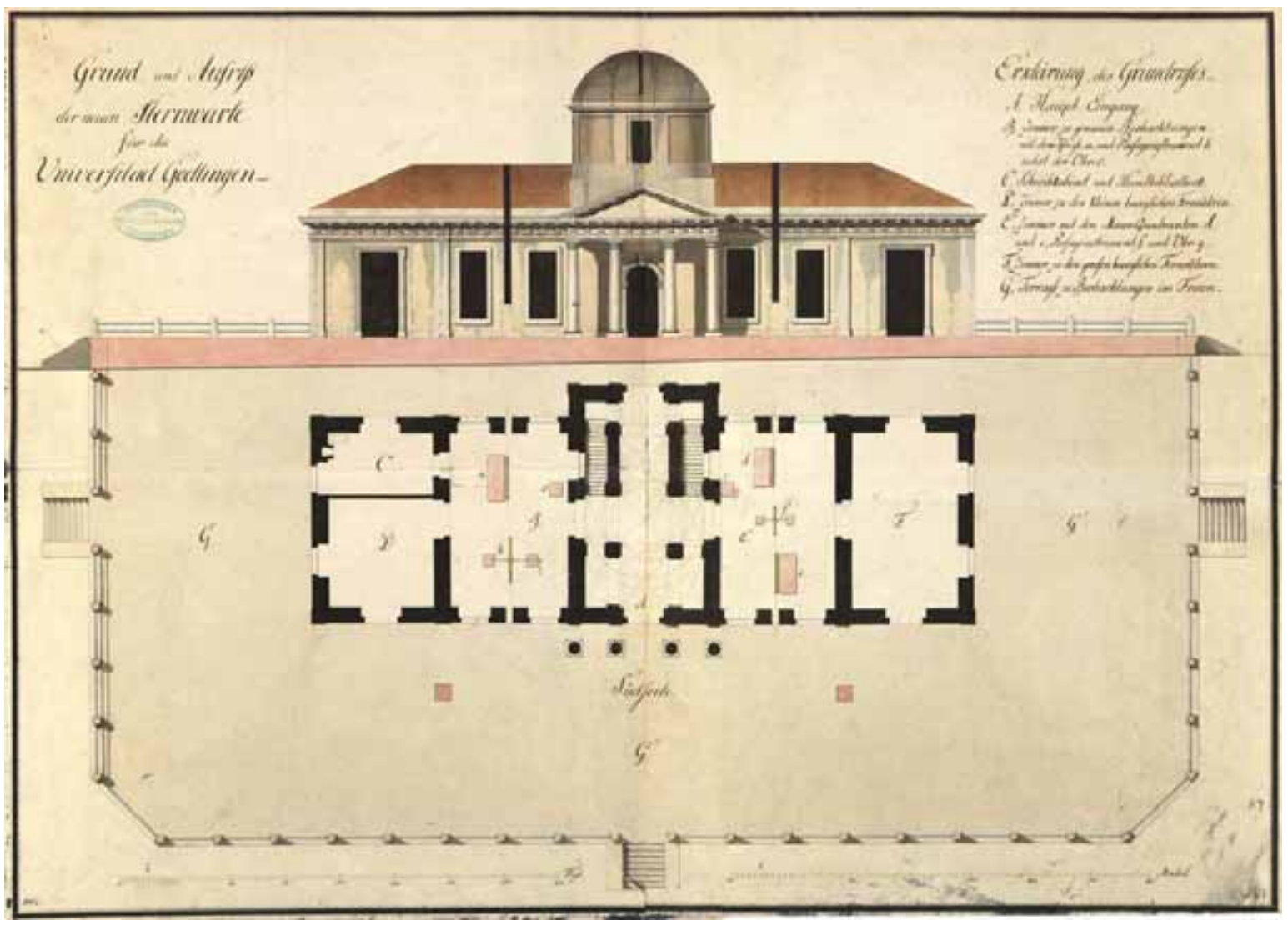






\section{Erster Abschnitt}

Von der Wahl eines zweckmäßigen

Bauplatzes für eine neue Sternwarte.

Eine Sternwarte ist ein Gebäude in welchem so wohl absolute als detachirte Beobachtungen nach allen Himmelsgegenden angestellt werden. Es muß also jede Sternwarte eine solche Lage erhalten, daß der Horizont ganz frei bleibe, damit der Beobachter mit den astronomischen Werkzeugen, das ganze Himmelsgewölbe, übersehen könne. Diese Grundregel leidet aber in einige Ausnahmen. Bekanntlich werden Sternwarten nur selten in beträchtlichen Entfernungen von Städten errichtet; und da ist das Lokal nicht immer von der Beschaffenheit, daß eine nach allen Weltgegenden unbeschränkte Aussicht zu erhalten wäre. Nur in gebirgigten Gegenden wird es möglich, diesen Gebäuden einen solchen Standpunkt anzuweisen, daß dem Beobachter ein nach allen Seiten freier Horizont zu Gebote steht, wenn sich anders eine solche Lage mit dem beabsichtigten Zweck vereinbaren läßt. So konnte z.B. für Gotha, wo der Herzog und die Herzogin sich mit der Astronomie als Lieblingswissenschaft beschäftigen, der Sternwarte keine vortheilhaftere Lage in Rücksicht des überall freien Horizonts gegeben werden, als auf dem, von dem Freyherrn von Zach gewählten Seeberge. Hier wohnt der Astronom gleichsam mitten in seinem Element, entfernt von allen Geräusch der Stadt, und gesichert gegen Ueberlauf unberufener und neugieriger Müssiggänger.

Ganz andere Rücksichten treten bei einer akademischen Sternwarte ein. Diese muß der Regel nach zugleich eine Lehranstalt mit sich vereinigen, durch welche Studierende so wohl theoretischen als praktischen Unterricht in astronomischen Wissenschaften erhalten sollen; ein Zweck, der nur sehr unvollkommen würde erreicht werden, wenn die Sternwarte von den übrigen akademischen Lehranstalten beträchtlich entfernt wäre.

Es muß also als Grundsatz angenommen werden: daß eine academische Sternwarte in der
Stadt selbst, oder, wo dieses wegen des Lokale Schwierigkeiten findet, doch bei derselben, so nahe liegen müsse, daß sie, als in Verbindung mit den übrigen Anstalten stehend, angesehen werden könne.

Bei keinem Gebäude kömmt es auf einen von Natur festen Boden, so sehr an, als bei einer Sternwarte, um für den festen unerschütterlichen Stand der fixen Instrumente gesichert zu seyn. Es $\mathrm{mu} ß$ also hierauf das Augenmerk zuerst gerichtet werden, und neben diesem, nicht so wohl auf eine, in alle Himmelsgegenden durchaus freie, sondern nur auf eine, nach den Lokalumständen möglich freie Aussicht, und vorzüglich mit auf eine bequeme Lage, gesehen werden; damit nicht nur der angestellte Lehrer, sondern auch die mit ihn in Verbindung stehenden und sich übenden Wißbegierigen, so viel es ihre Zeit gestattet, zu jeder Stunde, mit der möglichst größten Bequemlichkeit, die Sternwarte benutzen können. Wie schwer es aber falle, in Städten selbst, diese mäBigen Bedingungen zu erfüllen, beweisen die vielen Thurmförmigen Sternwarten, von deren Unbrauchbarkeit für die jetzige verfeinerte Astronomie, jeder ächte Astronom überzeugt ist. Allein, es kann, sagt der Freyherr von Zach,

„gebieterische Umstände geben, welche aus gewissen Rücksichten, oder aus Oekonomie, wo man schon vorbandene alte Gebände benutzen will, eine solche Bauart rechtfertigen können; vorzuriehen wird sie nie seyn, wo man freie Wabl hat, und da, wo sie gedrängt war, wird man immer Ursache es zu beklagen haben: denn die Erfahrung lehrt, daß Sternwarten, welche das Schicksal haben, auf hohe Gebäude verlegt zu werden, oft den schönsten und wichtigsten Vortheilen der praktischen Sternkunde entsagen, und sie ganz und gar entbehren müssen. Auf einigen können so gar die Haupt-Instrumente nicht aufgestellt und benutzt werden. So konnte z. B. ein fürtrefliches Ramsdensches Passagen-Instrument, das nothwendigste Werkzeng in einer guten Sternwarte, viele Jahre lang auf der Mannbeimer Sternwarte nicht gebraucht werden, weil eine Aufstellung in dem Thurm schlechterdings unmöglich war; es mußte also ein besonderes Nebengebände dazu aufgeführt werden. Der scböne Birdische Mauerquadrant derselben Sternwarte, hängt im obersten Stockwerke des Gebäudes, an einer so wandelbaren Mauer, daß nach Aussage der dortigen Astronomen, dieses fest seyn sollende Werkzeng, immerwährenden Veränderungen unterworfen ist, und das Instrument einer fortdauernden Berichtigung bedarf, welche dessen Gebrauch böchst un₹uverlässig macht.

Zu Petersburg lag ein prächtiger 8füssiger englischer Mauerquadrant 30 Jahre lang in seiner Kiste ungenutzt, 
weil man dieses schwere Werkzeug nicht 120 Stuffen boch, im vierten Stockwerk der Sternwarte aufstellen wollte. Der Astronom Henry wagte es jedoch; allein Euler fand sehr bald, daß dieses Mauerfeste Instrument, so wie es aufgestellt ist, nicht mehr Dienste leiste, als ein gewöhnlicher beweglicher Quadrant.

Auf der Berliner Sternwarte, konnte man kein Passagen-Instrument aufstellen, welches den ununterbrochenen Meridian, vom südlichen bis zum nördlichen Horizont, beschrieben hätte; man mußte daher, um den nördlichen Himmel zu gewinnen, statt einem, zwei solche Mittags-Fernröhre aufstellen. Allein einer der schönsten Vortheile geht nun dabei verlobren, nämlich, sich der Lage des Fernrobrs bei Durchgängen hellerer Sterne, über und unter dem Pole, zu versichern.

Es müssen daher alle Sternwarten, welche auf Thürmen oder hohen Gebäuden angelegt sind, nicht nur grosse und wichtige Vortheile entbehren, sondern auch die Festigkeit und Sicherheit der Werk,zenge leidet dadurch sehr. Die Franzosen haben daber ibren prächtigen Thurm in Paris, oder das eigentliche Observatorium lieber ganz. verlassen, und kleine Nebengebäude zu ebener Erde anzubauen, vorgezogen; wo jetzt die Instrumente aufgestellt sind, und alle Beobachtungen gemacht werden. Alles dieses dient zum Beweise, mit welcher Behutsamkeit und Ueberlegung bei der Wabl eines Bauplatzes müsse verfahren werden, um ähnlichen Nachtheilen und Feblern auszuweichen, welche in der Folge unabänderlich seyn würden. "

Für Göttingen trat ebenfalls der schwierige Fall ein, in der Stadt eine schickliche Stelle, für eine den jetzigen astronomischen Bedürfnissen angemessene Sternwarte, aufzufinden; und man würde sich der absoluten Nothwendigkeit haben fügen müssen, ein Gebäude mit einem beträchtlich hohen Unterbau aufzuführen, um nur einigermassen eine freie Aussicht nach Osten Süden und Westen zu gewinnen, wenn sich nicht ein zweckmässiger Platz nahe vor dem südlichen Thore gefunden hätte, der die Anlage einer Sternwarte nach der neuesten Art, d.h. wo die Instrumente zu ebener Erde aufgestellt sind, wie zu Oxford und Seeberg, erbauet werden konnte.

Ueber die astronomischen Rücksichten bei der Wahl eines Bauplatzes, in Beziehung auf die Göttinger Sternwarte, bemerkt der Freyherr von Zach folgendes:

„Es ist ein riemlich allgemein herrschender Wabn bei Anlegung von Sternwarten, daß man auf solchen eine ganz. unbeschränkte Aussicht über das ganze Gebiet des Horizonts haben müsse; und daß ein mit Bergen umgebener Ort, minder geschickt zu einer solchen Anlage sey. Im Hochgebirge, oder in einem Schweizerthale, würde eine
Sternwarte allerdings am unrechten Orte stehen. Wenn aber an einem Orte der sichtbare Horizont in einer solchen Entfernung von einem Kettengebirge begränzt wird, daß davon nicht mebr als ein Raum von 4 bis 5 Graden am Himmel bedeckt wird, so ist ein solcher Ort deshalb nicht minder geschick.t, der Standpunk. einer Sternwarte zu werden. Dem Astronomen sind nicht alle Theile des Himmels, nicht alle Punkte des Horizonts gleich wichtig; und da die Meinung allgemein ist, daß der Astronom unumgänglich über einen ganz freien irdischen Horizont berrschen müsse, so will ich mich hierüber etwas näher und kunstmässig erk.lären.

Der wichtigste und vorzüglichste Theil des gestirnten Himmels, auf welchen ein praktischer Astronom zuerst zu sehen hat, ist jener der Mittagsfläche. In dieser muß er, bis auf einen gewissen Punkt, freie und ungehinderte Aussicht haben, weil in dieser Richtung die wichtigsten, die vornehmsten, und für den Fortgang, und zur Vervollkommnung der Wissenschaft am meisten geeigneten Beobachtungen gemacht werden. Die astronomischen Werk.zeuge, welche dazu gebraucht werden, sind die eigentlichen Meß-Instrumente, oder die fixen Mauerfesten Werk.zenge, welche man nicht solide und behutsam genug aufstellen kann. Es muß also von Seiten des Baumeisters dafür gesorgt werden, daß diese Werkzenge einen festen und unwandelbaren Grund und Stand erhalten. Der Astronom sorgt aber dafür, daß er in dieser Fläche vom Südpunkte bis zum Nordpunkte des Horizonts, eine freie und ungehinderte Aussicht insonderheit für das sogenannte Passagen-Instrument, erhalte. Es ist aber, wie schon oben erwähnt worden, nicht durchaus nothwendig daß der irdische Horizont einer Sternwarte so rein abgeschnitten sey, wie ein See-Horizont. Gebirge können daher noch einen beträchtlichen Theil des Himmels bedecken, obne daß hieraus der allergeringste Nachtheil für das vollkommenste Bedürfnis einer Sternwarte erwachse. Es kömt demnach blos hierauf an zu bestimmen, in welcher Höhe vom Horizont, unsere Beobachtungen beginnen nothwendig und brauchbar zu werden.

Bei Meridian-Instrumenten haben meines Erachtens nur zwei Nothwendigkeiten dieser Art statt. Die erste ist, daß man mit diesen Werk.zengen, alle planetarische Himmelskörper, zu allen Jabreszeiten und in jeder Lage ibrer Bahnen, ungebindert muß erreichen und beobachten können. Die zweite, daß man diejenigen Fixsterne, welche im Zenith des Beobachtungs-Orts culminiren, noch ungehindert in ibrer Mediation unter dem Pole beobachten könne.

Die erste Nothwendigkeit leuchtet von selbst ein, weil natürlich der ganz einfache Zweck der praktischen Sternkunde ist, den Lauf der Planeten zu beobachten, um dadurch ibre Theorien und Tafeln nach und nach qu verbessern. Da die wichtigsten und bedeutendsten Beobachtungen, welche in gewisse Punkte der planetarischen 
Bahnen fallen, auch auf alle mögliche Punkte des südlichen Mittagskereises fallen können, so ist begreiflich und natürlich, daß dieser auch allenthalben frei seyn müsse.

Die zweite Nothwendigkeit, daß man Fixsterne über und unter dem Weltpole bei ibrer Culmination soll beobachten können, betrifft das Passagen-Instrument allein. Dies ist das einzige, sicherste und einfachste Mittel, sich der so schwierigen Berichtigung und wabren Lage einer Sternwarte zu versichern. Alle andern Methoden um dieses zu erreichen, setzen schon gewisse, nicht immer zu erhaltende Bedingnisse voraus: man muß sich dabei auf Beobachtungen anderer Astronomen, oder auf ibre SternBestimmungen verlassen; oder auch, man muß von dem Gang und Stande seiner Ubr sehr genau unterrichtet seyn, und ibre Anomalien gut kennen. Diese kann man aber nur sicher kennen lernen, wenn das Instrument schon in der vollkommensten Meridian-Lage ist, welches man aber eben zu erforschen gedenk.t. Man sieht daher, daß bei diesen Methoden gleichsam eine petitio principii zum Grunde liegt, und daß, um doch endlich zum Zweck zu gelangen, man sich einer regula falsi und eines unsichern Tatonnements bedienen müsse. Alle diese Bedenklichkeiten fallen weg, wenn ein Passagen-Instrument eine solche Exposition erhält, daß man circumpolar-Sterne über und unter dem Pole, und südliche Sterne mit den nördlichen durch Beobachtungen verbinden kann; wodurch man sich unmittelbar, ohne fremder Beibülfe, und obne sich auf Ubren, oder Stern-Katalogen verlassen zu dürfen, sich der wahren Meridian-Lage des Mittags-Fernrohrs, vollkommen versichern kann.

Wir wollen nun sehen, in wie fern der Göttinger Horizont und ihre Meridian-Fläche, einem solchen unumgänglichen Bedürnis Genüge leiste.

Die größte möglichste südliche Abweichung eines Planeten, bestimmt eigentlich die Gränzen, wie weit ein Horizont frei seyn müsse, um einen solchen Weltkörper noch beobachten zu können. Unter allen bisher bekannten Planeten, war es die Venus, welche die größte Breite erreicht, wegen ihrer großen Nähe bei der Erde; und wenn die Umstände zugleich zusammentreffen, daß die untere Zusammenkunft mit der Sonne in ibren Gränzen sich ereignet, und die Erde in ihrem perihelio ist. Diese Breite kann auf 8 bis 9 1/4 Grade gehen. In künftigen Jahrbunderten, kann sie noch grösser werden, wenn die Apheliums dieses Planeten mit jener des periheliums unserer Erde so zusammentreffen, daß sie die Entfernung der $V$ enus von der Erde noch kleiner; und folglich die geometrische Breite noch grösser machen. Allein seit der Entdeckung des allerneuesten Planeten Ceres Ferdinandea, scheint nun diese die größte Neigung der Bahn zu haben, und daher die größte Abweichung vom Äquator erreichen zu können. So weit wir bisher die Bahn dieses neuen kaum beobachteten Weltkörpers kennen, dürte ibre größte Breite wohl auf 19 bis 20 Grade sich belaufen. Wir wollen zu grösserer Sicherheit 22 Grade annehmen; so wird dieser Planet bei einer solchen südlichen Breite, in Göttingen schon unter dem Horizonte durch den Meridian gehen, und daher gar nicht mehr sichtbar seyn: aber auch schon wegen der Schwäche des Lichts, womit dieser kleine Planet glänzt, würde er auch in einer Höhe von 8 bis 10 Graden in den Dünsten des Horizonts Kaum sichtbar seyn. Folglich können daselbst zu allen Zeiten, und in allen Umständen, alle planetarische Weltkörper frei und ungehindert beobachtet, und die beiden vorzüglichsten Werk.zenge, das Passagen-Instrument und der Mauerquadrant, jederzeit, und unter gar keiner Einschränkung, gebraucht werden.

Tiefere Beobachtungen als die so eben erwähnten, sind kein dringendes Bedürnis mehr, für die praktische Sternkunde; und ich kenne nur einen Fall, wo dergleichen nöthig seyn könnten; wenn man nämlich Untersuchungen über die Strablen-Brechung, anstellen wollte; aber selbst in diesem Fall, würde der Göttinger Horizont, diesen und ähnlichen horizontal-Untersuchungen kein Hinderniß in den Weg legen: denn das, was diese Gebirgs-Kette an Raum im Himmel einnimmt, bleibt immer zu unbedeutend, als daß es hier ernstlich in Anschlag kommen dürfte. Den sichersten Beweis davon gewähren uns selbst die Refractions-Beobachtungen des unsterblichen Tobias Mayer, welcher von dem Standpunkte der alten Sternwarte, wie allen Astronomen bekannt ist, aus eigenen Beobachtungen fürtrefliche Refractions Tafeln entworfen hat, welche mit den Bradleyschen so nabe überein gekommen sind, daß sie noch jetzt für die besten gelten, und die Bewunderung aller Astronomen verdient haben. Also von dieser Seite bleibt gegen den Göttinger Süd-Horizont vom Standpunkte der neu anzulegenden Sternwarte, gar keine Einwendung übrig.

$W$ as den nördlichen Horizont betrifft, so muß dieser in der Mittagsfläche einer Sternwarte in so fern frei seyn, daß an dem daselbst aufgestellten Passagen-Instrumente, die Culmination der circumpolar-Sterne über und unter dem Pole beobachtet werden könne. Allein die Wabl solcher Sterne, welche hiezu am geschicktesten sind, ist nicht willkürlich; sie ist sogar sehr beschränkt. Erstens können nur solche Sterne dazu gebraucht werden, welche für den Göttinger Horizont nie untergehen. Zweitens, können nur grössere und bellere Sterne dazu gewählt werden, welche man auch am bellen Tage und in den Dämmerungen beobachten kann; denn da die beiden Culminationen über und unter dem Pole, jederzeit 12 Stunden von einander entfernt sind, so wird die eine Culmination meistens bei Tage oder beide, zwischen zwei Dämmerungen, einfallen. Drittens müssen diese Sterne nicht zu nabe am Pole seyn; denn da bekanntlich die scheinbare Geschwindigkeit, mit der Sterne durch den 
Meridian gehen, wie die Cosinusse der Declinationen dieser Sterne abnebmen, und im Pole selbst sogar zum Stillstand kommen, so erhält man die Zeitmomente der Culminationen desto unsicherer, je näher der Stern am Pole ist, hingegen desto genauer, je mehr er davon entfernt stehet. Diese Sicherheit, diese Genanigkeit ist alsdann dieselbe, mit welcher man sich der wahren Meridianlage des Passagen-Instruments versichern kann; zu welchem Zweck eigentlich diese Beobachtungen angestellt werden müssen.

Die Gränzen dieser Sternen-Auswahl sind demnach durch ibre Grösse, und durch ibre Polardistanz genau bestimmt. Es gibt zwar mebrere Sterne am gestirnten Himmel, welche diese Bedingnisse in den Dämmerungen erfüllen; allein es gibt deren im ganzen Sternen Heer, für unser nördliches Deutschland nur zwei, welche derselben bei hellen Tage vollkommen Genüge leisten. Der erste ist die sogenannte Capella, oder der helle Stern im Fuhrmann; der zweite der sogenannte Deneb, oder der helle Stern im Schwan. Beide sind Sterne der ersten und zweiten Grösse, und wegen ihrer grossen Declinationen auch durch mittelmäßige Fernröhre bei Tage sichtbar, und wegen ibrer großen Polardistanz, auch mit mässigen Vergrösserungen noch sebr scharf und genau zu beobachten. In wie fern diese beiden Sterne, für den Göttinger Nord-Horizont geeignet seyn, wird sich aus folgenden abnehmen lassen.

Die Polböhe von Göttingen ist bekantlich 50 Grad 32 Minuten. Die Declination der Capella ist 44 Grad 13 Minuten nördlich; folglich culminirt dieser Stern in Göttingen unter dem Pole, in einer Höhe über den nördlichen Horizont von 7 Grad 19 Minuten. Die Declination von Deneb ist 44 Grad 35 Minuten nördlich; demnach geht dieser Stern durch den Göttinger Nord-Meridian in einer Höhe von 6 Grad 7 Minuten. Beide Sterne werden noch überdies, durch die Wirkung der Strablen-Brechung, durch die 7 bis 8 Minuten gehoben.

Nun noch einige Bemerkungen über die südliche Halbkugel des Himmels. In derselben ereignen sich die vorzüglichsten Erscheinungen, und alle die HimmelsBegebenheiten, auf welche ein sorgfältiger Beobachter, stets ein wachsames Auge haben muß. Sonnen- und MondFinsternisse, Vorübergänge der oberen Planeten vor der Sonnenscheibe, Bedeckungen der Planeten und Sterne vom Monde, Jupiters-Trabanten-Verfinsterungen u.d.m. können sich nur in diesem Himmels Raume zutragen. In dieser Himmels-Zone von der größten Amplitudo ortiva bis zur größten Amplitudo occidua, von der größten südlichen, bis zur größten nördlichen Abweichung, gibt es keinen Punkt in derselben, wo nicht eines dieser Ereignisse dermahlen statt haben könnte. Es erheben sich zwar in einigen Theilen dieses Horizonts, Gebirgs-Rücken, welche einen etwas grösseren Raum am Himmel einnehmen; allein dieser ist sicher nirgend von einem Belange, daß er als ein Nachtheil oder als ein Hinderniß für diese Gattung von Beobachtungen, angesehen werden könnte. Die Unwahrscheinlichkeit, daß irgendein solcher Bergkamm, eine sebr bedeutende Beobachtung dieser Art verhindern könnte, ist so groß, daß sich vieleicht ein solcher Zufall in vielen Jahrbunderten nicht ereignen dürfte. Ja man könnte eine solche Einwendung gegen den Göttinger Horizont, geradezu für nichtig erklären, da, wenn auch wirklich ein solcher Fall eintreten sollte, Beobachtungen so nabe am Horizonte, und in den Dünsten desselben angestellt, bekantlich keinen solchen Werth haben, daß man ibren $V$ erlust qu bedauern Ursach hätte, oder denselben wobl gar beträchtliche, von einer andern Seite mehr zu beklagende Aufopferungen machen sollte. Ich appuyire hier auf diesen Grund um so mehr, da bekantlich die obere Spitze des Hainbergs als ein Standpunkt für die neu zu erbauende Sternwarte in Vorschlag gekommen ist. Es bedarf wohl keines Beweises, wie wenig es sich mit dem Dienste und mit dem Vortheil der Universität verträgt, daß eine öffentliche mit einem Lebramte verbundene akademische Anstalt, in eine beträchtliche, von sonstigen litterarischen und oekonomischen Hülfsmitteln abgesonderte Entfernung verlegt werde, besonders wenn dies obne Noth, und obne gebieterische und unabänderliche Umstände veranlaßt, geschehen sollte. Das Beispiel der Seeberger Sternwarte, welche ebenfalls in einer ziemlichen Entfernung von der Stadt Gotha auf einer Anböhe erbauet ist, kann hier nicht zum Vorwand dienen. Diese Sternwarte ist mit keiner Lehranstalt verbunden, sie ist blosse PrivatLiebhaberei eines Fürsten; der solche aus eigenen Chatoullgeldern gebauet und ausgerüstet hat; sie ist zu keiner öffentlichen Anstalt erhoben, und derjenige, dem dieser Fürst die Direktion und Aufsicht dieser stattlichen Sternwarte anvertraut, hat weder Pflichten noch Vorschriften auf derselben zu beobachten, was er thut, geschieht ebenfalls aus Privat-Liebhaberei, alles was geschieht, geschieht blos zum Vergnügen." 


\section{Zweiter Abschnitt}

Über die zweckmäßige Anlage und innere Einrichtung einer Sternwarte

Die gründliche Darstellung des Freyherrn von Zach über die, bei der hiesigen neuen Sternwarte zu erreichenden Zwecke, verdient hier, um so mehr wörtlich angeführt zu werden, da sich hieraus alle die astronomischen und architektonischen Regeln herleiten lassen, welche bei der Anlage und innern Einrichtung einer Sternwarte zum Grunde gelegt werden müssen.

„Ich betrachte“, sagt dieser grosse Astronom, „die Göttinger Universitäts Sternwarte unter den jetzigen Umständen und Bedürfnissen, in einem dreifachen Gesichtspunkt.

Erstlich denke ich mir solche, als eine scientifische Anstalt, durch welche für das Beste und zum Fortgang dieser Wissenschaft gearbeitet, und zu ibrer stets grösseren Vervollkommung unermüdet, und durch fortgesetzte Bemühungen beigetragen werden soll.

Zweitens sehe ich in derselben eine akademische Lehranstalt, in welcher nicht nur die studirende Jugend überhaupt, sondern auch junge Männer, welche sich der Schiffarth widmen, oder Ingenieurs oder Landmesser welche sich zu großen trigonometrisch-astronomischen LandesVermessungen qualifiziven wollen, nicht so wobl den theoretischen, sondern den bisher allenthalben noch mangelnden praktischen Unterricht erbalten können. Noch bisher ist meines Wissens in ganz. Deutschland - vielleicht in ganz Europa - Keine solche Anstalt, wo junge Leute wissenschaftlich, nach einer gewissen Methode, und nach dem neuesten Zustand dieser Wissenschaft, in der ausübenden Sternkunde angeleitet, in der Kunst zu beobachten angeführt, und in dem astronomischen Calcul des praktischen Astronomen, unterrichtet werden. Die astronomische Beobachtungskunst, kann nicht immer durch Bücher erlernt werden, so wenig als man das Accouchiren und die chirurgischen Operationen aus Büchern erlernt; es mu $\beta$ durch Anschauen und Vorzeigen erlernt werden. Man hat daher auf wobl eingerichteten Universitäten, Accouchir- und Kranken-Häuser, so wie anatomische Theater; in äbnlicher Hinsicht soll man daber auch astronomische Observatoria baben.
Drittens. Nachdem Sr. Königl. Großbrith. Majestät den grossen Apparat des Herrn Justizraths Schröter, für die Göttinger Sternwarte angekauft haben, so muß natürlich bei der Anlage einer neuen Sternwarte, auch für ibre Unterbringung gesorgt werden.

$W$ as den ersten Punkt betrift, so ist natürlich, daß, wenn man bei dem heutigen Zustand der astronomischen Wissenschaften, derselben beitragen soll, man auch mit den nöthigen Hilfsmitteln ausgerïstet seyn muß, um diesem Zweck zu erreichen. Wenn in unsern Tagen die verfeinerte praktische Sternkunde mit der so sehr vervollkommneten Theorie derselben, gleichen Schritt gehen soll; wenn die neu zu erbauende Göttinger Sternwarte in der That zur weitern Ausbildung und Fortschreitung in dieser Wissenschaft beitragen, und bei der Concurenz der

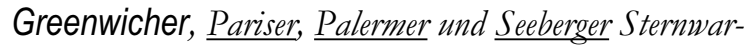
te, ebrenvoll und mit Nutzen bestehen soll: so muß sie nothwendig auch mit solchen Werkzengen ausgerïstet werden, mit welchen sich dieses Ziel er reichen läßt. Bevor also von dem Bau und der innern Einrichtung einer Sternwarte die Rede seyn kann, müssen erst die Gattungen und die Dimensionen der Instrumente, welche darin aufgestellt und gebraucht werden sollen, bekannt seyn, weil sich die Anlage des Gebäudes nach der Grösse und dem Bedürfniß dieser Werkzenge richten muß.

Ich theile diese Werkzenge in zwei Classen, in solche welche zum Messen, und in andere welche nur zum

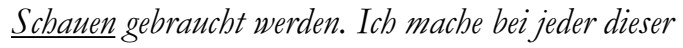
Classen noch eine Unterabtheilung, in solche welche nur für den wirklich dabei angestellten praktischen Astronomen und Observator zum Gebrauch bestimmt sind; diese müssen von der grössern und vollkommenern Gattung seyn, weil damit für die Erweiterung der Wissenschaft gearbeitet werden soll: in andere von der kleineren und geringeren Gattung, wo junge angehende Astronomen ibre ersten Uebungen machen, und ibren Unterricht dabei empfangen können, theils weil man ibren noch ungeübten Händen, die grössern und kostbaren Instrumente nicht so bald anvertrauen kann, theils weil sie dadurch eine angefangene Reibe sorgfältiger Beobachtungen des wirklichen Astronomen stöbren, verderben oder bindern könnten. Nur diejenigen, welche sich mit der Zeit Geschicklichkeit und Festigkeit in der Beobacbtungskunst erworben haben, könnten, nach Gutbefinden ibres Lebrers, ž den grössern Instrumenten zugelassen werden, und dabei die Vollendung ibrer Ausbildung erbalten.

Das erste und vorzüglichste Meß-Instrument in einer wobl eingericbteten Sternwarte, ist das PassagenInstrument, oder das Mittags-Fernrohr. Es dient zu zweierlei Behuf:

1, zur wabren Zeitbestimmung, der Maaßstab aller himmlischen Bewegungen und Wabrnebmungen; 


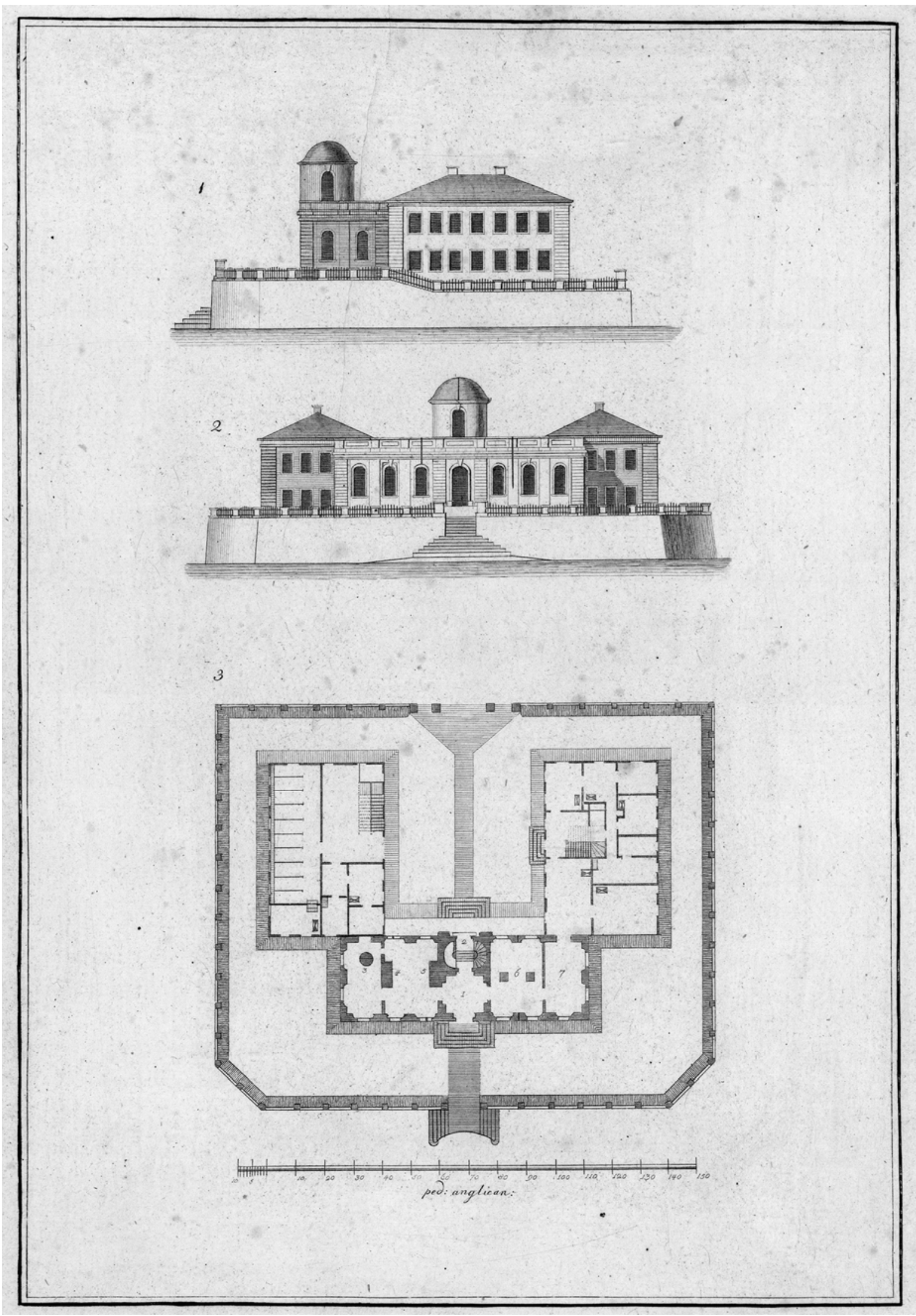

Abb. 23: Kupferstich der Ansicht und des Grundrisses der Gothaer Herzoglichen Sternwarte auf dem Seeberg, deren Direktor Franz Xaver von Zach war. Die Seeberger Sternwarte (abgerissen 1858) ist das Vorbild der Göttinger Sternwarte und wurde selbst wiederum von Zach aufgrund seiner Kenntnis der Radcliffeschen Sternwarte in Oxford entworfen. Aus dem CATALOGUS NOVUS von F. X. von Zach, Gotha 1792. 
2, zur Bestimmung der sogenannten geraden Aufsteigungen aller bimmlischen Weltkörper.

Das erste gibt das wabre Zeitmoment, letateres den wahren Ort des beobachteten Gestirns in der Richtung von Osten nach Westen, im Weltraum.

Um mit diesem Werk.zenge die bei dem jetrigen Verlangen der Wissenschaft, erforderlichen Beobachtungen zu machen, muß es von einer solchen Grösse und Güte seyn, daß man die Zeitbestimmung damit, bis auf zwei Zehntheil einer Zeitsekunde, und die geraden Aufsteigungen, bis auf drei oder vier Raumsekunden, muß beobachten können. Die optische Eigenschaft dieses Fernrohrs muß so beschaffen seyn, daß man Sterne der ersten Grösse zu allen Tageszeiten damit muß seben und beobachten können. Diese Bedingnisse schließen alsdann alle übrigen mit ein, welche man bei den übrigen Gestirn- und planetarischen Weltkörpern voraussetzen kann. Aber um diese zu erreichen, darf ein solches achromatisches Fernrohr, keine geringere Oeffnung, als drei englische Zoll, und keine geringere Brennweite, als böchstens 5 bis 6 englische Fuß haben, wenn es lichtstark genug seyn, und stärkere Vergrösserungen mit Deutlichkeit vertragen soll. $W$ as über diese Maaßen hinaus geht, ist desto besser, was unter denselben seyn würde, dürfte allen bekannten Werkzengen dieser Art, nachstehen.

Diejenigen Sternwarten, welche die grössten und besten Instrumente haben, nämlich 8 Fuß Fokallänge, 4 Fuß die Axe, und 4 Zoll Oeffnung, sind folgende: Greenwich, Oxford, Richmond, Blenheim und Seeberg. Nur das Oxforder Fernrohr, ist bei den übrigen Dimensionen um 2 Fuß länger. Passagen-Instrumente von 6 Fuß, besitzt nur die Dubliner Sternwarte, von 5 Fuß die Gothaische Interims-Schloß-Sternwarte, die Mannheimer, die Palermer; von 3 1/2 und 3 Fuß, die

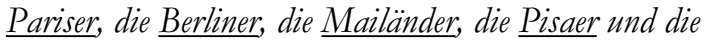
Wilnaer. Die übrigen Sternwarten entbehren dieses Haupt-Instrument entweder ganz und gar, oder sie sind nur von solcher Beschaffenheit, daß sie mit den erwähnten in gar keinen Vergleich zu setzen sind.

Hieraus wird es einleuchtend, daß für die neue Sternwarte in Göttingen, ein solches Fernrohr nicht unter 5 Fuß Fokallänge betragen dürfe. Ein solches Instrument würde etwa auf 120 Guinees zu stehen kommen. Das auf der Seeberger Sternwarte befindliche 8-füssige vom seel. Ramsden verfertigte, in seiner Art einzige Werkzeng, kam auf 220 Guinees. Das Oxforder Mittagsrohr, obgleich zwei Fuß länger, und von Bird verfertigt, kostete nur 150 Guinees; allein es hat die mannigfaltigen neuen Einrichtungen und Verbesserungen nicht, welche jetzt bei diesen Werkzengen angebracht sind, wie z. $B$. die Beleuchtung der Fäden durch die Axen, die FrictionsRollen in den Pfannen, die beweglichen Oculare u.s.w.
Zur Uebung für die astronomischen Zöglinge, würde ein Kleines Passagen-Instrument von etwa zwei Fuß binreichend seyn. Wolte man hiebei auf Oekonomie sehen, so brauchte das Objectiv nicht achromatisch, und das Werkzeng selbst, statt von Messing, nur von weissem Blech zu seyn, dergleichen, selbst auf der Cambridger Sternwarte sind, womit der berühmte Ludlam, nicht ganz. schlechte Beobachtungen angestellt hat: allein meiner Meinung nach, wäre hier Ersparniß am unrechten Orte, es kömmt dabei kein grosser Gewinn heraus; denn gar zu schlecht dürfen die Werkzenge doch auch nicht seyn, wenn der Anfänger damit gute Beobachtungen zu machen lernen soll. Ein kleines Passagen-Instrument von 27 Zoll Brennweite, 24 Zoll Axe achromatisch, womit ich den Merkur sebr oft, und Sterne der ersten Grösse, eine balbe Stunde vor der Sonne beobachtet hatte, von Ramsden ganz in Messing verfertigt, kostete nur 30 Guinees. Ein solches Instrument wäre zum praktischen Unterricht äusserst brauchbar: an welchem die Anfänger nicht allein die Theorie dieses Instruments, sondern auch dessen verschiedene Berichtigungen erlernen, und selbst ausüben, und dabei noch brauchbare Beobachtungen anstellen könnten; wenn solche nicht unter gewissen schwierigen Umständen zu machen sind, welches man alsdann den grösseren Werkzeugen überlassen muß, und daher nichts auf sich hat, wenn solche von den ersten Anfängern übergangen werden. So wie das Passagen-Instrument das Haupt-Meridian-Meßwerk zeng ist, womit alle Zeit- und Ortsbestimmungen der bimmlischen Körper in der Richtung von Osten nach Westen gemacht werden: eben so ist der Mauerquadrant oder der ganze Kreis, das fixe Meridian-Meßinstrument, womit diese Ortsbestimmungen in der Richtung von Süden nach Norden gemacht werden. Beide Werkzenge müssen stets verbunden seyn: sie sind das erste und Hauptbedürfnis einer wohleingerichteten Sternwarte; weil durch diese $V$ erbindung allein, die besten, und die einzig vorzüglichen Beobachtungen vollbracht werden. Da wo diese beiden Instrumente gebörig und solide aufgestellt sind, bleibt in dieser Rücksicht nichts besseres zu wünschen übrig.

Zwischen den genanten beiden Werk.zeugen, dem Mauerquadranten oder dem ganzen Kreis, ist die Wabl nicht gleichgültig.

Noch vor 10 oder 12 Jahren, kannte man keinen ganzen Meridian-Kreis; die grossen 6 und 8 füssigen Mauerquadranten, waren damals üblich: und da man mit einem solchen Quadranten, nur in einem Halbkereis des Meridians beobachten kann; so werden deren allemal zwei erfordert, um damit im ganzen Mittagskreise beobachten zu können. In grossen wohlversehenen Sternwarten, waren daher ein südlicher und ein nördlicher Mauerquadrant. Da aber diese Werk.zenge überaus kostbar sind, so sind meines Wissens in ganz. Europa nur zwei Sternwarten, 
welche diesen Vortheil haben, mit zwei Mauerquadranten, im ganzen und ununterbrochenen Meridian beobachten zu können. Diese beiden Sternwarten sind die Greenwicher und Oxforder: erstere hat auch nur einen mittelmässigen Nordquadranten, dessen Gerippe von Eisen ist; nur Oxford hat zwei vortrefliche Birdische 8füssige Mauerquadranten ganz von Messing, welche zusammen 800 Guinees kosteten. Seit einigen Jahren besitzt die Pariser National-Sternwarte auch qwei Mauerquadranten; der nördliche ist aber von kleinerer und mittelmässiger Gattung, welches ebenfalls bei der Mailänder Sternwarte der Fall ist. Sonst gibt es wohl noch mebrere gute 8 und Gfüssige Birdische und Ramsdensche
Mauerquadranten, als in der Militair-Schule zu Paris, in Blenheim, in Padua, in Göttingen, in Mannheim, in Wien und Petersburg. Allein sie sind überall nur einseitig, und müssen, wenn sie nördlich gebraucht werden sollen, mit vielen Umständen, und für so schwere Instrumente, nicht ohne Gefahr, von der südlichen Mauer, an die nördliche, gebracht werden

Aber auch zwei Mauerquadranten sind zur Vollständigkeit nicht hinlänglich: sie ziehen noch ein drittes Werk.zeng nothwendig nach sich, welches zur Stellung und Berichtigung dieser Quadranten dient; und dieses ist der sogenannte Zenith-Sektor. Der Oxforder von 12 Fuß und von Sishon verfertigt, kostete 200 Guinees:

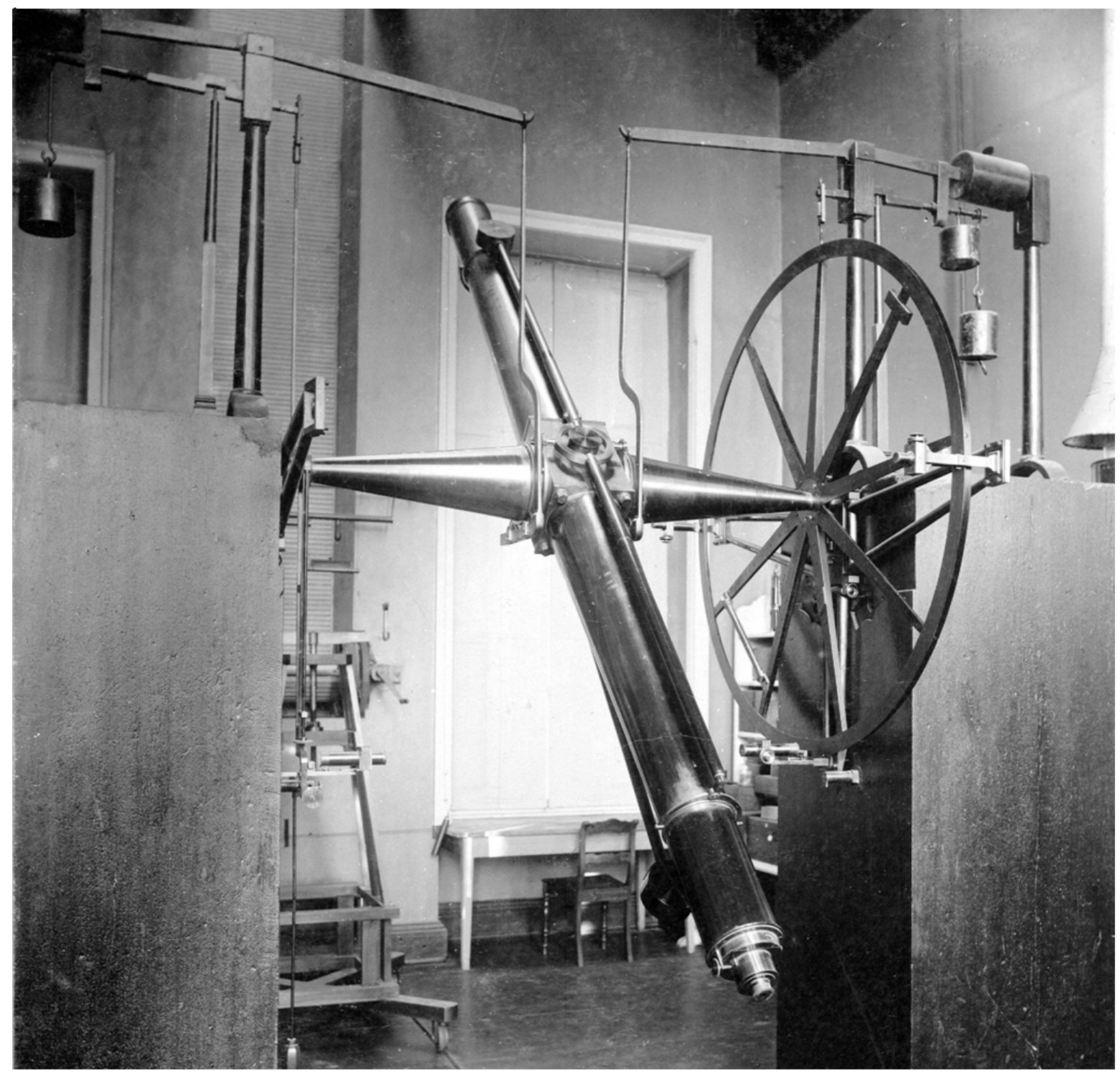

Abb. 24: Meridiankreis von Johann Georg Repsold (1770-1830) in Hamburg. Dieses Instrument wurde 1803 für Repsolds eigene und 1811 von den Franzosen zerstörte Sternwarte gefertigt, von Gauß für die neue Göttinger Sternwarte für 1300 Rtlr. erworben und von Repsold in langwieriger Arbeit 1817 mit einem genaueren Teilkreis versehen (dem „verzweifelten Kreis“ nach Repsolds Bericht). Das Instrument wurde 1818 von Repsold persönlich im östlichen Meridianzimmer aufgestellt. Dies ist der auf S. 63 unten rechts von Borheck erwähnte „ganze Kreis“ (Photo Noelle 1893). 


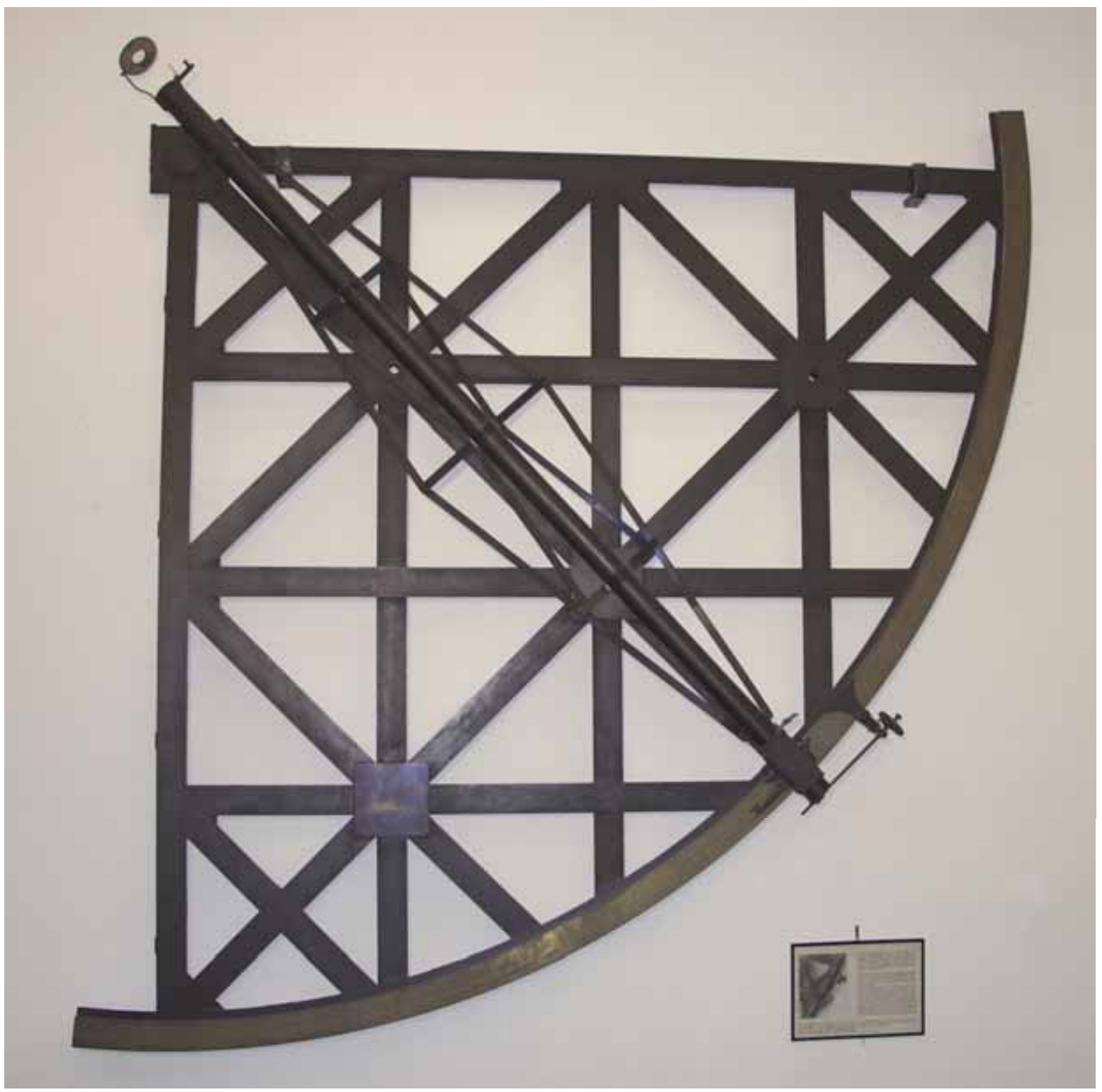

Abb. 25: 6-füßiger Mauerquadrant von John Bird (1709-1776) in London (s. Text S. 67 oben links). Bird war einer der besten Hersteller feinmechanischer Instrumente seiner Zeit. Das Instrument kam 1756 als Geschenk Georgs II nach Göttingen, wo es anfangs in der alten Sternwarte montiert war. Mit diesem Instrument hat Tobias Meyer bis 1758 seinen Zodiakalsternkatalog erstellt (Genauigkeit der Sternpositionen \pm 2 Bogensekunden). Später wurde er von Gauß benutzt und 1817 im östlichen Meridianzimmer an einem Pfeiler montiert. Ein in Gauß' Zeit vorgesehener Ersatz des chromatisch nicht korrigierten Objektivs (s. S. 67) unterblieb, weil der neu angeschaffte und im gleichen Raum untergebrachte Repsoldsche Meridiankreis genauere Messungen zuließ.

Hiernach kann man also rechnen, daß zu den Höhenund Declinations-Beobachtungen, wenn man sich der Mauerquadranten bedienen will, drei Werkezenge nöthig sind, wenn alles vollständig seyn soll; welche zusammen auf 1000 Guinees zu stehen kommen würden. Diese drei so äusserst kostbaren Instrumente sind aber entbehrlich, wenn man sich der heut zu Tage weit vorzuziehenden ganzen Kreise, bedienen will. Sie ersetzen vollkomner und besser die beiden Mauerquadranten, und den Zenith-

Sektor. Ein solcher ganzer Kreis wäre daher für die neue Göttinger Sternwarte unentbehrlich.
Wenn ein ganzer Kreis die drei obgedachten Instrumente vollkommen ersetzen; und wenn der praktische Astronom ferner dabei auf die allerdelikatesten Beobachtungen welche damit zu machen sind, Rücksicht nehmen will, wodurch der Zenith-Sektor durchaus entbehrlich gemacht werden soll: so hat er meines Erachtens auf folgende der allerschwierigsten und wünschenswerthesten Gattungen von Beobachtungen, den Bedacht zu nehmen; eine Arbeit, welche der praktischen Sternkunde noch künftig auszufübren und zu vollenden übrig ist. Der praktische Astronom muß damit die Beobachtungen und Bestimmungen 
1, der Abirrung des Lichts,

2, der Schwenkung unserer Erdaxe,

3, der jährlichen Parallaxe unserer Erdbahn bei Fix sternen,

4, der eigenen Bewegung der Fixsterne,

5, der mittleren Strablenbrechung genau anstellen und vollbringen können. Alle diese Beobachtungen sind noch Desiderata in der Sternkunde. Einige derselben sind seit dem Jahre 1728 nicht wiederbolt worden; andere sind mißlungen. Allein ihre wabre Bestimmung kann man nur von dem heutigen verfeinerten Zustande der praktischen Sternkunde erwarten; wozu vorzüglich die ganze Kreise, eines der wesentlichsten Hülfsmittel sind.

Um aber den vorgesetzten Zweck damit zu erreichen, muß die Beobachtungsgränze eines solchen Werkzenges wenigstens so weit gehen, daß man damit bis auf die Raumsekunde genau beobachten kann. Der einzige bisher aufgestellte und fleissig gebrauchte Kreis dieser Art, ist jener der Palermer Sternwarte; er ist 5 Fuß im Durchmesser von Ramsden verfertigt, und hat 450 Guinees gekostet. Allein aus den Beobachtungen zu schliessen, welche mit diesem Instrument gemacht, und mir bekannt geworden sind, glaube ich nicht annehmen zu dürfen, daß man damit bis auf eine Sekunde genau beobachten könne: man wird daher wenigstens auf einem ganzen Kreis von 8 englischen Fuß Durchmesser rechnen müssen; womit sich allerdings die Raumsekunden noch beobachten lassen, dagegen man bei einem 8füssigen Mauerquadranten immerbin auf 4 bis 5 Sekunden noch unsicher seyn kann. Ein solcher Kreis würde etwa auf 6 bis 7 hundert Guinees zu stehen kommen: denn der bei Ramsden für die Seeberger Sternwarte bestellte 8füssige Kreis, war zu 650 Guinees accordiert, ist aber nicht fertig geworden."

Ausser den Beobachtungen mit den vorhin beschriebenen Instrumenten, kommen in der praktischen Sternkunde Fälle vor, wo Beobachtungen ausserhalb des Meridians unumgänglich nothwendig werden. Dieses sind meistens Beobachtungen von Cometen oder solcher Planeten, welche wegen ihrer Lichtschwäche nicht bei Tage beobachtet werden können, und folglich in ihren Quadraturen im östlichen oder westlichen Himmel vor oder nach der Dämmerung beobachtet werden müssen. Die beste und schicklichste Gattung von Werkzeugen zu diesem Behuf, sind die sogenannten Aequatoreal-Instrumente, oder Aequatoreal-Sectoren.

„Die Aequatoreal-Sectoren sind ebenfalls fixe Instrumente, das ist, sie drehen sich auf einer im Meridian und nach der Polhöhe des Orts befestigten Axe. Sie unterscheiden sich von den Aequatoreal-Instrumenten dadurch, daß diese kleiner und transportabel sind, und an jedem Ort aufgestellt werden können; dagegen die Sectoren auf gemanerte Pfeiler für beständig aufgesetzt werden. Der schönste Aequatoreal-Sektor ist jener, welchen der seel. Ramsden für Sir George Shuckburgh verfertigt, und 400 Guinees gekostet hat. Der Declinations Kreis hält 4 Fuß im Durchmesser, und das Fernrohr ist von einer besonderen Güte. Nächst diesem ist der prächtigste Aequatoreal-Sektor auf Sr. Majestät des Königs Sternwarte in Richmond befindlich. Der Declinations Kreis hat 2 1/2 Fuß. In Greenwich und Oxford sind ebenfalls fürtrefliche Sektoren; letzterere von Sishon hat 200 Guinees gekostet. Der englische Künstler Edw. Troughton verfertigte einen im Jahr 1787 für Portugall, dessen Declinations Kreis 20 Zoll und der Azimuthal-Kreis 34 Zoll bielt, und 280 Guinees kostete. Hieraus lässt sich obngefehr schliessen, von welcher Gattung man einen solchen Sektor für die Göttinger Sternwarte bedarf.

Die neuesten Entdeckungen der Piazzischen Ceres, und der Olbersschen Pallas, machen nunmehr diese Art von Werkzengen doppelt nothwendig: denn diese lichtschwache Weltkörper, werden damit an meisten beobachtet werden müssen. Soll demnach ein solches Instrument wirklich Nutzen gewähren; und soll man damit Beobachtungen anstellen können, welche den Meridian-Beobachtungen an die Seite gesetzt werden dürfen: so muß ein solches Aequatoreal-Werkzeng, besonders ein sehr lichtstarkes grosses achromatisches Fernrobr mit starker Oeffnung mindestens von 4 Zoll haben; und dann dürfte man dessen Preis auf 300 Guinees setzen.

Zur Schonung des Aequatoreal Sektors, weil man eines solchen kostbaren Werkzenges sich nicht zum Suchen, und Abfegen des Himmels bedienen kann, und da man ohnehin auch gute achromatische Fernröhre zu den freien Beobachtungen haben muß, so würde ich noch eine gute parallaktische Maschine vorschlagen. Die größte und schönste Maschine dieser Art, ist jene des Herrn Justizraths Schröter zu Lilienthal. Sie besteht vorzüglich aus einem ganz fürtreflich Dollandschen 10füssigen Achromaten; und da dieses schöne Werkezeng auch dereinst für die Göttinger Sternwarte bestimmt ist, so bleibt in dieser Art nichts besseres zu wünschen übrig.

Um die Vorrichtung zu den fixen MeridianInstrumenten gan ₹ vollständig zu haben, dazu gebört noch eine astronomische Uhr. Daß diese von der bestmöglichsten Gattung seyn müsse, um mit den obbemeldeten Instrumenten im würdigen und nöthigen Verbältniß zu stehen, versteht sich von selbst. Gegenwärtig sind die mit einem Anker von Diamant, auf Edelstein laufende, mit einer Zink-Compensation versehene Arnoldsche Pendelubren, die besten. Eine solche Uhr komt auf 110 bis 120 Guinees zu stehen; so viel kostete die Uhr der Seeberger Sternwarte, und eben so viel eine ähnliche, 
welche erst im Jahr 1802 dahin gekommen ist, ob sie gleich schon 6 Jahre früher bestellt war.

Durch diese Instrumente wäre nun für den Observator hinlänglich gesorgt.

Für die praktische Lebranstalt, würde der, auf der alten Göttinger Sternwarte befindliche Gfüssige Birdsche Mauerquadrant, sebr zweckmässig seyn. Dieses in seiner Art fürtrefliche Werk:zeng, bedarf nur einiger Abänderungen, um das brauchbarste Instrument daraus zu machen. So muß es z.B. mit einem achromatischen Objective versehen werden, welches es nicht hat. Das Ocular muß nach Ramsdens Erfindung zum Verschieben eingerichtet, und das Faden-Netz nach seinem optischen System eingerichtet werden, wie dieser grosse Künstler es in Blenheim bei dem Herzog von Marlborough an den Gfüssigen Muralquadranten angebracht hat. Auch dürfte eine neue Mikrometerschraube daran nöthig seyn, da die alte durch vielen Gebrauch ausgelaufen ist. Dabei könnte man auch Ramsdens sinnreiche Vorrichtung anbringen, den todten Gang dieser Schraube zu verbindern. Eben, weil nach allen diesen Verbesserungen, dieser Quadrant ein ganz. vorzügliches Werk.zeng werden dürtte, wünschte ich, daß das zum Unterricht bestimmte Passagen-Instrument, nicht zu schlecht in seiner Art ausfallen möchte: weil man alsdann, in Verbindung desselben mit diesem verbesserten Quadranten, auch noch vortreffliche und höchst brauchbare Beobachtungen würde anstellen können. Zu diesem Zweck muß auch auf eine nördliche Mauer in der neuen Sternwarte Bedacht genommen werden, um diesen Quadranten nach Norden umzubängen, wenn dessen Rectification den angehenden Astronomen gezeigt und gelehrt werden soll. Hiezu müsste man alsdann einen Transporteur anschaffen, um dieses Geschäfte leicht, und ohne Gefahr volliqiehen zu können.

$Z u$ diesen Instrumenten würde die auf der alten Göttinger Sternwarte befindliche Sheltonische Ubr ganz. vortreflich passen. Die Anfänger würden alsdann nicht damit pfuschern, sondern recht gute und brauchbare Beobachtungen, anstellen können. Noch würde für die Lehranstalt nöthig seyn: ein beweglicher Quadrant, um damit Anfängern Beobachtungen an Polböhen, oder correspondirenden Sonnen- und Sternhöhen, oder terrestrische Winkel aufnebmen zu lehren. Einen dergleichen Sissonschen Quadranten besitzt die Göttinger Sternwarte schon. Hiezu könnten noch einige hölzerne und messingene Hadleysche Sextanten, deren Göttingen einen sebr guten besitzt, nebst künstlichen Horizonten kommen, um Liebhaber, reisende junge Gelehrte, Landmesser, Ingenieurs, Geographen, und selbst junge Seemänner, in dieser Gatuung von Beobachtungen, unterrichten zu können.

Zu den oben beschriebenen AequatorealInstrumenten, zu Beobachtungen ausser dem Meridian, würden noch nöthig werden:
1, Ein Geotheodolite zu geodätischen und trigonometrischen Operationen; obngefähr wie der Ramsdensche, welcher dem General Roy und Major Mudge in der englischen Vermessung und zur Junction der Pariser und Greenwicher Sternwarte gedient hat. Da Sr. Majestät der König eine so stattliche und königliche Sternwarte in Göttingen erbauen lassen, so werden Höchstdieselben als Selbsteigener Kenner dieser Wissenschaften, auch alle die Früchte und den Nutzen erwarten, der bieraus für die geographische, statistische und militairische Länderkunde Ihrer Churfürstlichen Lande erwachsen kann. Man bätte demnach meines Erachtens, auch hierauf zugleich Bedacht zu nebmen; daß wenn Sr. Königliche Majestät dereinst eine astronomisch-trigonometrische Aufnabme des Churfürstenthums und Dero sämtlichen Herzogthümer anzubefehlen geruben sollten, man auch zugleich mit den dazu benöthigten Werkzengen versehen sey; selbst auf den Fall, wenn damit, so wie es in England geschehen, und bei dem heutigen verfeinerten Zustande der geodätischen Operationen unzertrennlich ist, eine so sehr gewünschte, und zu nähern Kentniß der Gestalt unserer Erde so nothwendige Grad-Messung verbunden werden sollte. Der Göttinger Sternwarte darf es demnach an den ausgesuchtesten Hülfsmitteln hierzu, nicht ermangeln.

2, Ein der besten englischen Poket-Chronometer. Ein solches Werkzeng würde nicht allein zu LängenBestimmungen dienen, wenn der Königliche Astronom auf geographische Expeditionen ausgeschickt werden sollte, sondern würde auch als eine sehr gute und bequeme astronomische Ubr bei einer trigonometrischen LandAufnabme zu Beobachtungen des Azimuths und Orientirung des Dreieck-Systems dienen. Jungen Leuten, welche sich der Schiffahrth widmen, oder zu astronomischen Geographen ausbilden wollen, wird man damit Unterricht in der Ausübung der Methode geben, die Länge zur See durch solche Zeithalter zu finden, wie ein Register über ibren täglichen Gang zu halten, der mittlere Gang zu bestimmen, und nach Umständen zu verbessern sey. Dem Astronomen wird eine solche Ubr zum unentbehrlichen Geräthe, wenn er die in verschiedenen Theilen der Sternwarte stehenden Uhren, vergleichen, und die Zeit von einer zur andern übertragen muß. Denn da die Ubr beim Passagen-Instrument diejenige ist, an welcher man die richtigste Zeitbestimmung erbält, so muß von solcher die Zeit an die übrigen Uhren, welche beim Kreis, beim AequatorealSektor, beim parallaktischen Instrument u.s.w. stehen, schnell und mit Sicherheit übergetragen werden können. Auch wenn der Astronom im Freien auf der Terrasse mit grossen Teleskopen beobachten will, so ist es mit nicht geringen Schwierigkeiten verbunden, wenn er die Zeit in einiger Entfernung vom Gebäude aus einem Appartement der Sternwarte, wo eine astronomische Uhr stehet, mit lauter Stimme zugerufen erhalten soll: ein tragbarer 
Taschen-Chronometer hebt diese Schwierigkeit mit einem Mal; und der Astronom führt seine Zeit stets bei sich in allen Theilen des Gebäudes, in und um die Sternwarte, und selbst da, wo es unmöglich wäre im Freien eine astronomische Pendelubr anzubringen und aufzustellen.

3, Einen Troughtonschen oder Mendozaschen Spiegel-Kreis. Da heut zu Tage die Methode der LängenBestimmungen durch Monds-Abstände, durch die Verbesserungen der Monds-Tafeln, immer mehr vervollkommnet; und so wohl zur See als zu Lande immer mehr in Gebrauch gekommen ist: so muß auch für diesen wichtigen Zweig des Navigations-Unterrichts, nichts vernachlässiget werden. Da man mit solchen Spiegel-Kreisen durch Wiederholung und Verdoppelung der Angular-Distanzen des Mondes von der Sonne oder den Fixsternen, solche mit sehr grosser Genanigkeit erhalten kann: so geben bei dem jetzigen neuesten Zustande unserer Monds-Tafeln, solche Beobachtungen sehr gute Mittel an die Hand, zur See wie zu Lande, genaue Längen-Bestimmungen zu machen. Ein solches Werk.zeng kann daher nicht allein in diesen etwas schwierigen Beobachtungs-Methoden, sondern dem dem Astronomen auch zum wirklichen Gebrauch bei geographischen Längen-Bestimmungen dienen. Bekantlich werden auf grossen und wichtigen Seereisen, die beiden Methoden der Längen-Bestimmungen durch Zeithalter und durch Monds-Distanzen immer verbunden, und eine durch die andere verbessert. Noch bisher ist keine Sternwarte ex officio dazu angewiesen, diese für die Schiffahrth so böchst wichtige Beobachtungsart zu verfolgen, zu verbessern, oder nur zu prïfen. Die angewiesene Pflicht des Königl. Astronomen zu Greenwich ist zwar, ununterbrochen Monds-Beobachtungen anzustellen; wodurch man die Mondstafeln verbessern, und das so berühmte Problem der Meereslänge endlich vollkommen auflösen könne. Dieser Zweck ist auch bereits in hohem Grade erreicht worden, durch die unermüdeten Beobachtungen eines Flamstead, Halley, Bradley und Maskelyne, durch die gründliche Monds-Theorie, eines Euler, d'Alembert, Clairaut, La Grange und La Place, und durch die ungeheueren Berechnungen eines Tobias Mayer, Mason und Bürg. Es bleibt uns also nur noch übrig, diese herlichen Arbeiten auf eine, der heutigen verfeinerten praktischen Sternkunde angemessene Art, auf die Erd-und Schiffarths-Kunde anzuwenden, und sie durch Verbesserung der katoptrischen Werkzeuge, auf einen solchen Grad der Vollkommenheit zu bringen, der sich jetzt von unseren so sehr verbesserten Mondstafeln mit Recht erwarten läßt. Dem Göttinger königlichen Astronomen sollte es daher zur Pflicht gemacht werden, die Methode der Monds-Distanzen in anhaltender Prüfung zu erhalten, damit er durch eine vertraute Uebung nach und nach aus eigener Erfahrung die Verbesserungen, so wohl im praktischen als theoretischen Theil, selbst einsehen lerne, und die dientichen Vorschläge zur Vervollkommnung dieser so wichtigen Beobachtungen machen könne. Bei Fortsetzung solcher Beobachtungen wird man wenigstens die Gränz̧en genau kennen lernen, auf welche die Längen-Bestimmung durch diese neuesten Hülfsmittel gebracht worden ist, und was etwa noch zu wünschen, und zu erlangen übrig bleiben sollte.

Diese drei erwähnten Werkzeuge verursachen einen bedeutenden Aufwand: denn bei den Geotheodoliten dürte man wohl keinen geringeren Preis als 150 Guinees ansetzen. Wollte man einen Bordaschen Multiplications-Kreis mit zwei beweglichen Fernröhren zu demselben Behuf anschaffen, so würde einer von drei Fuß im Durchmesser, auf 100 Pistolen zu stehen kommen.

Unter 100 Guinees läßt sich kein brauchbarer Chronometer zu Längen-Bestimmungen anschaffen; es gibt deren aber von der besten Gattung für 120 bis 200 Guinees.

Ein 18 zölliger Spiegel-Kreis, kömmt auf 45 bis 50 Guinees, und die besten 10 zölligen Sextanten, auf 16 bis 20 Guinees zu stehen.

$V$ on Sebe-Werkzengen rede ich nicht, da die jetrige Göttinger Sternwarte, durch die Huld Sr. Majestät des Königs, wo wohl mit einem fürtreflichen 10füßigen Herschelschen Spiegel Teleskope, als auch durch die Acquisition der Lilienthaler Werkzzeuge, hinlänglich versehen seyn dürtte. An katoptrischen Werkezengen könnte vielmehr Ueberfluß seyn: dagegen wird die Sternwarte eher einen Mangel an dioptrischen Sebe-Werkzengen haben; ich überlasse es daher denjenigen, welche dieses in der Nähe beurtheilen können, in wie fern ein oder ein Paar Achromaten, etwa mit einem Heliometer oder andern Mikrometern versehen, nöthig seyn dürften.

Kleinere, zu einem vollkommenen astronomischen Apparat unentbehrliche Werkzeuge, als Barometer, Hygrometer, Zähler, Kometensucher, Apparate zur Beobachtung der Pendellänge, künstliche Horizonte, Himmels- und Erdkugeln, können mit geringen Kosten nach und nach angeschaft werden."

Aus dieser lichtvollen und lehrreichen Darstellung der dem jetzigen verfeinerten Zustand der Astronomie, angemessenen wesentlich nöthigen Werkzeuge, lassen sich folgende Regeln herleiten, welche bei der Anlage und innern Einrichtung einer Sternwarte, wenn sie jenen Zwicken entsprechen soll, zum Grunde gelegt werden müssen.

1, Muß eine Sternwarte aus mehreren Abtheilungen bestehen, um die verschiedenen Instrumente in verschiedenen Lagen gebrauchen $\mathrm{zu}$ können.

2, Müssen diese Abtheilungen in einer Fläche neben einander liegen, und nicht über einander, 
wie zu Cassel, Mannheim und auf mehreren Thurmförmigen Sternwarten; weil diese Lage für genaue Beobachtungen ganz zweckwidrig ist.

3, Dürfen von den fixen Instrumenten, nur solche in Einer Abtheilung zusammengestellt werden, welche einen gemeinschaftlichen Meridian-Durchschnitt erfordern: wie z.B. der ganze Kreis und das Passagen-Instrument, oder letzteres mit dem Mauerquadranten. Diese Vereinigung der Instrumente gewährt den grossen Vortheil, daß bei Durchgängen die Antritte in den Fäden beider Instrumente gleich hinter einander beobachtet, und so ein Instrument durch das andere, und eine Beobachtung durch die andere, nach ein und eben derselben Uhr, berichtigt werden können.

4, Bei einer Sternwarte mit welcher zugleich eine Lehranstalt verbunden ist, müssen diejenigen Instrumente mit denen der Astronom die feinen für das astronomische Publikum wichtigen Beobachtungen anstellt, von denjenigen getrennt werden, welche für den Unterricht bestimmt sind. Dieses hat auf die Einrichtung des Gebäudes den grossen Einfluß, daß für diese Zwecke verschiedene, von einander abgesonderte Gemächer, angelegt werden müssen.

5, Der zweckmässige Gebrauch des Aequatoreal-Sektors, womit jeder Punkt des Himmels muß übersehen werden können, erfordert einen möglichst freien Horizont, und eine besondere Vorrichtung seines Obdachs; welches sich, wie das Dach einer holländischen Windmühle muß drehen lassen, um die Weltkörper in jeder Lage verfolgen zu können. Es kann also dieses Instrument nicht in die Reihe der übrigen fixen Instrumente gebrachte werden; sondern es muß dazu ein besonderes kleines Gebäude errichtet, oder, wo ein beschränkter Horizont eine erhöhte Lage des Instruments nöthig macht, über der Mitte der Sternwarte, eine hervorragende Kuppel, angelegt werden.

6, Die fixen Instrumente müssen auf besondere, von dem übrigen Mauerwerk des Gebäudes isolirte Quaderpfeiler gestellt werden. Wird diese Vorsicht nicht gebraucht; und die Pfeiler werden mit dem Mauerwerk des Gebäudes in Verbindung aufgeführt: so ist die natürliche Folge, daß das geringste Senken oder Setzen des Mauerwerks, auf die Pfeiler, und also auch auf die daran befindlichen Instrumente Einfluß hat; und bevor der Fehler entdeckt und gehoben wird, zu falschen Beobachtungen Gelegenheit gibt. Es kann aber diese isolirte Anlage der Pfeiler nur alsdann statt finden, wenn die verschiedenen Abtheilungen für fixe Instrumente in einer Fläche neben einander liegen, und wo diese Fläche nicht auf einem hohen Unterbau ruhet, sondern nur einige Fuß hoch über der Horizontalfläche des natürlichen Bodens erhaben ist. Hieraus folgt

7, Die wichtige Regel, daß der Fußboden einer Sternwarte, so wenig wie möglich von den natürlichen Terrain erhöht angelegt werden muß: denn in eben dem Verhältnis, als das Mauerwerk eines Gebäudes höher wird, verstärkt sich auch die untere Fläche der Grundmauer; folglich müssen bei hohen Unterbauten, die Grundmauern oft eine beträchtliche Breite erhalten, und mit den, für die fixen Instrumente anzulegenden Quaderpfeilern nothwendig zusammentreffen oder in Verbindung kommen. Bei den berühmtesten Sternwarten, als zu Oxford, Greenwich und Seeberg, ist diese Regel befolgt, und in wie fern ihre Brauchbarkeit den Absichten entspreche, das zeigen die wichtigen Beobachtungen, welche daselbst gemacht werden.

8, Die Quaderpfeiler für das PassagenInstrument und Mauerquadranten, müssen oberhalb des Fußbodens eine solche Höhe erhalten, daß die Instrumente so entfernt vom Fußboden dazwischen eingelegt und daran befestigt werden können, daß selbst die Beobachtungen im Zenith, mit keinen Unbequemlichkeiten für den Observator verbunden seyn. Ein gewisses Maaß für die Höhe der Pfeiler, läßt sich nur alsdann festsetzen, wenn die Grösse der Instrumente, oder vielmehr der Fernröhre bestimmt ist. Im Allgemein gilt für die Befestigung der Instrumente die Regel: daß die Seheröhre in senkrechter Richtung, so entfernt vom Fußboden seyn müssen, daß ein Mann mit rückwärts gebogenem Kopfe und kniend, das Auge bequem vor das Seheröhr bringen, und im Zenith beobachten könne. Hiezu werden drei Fuß und einige Zoll erfordert.

9, Da bei allen absoluten Beobachtungen auf den richtigen Gang der astronomischen Uhren alles ankömmt: so dürfen diese nicht auf den freien Fußboden gestellt werden, sondern müssen auf Grundpfeilern ruhen, und oberhalb des Fußbodens, an aufgerichteten Quaderpfeilern ihre Befestigung erhalten; damit sie vor jeder möglichen Erschütterung gesichert seyen.

10, Die Erfahrung lehrt, daß jede Abwechselung von Wärme und Kälte den fixen Instrumenten nachtheilig werde; es dürfen daher die Zimmer worin diese aufgestellt sind, nicht geheizt 
werden. Da aber für den Astronomen, zur Ausdauerung der Kälte in harten Winternächten, ein warmes Zimmer unentbehrlich ist: so muß dieses mit demjenigen, worin die häufigsten absoluten Beobachtungen gemacht werden, so nahe wie möglich in Verbindung stehen.

11, Eben so nachtheilig sind den fixen Instrumenten die Veränderungen, welche man an den, von Bruchsteinen und Sandquadern aufgeführten Gebäuden, bei Uebergängen von Frost zu Thauwetter, wahrnimmt; weil durch das Ausschlagen der Mauerfeuchtigkeiten, die Metalle der Instrumente, und zuweilen auch die Gläser in den Fernröhren, anlaufen. Dieses zu verhüten, müssen die innern Wände der Zimmer mit Holzwerk vertäfelt werden; welches zugleich den grossen Vortheil gewährt, daß die Zimmer im Sommer bei starker Hitze, und im Winter bei heftiger Kälte, nicht so sehr den Einwirkungen der äusseren Luft ausgesetzt sind, sondern sich in einer gemässigten Temperatur erhalten, welches bei feinen Beobachtungen nicht unwichtig ist.

12, Die Fußböden in den Zimmern der fixen Instrumente müssen aus einem starken Estrichguß bestehen, deren Oberfläche genau nach der Wasserwage abgeschliffen seyn muß. Fußböden von Eichen oder Tannenbohlen zu ebener Erde, schwinden von den Erdfeuchtigkeiten, wenn sie auch noch so sorgfältig mit trocknem Sand und Kohlenstaub unterlegt sind; durch das Schwinden aber, entstehen Unebenheiten, welche nicht nur dem Observator läßtig, sondern auch der Stellung und Bewegung mancher Geräthe, hinderlich werden. Nicht besser sind die mit Steinplatten belegten Fußböden: denn diese werden nicht selten durch heftigen Frost in die Höhe gezogen; und bei veränderter Witterung erfolgt kein so gleichmässiges Zurückziehen, daß der Boden in einer genau wagerechten Fläche bliebe. Wenn ich nicht irre, so hat der Freyherr von Zach in der Seeberger Sternwarte, zuerst Dielen Fußböden in den Zimmern der fixen Instrumente gehabt; aber aus jenen Ursachen wieder wegnehmen, und durch Gypsböden, ersetzen lassen. Diese Fußböden müssen mit wollenen Teppigen belegt werden, um jedes Geräusch, welches durchs Gehen, oder Umstellen der beweglichen Werkzeuge entstehen kann, zu entfernen, damit die Pendelschläge der Uhren jeden Augenblick gehört werden können.

13, Das Dach einer Sternwarte muß so flach wie möglich angelegt werden; um auf demselben bei Windstillen Wetter, mit kleinen beweglichen
Instrumenten, nach allen Weltgegenden frei beobachten zu können. Besonders wichtig ist das flache Dach, wenn eine Trigonometrische Landesvermessung unternommen werden soll; welche nothwendig von der Sternwarte durch Beobachtungen der terrestrischen Winkel und des Azimuths ausgehen muß. Auch wegen der zweckmässigen Anlage der Durchschnittsklappen, ist ein flaches Dach wesentlich nothwendig; weil diese Klappen bei einem hohen Dache zu schwehr, und das Oeffnen und Verschliessen derselben, zu lästig werden würde.

14, Eine jede Sternwarte, vorzüglich aber eine akademische, muß mit einem freien und etwas erhöheten Platz umgeben seyn, um darauf mit beweglichen Instrumenten, freie Beobachtungen anstellen zu können. Bei Sonnen- und Mondfinsternissen, pflegt es immer eine Menge Liebhaber zu geben, die eine solche Erscheinung durch astronomische Fernröhre zu beobachten wünschen; auch zu andern Zeiten kommen wohl zahlreiche Gesellschaften, um den gestirnten Himmel zu mustern, wozu, so wie zur Prüfung langer Fernröhre und zu detachirten Beobachtungen, ein geräumiger Platz um die Sternwarte, sehr erwünscht ist. Der Herr Justizrath Schröter sagt: „Es gibt noch andere Rücksichten, die bei der Anlage einer neuen Sternwarte, es der Klugheit gebieten, auf einen freien Raum um das Gebäude, Bedacht zu nehmen. Denn wer bürgt uns dafür, daß scharfsinnige Erfindungskraft, nicht noch astronomische Werkzenge bervorbringen wird, die unsere Nachkommen eben so unentbehrlich halten werden, als wir die uns jezt bekannten halten? Werkzeuge, die wahrscheinlich nicht in den Gemächern der jetzigen aufgestellt werden können, sondern eigene Bauvorrichtungen erfordern." Dazu muß also Platz vorhanden seyn, und zwar für diesem Zweck an der Ost- und Westseite, für obige Zwecke aber, an der Südseite.

15, In den Bemerkungen des Herrn Justizraths Schröter heist es:

„wenn eine Sternwarte ganz ibren Zweck erfüllen, und nicht blos des Nahmens, oder der Zierde wegen dastehen soll, so muß mit der seIben die Wobnung des Observators, entweder in unmittelbare Verbindung gesetzt, oder doch derselben so nabe angelegt seyn, daß es nur wenige Augenblicke bedarf, um aus der Wohnung in die Sternwarte kommen zu können. Dieses ist, nach den Urtheilen aller ächten Kenner, ein so wesentliches Bedürfniß, daß es gerathener seyn würde, den Bau der Sternwarte selbst, als die Miterbaunng einer solchen Wohnung zu unterlassen. Wenn der Beobachter auch noch so viel Neigung und Ge- 
schicklichkeit zum Beobachten hat, so kann er doch obne sie, nur wenig, und oft gar nichts vollständiges leisten: denn es treten bei Tage und des Nacbts unzäblbare Fälle ein, da der Beobachter augenblicklich seine übrigen $G e-$ schäfte unterbrechen, und zu den Instrumenten eilen muß; und wenn dieses nicht mit bäuslicher Bequemlicbkeit geschehen kann, so geht manche Beobacbtung verlobren. Bei einer akademischen Sternwarte, macht die Lehranstalt nur einen sebr geringen Theil von dem aus, was geschehen muß; man erwartet von ibr originelle gute Beobachtungen, und bei einer, an Instrumenten so vorzüglich reichen Sternwarte, wie die Göttinger werden wird, siehet ganz Europa dergleichen mannigfaltigenBeobachtungen entgegen. Diese können aber nur alsdann geleistet werden wenn die Wohnung des Direktors, in unmittelbarer Verbindung mit der Sternwarte stebt.

Nach der jetzigen verfeinerten Astronomie, gibt es aber Beobachtungswerkzeuge, und der mannigfaltigen Beobachtungen so viele, daß der Direktor der Sternwarte, unmöglich alles allein, bestreiten kann, sondern ein Gebülfe wesentlich notwendig ist. In Wien, Prag und bei mehrern akademischen Sternwarten, die nicht den dritten Theil so viele Werkzenge haben, als die Göttinger besitzt, sind zwei Beobachter angesetzt; und der Erfolg ist, daß etwas geschiehet, was bei andern Sternwarten nicht gescheben kann."

Es muß also die Wohnung des Direktors entweder von so geräumigen Umfang gebauet werden, daß darin zugleich ein zweiter Observator die nöthigen Bequemlichkeiten finde, oder wenn dieses des Lokale oder anderer Rücksichten wegen, nicht ausführbar seyn sollte, eine besondere Wohnung für diesem Zweck errichtet werden.

Dieses sind die allgemeinen Grundsätze, welche bei der Anlage und innern Einrichtung einer Sternwarte, die alle astronomische und andern Zwecke erfüllen soll, zum Leitfaden dienen.

Die architektonischen Regeln, die bei den Entwürfen einer Sternwarte in Betracht kommen, weichen im Allgemeinen von den, für jedes andere Gebäude zu einem bestimmten Zweck, in

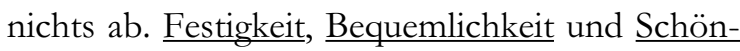
heit, sind die Haupteigenschaften eines jeden öffentlichen Gebäudes, und diese müssen sich besonders bei einer Sternwarte vereinigen.

Festigkeit muß jedes Gebäude haben: aber eine Sternwarte muß diese Eigenschaft in einem so hohen Grade besitzen, als nicht leicht bei einem andern Bau nöthig ist; weil hier ein geringes Senken einzelner Theile oder des Ganzen, nicht den nachtheiligen Einfluß auf den Zweck des Gebäudes äussert, als bei einer Sternwarte. Diesen Grad von Festigkeit zu erreichen, erfordert in der Ausführung des Baues, um so mehr die größte Vorsicht und Aufmerksamkeit, da dieses Gebäude in seinen Umfassungsmauern und der Bedachung, keinen Zusammenhang erhält, sondern an mehrern Stellen getrennt wird. Diesen Zusammenhang, welcher für die Festigkeit eines Gebäudes so äusserst wichtig ist, verliehrt eine Sternwarte dadurch, daß in den, für absolute Beobachtungen bestimmten Zimmern, sowohl in den südlichen als nördlichen Umfassungsmauern, Meridian-Einschnitte angelegt werden müssen, welche sich auch durch das Dach erstrecken; wodurch denn alle Verbindung des Ganzen aufgehoben wird. Wenn diese Trennung der Festigkeit des Gebäudes nicht zum Nachtheil gereichen soll: so muß bei der innern Einrichtung das Hauptaugenmerk dahin gerichtet werden, daß, wenn mehrere Zimmer für fixe Instrumente nöthig sind, diese nicht unmittelbar neben einander, sondern in möglichst größten Entfernungen angelegt werden; damit die Durchschnitte nicht nahe zusammentreffen.

Bequemlichkeit, welche durch die den Absichten entsprechende gute Anordnung der verschiedenen inneren Theile erhalten wird, ist einer Sternwarte eben so wesentlich nothwendig, als jeden andern Gebäude. Diese Eigenschaft wird durch genaue Befolgung obiger Grundregeln, in der Hauptsache erreicht; für einzelne Gegenstände aber, bleibt noch einiges zu bestimmen übrig, wohin vorzüglich folgendes gehört:

1, Die Anordnung der Thüren am Äussern und Innern des Gebäudes. Es erfordert nicht blos der Zweck, sondern auch die Bequemlichkeit, daß die für die beweglichen Instrumente bestimmten Zimmer, wenigstens nach Süden, Hauptthüren erhalten, um mit den Instrumenten nahe vor, oder in den geöfneten Thüren, Beobachtungen anstellen zu können. In dieser Rücksicht, müssen die Thüren eine beträchtliche, jedoch gegen das Ganze, verhältnismässige Breite und Höhe erhalten; wovon erstere zwischen 5 bis $7 \mathrm{Fuß}$, und letztere zwischen 13 und $16 \mathrm{Fuß}$, betragen kann.

Wenn detachirte Beobachtungen angestellt werden sollen, so müssen die Instrumente durch diese Thüren auf den Observations-Platz gebracht werden: folglich muß dieser mit den Fußböden der Zimmer, in einer Horizontalfläche liegen; weil im entgegengesetzten Fall das Ausund Einbringen der Instrumente, mit vielen Un- 
bequemlichkeiten vergesellschaftet seyn würde.

Bei Anordnung der inneren Thüren ist dahin zu sehen, daß sie der zweckmässigen Stellung der Instrumente nicht hinderlich seyn, und daß sie, wo möglich, in Einer Linie liegen. Ihre Breite muß der Breite der äussern Thüren gleich seyn; damit die beweglichen Instrumente bequem aus einem Zimmer in das andere gebracht werden können: ihre Höhe aber, wird nach der Breite in dem Verhältniß wie 2 zu 3 bestimmt. Eben dieses Verhältniß kann auch bei den HauptEingangsthüren in den mittleren Theil der Sternwarte, Anwendung finden; weil diese nicht dazu geeignet sind, Beobachtungen durch dieselben anzustellen.

2, Die Einrichtung der Fenster und Wetterladen. In die Zimmer der fixen Instrumente, gehören auch einige bewegliche Sehewerkzeuge zu detachirten Beobachtungen welche durch die Fensteröffnungen angestellt werden. Dieses setzt aber eine freie Durchsicht voraus; und diese zu erhalten, ist es wesentlich nothwendig, daß die Fensterrähme mit Leichtigkeit ganz weggeschafft werden können. Bei gewissen Beobachtungen am Tage, müssen die Zimmer der fixen Instrumente zum Theil, und oft ganz, verfinstert werden; und dazu sind Blend- oder Wetterladen nöthig, womit das Licht, nach den jedesmaligen Bedürfnissen, gestimmt werden kann. Diese Laden müssen sich eben so leicht, wie die Fenster, entfernen lassen, welches aufs vollkommste dadurch erreicht wird, daß sowohl Laden als Fenster in ihrer halben Höhe getheilt, und nach Art der so genannten englischen Fenster, mit Gegengewichten versehen, und hinter die vertiefte und verkleidete Brüstungsmauer, versenkt werden.

Um das Licht noch mehr in seiner Gewalt zu haben, sind auch Vorhänge nöthig; die jedoch durchsichtig seyn, und daher aus weisser Leinewand oder Flanell bestehen müssen.

3, Nach dem Vorhergehenden, werden in den Zimmern so wohl der fixen als der beweglichen Instrumente, durch die Thür- und Fensteröffnungen, Beobachtungen gemacht: folglich ist die Höhe der Thüren und Fenster nicht willkürlich, sondern muß sich nach der Polhöhe jedes Orts richten; um mit einem, nahe vor die Oeffnung gebrachten Instrument, die Höhe jedes Planeten, $\mathrm{zu}$ jeder Jahreszeit, und in allen Lagen, erreichen zu können. Göttingens Polhöhe ist 51 Grad 32 Minuten; es müssen also zur Erreichung jenes Zwecks, die Thür- und Fensteröffnungen, vom Fußboden des Zimmers angerechnet, eine Höhe von 14 bis 15 Fuß erhalten. Diese Thür- und Fensterhöhen, geben zugleich den Maasstab für die Höhe des Gebäudes, welche, in architektonischen Rücksichten, mindestens 20 Fuß betragen muß. Für diese Höhe stimmt auch der Freyherr von Zach aus folgenden astronomischen Gründen:

"Je mehr die Meridian-Einschnitte in den Zimmerdecken entfernt bleiben, desto weniger wird der durch die Oeffnung einströmende Wind, die Instrumente erreichen und in Bewegung setzen können. Auch aus einem optischen Grunde ist es rathsam, die Objektive von diesen Oeffnungen zu entfernen: denn je grösser diese Entfernung ist, desto deutlicher wird man bei Tage die himmlischen Körper sehen und scharf beobacbten können. Ich glaube daber daß eine Höbe von 20 Fuß, unumgänglich nöthig sey. "

4, Die Meridian-Einschnitte durch die Mauern und das Dach, müssen theils mit geraden theils mit schrägen Thüren und Klappen gegen das Einwirken der Witterung verschlossen werden; und das Oeffnen derselben muß nicht nur mit Bequemlichkeit, sondern auch in der möglichst kürzesten Zeit geschehen können.

$\mathrm{Zu}$ den obern Theil der Kuppel muß eine bequeme Trepppe führen, deren Breite nicht unter 3 Fuß 6 Zoll, und die Stuffenhöhe nicht über 8 Zoll betragen darf.

Eine Sternwarte mit den oben bemerkten Eigenschaften der Festigkeit und Bequemlichkeit, muß auch auf die Sinne einen angenehmen Eindruck machen; und dieses wird durch die Schönheit erreicht.

Von den allgemeinen Regeln über die Schönheit der Gebäude, will ich nur diejenigen zum Grunde legen, welche bei einer Sternwarte, die auf Architektur, und einen ihr entsprechenden Charakter einigen Anspruch machen soll, nicht dürfen aus der Acht gelassen werden.

Schon im ersten Abschnitt sind die astronomischen Gründe angegeben, warum eine Sternwarte nicht in einem Thal, sondern auf einer Anhöhe gebauet werden muß. Hier kömmt dieser Gegenstand in architektonischen Rücksichten aufs neue in Betrachtung. Daß eine den Zwecken des Gebäudes angemessene Lage, grossen Eindruck auf unsere Sinne macht, und daß ein erhöht liegendes Gebäude, die Blicke der Vorübergehenden weit mehr auf sich zieht, als ein niedrig liegendes, wird wohl Niemand zu leugnen wagen. Es ist also eine Anhöhe der schicklichste Ort für ein Gebäude, das Sensation machen soll: vorzüglich schicklich aber für eine Sternwarte mit welcher immer der Begriff 


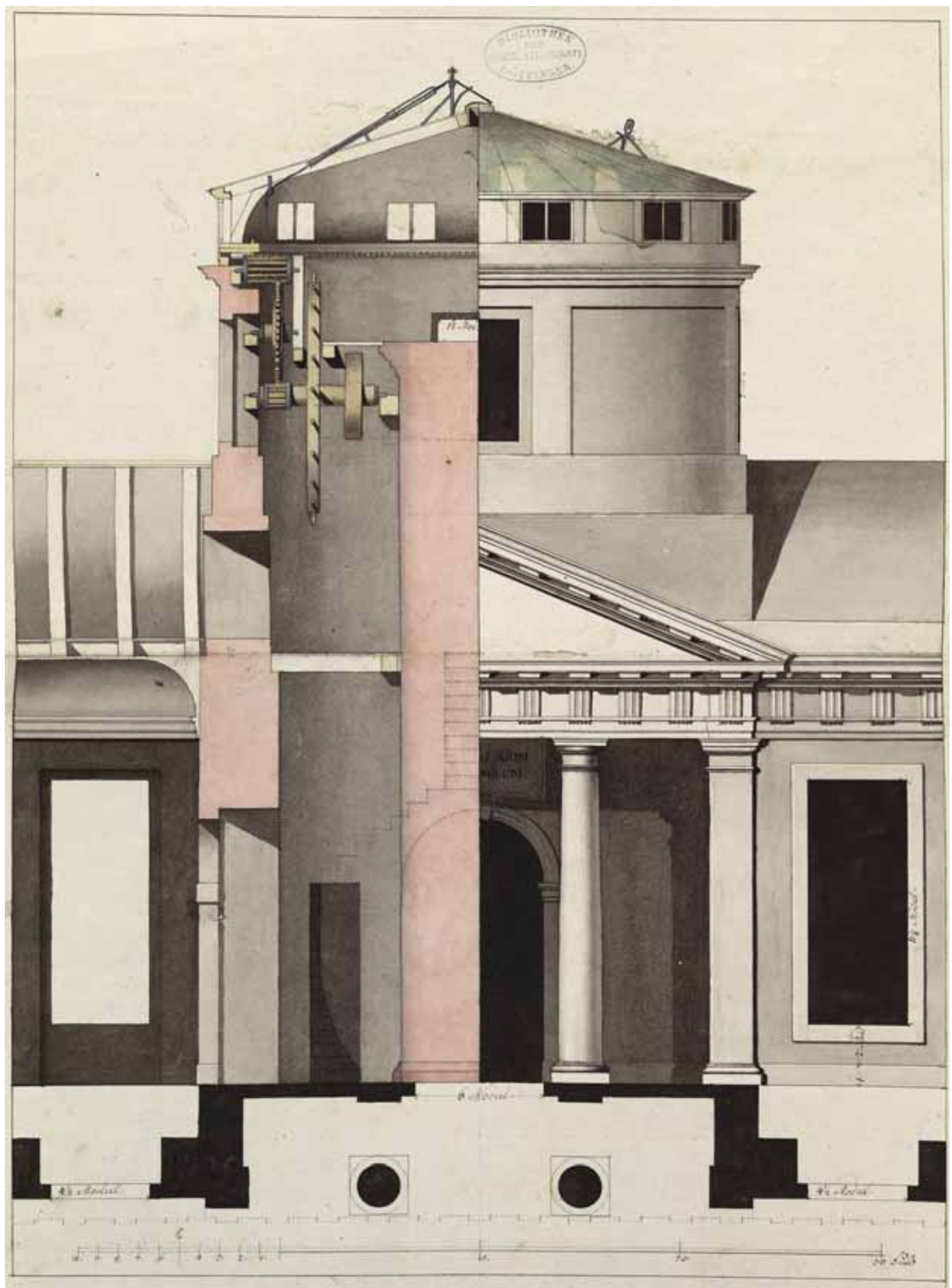

Abb. 26: Teil des Entwurfs von 1802, der den Querschnitt durch den Zentralteil der Sternwarte mit Details der Mechanik für die damals neuartige Drehkuppel zeigt. Die mechanische Funktion wurde von Borheck nicht beschrieben und sollte vermutlich während des Baues weiterentwickelt werden. Müllers später realisierte Kuppelkonstruktion war bekanntlich mangelhaft und eine funktionsfähige Drehkuppel erhielt die Sternwarte erst beim Umbau 1887/88. Die zentrale Säule in der Eingangshalle, die das Gewicht des Fernrohres erschütterungsfrei aufnehmen sollte, wurde noch von Borheck zugunsten eines Gewölbes über der Eingangshalle aufgegeben, auf das sich die Fernrohrmontierung abstützt. Dies erlaubte eine repräsentativere Gestaltung der Halle. 


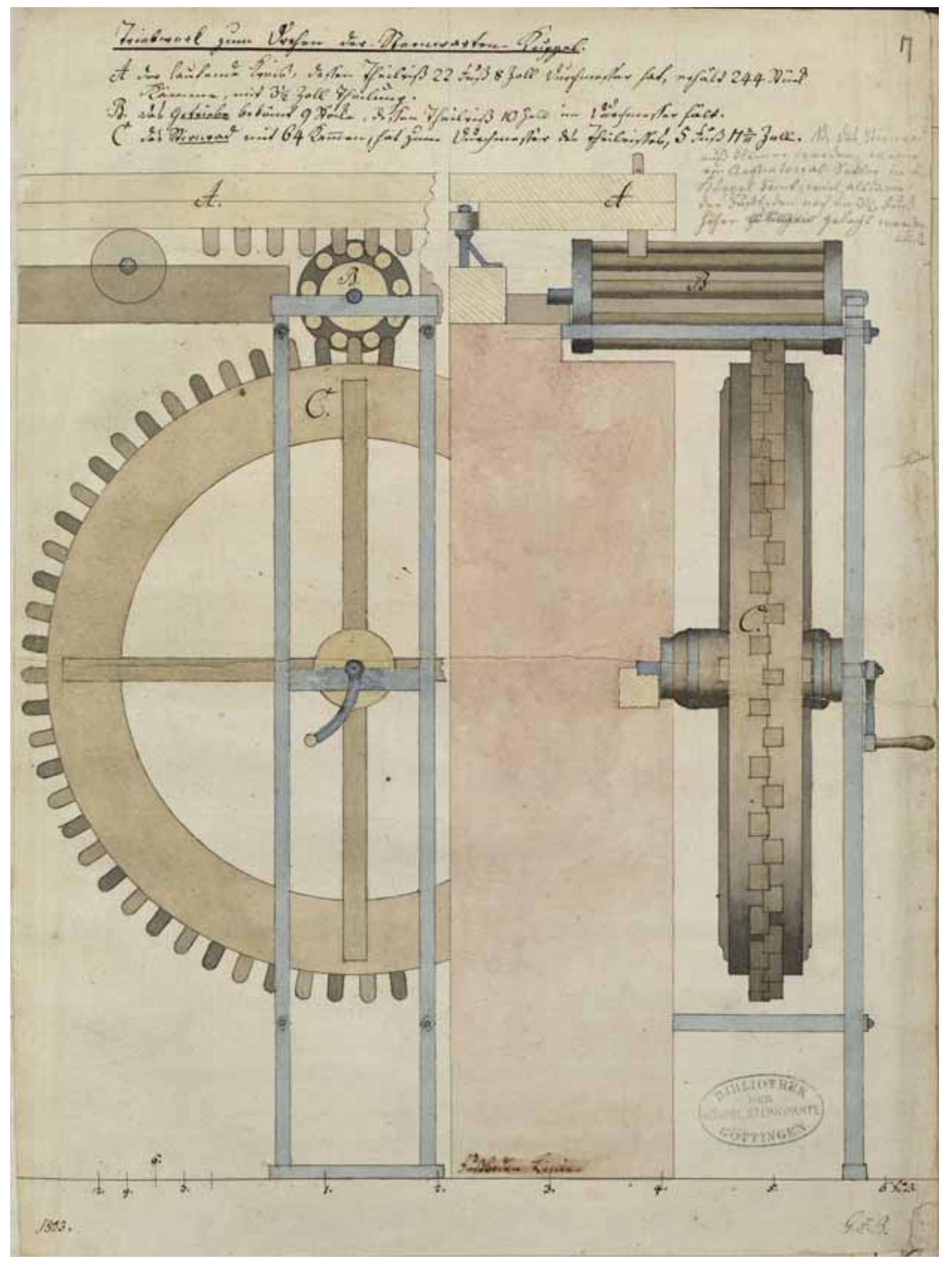

Abb. 27: Detailzeichnung des Triebwerks zum Drehen der Kuppel von 1803. Die rechts oben eingefügte Nachschrift Borhecks lautet: NB. Das Stirnrad (gemeint ist Rad C) muß kleiner werden, wenn ein Aequatoreal-Sektor in die Kuppel kömt; weil alsdann der Fußboden noch um 311/2Fuß höher gelegt werden muß. Die Funktionsfähigkeit ist schwer einzuschätzen, denn sie zeigt eine Handkurbel, mit der sich das Triebwerk schwerlich in Bewegung setzen ließe. Abb. 26 dagegen zeigt eine notwendige Untersetzung sowie ein großes mit Handgriffen versehenes Rad, mit dem man die Kuppel vermutlich hätte drehen können. Auch Repsolds Kuppel von 1887/88 enthält eine eisernes „Steuerrad““ zum Drehen der Kuppel, das funktionsfähig ist, aber das nicht benutzt werden darf, weil damit die Blitzableiter der Kuppel beschädigt würden. Die Kuppel war 1945 undicht geworden und wurde zugeschweißt. 
einer weiten unbeschränkten Aussicht verbunden ist. Je höher also eine Sternwarte gestellt werden könnte, je grösser müsste der Eindruck seyn, den sie auf unsere Gefühle machte; aber eine solche Lage läßt sich nicht immer mit den Zwecken vereinbaren, wovon die Gründe im ersten Abschnitt angegeben sind. Indessen macht ein freistehendes Gebäude, auch ohne auf einer beträchtlichen Anhöhe zu stehen, immer einen gefälligen Eindruck, wenn nur nicht ein zu beschränkter Raum, dasselbe umgibt.

Jedes öffentliche Gebäude, muß einen seiner Bestimmung angemessenen Charakter haben. So muß z.B. eine Kirche ein feierliches Ansehen erhalten: ein Pallast, und vorzüglich die Wohnung des Landesfürsten, muß einen Eindruck von Würde und Grösse machen; ein Prachtgebäude muß Pracht und Reichthum zeigen; ein Zeughaus und Stadtthor männlichen Ernst; ein Gefängniß, so wie ein Zuchthaus muß Schauder erregen; und ein Wohnhaus, so wie ein Landhaus, muß ein gefälliges und angenehmes Ansehen haben. Es gibt also eben so viel verschiedene Charaktere, als es verschiedene Arten der Gebäude gibt (Zeichnungen aus der schönen Baukunst von Dr. Stieglitz).

Aber welchen Charakter muß eine Sternwarte haben? Diese Frage finde ich nirgends beantwortet; ich glaube aber daß ein edler fester Charakter, der auf die Einbildungskraft wirkt, und Stoff zum Nachdenken gibt, der Bestimmung dieses Gebäudes am angemessensten seyn dürfte.

Symmetrie und Eurhytmie im Ganzen so wie in den einzelnen Theilen des Gebäudes, machen immer einen edlen Eindruck; und dieser kann durch zweckmäßige Anwendung einer Säulenordnung, noch erhöhet werden. Da indessen hier nur von einer besonderen Gebäudeart die Rede ist; so würde es überflüssig seyn, mehr über diesen Gegenstand zu sagen. Ich gehe also zur Erläuterung der Entwürfe über, bei denen die im Vorhergehenden bemerkten Regeln und Eigenschaften, zum Grunde liegen.

Nicht leicht kömmt es bei der innern Einrichtung eines Gebäudes auf eine so äuserst pünktliche Erfüllung der Zwecke an, als bei einer Sternwarte. Hier müssen alle Abtheilungen nicht nur sehr genau den Bedürfnissen angemessen seyn, sondern auch so neben einander gestellt werden, daß sie bei ihrer Benutzung alle Vortheile und Bequemlichkeiten darbieten. Dieses fordert man aber von jedem anderen Gebäude auch; allein man wird dabei doch immer weit mehr freien Spiel- raum haben, und dem einen Zimmer etwas an Grösse zulegen, und den andern abnehmen können. Dieses findet hier aber nicht Statt; denn jedes fixe Instrument erhält seinen bestimmten Platz; der wegen der Meridianurchschnitte, auch nicht um einen halben Zoll verändert werden darf. Es müssen also die Grössen der Zimmer, genau nach den darin aufzustellenden Instrumenten und übrigen zum Beobachten erforderlichen Bedürfnissen, ausgemittelt werden.

Das erste Augenmerk bei dem Entwurf dieses Gebäudes Taf. I, muß auf den mittleren Theil gerichtet werden: weil sich dieser von den übrigen durch eine Kuppel auszeichnen soll, worin ein fixes Instrument einen zweckmäßigen Standpunkt finden kann. Da aber, ausser diesem fixen Werkzeuge noch ein bewegliches zum Aufsuchen der zu beobachtenden Gegenstände, so wie eine Uhr, ein Schreibpult und ein Paar Stühle, Platz haben müssen; und überdies der Treppenaustritt und die Vorrichtung zum Drehen des Kuppeldachs, den Raum beengen: so darf die innere Weite oder der Durchmesser der Kuppel, nicht weniger als $20 \mathrm{Fu} \beta$ betragen. Im gegenwärtigen Fall sind $22 \mathrm{Fuß}$ für den inneren - und durch Zusetzung zweier Mauerdicken, 26 Fuß für den äussern Durchmesser angenommen worden.

Dieses Maaß ist die Grundlage zur Grösse des mittleren Theils. Da aber der Kuppelmauer mit Recht der Fehler einer Schwäche würde vorgeworfen werden, wenn man sie nach diesern äussern Durchmesser von dem Fußboden des Eintritts an, ohne alles Mauerrecht aufführen wollte: so müssen jenen $26 \mathrm{Fuß}$, noch auf jeder Seite 8 bis 9 Zoll, zur Verstärkung der Mauer, zugesetzt werden.

Nach dem Lokale dieser Sternwarte, würde dem mittlern Theil zur Rechten, das Zimmer angelegt werden müssen, worin die zum Unterricht bestimmten fixen Instrumente aufgestellt werden. Diese bestehen aus einem kleinen Passagen-Instrument, und einern südlichen und nördlichen Mauerquadranten: Das Passagen-Instrument bekömmt den vortheilhaftesten Stand genau in der Mitte des Zimmers, wie durch die beiden Quaderpfeiler $A-B$ angegeben ist, deren Entfernung von einander, nach der Länge der Axe bestimmt werden muß. Für dieses Instrument, und für die beiden Mauerquadranten $\mathrm{C}$ und $\mathrm{D}$, wird ein gemeinschaftlicher Meridian-Durchschnitt durch die Umfassungsmauern bei $a$ und $b$ angelegt, dessen Weite, in Rücksicht der drei Durchsichtslinien, 12 Zoll betragen muß. Diesen Durchschnitten werden die Qua- 
derpfeiler der Mauerquadranten so nahe gebracht, als es die isolirte Lage der Grundpfeiler von den Grundmauern des Gebäudes, verstattet.

Nach der Grösse des hiesigen Mauerquadranten von 6 englischen Fuß, muß jeder Quaderpfeiler oberhalb des Fußbodens, 7 Fuß 6 Zoll Länge, 3 Fuß Dicke und 10 Fuß Höhe erhalten. Bei ihrer Stellung ist zu bemerken, daß sie dem Observator zur Rechten stehen; weil es nur wenige Menschen gibt, die mit dem linken Auge durch die Fernröhre beobachten.

Die Richtung derselben gegen die Einschnitte, muß nach dem Durchmesser des Fernrohrs, und den Abstand der Gradfläche von dem Pfeiler, bestimmt werden. Bei den hiesigen Quadranten, hat das Fernrohr sehr nahe 3 Zoll Durchmesser, und die Gradfläche steht 4 Zoll von den Quaderpfeiler ab. Nach diesen Maassen muß jeder Pfeiler zwei Zoll hinter die Durchschnittsöffnung zurücktreten, um von derselben durch das Fernrohr nur so viel zu bedecken, als die freie Durchsicht erfordert; damit für das PassagenInstrument eine völlig freie Durchsicht bleibe.

Die Uhr E dient so wohl bei Beobachtungen mit dem Passagen-Instrument an dem südlichenund nördlichen Himmel, als auch mit dem südlichen Mauerquadranten. Sie muß daher einen solchen Standpunkt haben, daß sie von dem Observator bei jeden dieser Fälle übersehen werden kann. Deutlicher ist die Lage dieser Verschiedenen Werkzeuge auf Taf. III - Fig. 1 - nach einem grösseren Maasstaabe vorgestellt; wo sie mit gleichen Buchstaben bezeichnet, und auch die verschiedenen Gesichtslinien angegeben sind, wonach der Stand der Uhr in E bestimmt werden muß.

Nach dieser festgesetzten Stellung der Instrumente, und bei der Nothwendigkeit, daß auf allen Seiten derselben für mehrere Personen, welche in dem Gebrauch dieser Werkzeuge unterrichtet werden, so wie für einige bewegliche Instrumente und andere Bedürfnisse, Raum vorhanden seyn muß; und daß, theils zur Erleuchtung des Zimmers, theils zu detachirten Beobachtungen, auf jeder Seite des MeridianDurchschnitts, ein Fenster wesentlich nöthig ist, läßt sich leicht ermessen, daß diese Gemach nicht weniger als $20 \mathrm{Fuß}$ Breite und 33 bis $34 \mathrm{Fuß}$ Tiefe im Lichten, erhalten dürfe.
Unmittelbar mit diesen Zimmer muß ein zweites für die grösseren beweglichen Instrumente in Verbindung stehen; dessen Breite von jenem zwar verschieden, aber doch nicht viel geringer seyn kann. Dieses Zimmer F muß nach Süden eine doppelflüglichte Thür von mindestens $6 \mathrm{Fuß}$ Breite erhalten; um durch diese die Instrumente auf die südliche Terrasse fahren zu können. In der östlichen Seite werden zwei Fenster angelegt, durch welche detachirte Beobachtungen gemacht werden; wenn bei windigem Wetter die Instrumente nicht auf die Terrasse gebracht werden dürfen.

So wie auf der rechten Seite des mittlern Theils, die beiden Abtheilungen für den Unterricht angelegt sind, so sind auf der andern Seite zwei gleich große Zimmer zu den feinen Beobachtungen erforderlich. In dem Zimmer G, welches für einen Bordaischen Kreis und ein grosses Passagen-Instrument bestimmt ist, wird durch die Mitte ein Meridian-Durchschnitt $c-d$ von 12 Zoll Breite nöthig. Zunächst dem südlichen Einschnitt C, wird der runde Quaderpfeiler $\mathrm{H}$ von 8 Fuß im Durchmesser, zum Standpunkt des ganzen Kreises angelegt. Hinter diesen kommen die beiden Quaderpfeiler J für das Passagen-Instrument, und seitwärts, dem Observator zur Rechten, die Uhr K; deren Lage so bestimmt wird, daß sie den Beobachter, wenn er den Kopf seitwärts beugt, im Auge stehe. Da aber auch, bei Umdrehung des Seherohrs nach Norden, so wie bei Beobachtungen mit dem Bordaischen Kreise - wenn dafür nicht eine besondere Uhr aufgestellt wird - die Uhr ins Gesicht fallen muß: so muß nach diesen verschiedenen Rücksichten der Stand der Uhr ausgemittelt und so gerichtet werden, wie in $\mathrm{K}$ das Passagen-Instrument in F, kann noch ein beweglicher Quadrant oder ein Geotheodolit in die Mittagsfläche gestellt, und daselbst gebraucht werden. Der übrige Raum dieses Zimmers, dient $\mathrm{zu}$ den oben specificirten kostbaren kleineren Werkzeugen, die nicht in den der Lehranstalt gewidmeten Gemächer aufbewahrt werden dürfen; und an den Wänden können Glasschränke für die astronomische Bibliothek angebracht werden.

In die Abtheilung $L$ kommen diejenigen beweglichen Instrumente, deren sich der Direktor der Sternwarte zu den feinern Beobachtungen bedient. Bei nicht so reich dotirten Sternwarten,

Abb. 28: Tafel I. Grundriss des zweiten Entwurfs Borhecks, der für die Erstellung des Fundaments der Sternwarte benutzt wurde und die tatsächliche spätere Raumaufteilung weitgehend korrekt wiedergibt. In der Bauausführung durch Müller wurde die Anordnung der Innen- und Außentreppen sowie einige Wände in den Wohntrakten geändert. Dieser Grundriss wird in zweiten Abschnitt des Manuskripts (S. 76 ff) ausführlich beschrieben. 
[Bild nur Stand,. DINA3 Klappseite eineziehen

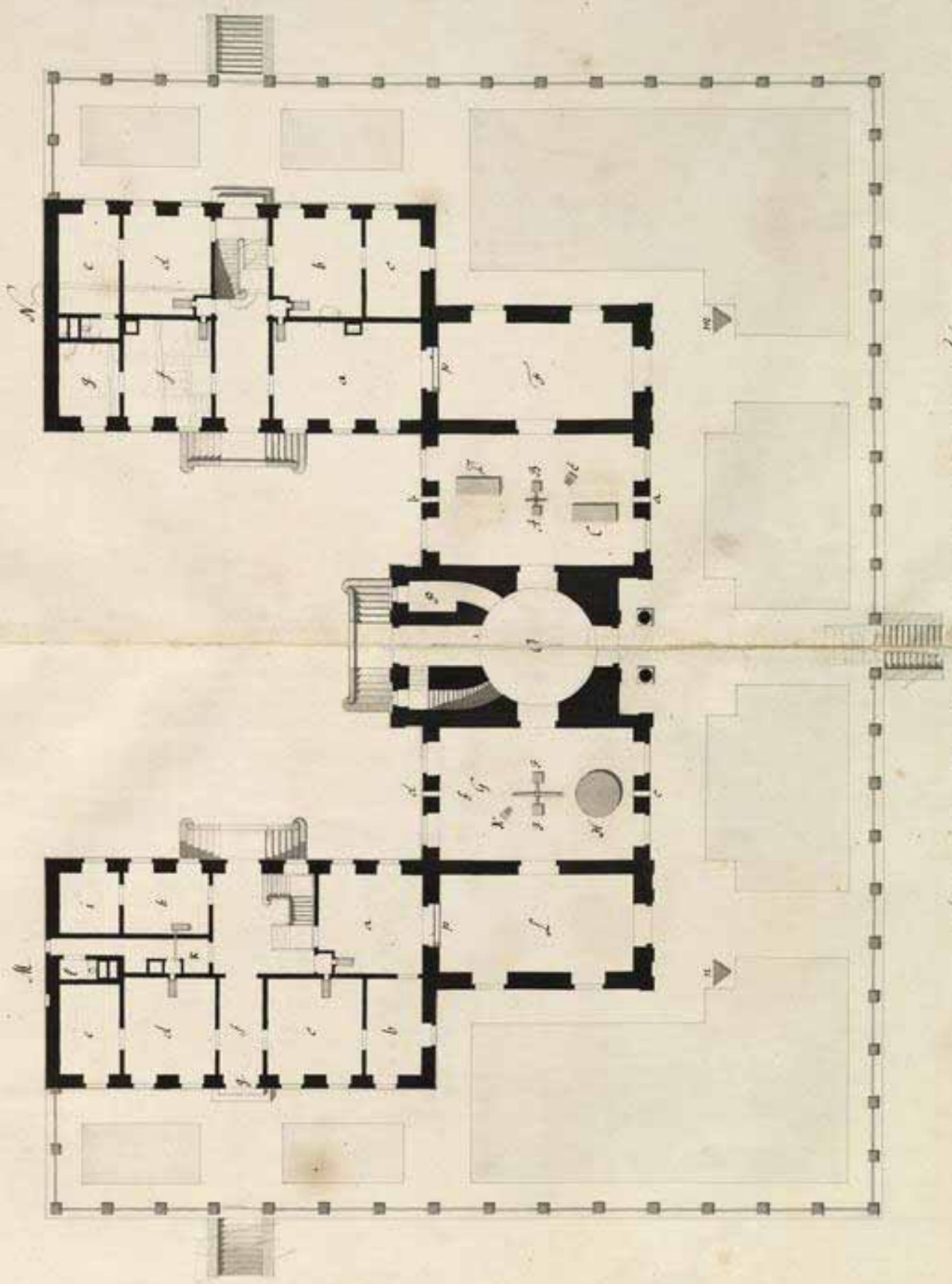



oder da, wo mit derselben die Wohnung des Astronomen nicht unmittelbar in Verbindung gesetzt werden kann, brauchte dieses Zimmer nicht so groß zu seyn, sondern es könnte davon ein Schreibkabinet abgenommen werden, welches mit einen Ofen versehen werden müßte. Dieses Kabinet würde alsdann mit den Zimmer $G$ durch eine besondere Thür in unmittelbare Verbindung gesetzt, so daß der Observator in harten Winternächten jede Beobachtung mit Gemächlichkeit abwarten könnte. Weit zweckmässiger ist es aber, wenn die Wohnungen der Observatoren, mit der Sternwarte vereinigt sind, wie hier durch die beiden Flügel $\mathrm{M}$ und $\mathrm{N}$ geschehen ist.

Der westliche Flügel $\mathrm{M}$ ist zur Wohnung des Direktors bestimmt, dessen Studierstube a, mit der Sternwarte in unmittelbarer Verbindung steht; folglich kann er jeden Augenblick zu den Instrumenten kommen. Neben der Studierstube ist eine Kammer b, und an dieser ein Besuchszimmer C. Auf der andern Seite ist die Wohnung d und Schlafkammer e. Zwischen dem Besuchzimmer und der Wohnstube, ist ein Vorzimmer $f$ welches in $g$ eine Glasthür hat, die zur Terrasse führt. Die Stube h und Kammer i, ist für das Gesinde bestimmt; und hinter diesen Zimmern liegt ein Gang k, der zum Einheitzwinkel dient, und zum Abtritt I führt. Die Küche, Speisekammer und Keller, faßt das Souterrain, und eine Stube und Kammer für erwachsene Kinder, so wie Wäsch- und Vorrathskammern finden sich in der Halbetage; folglich hat dieser Flügel alle Bequemlichkeiten, die einer vollkommenen Haushaltung wesentlich sind.

In dem östlichen Flügel $\mathrm{N}$ liegt unmittelbar an der Sternwarte, der theoretische Lehrsaal a. Hinter demselben ist eine Stube $b$ und Kammer $\mathbf{c}$ für den zweiten Observator. Wenn man annehmen dürfte, daß der zweite Beobachter immer ein unverheiratheter Mann sey, so würde derselbe mit zwei Stuben und Kammern, und eine Wohnung für den Aufwärter ausreichen können: aber diese Voraussetzung würde gegen das Interesse dieser wichtigen Anstalt seyn, weil sie manchen geschickten Mann zurückhalten würde, eine Stelle anzunehmen, die ihn, der eingeschränkten Wohnung wegen, von den Genuß häuslicher Freuden ausschlösse. Es ist daher der Klugheit gemäß, die Wohnung des zweiten Beobachters so einzurichten, daß sie für eine Familie zureiche.

Demnach würde die Stube $d$ und Kammer e für die Hausfrau, und die Stube nebst Kammer $\mathrm{f}$ - $\mathrm{g}$, für das Gesinde bestimmt werden. Ein Besuchzimmer und einige Kammern, so wie eine Stube und Kammer für den Observatorienwärter, würden die Halbetage ausfüllen, und im Souterrain findet sich nicht nur der nöthige Raum zur Küche, Speisekammer und Keller, sondern auch für ein Waschhaus zum Gebrauch beider Familien.

Diese ganze Anlage umgibt eine Terrasse, deren Breite nach der West-, Süd- und Ostseite, $40 \mathrm{Fuß}$, und ihre Höhe von den natürlichen Boden an gerechnet, $6 \mathrm{Fu}$ beträgt. Die äuseren Grenzen sind mit Quaderdocken besetzt, welche durch eiserne Stäbe mit einander vereinigt sind, und ein Brustgeländer bilden. $\mathrm{Zu}$ dieser Terrasseführt eine Freitreppe, die auf die Mitte der Sternwarte gerichtet ist. ${ }^{1}$

$\mathrm{Zu}$ freien Beobachtungen mit parallaktischen Instrumenten dienen die dreieckigten Quaderpfeiler $m$ und $n$, auf welche die Instrumente gleich so aufgestellt werden können, daß sie in ihre richtige Lage kommen. Die Entfernung dieser Pfeiler von dem Gebäude, muß so viel betragen, daß die darauf stehenden Instrumente die grösste amplitudo ortiva und occidua beherrschen; demnach dient der Pfeiler $\mathrm{m}$ für den südöstlichen - und der Pfeiler $\mathrm{n}$ für den südwestlichen Himmel.

So viel im Allgemeinen über die Anlage und innere Einrichtung einer Sternwarte, die mit der Lehranstalt zugleich die Vervollkommnung und Erweiterung der Wissenschaft, vereinigen soll. Jetzt sind noch die speciellen architektonischen Verhältnisse zwischen den verschiedenen Abtheilungen, auszumitteln übrig, damit das Äussere des Gebäudes seiner Bestimmung entsprechend werde. Zur Erreichung dieses Zwecks, soll hiebei die dorische Säulenordnung zum Grunde gelegt werden, weil diese dazu geeignet ist, einem Gebäude nicht nur ein dauerhaftes, sondern auch ein edles Ansehen zu geben.

Es sind schon oben die Gründe angeführt, warum eine Sternwarte nicht unter 20 Fuß Höhe im Lichten erhalten dürfe; um also jenen Forderungen Genüge zu leisten, sollen für die äussere Gebäudehöhe $22 \mathrm{Fuß}$ angenommen werden. Aus dieser festgesetzten Höhe ergibt sich der Maßstab oder der Model, nach welchem so wohl der Grund als Aufriß des Gebäudes, entworfen werden muß.

Bekanntlich wird die Höhe einer dorischen Säule ohne Säulenstuhl, in 20 Theile getheilt,

\footnotetext{
1 Redaktion: Streichungen im Text zeigen, zeigen, dass - wie auf
} Taf. I erkennbar - zunächst drei Freitreppen geplant waren. 
wovon das Gebälke vier Theile, und die Säule mit Fuß und Kapitäl 16 Theile erhält. Ein solcher Theil ist der Model, welcher nach Werkmaaß 13 Zoll und eine Kleinigkeit mehr beträgt.

Nach diesem Modelmaaß, bekömmt der mittlere Theil, worauf die Kuppel ruhet, 25 1/3 Model; jede zunächst liegende Abtheilung 21 1/3 und jedes Eckzimmer 20 2/3; also beträgt die Länge des Gebäudes überhaupt 109 1/3 Model, oder nach Werkmaaß gerechnet, 118 Fuß 5 1/3 Zoll.

Die Tiefe des Gebäudes kann wegen bequemer Stellung der fixen - und beweglichen Instrumente, besonders in den zur Lehranstalt bestimmten Zimmer nicht geringer als 37 Model angenommen werden, welches nach Werkmaaß $40 \mathrm{Fuß} 1$ Zoll beträgt.

Für dieses 22 Fuß hohe Gebäude, darf die Mauerdicke, in Rücksicht der hiesigen Bruchsteine, nicht unter $3 \mathrm{Fuß}$ angenommen werden. Demnach erhält jedes Eckzimmer $34 \mathrm{Fuß}$, und jedes der für die fixen Instrumente bestimmten Zimmer, deren äussere Mauern um 3 Zoll zurücktreten, $33 \mathrm{Fuß} 6$ Zoll Tiefe im Lichten.

Der mittlere Theil des Gebäudes, bildet beim Eintritt von der Südseite, einem runden Vorplatz $\mathrm{C}$, aus welchem man in die angränzenden Zimmer der fixen Instrumente, so wie zu dem Kabinet gelangt. Um so wohl den nöthigen Raum für die Treppe, als auch einen bequemen Zugang nach den obern Kuppelzimmer zu gewinnen, muß die nördliche Seite des mittlern Theils, einen Vorsprung von 4 2/3 Modell erhalten.

Zur Erleuchtung der Treppe auf der einen und des Kabinets $P$ auf der andern Seite, dienen die, neben der Hauptthür angelegten schmalen Fenster, deren Breite 2 1/4 Model beträgt. Die übrigen Fenster erhalten 4 1/2 Model, und die Haupt- und inneren Thüren 5 2/3 Model zur Breite im Lichten.

Bei der Lage der Kuppel über der Mitte des Gebäudes, würde die südliche Mauer eine unverhältnißmässige Dicke erhalten, wenn man sie bis an die vordere Linie vortreten liesse. Diese Unzweckmässigkeit wird dadurch vermieden, wenn man die Mauer nicht weiter vorspringen läßt, als es die Grösse der Kuppel erfordert, und den freien Raum, von der vordern Gebäudelinie, bis an die eben bestimmte Gränze, in eine Säulenlaube verwandelt. Dadurch erhält das Gebäude nicht nur eine grosse Zierde, sondern es wird auch der ihm eigenthümliche Charakter schärfer bezeichnet, wie aus dem Aufriß Taf. II - A, deutlich in die Augen fällt; zu dessen Erläuterung ich jetzt übergehe.
So bald ein Gebäude nach einer gewissen Säulenordnung gebauet werden soll, und der Model derselben festgesetzt so ist, auch die Höhe des Gebäudes bis an das Dach, in den einzelnen horizontalen Abtheilungen, ganz genau bestimmt. Bei der dorischen Ordnung bekömmt der Säulenfuß einem Model, der Säulenschaft 13 1/2, das Kapitäl 1 1/2, der Unterbalken Einem, der Fries 1 1/3, und das Kranzgesims $12 / 3$ Model zur Höhe.

Die Gründe, warum dieses Gebäude ein plattes Dach erhalten muß, sind bereits oben angegeben. Es müssen aber doch die Dachflächen eine geringe Neigung zum Abzug des Regens haben; und da unter gewissen Umständen auf dem Dache Beobachtungen angestellt werden sollen: so muß noch ein besonderer horizontaler Dielenboden über das Dach gelegt werden, um bequem darauf gehen, und die Instrumente sicher aufstellen zu können. Um diese wesentliche Vorrichtung dem äusseren Anblick zu entziehen, und zugleich eine Brustwehr um das Dach zu erhalten, wird ein Geländer oder eine Ballustrade nothwendig, deren Höhe 4 Model betragen muß. Durch diese Anordnung gewinnt das Gebäude nicht nur an seiner scheinbaren Höhe ausserordentlich, sondern sein Charakter wird auch dadurch genauer bestimmt, indem es den Laien hinter der Ballustrade etwas vermuthen läßt, was ihm zum Nachdenken Gelegenheit gibt.

Um auf dem Dache eine möglichst freie Communikation zu haben, ist über der Säulenlaube kein Fronton angeordnet. Dadurch ist zugleich der Vortheil erreicht, daß in der Untersatzmauer der Kuppel, eine zum Dach führende Thür, nach Süden, angelegt werden kann; welches im entgegengesetzten Fall, entweder an der Ost- oder Westseite geschehen müßte, die aber wegen der Dachfläche, nicht so bequem aus fallen könnte. Der nördliche Vorsprung, worin zum Theil die Kuppel treppe liegt, muß ein Fronton erhalten; für dessen senkrechte Dachhöhe der fünfte Theil der Gesimslänge, zwischen den beiden Ausladungspunkten, angenommen ist.

Die Brüstung der Fenster ist, vom Fußboden der Zimmer an gerechnet, 3 Model hoch: und die Fensterhöhe, in dem Verhältniß wie 2 zu 5 beträgt 11 1/4 Model, oder 12 Fuß 2 Zoll Werkmaaß. Nach der, der dorischen Ordnung eigenthümlichen Regel, sollte die Höhe der Fenster zur Breite, sich wie 2 zu 1 verhalten; allein hier wird diese vermehrte Höhe wesentlich nothwendig, um mit den Instrumenten, aus den Fenster 


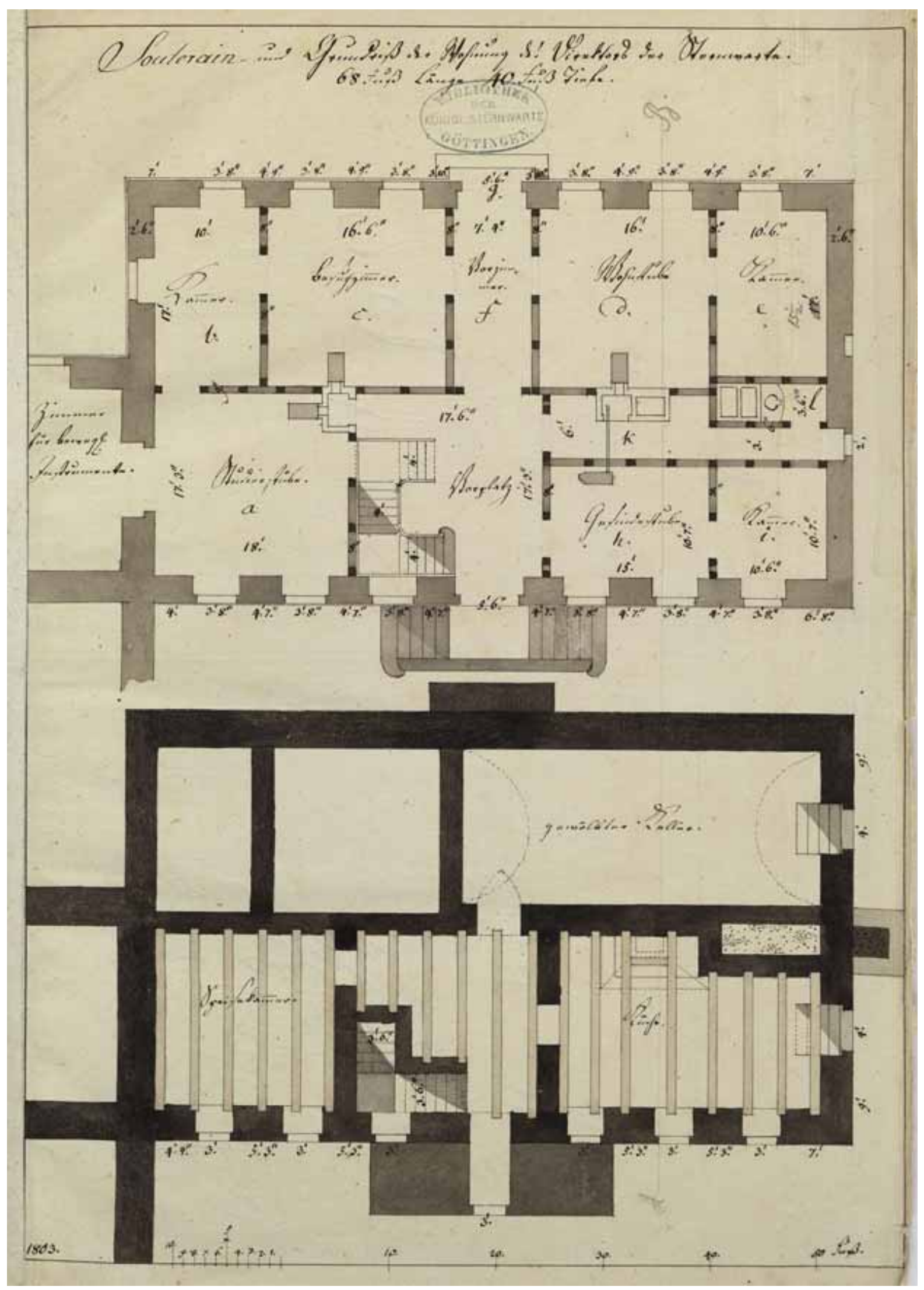

Abb. 29: Souterrain und Erdgeschoss des Westflügels der Sternwarte. Küche und Speisekammer sind im Souterrain untergebracht, eine Waschküche im Souterrain des Ostflügels. Das Erdgeschoss des Westflügels war die Wohnung der Familie Gauß. Links unten im Uhrzeigersinn beginnend findet man die Studierstube von Gauß, eine Kammer, das Besuchszimmer (Sterbezimmer von Gauß), ein Vorzimmer (Flur), die Wohnstube der Familie Gauß, eine Kammer, die Kammer und Stube für das Gesinde und den Vorplatz mit Treppenaufgang ins Obergeschoss. Zu den beim Bau erfolgten Änderungen gegenüber diesem Entwurf siehe die Fußnote auf S. 39. 
öffnungen, hoch genug am Himmel, beobachten zu können.

Die äusseren Thüren der beiden Eckzimmer, müssen eben so hoch als die Fenster herauf gehen; folglich erhalten diese eine Höhe von 14 1/4 Model oder 15 Fuß 5 Zoll im Lichten. Das_Verhältniß dieser Thüren, deren Breite 6 Fuß 1 2/3 Zoll beträgt, kann man eben so wenig, wie das der Fenster, unter die schönen rechnen; weil sie gegen ihre Breite etwas zu hoch sind; allein der Zweck muß dieses geringe Mißverhältniß rechtfertigen. Eine ganz andere Bewandniß hat es mit der mittleren Hauptthür. Diese ist nicht, wie jene, dazu bestimmt, in derselben mit beweglichen Instrumenten Beobachtungen anzustellen, sondern dient blos zum Eingang in das Gebäude. Es bedarf daher diese keine so beträchtliche Höhe, sondern kann in ihren geraden Gewänden, in dem Verhältniß wie 2 zu 3 angelegt werden. Diese mindere Höhe läßt oberhalb der Thür, noch ein freies Feld übrig; welches sehr zweckmässig zu einer Inscriptionstafel genutzt werden kann.

Die Meridian-Durchschnitte ${ }_{2}$ müssen von der inneren Fußbodenfläche an gerechnet, in einer Höhe von 5 Fuß, ihren Anfang nehmen; damit das Auge des Beobachters die freie Durchsicht in horizontaler Richtung habe. Diese Durchschnitte gehen in einer Breite von 12 Zoll, loth- und winkelrecht durch die Mauern, so wie durch die Bedachung, und werden gegen Wind und Wetter, durch Thüren und Klappen geschützt.

Der äussere viereckigte Umfang der Kuppelmauer, geht in dieser Form bis zur Höhe des hintern Frontondachs, und bildet den Untersatz der Kuppel. Auf diesem Untersatz fängt die Rundung der Kuppelmauer an, und bekömmt zunächst eine zwei Fuß hohe Plinte. Die Höhe der Hauptmauer steht mit dem Durchmesser in dem Verhältniß wie 1 zu 3, welches nach Werkmaaß 8 Fuß 8 Zoll beträgt. Ein 12 Zoll hohes Kranzgesims begränzt diese Mauer, und auf denselben nimt das bewegliche Kuppeldach seinen Anfang, welches 10 Fuß senkrechte Höhe hat; folglich keine vollkomne Halbkugel bildet.

Die Fenster in der Kuppelmauer sind nach den vier Weltgegenden gerichtet, und gewähren den Vortheil, daß durch selbige mit kleinen beweglichen Instrumenten Beobachtungen gemacht, und Gegenstände für das Hauptinstrument aufgesucht werden können. Da aber bei Sternbeobachtungen am Tage, das, durch diese Fenster einfallende Licht, dem Beobachter nachtheilig werden würde, so müssen Laden und Vorhänge angebracht werden, um das Seitenlicht abzuhalten; weil durch die geöffnete Durchschnittsklappe in dem beweglichen Kuppeldache, Licht genug einfällt.

Der Meridian-Durchschnitt des Kuppeldachs, geht nicht, wie in den untern Zimmern der fixen Instrumente, vom südlichen Horizont bis zum nördlichen, sondern nur vom ersteren bis zum Zenith; weil durch das Drehen des Dachs, die Durchschnittsöffnung in jede Lage gebracht werden kann.

Die westliche Ansicht der Sternwarte, und die damit in Verbindung stehende Wohnung des Direktors, nebst der vorliegenden Terrasse, ist in B dargestellt.

Die äussere Façade der Wohnung hat bei ihrer Simplicität doch etwas gefälliges, und deutet auf einen Bewohner, der nicht im Geräusch und grossen Verhältnissen, sondern in einer gewissen häuslichen Zufriedenheit lebt, und seine Zeit den Wissenschaften widmet. Dieser Eindruck würde noch verstärkt worden seyn, wenn dem ersten Stockwerk eine etwas grössere Fensterhöhe hätte können gegeben werden; allein dieses war bei der angenommenen Regel das Mauerwerk der Wohnung nicht höher, als das der Sternwarte aufzuführen, unmöglich, wenn anders die Halb-Etage auch noch nutzbar werden sollte. Bei den jetzigen Verhältnissen, hat das untere Stockwerk 10 Fuß 6 Zoll, und die HalbEtage 8 Fuß 6 Zoll Höhe im Lichten; und die Fenster des ersten sind $6 \mathrm{Fu}$ und die des letzten 3 Fuß 6 Zoll hoch.

Die Fußböden der untern Zimmer in der Wohnung, liegen mit der oberen Zockenlinie gleich: in der Sternwarte aber, liegen sie um, die Zockenhöhe niedriger; folglich müssen aus dem Studierzimmer des Direktors, und aus dem theoretischen Lehrsaale, zwei Stuffen zu den Eckzimmern angelegt werden, wie solches auch im Grundriß Taf. I, in den Communikationsthüren in $p$ angegeben ist.

Damit bei Beobachtungen auf dem Sternwartendache, die freie Aussicht nicht zu sehr beschränkt wird: so ist zur senkrechten Dachhöhe der Wohnungen nur der vierte Theil von der Tiefe des Gebäudes angenommen; welches auch um so füglicher geschehen kann, da diese Dächer, der Dauer und Zierde wegen, mit Schiefersteinen gedekt seyn müssen. Diese geringe Dachhöhe verstattet nicht, die zum Haushalt nöthigen Wäsch- und Vorräthekammern in dem Bodenraum anzubringen; und das ist die Ursache, warum selbige in die Halb-Etage verlegt sind. 
[Bild nur Stand, DINA3 Faltseite einziehen]

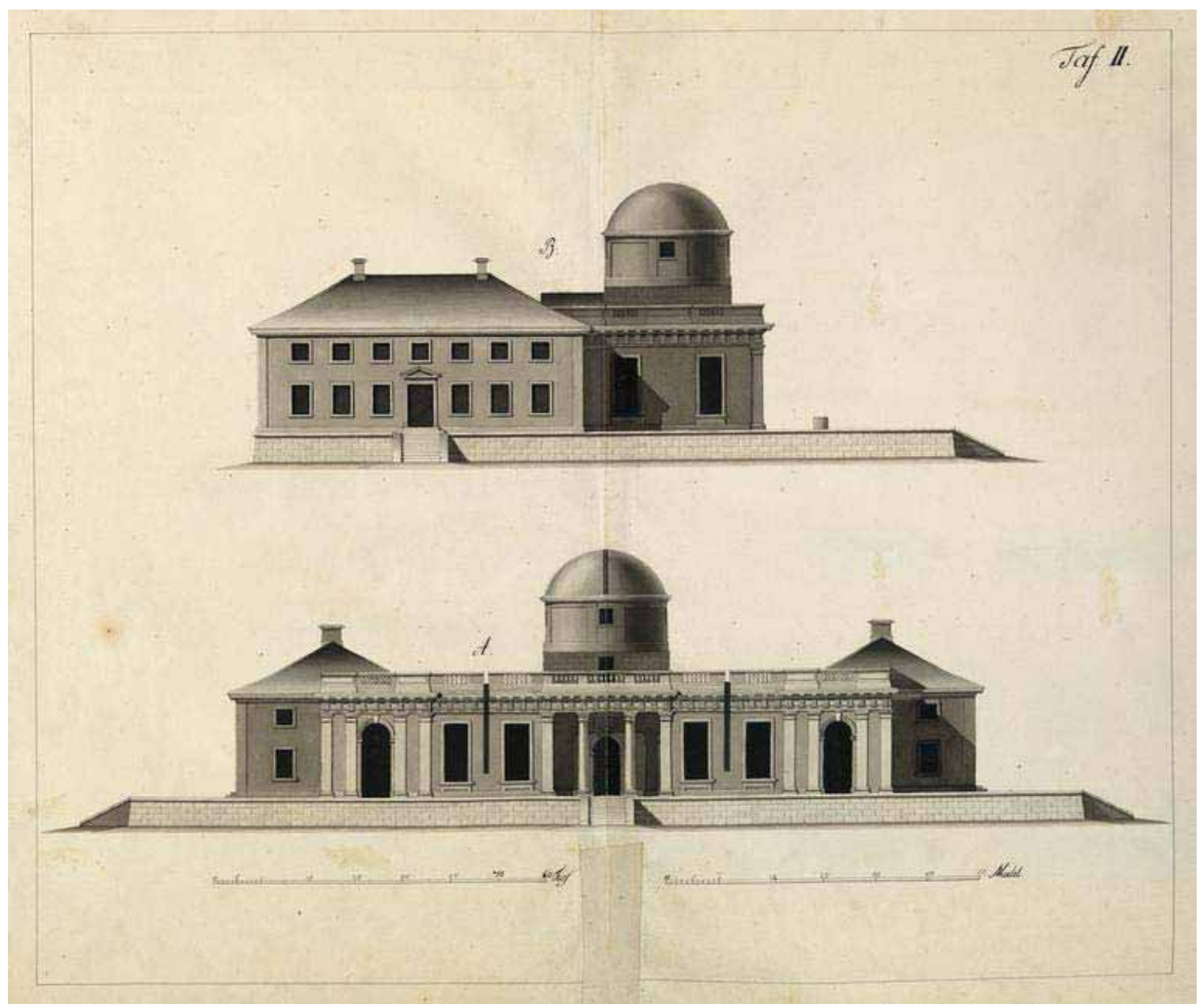




\section{Dritter Abschnitt}

\author{
Über die Ausführung des Baues
}

Es ist eine bekannte Regel, daß die genaue Untersuchung des Grundes, der Ausführung des Baues vorangehen müsse, um nach Beschaffenheit der mehr oder mindern Festigkeit des Bodens, beurtheilen zu können, wie tief und in welcher Stärke, die Grundmauern angelegt werden müssen. Die Festigkeit, als die Haupteigenschaft eines Gebäudes, beruhet lediglich auf einem dauerhaften Grunde; und jeder dabei begangene Fehler, der entweder durch einen nicht ganz erreichten festen Boden, oder durch fehlerhafte Aufführung der Grundmauern entsteht, wird dem Gebäude nachtheilig. Besonders wichtig ist der Grundbau bei einer Sternwarte, und es muß, so wohl bei Beurtheilung des Bodens, als bei Aufführung des Mauerwerks, weit mehr Vorsicht angewendet werden, als bei jedem andern Gebäude. Die Regeln welche bei Behandlung der verschiedenen Baugründe befolgt werden müssen, sind jedem Baumeister bekannt; ich gehe also zur Beschreibung des Grundbaues über, so wie er bei diesem Gebäude wirklich ausgeführt ist.

Der für diese grosse Anlage angekaufte Platz, war von jeher als Gemüsegarten genutzt; folglich bestand die Oberfläche aus einer Lage recht guter Dammerde, die aber doch nur zwei Fuß dick war. Unter dieser Dammerde, fand sich eine 4 Fuß tiefe Lage mit Sand vermischten Lehm, so wie man ihn zu Mauerarbeiten bei Feuermauern gern gebraucht. Darauf folgte eine 8 Fuß tiefe Lage recht fest zusammenhängender Kiesgrund, der nicht anders als mit Spitzhacken konnte losgehauen werden. Unter diesem stand ein eisenschüssiger Thonmergel, der eben die Festigkeit hatte, und auf 20 Fuß T'iefe von ein und eben derselben Beschaffenheit war. Alsdann kam weisser Triebsand etwa zwei Fuß tief, und unter diesem öffnete sich eine sehr reichhaltige Wasserquelle.

Dieses sind die verschiedenen Lagen des Grundes, welche sich auf der Baustelle bei Grabung eines Brunnens fanden. Daß nun auf einem solchen, von Natur so äusserst festen Boden, jedes, selbst das grösste Lastgebäude, sicher gegründet und aufgeführt werden könne, wird kein Kunstverständiger in Zweifel ziehen. Wenn die Dammund Lehmlage ausgegraben, und auf den festen Kiesboden die Grundmauern angelegt werden, so ist ein Zusammendrücken des Bodens, durch die aufgesetzte Last, undenkbar; und es kann bei einer sorgfältigen Wahl der Materialien, und regelmässigen Aufführung der Grundmauern, gar kein anderes Senken oder Setzen eintreten, als was man von jedem, aus Bruchsteinen bestehenden Mauerwerk, erwartet, ohne davon den geringsten Nachtheil für das Gebäude befürchten zu dürfen. Wäre der, unter der Dammerde befindliche Lehmboden, mehr bindend gewesen, so hätte diese Lehmlage nicht einmal bis auf den Kiesboden, sondern nur zwei bis höchstens drei Fuß tief dürfen ausgegraben werden: aber wegen dieser sandigen Lehmart, und bei der Wichtigkeit des Gebäudes, ist die Lehmlage ganz, und die obere Fläche der Kiesschicht ausgeworfen worden; wodurch denn der Grundgraben an der Westseite, wo das Terrain am niedrigsten war, $7 \mathrm{Fu} ß$ und an der Ostseite, als dem höchsten Punkt, 8 Fuß Tiefe erhielt, um das Fundament genau wagrecht zu legen. Bei dieser Tiefe des Grundes, mußte die Grundmauer in zwei Absätzen aufgeführt werden, davon dem untern $4 \mathrm{Fu}$, und dem obern $3 \mathrm{Fu} \beta$ Höhe gegeben sind.

Der, dieses Gebäude umgebende Observationsplatz oder Terrasse mußte nach den hiesigen Lokale, 6 Fuß von dem natürlichen Boden erhöht, angelegt, folglich auch der Untersatz des Gebäudes, zu $6 \mathrm{Fu}$ hoch, angenommen werden.

Nach dieser Höhenbestimmung der Grundund Untersatzmauern, und nach der, schon oben angenommenen Stärke der Hauptmauer zu 3 Fuß, ist die Dicke der Grund- und Untersatzmauern auf folgende Art festgesetzt und ausgeführt worden.

Bei der Beschaffenheit der hiesigen Bruchsteine, ob sie gleich größtentheils lagerhaft sind, muß bei jedem Absatz oder Grundband, 4 Zoll zum Mauerrecht angenommen werden. Demnach würde der obere Absatz des Untersatzes 3 Fuß 8 Zoll Dicke erhalten.

$\mathrm{Da}$ aber an den vorspringenden Eckzimmern, die Wandpfeiler 3 Zoll vor der Hauptmauer, und die Pfeilerfüsse, noch um 4 Zoll weiter vortreten: so ist das Mauerrecht nach der äussern Seite, zu 8 Zoll angenommen worden; folglich erhält dieser obere Satz 4 Fuß Dicke. Jedem der drei folgenden Absätze, sind auf beiden Seiten 4 Zoll 


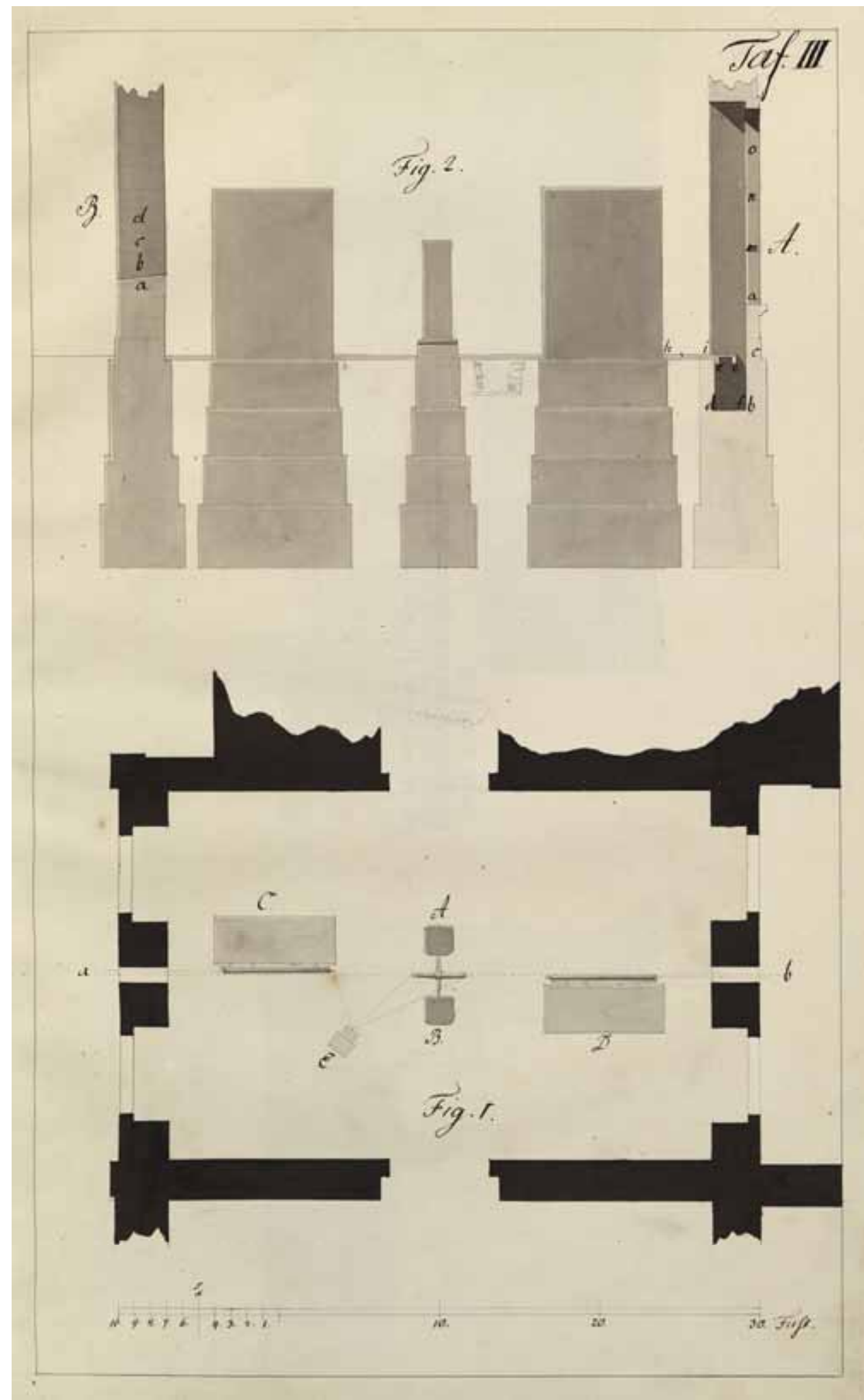

Abb. 31 Tafel III. Detailzeichnung zur Fundamentierung der Säulen, auf denen das Passageinstrument $(\mathbf{A}-\mathbf{B})$ und an denen die beiden vorgesehenen Mauerquadranten (C und D) so montiert sind, dass mit dem rechten Auge beobachtet werden kann (vgl. Text S. 76 und den älteren Grundriß in Abb. 22 mit der spiegelbildlichen Anordnung). Die Trennung der Fundamente von den Mauern des Gebäudes war eine der wesentlichen Neuerungen des Borheckschen Entwurfes gegenüber früheren Sternwartenbauten. Die alte Göttinger Sternwarte auf einem Turm der Stadtmauer wurde u.a. deshalb aufgegeben, weil die mangelhafte Statik exakte Beobachtungen sehr erschwerte. 
Mauerrecht gegeben; Wodurch der untere Grundband 6 Fuß Breite bekommen hat.

An der östlichen und westlichen Giebelseite, wo blos Eckpfeiler angeordnet sind, würde es eine unnütze Verschwendung des Mauerwerks gewesen seyn, wenn man da ebenfalls 8 Zoll Mauerrecht hätte annehmen wollen. Hier sind blos Vorsprünge an den Ecken aufgemauert, und zwischen diesen, so wie bei den, um drei Zoll zurückspringenden Mauern der beiden Zimmer für die fixen Instrumente, beträgt das Mauerrecht 4 Zoll; bei den Scheidemauern aber nur 3 Zoll. Es hat also bei den ersteren der untere Satz der Grundmauern 5 Fuß 8 Zoll, und bei den letzteren $5 \mathrm{Fuß}$ Breite erhalten.

So tief als die Grundmauern der Umfassungswände gelegt sind, eben so tief sind auch die Quaderpfeiler der Mauerquadranten und PassagenInstrumente gegründet, und in eben so viel Absätzen aufgeführt worden, um den Druck der Pfeiler auf eine breite Grundfläche zu vertheilen.

Nach der Grösse des hiesigen Mauerquadranten von 6 englische Schuh, mußte der südliche und nördliche Quaderpfeiler, oberhalb des Fußbodens, 7 Fuß 6 Zoll Breite, 10 Fuß 6 Zoll Höhe, und zur Sicherung seines festen Standes, 3 Fuß Dicke erhalten. Jedem der vier Absätze sind, nach der schmalen Seite, zur Vergrößerung der Grundfläche, 6 Zoll, nach der langen Seite aber, nur 3 Zoll Mauerrecht gegeben. Es ist demnach der obere Grundband jedes Pfeilers, 4 Fuß breit 8 Fuß lang, der zweite 5 Fuß breit 8 Fuß 6 Zoll lang; der dritte 6 Fuß breit 9 Fuß lang, und der vierte oder untere, 7 Fuß breit, 9 Fuß 6 Zoll lang.

Diese Pfeiler, mit den dazwischen errichteten Quaderpfeilern des kleinen Passagen-Instruments sind auf Taf. III im Grundriß Fig. 1, und im Aufriß Fig.2 vorgestellt; wo aus letzteren zugleich ersichtlich wird, daß die Pfeiler der Mauerquadranten den Umfassungsmauern zwar nahe kommen, aber doch mit denselben in keiner Verbindung stehen: folglich die oben gegebene Regel, über den isolirten Stand der fixen Instrumente, genau erfüllt worden ist.

Die beiden Pfeiler, zwischen welchen das Passagen-Instrument eingelegt wird, ruhen auf einem gemeinschaftlichen Fundament aus Qua-

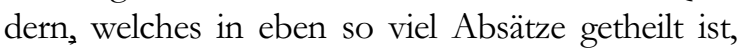
wie die Fundamente zu den Mauerquadranten. Oberhalb des Fußbodens haben diese Pfeiler 7 Fuß Höhe; und damit selbige durch ein zufälliges heftiges Anstossen, gegen Erschütterungen gesichert bleiben, so darf ihre Breite und Dicke nicht unter zwei Fuß betragen. Ihre Entfernung von einander, muß etwas grösser seyn, als die Länge der Axe; damit das Instrument bequem in die Pfannen gelegt, und wieder ausgehoben werden könne, ohne daß die Axe die Pfeiler berühre.

Für das, in dieses Zimmer bestimmte Passagen-Instrument von $3 \mathrm{Fu}$ Brennweite, und 2 Fuß 6 Zoll Axe, ist der obere gemeinschaftliche Grundband 8 Fuß lang, 3 Fuß 8 Zoll breit angelegt worden; und da jedem Absatz, auf allen Seiten 4 Zoll Mauerrecht gegeben sind, so ist der zweite 8 Fuß 8 Zoll lang, 4 Fuß 4 Zoll breit; der dritte 9 Fuß 4 Zoll lang, 5 Fuß breit, und der untere 10 Fuß lang, 5 Fuß 8 Zoll breit .

Die untern Grundbände dieser drei Pfeiler, haben jeder 4 Fuß Höhe, und bestehen aus drei Lagen Quaderstücken; von dene die untern 12 Zoll, und die beiden folgenden jede 18 Zoll hoch sind. Von den drei übrigen Absätzen, hat jeder zwei 18 Zoll hohe Lagen; folglich ist die ganze Höhe bis zum Fußboden, 13 Fuß.

Oberhalb des Fußbodens, ist jeder Mauerquadranten Pfeiler aus sieben Lagen zusammengesetzt; deren jede aus einem Quader von 7 Fuß 6 Zoll Länge, 3 Fuß Breite und 18 Zoll Höhe besteht. Diese Lagen sind ohne allen Mörtel so genau auf einander gefugt, daß die Pfeiler, wie aus einem ganzen Stein bestehend, können angesehen werden.

Diese Anordnung weicht von der gewöhnlichen Meinung der Astronomen ab, welche die Mauerquadranten-Pfeiler, aus einem einzigen Stein errichtet wissen wollen; allein bei einer so sichern Untergründung, auf einem so äuserst festen Boden, wo ein Senken nach der einen oder andern Seite schlechterdings unmöglich ist, finde ich keinen einleuchtenden Grund über die Nothwendigkeit eines einzigen Steins.

Selbst bei einem weniger soliden Grundbau, würde ein, aus mehreren Stücken zusammengesetzter Pfeiler, den aus Einem Stück vorzuziehen seyn; weil bei dem erstern weit leichter eine Correction vorgenommen werden könte, als bei den letztern. Auf der hiesigen alten Sternwarte, besteht die südliche Quadrantmauer aus einem ganzen Stein, und die nördliche ist aus mehrern kleinen Quaderstücken zusammengesetzt. Beide ruhen auf der alten Thurmmauer, deren eine Seite, so gut der Witterung ausgesetzt ist, wie die andere: und gleichwohl ist der südliche ganze Stein, schon vor vielen Jahren aus seiner Lage gewichen; dagegen der nördliche noch ganz genau Loth- und Wagrecht steht. 
In der Sternwarte auf Seeberg, besteht jeder dieser Pfeiler auszwei auf einander gefugten Granit- Blöcken. Diese Steinart ist unstreitig, wegen ihrer Härte und Trockenheit, den Sandsteinquadern weit vorzuziehen: aber man findet sie nicht so häufig, und in hiesiger Gegend gar nicht. Wo also zu diesen, so wie zu den übrigen Pfeilern für fixe Instrumente, Sandsteinquader oberhalb den Fußböden müssen genommen werden, da ist die Vorsicht nöthig, sie einige Jahre zum Austrocknen frei stehen, und dann erst mit gutem Oehlfirniß tränken, und zuletzt, mit einer stark deckenden Oehlfarbe, anstreichen zu lassen. Dadurch wird die, für die Instrumente nachtheilige Einwirkung der Witterung abgehalten; wovon die Quaderpfeiler auf der hiesigen alten Sternwarte den bündigsten Beweis geben.

Die beiden Pfeiler des Passagen-Instruments, haben jeder einen Sockel von 18 Zoll Höhe; wovon 12 Zoll oberhalb, und 6 Zoll unterhalb des Fußbodens treten. Auf diesen stehen die 6 Fuß hohen Pfeiler, welche mit eisernen Döbbeln in die Sockel versetzt sind.

Die Grösse der einzelnen Quader für jede Lage der verschiedenen Grundbänder obiger drei Pfeiler anzugeben, würde zu weitläuftig seyn; ich bemerke also nur, daß so viel wie möglich grosse Werkstücke genommen, und diese sehr genau an und auf einander gefugt, und die nächst folgenden Lagen so geordnet werden müssen, daß eine gute Verbindung erhalten werde. Die hier gebrauchten grösseren Quader, halten 24, 21, 20, 18 , und die kleinsten nicht unter 12 Kubikfuß.

Die Untergründung des Uhrpfeilers besteht, bis zur Höhe des natürlichen Bodens, aus gutem Mauerwerk: aber die übrigen 6 Fuß Höhe, bis zum Fußboden, sind von Quadern aufgeführt; um so wohl dem gerichteten Quaderpfeiler, woran die Uhr befestigt wird, ein sicheres Unterlager zu geben, als auch die, vor dem Pfeiler wesentlich nothwendige Vertiefung von 10 Zoll ins Gevierte, zum Versenken der Uhrgewichte, mit der grössten Genauigkeit anlegen zu können. Die Höhe eines Uhrpfeilers oberhalb des Fußbodens, ist mit Sockel und Hauptgesims 7 Fuß; die breite Seite, an welcher das Uhrgehäuse befestigt wird, beträgt 16 Zoll, und die schmale Seite 12 Zoll.

Die Grundpfeiler des grossen PassagenInstruments in den Zimner $G$ - Taf. I, sind eben so, wie die kleineren, im Zusammenhange und in vier Absätzen, aufgeführt; von welchen der untere 11 Fuß 8 Zoll lang, 5 Fuß 4 Zoll breit, der zweite 11 Fuß lang, 4 Fuß 8 Zoll breit, der dritte 10 Fuß
4 Zoll lang, 4 Fuß breit, und der vierte 9 Fuß 8 Zoll lang, $3 \mathrm{Fuß} 4$ Zoll breit ist. Jeder der beiden Sockel ist $2 \mathrm{Fuß} 8$ Zoll ins Gevierte und $2 \mathrm{Fu}$ hoch, und jeder aus einem Stück bestehende aufgerichtete Pfeiler, hat 8 Fuß Höhe und 2 Fuß 3 Zoll ins Gevierte. Die kleinsten Quader welche zu diesem Grundpfeiler genommen sind, halten 13, die Übrigen aber $16-18-20$ und 24 Kubikfuß.

Der runde Pfeiler $\mathrm{H}$ für den bordaischen Kreis, ist in seinem ganzen Umfange ebenfalls von Quadern in vier Absätzen aufgeführt. Dieser Pfeiler geht nur bis an die Oberfläche des Fußbodens, und bekömmt oberhalb desselben eine Zocke oder Platte; deren Höhe, nach Verhältniß der Höhe des Instruments, bestimmt wird. Zum Durchmesser dieser obern Platte, sind 8 Fuß angenommen, und zum Mauerrecht jedes Absatzes 3 Zoll; folglich ist der untere Grundband $10 \mathrm{Fu} \beta \mathrm{im}$ Durchmesser, und jeder folgende 6 Zoll weniger. An den beiden untern Grundbänden, besteht jede Lage aus 8 Stück Quadern von 2 Fuß 6 Zoll Breite, welche auswendig nach der Rundung behauen, und die Fugenschnitte nach den Mittelpunkt gerichtet sind. An den dritten Grundbande, ist jede Lage aus 6 Stück Quadern zusammengesetzt, und so auch die erste Lage des obern Grundbandes; die zweite aber, worauf die Zocke kömmt, besteht aus einem mittleren Durchbinder von 8 Fuß Länge 3 Fuß Breite, und aus zwei Zirkelstücken, welche an jede Seite des Mittelstücks anschließen.

Auf den Untersatzmauern der Umfassungswände, ist eine Zocke von einem Model, oder 13 Zoll hoch, und zwei Zoll Vorsprung, angeordnet. Dazu sind 18 Zoll hohe Quader genommen: wovon 2 Zoll in die darauf kommende rauhe Mauer zurück gesetzt sind; und die noch übrigen 3 Zoll Höhe, treten nach unterwärts, und sind durch die zur Terrasse aufgebrachte Erde, und inwendig durch die Fußbodendicke gedeckt.

Die Eckstücke zu den Pfeilerfüssen sind 3 Fuß 6 Zoll lang und eben so breit, und 18 Zoll hoch; damit daran der Anlauf noch gearbeitet werden konnte. Unter jeden Wandpfeiler neben den Thüren, sind die Quader, wegen der Thürzocke, 4 Fuß lang 3 Fuß breit. Die Zwischenstücke sind von verschiedener Grösse; jedoch haben die, unter den Fenstern, alle ein bestimmtes Maaß von 11 Zoll Breite und 16 Zoll Höhe; weil hier die in die rauhe Mauer hinauf springende zwei Zoll, wegfallen mußten, indem auf die Zocke eine Tafel gestellt ist, wie die Aufrisse Taf. II zeigen. Die Ursache dieser schmalen Zockenstücke, liegt in 


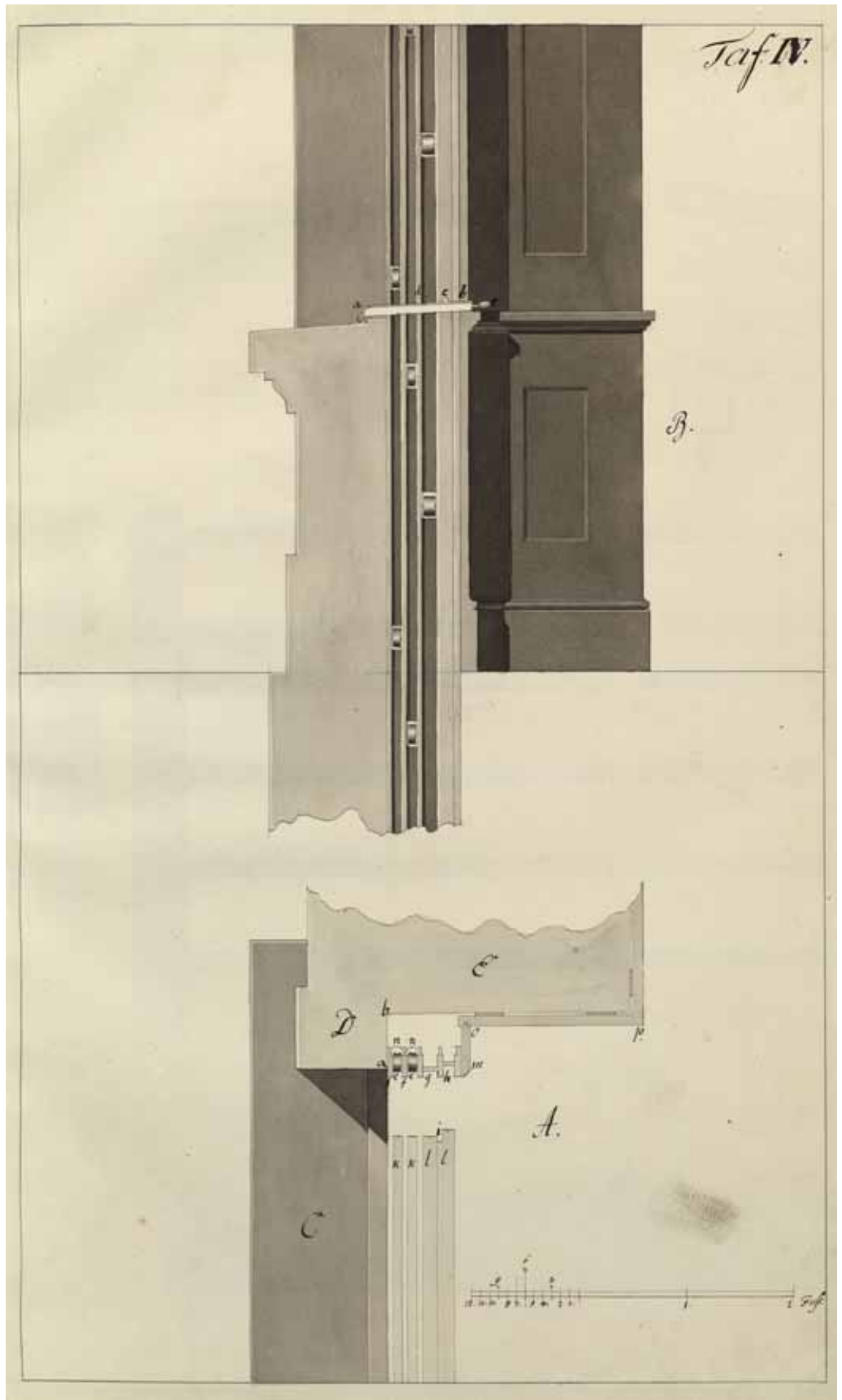

Abb. 32: Tafel IV. Detailzeichnung der in Abschnitt 2 und 3 (S. 96) beschriebenen Mechanik der versenkbaren „englischen“ Fenster. In Müllers Bauausführung wurden die heute noch vorhandenen normalen zweiflügeligen Fenster eingebaut, die allerdings beim Beobachten nicht den von Borheck gewünschten freien Ausblick gestatten. 
den im zweiten Abschnitt bemerkten Bequemlichkeiten, wegen welcher die Fensterrahmen und Laden, hinter die Brüstungsmauer müssen versenkt werden können. Dieses zu erreichen, wird Taf. III, Fig. 2 - A, von der obern Kante der Fenstersohlbank a, die Brüstungsmauer nach der Rückseite der Sohlbank, so tief nach $b$ in lothrechter Richtung aufgeführt, als die halbe Fensterhöhe beträgt, folglich kann hier die Zocke nicht mehr als 11 Zoll Breite erhalten. Die halbe Höhe der Fensterrahmen ist 6 Fuß 3 Zoll; die Brüstungsmauer a $\mathrm{C}$ ist 3 Model, oder $3 \mathrm{Fu}$ 3 Zoll hoch: es muß also die Vertiefung unterhalb des Fußbodens von $c$ bis $b$ noch 3 Fuß 6 Zoll betragen; damit unten auf das Mauerwerk, mit Leder überzogene Leisten gelegt werden können, worauf die Rahmen und Laden beim Niederlassen zu stehen kommen.

Taf. IV zeigt die ganze Vorrichtung der beweglichen Fenster und Laden im Grundriß A, und im Aufriß B nach einem grösseren Maaßstabe.

Im Grundriß, ist $C$ ein Theil der Fenstersohlbank, D das Fenstergewände, und $\mathrm{E}$ die Schmiegemauer, welche von a bis b, 6 Zoll winkelrecht zurücktritt. Hinter diesem Rückstand ab, kommen die Nuthen oder Falzen, worin die Fensterrahmen und Laden mit ihren Gegengewichten auf und nieder laufen. Für die beiden Laden, sind die Falzen e - e, jede einen Zoll breit, bestimmt; die Zwischenscheiden $f$ sind nur halb so stark, und treten einen schwachen Zoll vor der Leibung des Fensters bei a vor. $g$ und $h$, sind die beiden Falzen der Fensterrahmen; von denen $g$ für das obere Fenster, einem halben Zoll, und $\mathrm{h}$ für das untere Fenster, einem ganzen Zoll tief ist. Bei den, im Grundriß neben einander gezeichneten Laden k, und Fensterrahmen 1, siehet man, wie der untere Fensterrahm an den Seitenstücken bei i um die Scheidendicke ausgefalzt seyn muß; damit beide Rahmen dicht hinter einander schliessen.

So wohl die Fenster als Laden, hängen in Seilen mit Gegengewichten, deren Schwere mit der angehängten Last in genauem Verhältniß stehen muß: damit die Bewegung der Fenster und Laden nicht nur leicht sey, sondern diese auch in jeder beliebigen Höhe, zum Feststehen gebracht werden können. Die Rollen über welche die Seile gehen, treten dicht an die Rahmen und Laden; und dienen zugleich zur Verminderung der Friction. $\mathrm{Da}$ indessen diese Rollen, das Klemmen in den Falzen beim Auf- und Niederschieben nicht ganz verhindern würden: so sind noch besondere kleinere Frictionsrollen nöthig. Die Lage der grossen Rollen von $21 / 2$ Zoll Durchmesser, ist in den beiden Falzen $\mathrm{e}$ im Grundriß $\mathrm{A}$ angegeben; und die Halbzirkel $n$ hinter den Rollen, bedeuten die Gegengewichte, welche aus Cilindern von Bley oder Eisen bestehen können. Im Aufriß B,

sind die Rollen in den Falzen für die Fenster und Laden, nach ihren Entfernungen von einander angegeben; noch deutlicher aber fallen selbige auf Taf. VI an den im Aufriß gezeichneten Fenster, in die Augen.

Diese ganze Einrichtung - Grundriß A wird durch eine Seitenverkleidung $\mathrm{m}-0$ dem Auge entzogen. Um aber doch an den Gegengewichten und Seilen, eintretende Reparaturen vornehmen zu können, ist die Verkleidung $m-0$ nicht angenagelt, sondern an die Scheide bei $m$, mit Holzschrauben befestigt, und bei 0 mit einer Feder in einer Nuthe in der Vertäfelung $0-p$, eingelassen.

Die erste Scheide hinter der Fensterleibung bei a, wird an das Innere des Fenstergewändes, durch drei eingegossene Schrauben befestigt. An dieses Stück, werden die Rückleisten des ersten Falzes, alsdann die zweite Scheidung, und so wechselsweise bis zur letzten Scheide, welche durch die Bekleidung $m-0$ geschlossen wird, durch Holzschrauben mit einander verbunden; damit bei vorfallenden Reparaturen an den Fenstern und Laden, Stück vor Stück gelöset werden könne, ohne daß dabei etwas zu Schaden gehe.

Da diese Falze und Scheiden, auch in die vertiefte Brüstung bis auf den Boden treten müssen: so ist zu deren Anbringung unterhalb des Fußbodens, so viel freier Raum nöthig, daß sich ein Mensch bequem bewegen, und die Befestigung der verschiedenen Theile, oder des bereits zusammengesetzten Ganzen, auf besonders dazu eingemauerten Döbbeln, verrichten könne. Dieser Raum wird dadurch gewonnen, wenn die Untersatzmauer nach der vorhin bestimmten Höhe von 3 Fuß 6 Zoll, so weit von der äussern Brustmauer zurückgesetzt wird, daß ein Zwischenraum von 2 Fuß bleibt, wie Taf. III in Fig. $2-A$, vorgestellt ist. Diese Höhlung $d f$ ist oben durch die Querlager e gedeckt, welche mit Bohlen überlegt sind, die mit den Gypsboden $\mathrm{h}-\mathrm{i}$, in einer Fläche liegen. Damit die schwachen Mauern $b-c$ und $d-i$ den Seitendruck der dagegen liegenden Erde aushalten können, so sind selbige aus Quaderstücken aufgeführt.

Wenn die Fensteröffnungen ganz geschlossen werden sollen, so ruhen die unteren Laden und 
Fenster auf beweglichen Deckklappen $a-b$, Taf. IV - B. Diese Klappen bestehen aus 3/4 Zoll dicken und 12 Zoll breiten Brettern, welche zum Schutz gegen die Witterung mit Kupferblech beschlagen seyn müssen. Nach der Länge jeder Klappe, ist bei $\mathrm{C}$ eine eiserne Feder aufgeschroben, welche in eine, im untern Fensterrahmstück ausgezogene Nuthe greift: damit, wenn die Laden hinter die Brüstungsmauer versenkt, und die Fensterrahmen ohne äussern Schutz sind, der Wind das breite Fenster nicht erschüttere, und ein Geräusch veranlassen könne, wodurch der Pendelschlag der Uhren, unhörbar werden würde. Aus eben diesen Gründen ist in $d$ ein Leisten angebracht, hinter welchen das obere Fenster tritt, wenn es, einer Beobachtung wegen, nieder gelassen werden muß. Bei a hängt die Klappe mit zwei Hespen in Haken, welche hinter dem Einsatz auf der Sohlbank eingegossen sind. An der entgegengesetzten Seite, ist ein Angrif e, um die Klappe rückwärts auf die Sohlbank schlagen zu können, wenn die Laden oder Fenster, hinter die Brüstung versenkt werden sollen. Bei diesen Zurückschlagen der Klappen, zeigt sich die Zweckmässigkeit der vorspringenden FensterSohlbänke: denn ohne diesen Vorsprung, würden die Klappen kein volles Auflager erhalten, und vom Winde auf und nieder gehoben werden können; wodurch nicht nur Geräusch entstehen würde, sondern auch die Klappen und die vordere scharfe Kante der Sohlbank, beschädigt werden könnte. Die nach auswärts geneigte Lage der Klappe, ist zum Abzug des Wassers bei Schlagregen, wesentlich nothwendig: und damit hinter dem Leisten d, die Feuchtigkeiten nicht stehen bleiben, hat selbige in der Mitte einem Einschnitt, wodurch das Wasser abziehen könne; zu dessen Beförderung die Klappe, von beiden Enden gegen die Mitte, einen geringen Fall hat.

Bei den Meridian-Durchschnitten durch die Mauern, kömmt es vorzüglich auf eine dauerhafte Verbindung des Mauerwerks an; weil an diesen Stellen der Zusammenhang des Gebäudes ganz aufgehoben wird. Es sind demnach diese Durchschnitte und die vollen Mauern unter denselben, aus Quadern aufgeführt. Diese Durchschnitte nehmen in einer Höhe von 5 Fuß, vom Fußboden an gerechnet, ihren Anfang, wie in Taf. III in Fig. 2 - B,angegeben ist. Der Quader a, ist, wie eine Fenster-Sohlbank, mit einem Wasserfall versehen, um den einfallenden Regen abzuleiten. Auf dieser Sohlbank fängt der Einschnitt an, der durch die Quader $b-c-d$, welche durch die ganze Mauerdicke binden, und seitwärts bis an die Fenstergewände treten, begränzt wird.

Die Fenstergewände von 12 Fuß 3 Zoll Höhe Fig. $2-A$, konnten nicht an einem Stück angeschafft werden; sie sind also aus drei Stücken zusammengesetzt; nämlich aus einem Unterstück $\mathrm{m}$ von $6 \mathrm{Fu}$ Länge; welches mit einem eingegossenen Döbbel auf die Sohlbank versetzt, und oben mit einem versenkten Anker in die Seitenquader verankert ist. Darauf liegt ein Binder $\mathrm{n}$ von 15 Zoll hoch; und auf diesem steht das obere Gewände 0 von $5 \mathrm{Fuß}$ Länge, welches so, wie das untere, durch Döbbel und Anker befestigt ist.

Die Durchschnittsöffnungen sind durch inwendig angebrachte Thüren welche bis zu der Höhe der Dachklappen hinauf gehen, verschlossen. Um diese Vorrichtungen, und den Mechanismus zum Oeffnen und Verschliessen der geraden Mauer- und schrägen-Dacheinschnitte, im Zusammenhange erklären zu können, muß ich erst über die Construktion des Dachs einige Erläuterungen geben.

Jedes flache Dach muß, nach Verhältniß der Tiefe des Gebäudes, eine solche Neigung haben, daß das Regenwasser abziehen, und durch Rinnen abgeleitet werden könne. Bei Bestimmung dieser Neigung, muß das Materiale der Bedachung in Betracht gezogen; und selbige für ein Schieferdach grösser, als für ein Bleydach, und für dieses grösser, als für ein Kupferdach, welches die glatteste Fläche gibt, angenommen werden.

Da es nun bei diesem Gebäude auf ein möglichst flaches Dach; zugleich aber auch auf einen guten Abzug des Regenwasser ankömmt: so wird eine Kupferbedachung den Vorzug haben; und für diese ist eine Neigung des achten Theils der halben Balkenlänge hinreichend.

Dem Hauptgebälke welches über den Zimmern der fixen Instrumente 33 Fuß 6 Zoll zwischen den beiden Umfassungsmauern frei liegt, muss in sich selbst so viel Stärke gegeben werden, daß es sich nicht beugen oder brechen kann; weil wegen der durchaus freien Meridian Durchschnitte, weder unter noch oberhalb der Balken, durchlaufende Träger dürfen angeordnet werden. Es muß also auf jedem Balken ein Hängewerk errichtet, und so verbunden werden, wie der Durchschnitt des Dachs auf Taf.V, Fig. 1 zeigt. Die Hauptbalken a sind 9 Zoll breit, 11 Zoll hoch, und die Streben b, von eben der Stärke, sind auf die Hauptbalken mit doppelten Versatzungen eingesetzt, und durch eiserne Schraubenbolzen C verbunden. (Man könnte das 


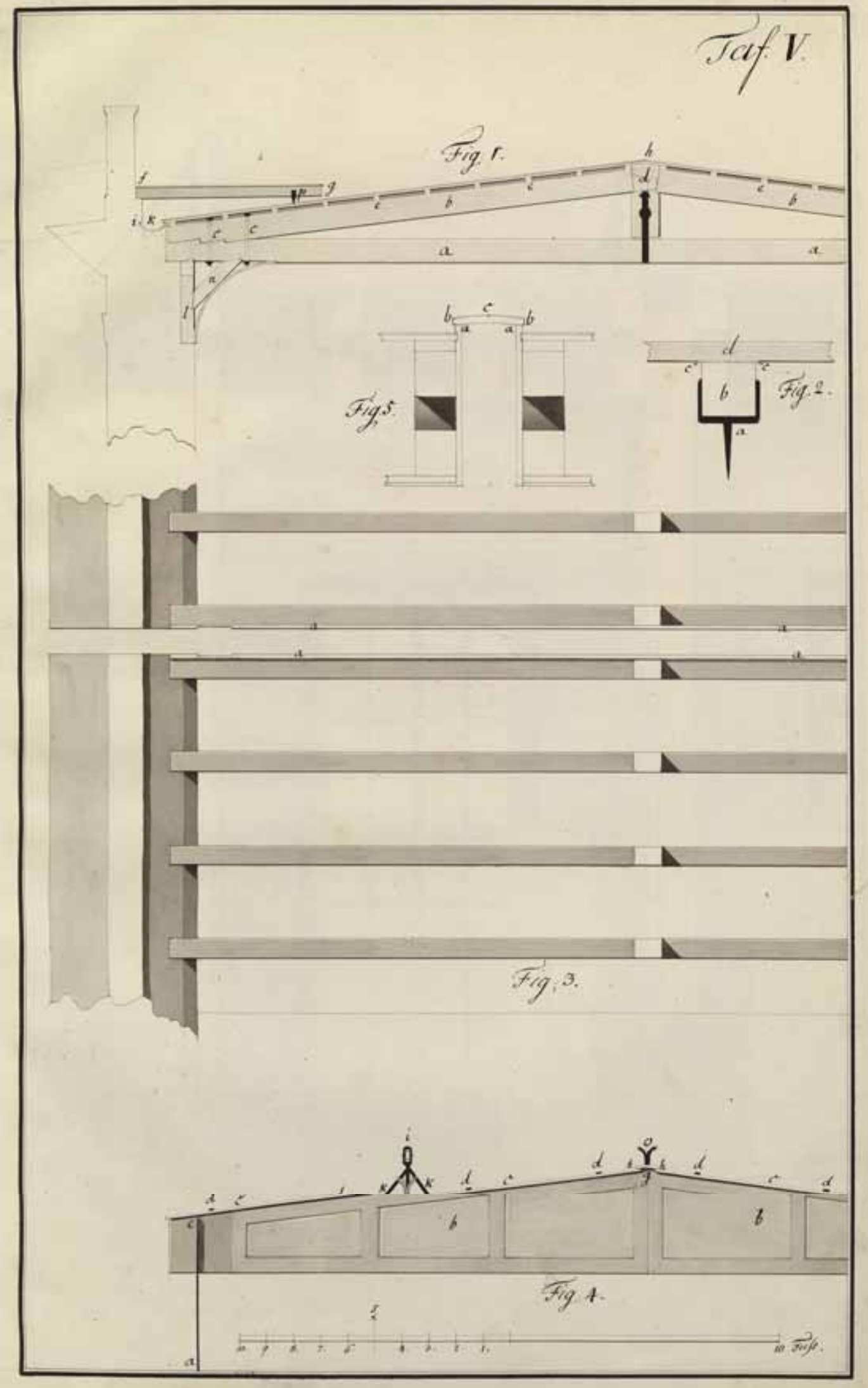

Abb. 33: Tafel V. Detailzeichnung der in Abschnitt 3 (S. 93-96) beschriebenen Konstruktion des nahezu flachen Daches, der Teilung des Daches an den Meridianspalten und deren Schließmechanismus. 
Gebälke dieser Decke noch auf andere Arten konstruiren, z.B. durch Bohlenlagen oder durch quer liegende Balken, welche zwischen diesen gehängten Balken und auf der Scheidemauer ihr sicheres Auflager erhielten. Da indessen hier nicht der Ort ist, die verschiedenen Konstruktionen frei tragender Decken zu erläutern: so gebe ich blos die bei diesem Gebäude ausgeführte Verbindung an, und überlasse es dem Ermessen eines Jeden, ob er in ähnlichen Fällen von dieser oder einer andern Anordnung, Gebrauch machen wolle.) Ueber den Streben, sind in Entfernungen von $2 \mathrm{Fuß}$ geschnittene Latten $\mathrm{C}-\mathrm{e}$ befestigt;damit die Verschaalungsdielen, nach der Länge aufgenagelt werden können: weil sie in dieser Richtung weniger dem Werfen ausgesetzt sind, als wenn sie in die quer unmittelbar auf den Streben befestigt werden. Ein zweiter Vorteil der durch diese Anordnung erhalten wird, besteht darin, daß die Hängesäulen $\mathrm{d}$ zu oberst um die Lattendicke volles Holz behalten; welches den beiden Versatzungen sehr zu statten kömmt. Die Hauptbalken und Streben, bestehen aus Tannenholz, die Säulen aber aus gesundem Eichenholz von zwölf Zoll breite und 9 Zoll Dicke: damit das Hirnholz der Steben, das Längenholz der Säulen nicht eindrücken, und ein kleines Senken verlassen könne; welches erfolgen dürfte, wenn zu den Säulen ebenfalls Tannenholz gewählt würde.

So geringe die angenommene Neigung des Dachs auch ist; indem sie mit der Horizontallinie nur einen Winkel von $7 \mathrm{Grad}$ macht: so würde selbige doch der Aufstellung beweglicher Instrumente hinderlich werden; und zwar um so mehr, da die Zusammensetzung der Kupferplatten durch Ueberfalzen geschieht, wodurch die Dachfläche uneben wird. Es muß daher über diesem Kupferdach noch ein horizontaler Fußboden angelegt werden, um die Instrumente in jeder Lage bequem gebrauchen zu können. Dieser Fußboden muß hinter der Ballustrade so weit herunter treten, als eine gewöhnliche Fensterbrüstung beträgt; damit man auf der Gränze des Dachs sicher gehen könne. Da es ohne allen Nutzen seyn würde, diesen Boden über die ganze Dachfläche fortlaufen zu lassen; weil auf demselben nur mit kleineren beweglichen Instrumenten Beobachtungen gemacht werden; indem die grösseren, wofür ohnehin die untere Terrasse bestimmt ist, zu beschwerlich hinauf zu bringen, und bei nicht ganz windstillem Wetter zu sehr Erschütterungen ausgesetzt seyn würden: so braucht derselbe nur in einer Breite von 6 bis 8 Fuß, längs der Ballustrade, angelegt zu werden, wie hier von $f$ bis $g$ geschehen ist; und der übrige Theil des Dachs, von $g$ bis zum Förstenpunkt $h$, kann frei bleiben.

Die Unterlager dieses Fußbodens, ruhen bei $f$ auf dem Quadersockel der Ballustrade, und bei $p$ in eisernen Gabeln; welche auf jeder Sparre oder Strebe, eingeschlagen werden. Die Belegung besteht aus 7 bis 8 Zoll breiten, und 11/2 Zoll dicken Dielen; wozu volle Dielen nach der Länge durchschnitten, und so neben einander gelegt sind, daß die Fugen 1/4 Zoll von einander stehen, damit der auffallende Regen durchziehen könne. Wollte man volle Dielen 14 bis 16 Zoll Breite nehmen: so würden sich diese nicht nur zu sehr werfen, und einen unebenen Boden machen; sondern es würden auch zu wenig Fugen entstehen, durch welche das Regenwasser abziehen könnte, folglich die Bedielung weit eher in Fäulung kommen. Man könnte zwar den Abzug des Wassers durch Einbohren einiger Löcher befördern; allein dadurch würden die Dielen geschwächt, und durch die rauhen Bohrlöcher die Feuchtigkeiten weit mehr in das Holz geleitet werden, als durch die geraden und glatten Fugen geschieht. Die obere Fläche des Bodens wird abgehobelt und nebst den Fugen mit gekochten Leinöhl in vier verschiedenen Zeiträumen getränkt; wodurch das Einsaugen des Regens verhütet, folglich eine längere Dauer erhalten wird.

Zur Sicherung der Unterlager gegen Fäulung müssen an den Stellen, wohin die Fugen der Dielen treffen, schmale Blechstreifen aufgenagelt werden, welche zu beiden Seiten etwas übertreten, wie Fig. 2 nach einem grössern Maaßstabe angegeben ist; wo a die Gabel, worin das Unterlager $b$ ruhet, $c$ das aufgelegte Blech, und $d$ die Dielen darstellt.

Bei der Anlage der Dachrinnen k, Fig. 1, ist die Vorsicht nöthig, selbige mit der äussern Seite, in eine in die Quader eingehauene Falz i, treten zu lassen; damit keine Feuchtigkeiten hinter der Rinne durch, bis zum Mauerwerk dringen können. Zum festen Auflager der Rinnen, werden über die Mauer Eichenbohlen gelegt, welche nach der Vertiefung der Rinnen, ausgearbeitet seyn müssen.

Die Decken der verschiedenen Zimmer, müssen zu mehrerer Zierde, als Spiegelgewölbe gebildet werden. Zu diesem Zweck, so wie zur grösseren Tragbarkeit der Hauptbalken, dienen die, in den Ecken angeordneten 8 Zoll starken Kopfbänder $\mathrm{n}$, welche so wohl Mauerwärts in die 


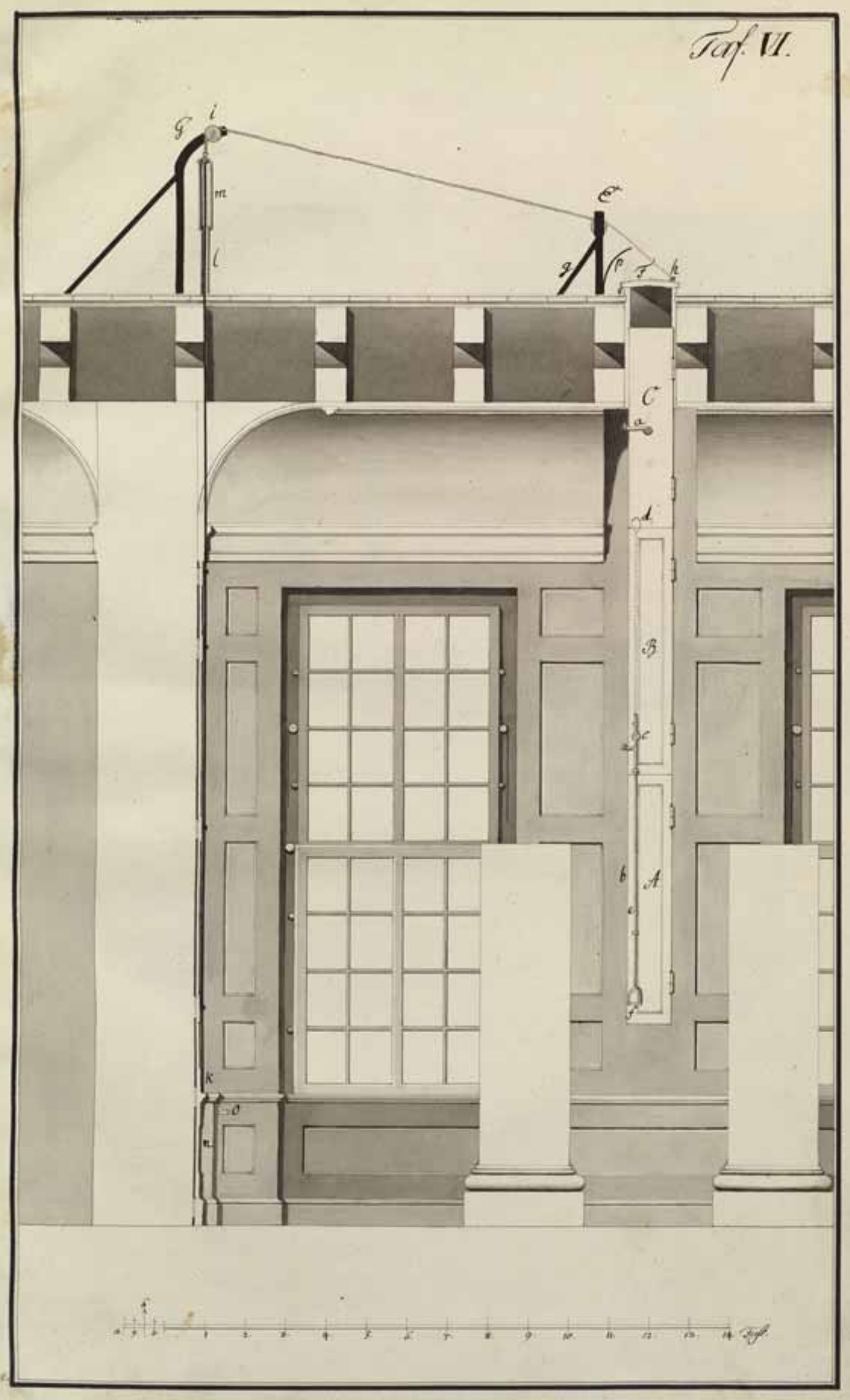

Abb. 34: Tafel VI. Detailzeichnung zur Konstruktion und Bedienung der Türen vor den Meridianspalten. 
Säulen I, als in die Hauptbalken a, mit Versatzungen eintreten. An die bündige Seite dieser Kopfbänder, werden abgerundete Bohlenstücke genagelt, und darauf die, durch doppelte Linien bezeichnete Bretter-Verschaalung, befestigt.

Bei Bestimmung der Lage und Anzahl der Hauptbalken, müssen die, zunächst den Meridian-Durchschnitten, zuerst angeordnet, und drei Zoll entfernter von einander gelegt werden, als die Weite der Durchschnittsöffnungen durch die Mauern beträgt; damit die, nach der Oeffnung gekehrten Seiten der Balken und Streben, verkleidet werden können, wie in Fig. 3 im Grundriß durch die Dielendicken $a-a$, und im Aufriß Fig. 4 durch die Vertäfelung $b-b$ angegeben ist. Diese Seitenverkleidungen müssen, zur zweckmässigen Vorrichtung der Klappen, womit die Dachöffnungen geschlossen werden, zwei Zoll über die Bedachung hinaus treten, wie der Durchschnitt Fig. 5 bei a-a zeigt. Auf diesem Vorstand a, ruhen die Deckklappen c; welche auf beiden Seiten $b-b$ etwas überstehen, auch oben abgerundet, und mit Kupferblech überzogen werden müssen, um den Regen seitwärts zu leiten. Jede Klappe C - c Fig. 4, wird mit vier langen Häspen d in Haken gehängt, welche hinter dem Vorstand auf die Sparren eingeschlagen werden.

Die Thüren zum Verschliessen der Durchschnittsöffnungen in den Umfassungsmauern, werden nach ihrer Höhe in drei Theile getheilt. Jede dieser Thüren A - B - C Taf. VI, muß für sich geöfnet werden können, je nachdem eine Observation, höher oder niedriger am Himmel, gemacht werden soll. Bei einer Beobachtung nahe am Horizont, werden die untere und mittlere Thür $A$ und $B$, und bei einer noch höheren, die obere $C$ geöfnet, und die übrigen bleiben, bei kaltem oder windigem Wetter, verschlossen: so wie sie alle drei ungeöffnet bleiben, wenn eine Beobachtung sich mehr dem Zenith nähert, wozu blos die Dachklappen aufgemacht werden.

Die obere Thür C, $5 \mathrm{Fuß}$ hoch, und wegen der Falzen 13 Zoll breit, ist dem Schlagregen am meisten ausgesetzt; und muß daher aus starken Eisenblech verfertigt werden. Sie hängt in zwei Gewinden, und hat in der Mitte ihrer Höhe, eine Federklappe a, mit der sie beim Verschliessen unter einem Klapphaken greift; beim Oeffnen aber, durch eine an der Federklappe befestigte und herabhängende seidene Schnur, nach unterwärts, und hinter dem Haken weggezogen wird.

Die beiden übrigen Thüren $B$ und $A$, jede
7 Fuß hoch 13 Zoll breit, bestehen aus Holz; und kommen mit der inneren Vertäfelung der Mauer in eine Fläche. Die untere A, hat in der Mitte bei b ein verdecktes Zugschloß, welches durch eine damit in Verbindung gebrachte Schnur, geöffnet wird; die mittlere Thür aber, wird vermittelst $A$ und $\mathrm{C}$, durch folgende Vorrichtung verschlossen gehalten.

Von der untern Kante der Thür B an gerechnet, geht durch selbige, in einer Höhe von 12 Zoll, ein Rundzapfen C. An diesem ist auf der Rückseite eine eiserne Stange befestigt; welche sich oben in einem Blechschieber d endigt, dessen Mittelzapfen hinter einem auf der obern Thür $\mathrm{C}$ befestigten Kloben greifft. Auf der Vorderseite der Thür B, steht mit dem Rundzapfen C, eine Zugstange $\mathrm{e}$ in Verbindung, welche so weit auf der Thür $A$ herunter tritt, daß der untere Angriff $\mathrm{f}$, nicht mehr als höchstens $6 \mathrm{Fu}$ vom Fußboden entfernt ist; um sie mit der Hand bequem erreichen zu können. Da diese Stange niedergezogen wird, so muß durch die Thür und Stange unmittelbar unter dem Rundzapfen, ein schmaler Einschnitt seyn, dessen Länge mit dem 4zölligen Ueberstand des Blechschiebers d, in Verhältniß steht.

Die Manipulationen beim Oeffnen und Verschliessen dieser drei Thüren, lassen sich eben so wenig beschreiben als durch Zeichnungen versinnlichen: indessen will ich doch die Ordnung der Handgriffe bemerken; und annehmen, daß die Thüren geschlossen seyn und daß sie alle drei in einem Moment geöffnet werden müßten.

In diesem Fall wird die Zugstange $f$ e $c d$ herunter gezogen, und zugleich das Zugschloß in b, und die Federklappe a, vermittelst der dazu gehörigen Schnur, geöffnet. Alsdann wird durch die zugstange, die mittlere Thür $B$ wieder dicht vor die Oeffnung gebracht, und in eben dem Augenblick die Zugstange in die Höhe geschoben; wodurch der Blechschieber $d$, hinter die obere Thür C greift, und so, mit der Thür B zugleich, auf und an die Wand zurück geschlagen werden kann. Die Thür A wird entweder mit der Schnur, oder mit der Hand, an die Mauer zurückgelegt. Soll blos die mittlere Thür B für sich allein geöffnet werden, so ist weiter nichts nöthig, als durch die Zugstange den Blechschieber d hinter der obern Thür zurück zu ziehen, und die Thür zur Seite zu schlagen. Wenn endlich die beiden untern Thüren geschlossen bleiben, und nur die obere geöffnet werden soll, so wird die Zugstange heruntergezogen, die Federklappe a gelöset, alsdenn 
mit dem Blechschieber die Thür $C$ zurückgeschlagen, und die mittlere $B$ wieder zugemacht.

$\mathrm{Zu}$ allen diesen Proceduren, wird nicht so viel Zeit erfordert, als zum Durchlesen des hierüber gesagten nöthig ist, so bald Jemand in den für jeden Fall eigenen Handgriffen gehörig geübt ist.

Die obere Blechthür $\mathrm{C}$, welche Taf. V - Fig. 4 - nach ihrer Dicke vorgestellt und mit a - e bezeichnet ist, tritt bis unter die schräge Dachklappe $\mathbf{C}-\mathrm{c}$. Diese gegenseitigen schrägen Klappen treffen am Förstenpunkt nicht unmittelbar zusammen, sondern jede ist um zwei Zoll kürzer; wodurch eine vier Zoll weite Oeffnung $g$ entsteht, die mit einer besondern kleinen Klappe $\mathrm{h}-$ $h$ von 8 Zoll Breite, unter den Nahmen Zenithklappe, bedeckt wird.

Zum Oeffnen und Verschliessen der Klappen C - C, wird nach ihrer halben Länge, hinter jeder derselben, ein aus Eisen verfertigtes Gestell i, auf die Sparren befestigt, welches aus einem aufrecht stehenden Pfosten mit drei Stützen besteht, wovon die beiden Seitenstützen mit k bezeichnet sind. Die hintere ist hier durch den geraden Pfosten gedekt; wird aber auf Taf. VI, wo bei $\mathrm{C}$ das Gestell von der Seite vorgestellt ist, in $\mathrm{g}$ sichtbar. In dieses Gestell kömmt zu oberst eine metallene Rolle, über welche eine auf der Klappe $\mathrm{F}$ in $\mathrm{h}$ befestigte Kette läuft, und von da an, über das Dach, bis zu dem Punkt $i$ fortgeleitet wird, wo in dem Zimmer in lothrechter Richtung i - k, das Oeffnen und Verschliessen der Klappe geschehen muß. Es ist daher bei $\mathrm{I}$ eine zweite Rolle, und zu dieser ein besonderes Gestell $\mathrm{G}$ nöthig.

Das Eindringen der Feuchtigkeiten in die Oeffnung, durch welche die Kette durch das Dach geht, zu verhindern, muß eine metallene Hülse oder Cylinder I, auf der Dachfläche befestigt, und durch diesem die Kette, oder besser ein Gestänge, bis in den Schlußpunkt eines zweiten Cylinders $m$, welcher sich über dem untern aufund niederschiebt, geleitet werden. Das Gestänge geht durch die Decke auf der Vertäfelung der Mauer herunter; und steht mit einer Schraube ohne Ende oder Winde $\mathrm{n}$, in Verbindung, deren Kurbel 0, vom Fußboden des Zimmers, 3 Fuß erhöht angebracht ist. Das Eisen in der Winde, muß auf zwei Fuß Länge verzahnt seyn; seine Breite kann einem Zoll und seine Dicke 3/4 Zoll betragen. Die Zähne dürfen nicht über 1/4 Zoll von einander entfernt seyn, und müssen $1 / 4$ Zoll tiefe Zwischenräume haben.

Beim Oeffnen einer Dachklappe wird an der Kurbel 0 rechts gedrehet; und dadurch das Ge- stänge mit der Kette nach unterwärts gezogen, folglich die Klappe $F$ aufgewunden. Damit aber die Klappe nicht weiter, als es die freie Durchsicht erfordert, zurückgezogen werden könne, und beim entgegengesetzten Drehen, die Klappe zum Verschliessen der Oeffnung wieder vorwärts gedrängt werde; so ist an dem Gestell $\mathrm{C}$, eine doppelarmige Stahlfeder $p$ befestigt; wodurch beide Zwecke erreicht werden.

Die Zenithklappe $h-h$, Taf. V, Fig. 4, hängt in zwei Wirbelhespen, und hat hinter sich eine besondere doppelarmige Stahlfeder $\mathrm{O}$; welche das gänzliche Zurückschlagen der Klappe verhindert, und das Vorwärtsschieben befördert. Beim Aufwinden der südlichen oder nördlichen Dachklappe, wird die Zenithklappe zugleich mit aufgehoben; und so auf jedem Fall, eine freie Durchsicht ins Zenith erhalten.

Bei der Anordnung dieser Klappen muß dahin gesehen werden, daß sie nach derjenigen Seite, woher an häufigsten Winde kommen, aufschlagen; damit das Einströhmen des Windes in die Durchschnittsöffnungen, durch die aufgestellten Klappen abgehalten werde.

Ueber die innere Einrichtung der Kuppel und Konstruktion der Marschinerie zum Drehen des Kuppeldachs, läßt sich nur alsdann etwas zuverlässiges, und für alle Fälle anwendbares sagen, wenn das für das obere Kuppelzimmer bestimmte Instrument, wirklich vorhanden ist; weil nach der Grösse seines Fußgestelles und seiner Höhe, so wohl der Pfeiler, auf welchem es ruhen muß, und die Fußbodenlage des Zimmers, als auch die, zur horizontalen Bewegung des Kuppeldachs nöthigen Maschinerien, angeordnet werden müssen. Göttingens Sternwarte kömmt einst in den Besitz des vortrefflichen zehnfüssigen Dollands, des Herrn Justizraths Schröter, welches, nach den Urtheilen aller Kenner, ein so äusserst vollkommnes Werkzeug ist, daß es einen ausgezeichneten Standpunkt verdient, der sich denn in dem obern Kuppelzimmer finden würde. Könnte ich diesen Fall bestimmt annehmen, so wäre ich im Stande nach diesem mir genau bekannten Instrument, die innere Einrichtung der Kuppel darzustellen und zu erläutern; allein dieses getraue ich mir nicht: indem sich mit der größten Wahrscheinlichkeit voraussetzen läßt, daß $\underline{\text { Sr. }}$ König1. Großbritth. Majestät die hiesige Sternwarte mit einem Aequatoreal-Sektor zu_beschenken geruhen werden, welcher alsdann, als fixes Instrument betrachtet, und in Rücksicht seines Gebrauchs, nothwendig in dem obern Kuppel- 
zimmer aufgestellt werden müßte. Aber von welcher Grösse und Beschaffenheit wird dieses Instrument seyn? Diese im voraus nicht zu beantwortende Frage, gebietet mir über die richtigen Standpunkte der Pfeiler, des Fußbodens und der Maschinerie, Stillschweigen, wenn ich mich nicht dem Vorwurf aussetzen will, etwas willkürliches angenommen und Kupfertafeln und Text auf eine unnütze Art vermehrt zu haben. Was aber im allgemeinen bei dem innern Bau der Kuppel beobachtet werden muß, besteht im folgenden.

Der erste Fußboden in der Kuppel, muß mit dem Fußboden des platten Dachs in einer Fläche liegen; um die beweglichen Instrumente mit Bequemlichkeit aus der Kuppel auf das Dach schaffen zu können. Damit aber die Instrumente nach jedesmaligen Gebrauch nicht in die unteren Zimmer, oder oben in die Kuppel, gebracht werden dürfen; weil selbige durch unbehutsames Tragen leicht Schaden nehmen könnten: so muß auf diesem ersten Kuppelboden, so viel freier Raum seyn, daß daselbst die Instrumente ihren beständigen Stand haben, und von demselben mit leichter Mühe durch die nach Süden angelegte Thür, auf das platte Dach geschafft werden können. Bei allzu windigem Wetter, da die Instrumente auf dem freien Dache einen unsicheren Stand haben würden, kann selbst von diesem Platze ab, durch die südliche Thür, und durch die nach Osten und Westen angelegten Fensteröffnungen, beobachtet werden. Zur vollkomnen Erreichung dieser Zwecke, wäre es sehr erwünscht, einen durchaus freien Raum zu haben; allein dieser läßt sich um deswillen nicht gewinnen, weil auf dieser Bodenfläche Pfeiler errichtet werden müssen, auf welchen das für die Kuppel bestimmte Instrument einen unerschütterlichen Standpunkt erhält. Diese Pfeiler müssen auf einem unwandelbaren Grunde ruhen; und da die Ruhepunkte nicht auf die Umfassungsmauern, sondern mehr nach der Mitte hintreffen: so wird es nothwendig, diesen runden Raum mit einem Gewölbe dergestalt zu schliessen, daß der Schlußpunkt die obere Fläche des Fußbodens bildet.

Kann ein solches Gewölbe nach einem halben Zirkelbogen angelegt werden, so ist es am geschicktesten die Last der Pfeiler zu tragen. Sollten aber Schwierigkeiten eintreten, welche die Anlage eines Halbzirkelgewölbes nicht gestatteten: so muß entweder ein gedruktes Bogen- oder auch ein Spiegelgewölbe gewählt werden; so wenig das letztere auch dazu geeignet ist, eine aufgesetzte Last zu tragen. Um diese Last für das Gewölbe so unschädlich wie möglich zu machen, müssen die Pfeiler aus leichten Tuftsteinen oder Mauerziegeln aufgeführt, und zu oberst mit einer Stein- oder Marmorplatte bedeckt werden, die der Grösse des Instruments, oder vielmehr dessen Fußgestelles, angemessen ist.

Bei einem Spiegelgewölbe kann der Fall eintreten, daß ein Theil der Pfeiler, auf den geraden Spiegel zu stehen kömmt. Alsdann müssen eiserne Stäbe 3 Zoll hoch und 1 1/2 Zoll breit, über das Gewölbe gelegt werden; welche nicht nur auf den Widerlagen, sondern auch auf den Umfassungsmauern ruhen; wo sie auf Quaderstücken einzulassen, und mit Querstangen zu versehen sind; wodurch sie zugleich Anker für die ganze Kuppelmauer abgeben. Daß diese Stäbe so eingelegt werden müssen daß sie auf dem Fußboden nicht sichtbar seyn, und zugleich das Gewölbe, vorzüglich aber den Spiegel, nicht unmittelbar berühren dürfen, versteht sich von selbst. 


\section{Nachschrift $^{1}$}

Im Jahre 1805, als ich diese Abhandlung nebst den nöthigen Rissen zum Druck ausgearbeitet hatte, wollte weder Herr Dieterich noch Hr. Ruprecht, den Verlag dieses Werks übernehmen; weil ich dabei die Bedingung machte, daß es in groß Folio mit lateinischen Lettern auf Schweitzerpappier gedrukt, und die Risse von guten Meistern in Kupfer gestochen werden sollten. Dieses Ablehnen war meinem Hochverehrten Freunde weyl. Geheimen Justizrath Heyne, sehr unangenehm; weil er wünschte, daß es der gelehrten Welt bekannt würde, daß in Göttingen eine, der neuen Astronomie eben so entsprechende als prachtvolle Sternwarte, aufgeführt werde, und der Grund bereits dazu gelegt sey. Er erboth sich daher, einigen Buchhändlern in Leipzig den Antrag zu machen, dieses Werk in Verlag $\mathrm{zu}$ nehmen. Ich war damit zufrieden, übergab ihm das Manuskript mit den dazu gehörigen Rissen, und reiste im Juni 1805 nach einem im Hesseschen gepachteten Landguthe ab, um meinen sehr geschwächten Augen, durch landwirthschaftliche Beschäftigungen, Erholung zu verschaffen.

Nach Verlauf von ein paar Monaten schrieb mir der würdige Mann, daß die Leipziger Buchhändler sich ebenfalls auf den Verlag dieses Werks nicht einlassen wollten; weil dazu ein beträchtlicher Vorschuß gehöre, und der Buchhandel jetzt ganz im Stocken sey. Beruhigen sie sich hierüber schrieb er, ich will ihr Mascpt. bei mir behalten, und den ersten günstigen Zeitpunkt, für ihre, und zugleich für meine Wünsche nutzen. Aber die Zeiten wurden immer ungünstiger, bis endlich der gänzliche Umsturz unserer angebohrnen Landesverfassung eintrat, und das Königreich Westphalen gegründet wurde.

${ }^{1}$ Die Nachschrift hat Borheck Ende 1812 oder 1813 verfasst.
Diese veränderten Umstände liessen mich glauben, daß der Bau der Sternwarte nie fortgesetzt werden würde, weshalb ich auf meine $\mathrm{Ab}$ handlung weit wenigern Werth legte, und sie ruhig in Heynens Händen ließ. Endlich erschien im Frühjahr 1810 ein Königl. westphl. Dekret, worin es hieß:

daß nach den Planen und Anschlage des Universitäts Baumeisters Borbeck, der Bau der neuen Sternwarten in Göttingen, ausgeführt werde etc.

und dieses verscheuchte meine bisherige Gleichgültigkeit. Ich schrieb also an Heyne und bath um die Rücksendung meiner Abhandlung, erhielt aber die unangenehme Antwort, daß er die von mir, bei meinem Abgange von Göttingen, erhaltenen officiellen Bauakten, hätte abgeben müssen, und aus Versehen auch mein Werk über die Anlage neuer Sternwarten, ausgehändigt habe, leider aber nicht bestimt sagen könne, ob das alles nach Hannover oder Cassel gekommen sey.

So mußte ich nun meine mühevolle Arbeit gleichsam als verlohren ansehen; ein Verlust, der mir weit weniger empfindlich gewesen wäre, wenn ich die Gewissheit ihrer Vernichtung gehabt hätte: aber der Gedanke, ob nicht vieleicht dieses Werk in solche Hände gekommen sey, daß davon bei der Ausführung des Baues, Gebrauch gemacht werden könne, war mir höchst unangenehm, und ließ mich die große Anstrengung meiner schwachen Augen, bei Verfertigung der feinen Riße, innigst bedauern, mußte mich darüber zufrieden geben; weil ich nicht wußte an wen ich mich deshalb wenden sollte. Zufällig machte ich im Frühjahr 1812 die Bekantschaft eines Districts-Baumeisters - Reinhold, der späterhin als Bauinspektor in Königl. Hannövr. Diensten sich durch die Schrift: Der deutsche Handels-Kanal, oder die schiffbare Verbindung der deutschen Meere u.s.w. bekant gemacht hat - der mir versicherte, daß er vor etwa zwei Jahren, im Oberbaucollegio zu Cassel, eine von mir geschriebene Abhandlung, unter dem Titel: Grundsätze über die Anlage neuer Sternwarten, nebst dazu gehörigen Planen, gesehen habe, und daß ich mich deshalb an den General-Baudirektor Joussow, wenden möge. Ich schrieb also an diesen, legte Heynens Briefe als Beweise bei, daß diese Abhandlung nicht zu meinen ehemaligen Dienstarbeiten gehöre, sondern aus einem bloßen Fehlgriff dHr. Geh. Justizraths Heyne, an das OberbauDepartement eingeliefert sey. 
Lange wartete ich auf eine Antwort aber vergebens, und reiste daher im Juni nach Cassel, um mit Hr. Staatsrath von Leist und Hr. GeneralBaudirektor Joussow, über diese Angelegenheit mündlich zu reden. Beide Herren gaben mir zu vernehmen, daß man meine Abhandlung als ein officielles Aktenstück angesehen, was sie $\mathrm{dHr}$. Professor Gaus in Göttingen zur Beurtheilung zugeschickt hätten, und da dieser seinen Beifall darüber bezeugt habe, so sey es dem DistriktsBaumeister Müller mit dem Befehl eingehändigt, nach dieser Anleitung den Bau der Sternwarte auszuführen. Ich berief mich auf Heynens Briefe, woraus klar hervorgehe, daß diese Arbeit mein privat Eigenthum sey, bath ernstlich um die Rückgabe derselben, und erhielt endlich die Versicherung, daß dem Baumeister Müller aufgegeben werden solle, das Werk zurück zu schicken. Von jetzt an sahe ich mit jeden Posttage der Ankunft meiner Arbeiten entgegen, aber leider vergeblich. Ich beschloß daher, um an die Wahrheit zu kommen nach Göttingen zu reisen, besuchte am 8ten October 1812 den Baumeister Müller, und fand auf dessen Arbeitstisch meine
Abhandlung nebst Rissen, die ich denn auch so gleich als mein Eigenthum in Besitz nahm. Herr Müller machte dagegen keine Einwendungen, sondern entschuldigte die verzögerte Aushändigung damit, daß er noch manches, den inneren Bau betreffend zu copiren und zu ercerpiren, nöthig gefunden habe.

Bei Besichtigung des in den Umfassungs- und Scheidewänden beinahe vollendeten Baues, fand ich, daß man der Hauptfassade eine andere Dekoration gegeben, die dorischen Wandpfeiler und Fenstereinfassungen weggelassen, und alles schlicht gemacht hatte. Damit nun diese aus bloßem Kunstneid gewählte Abänderung der Dauerhaftigkeit nicht schade, so hat man die ganze Vorderfacade von Sandsteinquadern aufgeführt, und den übrigen von rauhen Steinen verfertigten Umfassungsmauern, durch einem Bewurf und Anstrich mit Leimfarbe, das Ansehen von Quadermauern zu geben gesucht. Diese Abweichung von der reinen dorischen Ordnung, hat sich auch auf die beiden freien Säulen des Haupteinganges und das Kranzgesims erstreckt. Auch hat man der Treppe zur Kuppel, eine andere Lage gegeben. 


\section{Georg Heinrich Borheck}

1751 geboren in Göttingen

1771 Studium der Mathematik in Göttingen

1779* Entwurf einer Anweisung zur Landbaukunst, Teil 1

1780 Ernennung zum Klosterbaumeister für Calenberg und Göttingen sowie zum Universitäts-Baumeister, Lehrbefugnis an der Universität, Beteiligung an der Planung für eine neue Bibliothek

1784 Planung und Errichtung (bis 1787) des Accouchierhauses in Göttingen

1787 Entwurf und Bau der Michaeliskirche

1791 Erste Pläne für eine neue Sternwarte

1792* Anweisung zur Landbaukunst, Teil 2

1793 Kirchenbau in Mengershausen

1801 Pläne für einen Neubau der Bibliothek

1802 Borheck beginnt Planung der Sternwarte

1803 Baubeginn der Sternwarte

1804 Bauarbeiten an der Sternwarte eingestellt

1805 Borheck beendet Manuskript zur Sternwarte, dessen Publikation scheitert; geht wegen Augenleidens in Pension und zieht nach Wolfhagen/Hessen

1806* Anweisung über die zweckmäßige Anlegung der Landkirchen, mit $13 \mathrm{~K}$.

1807 25. Juli Berufung von C. F. Gauß

1810 Edikt Jérômes zum Weiterbau der Sternwarte nach Borhecks Plänen,

Überarbeitung der Architektur durch Jussow und Crelle, Übertragung der Bauleitung an Justus Heinrich Müller

1812 Rückgabe des Manuskripts und der Pläne zur Sternwarte an Borheck

1813 Das Gesuch Borhecks um Wiedereinstellung bleibt erfolglos

1816 Fertigstellung der Sternwarte durch Justus Heinrich Müller

1820 Borheck nimmt Lehrtätigkeit wieder auf

1822* Lehrbuch der Landbaukunst für Baumeister und Landwirthe, 2 Bde. m.K.

1826* Gründliche Anweisung zur richtigen Anlage der Beutelmaschinen und der deutschen Oelmühlen, m.K.

1834 Tod Borhecks; er hinterlässt seine Ehefrau und eine Tochter

* Publikationen Borheck

\section{Politische Ereignisse der Zeit}

1760 Georg III, König von Großbritannien und Kurfürst von Hannover, Beginn der industriellen Revolution

1776 Unabhängigkeitserklärung der USA

1781 Aufhebung der Leibeigenschaft in Österreich und in anderen deutschen Staaten

1789 Französische Revolution

1792 Frankreich erklärt Österreich den Krieg, „Marseillaise“

1799 Napoléon Bonaparte Erster Konsul

1802 Georg III bewilligt die Mittel für den Bau der Göttinger Sternwarte

1803 Franzosen besetzen Hannover

1804 Napoléon Bonaparte Kaiser der Franzosen, plant Landung in England

1805 Napoléon siegt bei Austerlitz

1806 Napoléon siegt bei Jena und Auerstedt, Herzog Ernst, Gauß’ Mäzen, stirbt, Kontinentalsperre gegen England

1807 im August Errichtung des Königreichs Westfalen unter Jérôme Bonaparte

1813 Napoléon verliert die Völkerschlacht bei Leizig, Jérôme dankt ab, Wiederherstellung der Herrschaft Georgs III

1814 Wiener Kongress, Hannover Königreich

1820 Georg IV König von Großbritannien und Hannover

1830 Wilhelm IV König von Großbritannien und Hannover

1837 Ernst August König von Hannover Amtsenthebung der Göttinger Sieben Victoria Königin von Großbritannien Preußen verbietet die Kinderarbeit 


\section{Kurzbiografien}

DAVID AUBIN, geb. 1967, "maittre de conférences" for the history of mathematical sciences am Institut de mathématiques de Jussieu, Université Pierre-et-Marie-Curie (Paris 6), Arbeitsschwerpunkte: History of Observatories, 18th-20th centuries.

Klaus Beuermann, geb. 1937, Studium der Physik und Mathematik in Kiel und Göttingen, Auslandaufenthalte California Institute of Technology und Harvard University, Professor i.R. an der Universität Göttingen. 1994 - 1996 Direktor der Universitäts-Sternwarte, 1997 - 1999 Dekan der Fakultät für Physik der Universität Göttingen. Arbeitsschwerpunkte: Kompakte Sterne, Röntgenastronomie.

ROBERT FÖRSTER, geb. 1954, Dipl.-Ing., Architekt im Universitätsbaumanagement Göttingen, Projektleiter für Universitätsbauvorhaben, Arbeitsschwerpunkte: Sanierung und Restaurierung historischer Universitätsgebäude wie Aula, Auditorium, Universitäts-Sternwarte, Heyne-Haus u.a.
Christian FreIgANG, geb. 1959, Studium von Kunstgeschichte und Klassischer Archäologie in München, Bonn und Berlin; Lehrtätigkeiten in Genf, Göttingen und Freiburg; seit 2003 Professor für Kunstgeschichte an der Johann Wolfgang Goethe-Universität Frankfurt am Main, Associate im International Center of Medieval Art, Arbeitsschwerpunkte: Geschichte der Architektur und Architekturtheorie, Bildkünste des Spätmittelalters.

NiCOLAAS RUPKE, geb. 1944, Professor und Direktor am Institut für Wissenschaftsgeschichte der Universität Göttingen. PhD Princeton 1972, Forschungsstellen u.a. an der Smithsonian Institution, Universität Oxford/UK, der Wellcome Institution/UK und dem Institute of Advanced Studies/Australien. 1997/98 Nelson O. Tyrone Jr. Professor of the History of Medicine-elect an der Vanderbilt University. Arbeitsschwerpunkte: Geschichte der Bio- und Geowissenschaften der späten Neuzeit, nationale Wissenschaftsgeschichte Deutschlands und Großbritanniens. 